Indira Alves França

\title{
Avaliação da Capes e Gestão de Programas de Excelência na Área de Educação
}

Tese de Doutorado

Tese apresentada ao Programa de Pós-Graduação em Educação da PUC-Rio como requisito parcial para obtenção do título de Doutora pelo Programa de Pós-Graduação em Educação do Departamento de Educação da PUC-Rio.

Orientadora: Profa. Alicia Bonamino 
Indira Alves França

\section{Avaliação da Capes e Gestão de Programas de Excelência na Área de Educação}

Tese apresentada ao Programa de Pós-Graduação em Educação da PUC-Rio como requisito parcial para obtenção do título de Doutora pelo Programa de Pós-Graduação em Educação do Departamento de Educação da PUC-Rio. Aprovada pela Comissão Examinadora abaixo assinada.

\section{Profa. Alicia Maria Catalano de Bonamino Orientadora Departamento de Educação - PUC-Rio}

Profa. Cynthia Paes de Carvalho Departamento de Educação - PUC-Rio

Profa. Maria Ines Galvão Flores Marcondes de Souza Departamento de Educação - PUC-Rio

Prof. José Vieira de Sousa - UNB

Prof. Robert Evan Verhine - UFBA

Profa. Denise Berruezo Portinari Coordenadora Setorial de Pós-Graduação e Pesquisa do Centro de Teologia e Ciências Humanas - PUC-Rio

Rio de Janeiro, 25 de abril de 2014. 
Todos os direitos reservados. É proibida a reprodução total ou parcial do trabalho sem autorização da universidade, da autora e do orientador.

\section{Indira Alves França}

Graduada em Pedagogia pela Universidade Federal Fluminense (2001), com especialização em Gestão Educacional pela Universidade de Taubaté (2004) e Mestre em Educação pela Pontifícia Universidade Católica do Rio de Janeiro (2007). Atuou como professora de Educação Básica e Coordenadora Pedagógica na rede municipal das cidades de Paraty e Ubatuba e foi Técnica em Assuntos Educacionais na Universidade Federal do Rio de Janeiro (UFRJ). Atualmente é servidora estatutária da Fundação Oswaldo Cruz (Fiocruz) na cidade do Rio de Janeiro e exerce o cargo de Assistente de Ensino no Instituto de Comunicação e Informação Científica e Tecnológica em Saúde (ICICT) da Fundação Oswaldo Cruz (Fiocruz), atuando no Programa de Pós-Graduação em Informação e Comunicação em Saúde (PPGICS).

Ficha Catalográfica

França, Indira Alves

Avaliação da Capes e Gestão de programa de excelência na área de educação / Indira Alves França ; orientadora: Alicia Maria Catalano de Bonamino. - 2014.

249 f. : il. ; $30 \mathrm{~cm}$

Tese (doutorado)-Pontifícia Universidade Católica do Rio de Janeiro, Departamento de Educação, 2014.

Inclui bibliografia

1. Educação - Teses. 2. Educação. 3. Pósgraduação. 4. Gestão. 5. Avaliação. 6. Capes. 7. Excelência acadêmica. I. Bonamino, Alicia. II. Pontifícia Universidade Católica do Rio de Janeiro. Departamento de Educação. III. Título. 
Dedicada ao meu filho, Eduardo, que chegou há oito meses e tornou os dias mais felizes. 


\section{Agradecimentos}

À PUC-Rio, pelos auxílios concedidos, sem os quais este trabalho não poderia ter sido realizado.

À minha orientadora, Profa. Alicia Maria Catalano de Bonamino, uma pessoa especial que, sem perder o compromisso com a pesquisa e o ensino, está atenta à dimensão pessoal de seus orientandos.

Às professoras Maria Inês Marcondes e Cynthia Paes de Carvalho, pelas preciosas contribuições nos exames de qualificação.

Aos coordenadores de programa e demais entrevistados, pela colaboração com o trabalho.

Aos colegas da Fiocruz, pelo apoio e torcida; em especial ao pessoal da área de Ensino do Icict, pela compreensão e colaboração em todos os momentos.

Aos amigos que colaboraram diretamente com esta pesquisa: Anelise Gondar, Carla Pereira, Cristina Lima e Daniel Melo.

Às pessoas que cuidaram do meu bebê para que eu pudesse escrever esta tese: Fátima Dias, Rejane Freitas e Maria do Nascimento França.

Aos meus familiares e amigos, pela torcida, apoio e carinho em todos os momentos.

Ao meu marido, Sérgio França, por seu amor e companheirismo; assim como pelo seu incentivo à realização deste trabalho.

Sem o apoio e ajuda de cada uma dessas pessoas, eu não teria conseguido. 


\section{Resumo}

Indira, Alves França; Bonamino, Alicia Maria Catalano de (orientadora). Avaliação da Capes e Gestão de Programas de Excelência na Área de Educação. Rio de Janeiro, 2014. 249 p. Tese de Doutorado Departamento de Educação, Pontifícia Universidade Católica do Rio de Janeiro.

A pesquisa aborda estratégias utilizadas no contexto da prática por coordenadores de quatro programas de excelência na Área da Educação (PUCRS, Uerj, UFMG e Unisinos), que avançaram duas notas entre as avaliações trienais da Capes de 2001 e 2010. O objetivo geral da pesquisa é compreender como se caracteriza a relação entre "excelência" e "gestão" nos quatro programas, com ênfase nas estratégias acionadas pelos seus coordenadores visando ao alcance dessa condição. Na metodologia, adotamos uma abordagem qualitativa, com o estudo de caso das quatro experiências institucionais à luz, principalmente, das contribuições teóricas e metodológicas de Pierre Bourdieu e de Stephen Ball. A abordagem do ciclo de políticas de Ball permitiu, junto com o conceito de performatividade, fazer a ponte entre os níveis macro de definição das políticas para a área da pós-graduação e o nível micro da aplicação local, por meio da análise comparativa tanto dos discursos e das práticas dos atores nos programas pesquisados (estudos de caso) quanto dos resultados obtidos. A descrição, análise e comparação dos diferentes aspectos relacionados à gestão foram feitas em quatro níveis, a saber: os contextos de influência, de produção de texto, da prática e dos resultados. O quadro teórico e conceitual para o estudo e interpretação das políticas e da gestão da pós-graduação em Educação foi construído, fundamentalmente, em diálogo com Bourdieu, notadamente com o conceito de "campo científico", que rompe com a imagem ingênua de ciência, e permite entender a área da Educação e os próprios programas de pós-graduação como um campo social, com formas específicas de relações de força e monopólio, lutas e estratégias, interesses e lucros. Os principais achados da pesquisa mostraram que determinadas dimensões contextuais fazem diferença na atuação dos gestores, tais como a forma de provimento do cargo, a preparação e a remuneração que os coordenadores recebem para exercê-lo, bem como o apoio técnico-administrativo 
disponível. A análise comparativa das estratégias adotadas nos programas e as categorias nativas surgidas das entrevistas com os coordenadores revelaram aspectos coincidentes, relativos a questões como a gestão coletiva dos programas, a existência de uma política efetiva de credenciamento de docentes, um maior rigor com os prazos para titulação dos discentes, a importância dada à vinculação do projeto do candidato ao mestrado ou doutorado com a pesquisa dos docentes do Programa como crivo de seleção e uma diversidade de estratégias pedagógicas para melhoria da produção discente. Essas estratégias revelam a importância do papel dos coordenadores no alcance das notas que qualificam os programas estudados como programas de excelência. A análise do contexto dos resultados nos permitiu, finalmente, observar como a posição de excelência trouxe aos programas lucros simbólicos e materiais, como uma maior visibilidade acadêmica e um maior acesso a recursos financeiros, embora à custa de um aumento significativo do trabalho tanto da coordenação como do corpo docente. As conclusões abrangem os diferentes contextos estudados e põem em evidência as principais características das gestões dos programas que explicam as convergências e divergências detectadas. Diante dos achados da pesquisa, esperamos que este trabalho possa ir ao encontro do objetivo expresso no Documento de Área da Educação 2013, segundo o qual, é “necessário produzir indicadores que permitam diagnosticar as condições de gestão que produziriam melhor desenvolvimento do Programa e, assim, orientar mais precisamente as Instituições quanto a este aspecto".

\section{Palavras-chave}

Educação; pós-graduação; gestão; avaliação; Capes; excelência acadêmica. 


\section{Abstract}

Indira, Alves França; Bonamino, Alicia Maria Catalano de (Advisor). The evaluation of Capes and the governance programs of excellence in the Area of Education. Rio de Janeiro, 2014. 249 p. Doctoral Thesis Departamento de Educação, Pontifícia Universidade Católica do Rio de Janeiro.

The research project presents practical strategies undertaken by coordinators of four excellence programs in the field of Education (Pontifical University of Rio Grande do Sul - PUCRS, Rio de Janeiro State University - Uerj, Federal University of Minas Gerais - UFMG and Unisinos) whose programs achieved higher scores when comparing the triennial reviews held by the Coordination for Improvement of Higher Education Personell - CAPES in the years of 2001 and 2010.The general aim of this research is to understand how the relation between "excellence" and "management" is characterized in the four programs, with emphasis on the strategies implemented by their coordinators with the with the aim of reaching that condition. Qualitative methodology was chosen to approach case studies of four institutional experiences mainly in the light of the theoretical and methodological contributions of Pierre Bourdieu and Stephen Ball. Ball's policy cycle approach associated to the concept of performitivity seeks to build a bridge between macro-level of policy definition for Graduation and local application at micro-level through comparative analyses of discourses and pratices of actors involved in the programs as well as its outcomes. The description, analysis and comparison of different aspects related to management was carried through at four levels: the contexts of influence, of policy text production, of practice and of outcomes. The theoretical and conceptual framework for the analysis of Graduate course management policies was built, fundamentally in accordance with Bourdieu, notably with his concept of "scientific field". $\mathrm{He}$ proposes breaking with the naïve idea of Science and allows us to see the field of education and Graduate programs as a social field, with specific forms of power and monopoly, struggles and strategies, interests and benefits. Main findings indicate that certain contextual dimensions are relevant for the work of coordinators such as the achievement of their position, their preparation and 
payment as well as the technical and managerial support available to them. The comparative analysis of strategies adopted in the programs and native categories that emerged during the interviews show similar aspects related to issues such as the joint management of programs, effective accreditation of faculty members, a higher degree of rigor in deadlines for students, the importance of the existence of masters' or doctoral projects more closely related to the research conducted by faculty members as one of the elements for the selection of candidates. Further, the diversity of pedagogical strategies to increase students'production reveal the relevance of the role of coordinators in the attainment of grades that qualify the analyzed programs as excellence programs. The analysis of the context of outcomes permitted us to realize how a new position "of excellence" ended up bringing symbolic and material benefits, such as greater academic exposure and greater access to financial grants, although to the cost of increasing working loads for the coordination as well as for faculty members. Concluding remarks point to various contexts taken into account and highlight the main features of Graduate course management models that explain the detected convergences and divergences. We hope our findings will meet the objectives expressed in the “Documento de Área da Educação 2013"which states that "there is need to produce indicators that provide the diagnosis of management conditions so as to produce a better development of programs, thus, offering a better guidance to institutions regarding this matter."

\section{Keywords}

Education; graduate programs; management; evaluation; Capes; academic excellence. 


\section{Sumário}

1. Introdução

2. Referências teóricas e metodológicas 28

2.1. O escopo da pesquisa 28

2.2. Contribuições de Stephen Ball ao estudo 34

2.2.1. A abordagem do ciclo de políticas 35

2.2.2. O conceito de performatividade $\quad 40$

2.3. Contribuições de Bourdieu ao estudo 44

2.3.1. O campo científico 46

3. Histórico da Pós-Graduação no país 51

3.1. Notas sobre a origem e o desenvolvimento da pós-graduação 52 no Brasil

3.2. Os Planos Nacionais de Pós-Graduação: do I ao IV PNPG 59

3.2.1. I Plano Nacional de Pós-Graduação (1975/1979) 61

3.2.2. II Plano Nacional de Pós-Graduação (1982/1985) 63

3.2.3. III Plano Nacional de Pós-Graduação (1986/1989) 65

3.2.4. IV Plano Nacional de Pós-Graduação 67

4. Política de Pós-Graduação: influências internacionais e nacionais 70 reveladas no contexto de produção de texto

4.1. Contextos de influência internacional: influências históricas, 70 político-econômicas e educacionais na pós-graduação brasileira

4.2. Contexto de influência nacional: a Capes, a avaliação e 079 Sistema Qualis

4.2.1. A influência da Capes no contexto nacional de pós- 80 graduação

4.2.2. A Avaliação da Capes no novo modelo 82

4.2.3. O Sistema Qualis $\quad 84$

4.2.4. Críticas na literatura acadêmica em relação à Avaliação da 90 


\section{Capes}

4.3. Contexto da produção de texto: PNPG recentes e os 95 Documentos de Área da Educação

4.3.1. Os Planos Nacionais de Pós-Graduação mais recentes: 96 PNPG 2005/2010 e PNPG 2010/2020

4.3.2. A Área da Educação, a Grande Área de Ciências Humanas e 103 os Documentos de Área

5. Contexto da prática: relação dos coordenadores com a política 112

5.1. Relação dos agentes com a Avaliação da Capes 113

5.2. Dimensões contextuais da gestão nos programas 125

5.2.1. Provimento ao cargo de coordenador do programa 126

5.2.2. Remuneração financeira para o exercício do cargo 129

5.2.3. Preparação para atuar na função 133

5.2.4. Apoio técnico-administrativo 135

5.3. Estratégias adotadas pelos coordenadores de programas 137

5.3.1. Estratégias de gestão coletiva dos programas 137

5.3.2. Estratégias adotadas junto ao corpo docente 146

5.3.3. Estratégias adotadas junto ao corpo discente 156

6. Considerações sobre o contexto da prática à luz de Pierre 160 Bourdieu e Stephen Ball

6.1. Stephen Ball: o contexto da prática e a cultura da 161 performatividade

6.2. Pierre Bourdieu e as lutas concorrenciais no campo científico 174

7. Contexto dos resultados ou efeitos para os programas 185

7.1. Mudanças nos dados dos programas 185

7.2. Efeitos materiais e simbólicos e o aumento das demandas de 196 trabalho

7.3. Considerações sobre os efeitos na perspectiva de Ball e 201 Bourdieu 
9. Referências Bibliográficas

10. Anexos 227

Anexo 1 - Roteiro de entrevista com coordenadores de curso $\quad 227$

Anexo 2 - Exemplo de entrevista com coordenador de curso 230

Anexo 3 - Quadro de pesos por área do conhecimento e nível - $\quad 249$ Proap 


\section{Lista de quadros}

Quadro 1: Crescimento dos programas da Área da Educação 200018 $-2014$

Quadro 2: Notas dos Programas de Excelência na Área da 29 Educação - avaliações trienais 2001-2010

Quadro 3: Entrevistas realizadas na pesquisa 32

Quadro 4: Características formais dos Planos Nacionais de Pós- 60 Graduação

Quadro 5: Proporcionalidade de Programas de Excelência na Área 107 da Educação nas avaliações trienais (2001 a 2013)

Quadro 6: Evolução dos quesitos das Fichas de Avaliação da Área 108 da Educação nas avaliações trienais (2001 a 2013)

Quadro 7: Dados relativos à formação e produção intelectual dos 187 discentes nos Programas analisados (triênios 2004 a 2010)

Quadro 8: Publicação dos docentes permanentes nos Programas 191 analisados (triênios 2004 a 2010)

Quadro 9: Produção docente em periódicos Internacionais A e B 194 por triênio (2001 a 2007)

Quadro 10: Produção docente em periódicos A1 e A2 (triênio 2010) 195 


\section{Lista de gráficos}

Gráfico 1: Alunos titulados na Área da Educação 1998 - $2010 \quad 19$

Gráfico 2: Distribuição dos programas da Área de Educação por 20 região

Gráfico 3: Distribuição dos programas pelas notas (avaliação trienal 21 2013)

Gráfico 4: Evolução dos quesitos das Fichas de Avaliação da Área 108 da Educação nas avaliações trienais (2001 a 2013) 


\section{Lista de siglas}

Anped - Associação Nacional de Pós-Graduação e Pesquisa em Educação

BNDES - Banco Nacional de Desenvolvimento Econômico e Social

Capes - Coordenação de Aperfeiçoamento de Pessoal de Nível Superior

CBPE - Centro Brasileiro de Pesquisa Educacional

CFE - Conselho Federal de Educação

CLT - Consolidação das Leis Trabalhistas

CNE - Conselho Nacional de Educação

CNPq - Conselho Nacional de Desenvolvimento Científico e Tecnológico

CTC - Conselho Técnico Científico

CT\&I - Ciência, Tecnologia e Inovação

DS - Demanda Social

Faperj - Fundação de Amparo à Pesquisa do Estado do Rio de Janeiro

FMI - Fundo Monetário Internacional

Finep - Financiadora de Estudos e Projetos

Forpred - Fórum Nacional de Coordenadores de Programas de PósGraduação em Educação da Anped

Foprop - Fórum Nacional de Pró-Reitores de Pesquisa e Pós-Graduação das IES Brasileiras

FG - Função Gratificada

GACH - Grande Área de Ciências Humanas

GTRU - Grupo de Trabalho da Reforma Universitária

IES - Instituição de Ensino Superior

Inep - Instituto Nacional de Estudos e Pesquisas Educacionais Anísio

Teixeira

LDB - Lei de Diretrizes e Bases da Educação Nacional

MCT - Ministério da Ciência e Tecnologia

MEC - Ministério da Educação

OCDE - Organização para a Cooperação e Desenvolvimento Econômico

OMC - Organização Mundial do Comércio

PNPG - Plano Nacional de Pós-Graduação 
PPFH - Programa de Políticas Públicas e Formação Humana

Preal - Programa de Reforma da Educação para a América Latina

Proap - Programa de Apoio à Pós-Graduação

Proex - Programa de Excelência Acadêmica

Proped - Programa de Pós-Graduação em Educação da Uerj

SBPC - Sociedade Brasileira para o Progresso da Ciência

SNCT - Sistema Nacional de Ciência e Tecnologia

SNPG - Sistema Nacional de Pós-Graduação

TCU - Tribunal de Contas da União

UAPPG - Unidade Acadêmica de Pesquisa e Pós-Graduação

Unesco - Organização das Nações Unidas para a Educação, a Ciência e a Cultura 
Na verdade, é muito sedutora a proposta de se ter um "envolvimento apaixonado na medida certa" no que diz respeito à excelência, a atingir o "máximo desempenho", a ser o "melhor", a alcançar a mais alta classificação do ensino ou da pesquisa, a obter pontos por reconhecimento ou uma condição especial [...] Mas o que está ocorrendo é que a complexidade humana vê-se reduzida à forma mais simples possível: números em uma tabela.

Stephen Ball 


\section{1.}

\section{Introdução}

A área de pós-graduação, locus privilegiado de formação do pesquisador e da produção do conhecimento no país, tem apresentado forte crescimento nos últimos anos. Segundo o Plano Nacional de Pós-Graduação (PNPG) 2011-2020, entre 2004 e 2009, houve um aumento de 35,9\% no número de cursos de mestrado, de 34,4\% nos cursos de doutorado e de 104,2\% nos cursos de mestrado profissional (BRASIL, 2010). A previsão oficial é que esse crescimento deverá continuar, uma vez que o sistema brasileiro de pós-graduação ainda não teria chegado ao ponto de saturação, devendo ser convocado para novos desafios envolvendo o desenvolvimento da ciência, da tecnologia e da inovação.

Em particular, a Área de Educação, na Coordenação de Aperfeiçoamento de Pessoal de Nível Superior (Capes), é hoje uma das mais numerosas, sendo integrada por 153 programas, dos quais 62 oferecem cursos de mestrado e doutorado, 62 programas oferecem apenas cursos de mestrado acadêmico e 29 cursos de mestrado profissional. Assim, há um total de 215 cursos, sendo 62 de doutorado, 124 de mestrado acadêmico e 29 de mestrado profissional ${ }^{1}$. O quadro

1, mostra o crescimento do número de programas na Área nos últimos 14 anos.

\section{Quadro 1: Crescimento dos programas da Área da Educação 2000 - 2014}

\begin{tabular}{|c|c|c|}
\hline Ano & Programas & \% Crescimento \\
\hline 2000 & 54 & - \\
\hline 2003 & 68 & $26 \%$ \\
\hline 2006 & 78 & $15 \%$ \\
\hline 2009 & 93 & $19 \%$ \\
\hline 2011 & 113 & $22 \%$ \\
\hline 2014 & 153 & $35 \%$ \\
\hline
\end{tabular}

Fonte: Capes, 2014.

\footnotetext{
${ }^{1}$ Fonte: Capes. Disponível em: < http://conteudoweb.capes.gov.br/conteudoweb/ProjetoRelacao CursosServlet?acao=pesquisarArea\&identificador=38\#>. Acesso em: 24 fev. 2014.
} 
Observando o quadro 1, percebe-se um crescimento sustentado do número de programas ao longo do tempo, que fez com que a Área praticamente triplicasse seu tamanho entre 2000 e 2014.

Paralelamente ao crescimento no número de programas da Área, houve um aumento praticamente equivalente na titulação de mestres e doutores, como mostra o gráfico $1^{2}$.

\section{Gráfico 1: Alunos titulados na Área da Educação 1998 - 2010}

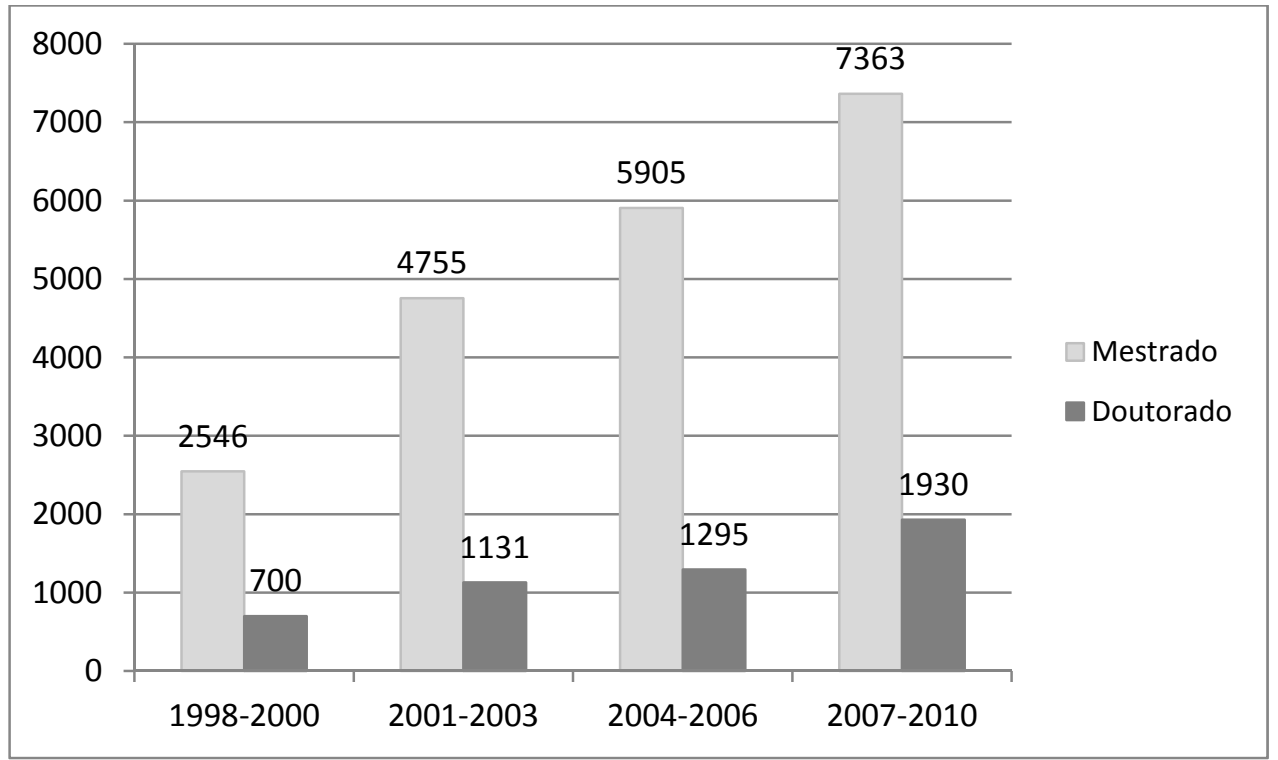

Fonte: Capes, 2011.

No gráfico 1 observamos que o número de mestres titulados nos triênios considerados praticamente triplicou, passando de 2.546, em 1998/2000 para 7.363, em 2007/2010, o que representa um aumento de 189\% ao longo de uma década. No doutorado, o crescimento também foi expressivo, passando de 700 doutores titulados no triênio 1998/2000 para 1.930 no triênio 2007/2010, com um crescimento de $176 \%$. O gráfico não apresenta dados sobre o mestrado profissional por duas razões: essa modalidade de cursos foi criada recentemente e, até 2010, ainda não havia titulado nenhum mestre.

\footnotetext{
${ }^{2}$ O gráfico 1 é parte integrante da apresentação da representante de Área no Conselho Superior da Capes, realizada em 12/07/2011 e disponibilizada na página da Área da Educação, no site da Capes.
} 
O gráfico 2, por sua vez, mostra a distribuição regional dos programas de pós-graduação da Área da Educação.

\section{Gráfico 2: Distribuição dos programas da Área de Educação por região}

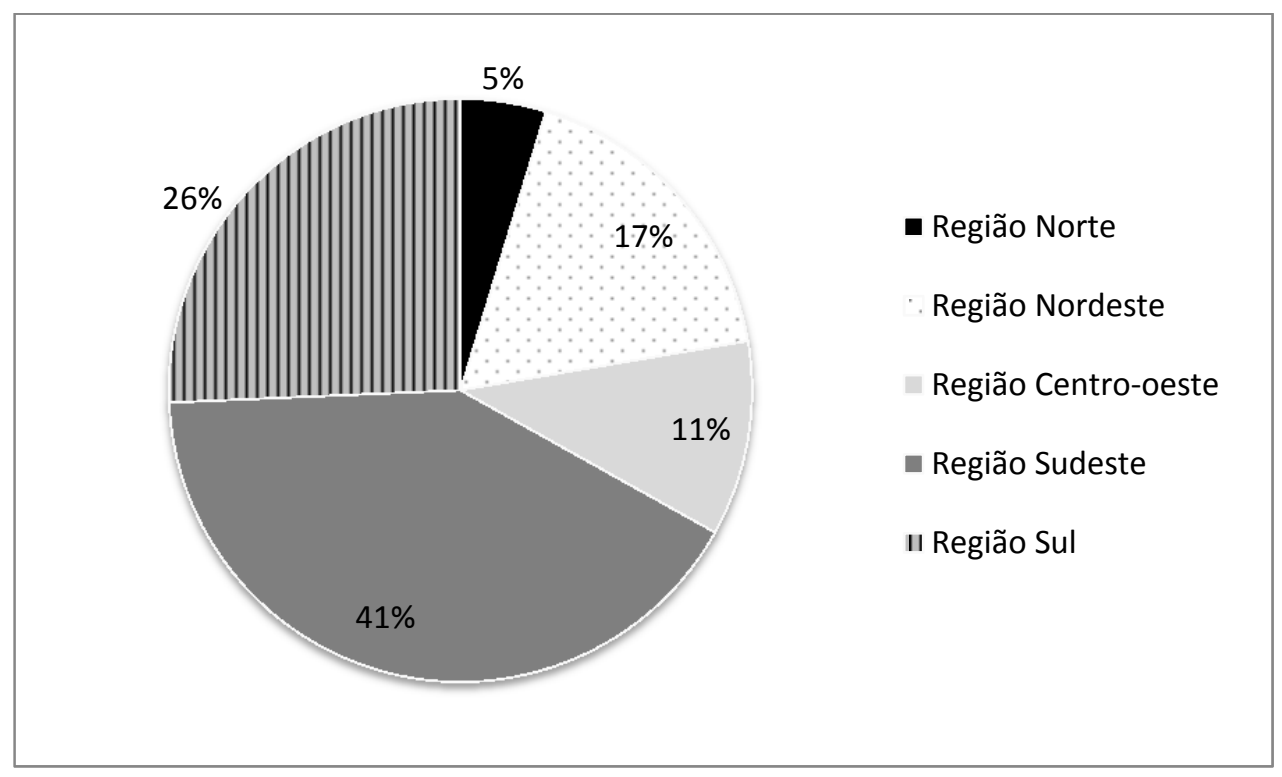

Fonte: Capes, 2014.

Observamos neste gráfico que os programas da Área não estão equilibradamente distribuídos pelas diferentes regiões do país, uma vez que a maior parte deles está concentrada nas regiões Sudeste e Sul. Este não é problema novo nem atinge apenas a Área da Educação. Os primeiros planos nacionais de pós-graduação já apontavam a assimetria na distribuição dos cursos e programas de pós-graduação entre as regiões do país como um problema a ser enfrentado.

O gráfico 3, por sua vez, mostra a distribuição das notas dos programas. O que vemos no gráfico 3 é uma maior concentração na nota 4 (41\%), seguida dos programas de nota 3 (38\%) e nota 5 (14\%). Os Programas de Excelência constituem $7 \%$ do total, sendo $5 \%$ deles com nota 6 e $2 \%$ com nota 7 . 


\section{Gráfico 3: Distribuição dos programas pelas notas (avaliação trienal 2013)}

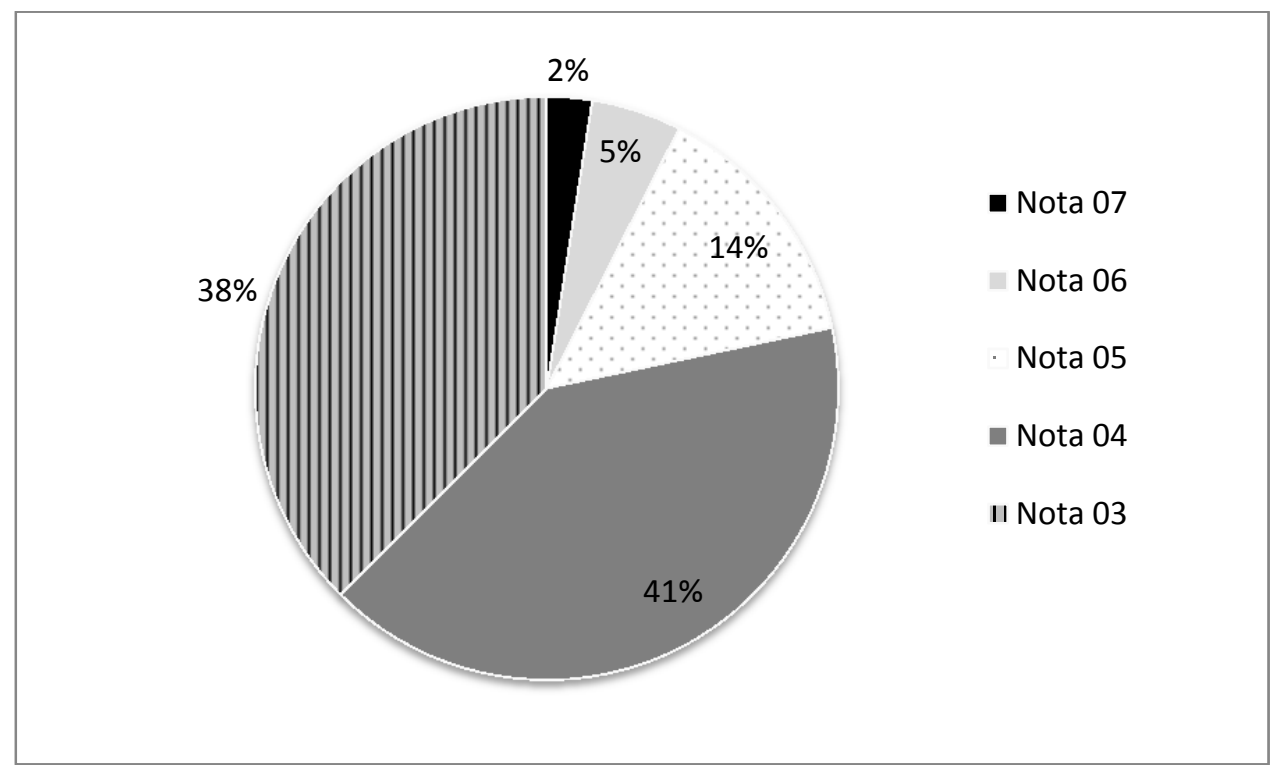

Fonte: Capes 2013. Elaboração da autora, com base nas 120 notas da Área de Educação disponibilizadas pela Capes na planilha de avaliação trienal.

A Área da Educação vem se consolidando ao longo dos anos. De acordo com Documento de Área 2013 (CAPES, 2013a) houve um crescimento do índice de produção bibliográfica em periódicos e livros e a publicação em periódicos científicos nacionais ampliou-se em três vezes, o que coloca, para o próximo triênio, o objetivo de consolidar esses avanços. O mesmo documento também indica que outro desafio da Área para os próximos anos será o de criar indicadores que permitam avaliar a gestão dos programas. É a Capes reconhecendo que as atividades de gestão precisam ser mais bem orientadas, a partir da produção de indicadores.

\footnotetext{
Um outro aspecto a ser aperfeiçoado diz respeito à gestão de Programas. Será necessário produzir indicadores que permitam diagnosticar as condições de gestão que produziriam melhor desenvolvimento do Programa e, assim, orientar mais precisamente às Instituições quanto a este aspecto. (CAPES, 2013, p. 05).
}

Por sua vez, a literatura sobre a pós-graduação, apesar de identificar a gestão como uma atividade fundamental dos programas em face das avaliações da 
Capes e de sua política de financiamento, registra que raramente ela tem sido, entre nós, objeto de estudo (ALMEIDA, 2001).

Nesse contexto, nos apoiamos em indicadores e documentos produzidos no âmbito da Capes e da Área de Educação, e também nas principais, e escassas, referências da literatura sobre a pós-graduação em educação no Brasil, para desenvolver a nossa pesquisa que tem como objeto a gestão de programas de pósgraduação em educação considerados de excelência.

No conjunto dos programas que obtiveram, entre 2001 e 2010, as notas 6 e 7 nas avaliações trienais da Capes, selecionamos para estudo aqueles que conseguiram avançar de nota duas vezes ao longo dos triênios de 2001-2003, 2004-2006 e 2007-2009 e que foram considerados programas "de excelência”, pela avaliação trienal 2010, correspondente ao período 2007-2009. São eles: o Programa de Pós-Graduação em Educação da Pontifícia Universidade Católica do Rio Grande do Sul (PUCRS), o Programa de Pós-Graduação em Educação da Universidade Estadual do Rio de Janeiro (Uerj), o Programa de Pós-Graduação Conhecimento e Inclusão Social em Educação da Universidade Federal de Minas Gerais (UFMG), e o Programa de Pós-Graduação em Educação da Universidade do Vale do Rio dos Sinos (Unisinos).

O objetivo geral da pesquisa é compreender como se caracteriza a relação entre “excelência” e "gestão” em cada um desses quatro programas, com ênfase nas estratégias acionadas pelos seus coordenadores visando ao alcance dessa condição. Nesse sentido, a pergunta que nos guia em relação ao cumprimento desse objetivo é a seguinte: Quais as estratégias adotadas pelos gestores dos programas de excelência investigados, entre 2001-2010, que podem ter contribuído para o alcance dessa condição?

O Programa de Pós-Graduação em Educação da PUCRS funciona em uma Universidade confessional católica e comunitária que está entre as mais tradicionais instituições privadas de ensino superior do Brasil. A instituição é formada fisicamente pelo Campus Central, em Porto Alegre, capital do Rio Grande do Sul, e por outras duas unidades, uma no município de Uruguaiana, no interior do estado, e outra em Viamão, na região metropolitana. O Programa de Pós-Graduação em Educação está situado no Campus Central e teve início em 1972, com o curso de mestrado, que foi credenciado pelo Conselho Federal de 
Educação em 1976. O curso de doutorado foi criado em 1988 e credenciado em 1995. Atualmente, está estruturado em três linhas de pesquisa: "Pessoa e Educação”; “Formação, Política e Práticas em Educação”; e “Teorias e Culturas em Educação". Trata-se de um programa de pequeno porte, atualmente constituído por 17 professores, em regime de contratação pela Consolidação das Leis Trabalhistas (CLT) e 107 alunos. Além dos alunos pagantes, o Programa ainda oferece duas modalidades de bolsas: bolsa parcial, em que o aluno é isento das taxas e pode trabalhar, e bolsa integral, concedida a alunos que devem se dedicar exclusivamente ao curso.

O Programa de Pós-Graduação em Educação da Universidade do Vale do Rio dos Sinos (Unisinos) também funciona em uma Universidade confessional no Sul do país localizada no município de São Leopoldo, vizinho à cidade de Porto Alegre. Por sua vez, a Unisinos iniciou o curso de mestrado em 1994 e o curso de doutorado em 1999. Trata-se, também, de um curso de pequeno porte, atualmente constituído por 16 professores, em regime de contratação pela Consolidação das Leis Trabalhistas (CLT), e cerca de 120 alunos, entre os quais existem alunos pagantes, alunos que recebem bolsa parcial ou integral da Universidade e alunos que recebem bolsas das agências de fomento, como Capes e CNPq. O Programa possui as seguintes linhas de pesquisa: "Educação, História e Políticas”; "Formação de Professores, Currículo e Práticas Pedagógicas”; e “Educação, Desenvolvimento e Tecnologias”. A Unisinos ainda possui outro programa na Área da Educação, na modalidade mestrado profissional: o "Programa de PósGraduação em Gestão Educacional”, com nota 4 pela Capes.

O terceiro Programa está localizado na região Sudeste, na Universidade Estadual do Rio de Janeiro (Uerj). A Uerj é uma das mais tradicionais Universidades públicas do Estado do Rio. Seu Programa de Pós-Graduação em Educação (Proped) iniciou as atividades com o curso de mestrado, em 1979, sendo que o curso de doutorado teve início em 2002. O Programa tem porte médio e, no período em que foi realizada a pesquisa, contava com 37 professores concursados (servidores públicos) ${ }^{3}$ e uma média de 200 alunos $^{4}$. O curso se organiza em cinco linhas de pesquisa: "Cotidiano, redes educativas e processos culturais”; “Currículo: sujeitos, conhecimento e cultura”; “Educação Inclusiva e

\footnotetext{
${ }^{3}$ Fonte: site do programa. Disponível em: <http://www.proped.pro.br/>_Acesso em: 10 dez. 2013.

${ }^{4}$ Fonte: entrevista Coordenador A - Uerj.
} 
processos educacionais”, "Infância, juventude e educação”; e "Instituições, práticas educativas e história”. Sendo uma instituição pública, seus cursos de mestrado e doutorado são gratuitos e parte dos alunos recebe bolsas das agências de fomento. A Uerj possui ainda outros Programa na Área da Educação, que oferecem cursos na modalidade mestrado acadêmico: o "Programa de PósGraduação em Educação, Cultura e Comunicação" e o "Programa de PósGraduação em Educação - Processos Formativos e Desigualdades Sociais”, ambos com nota 3 pela Capes.

Por fim, o maior Programa pesquisado é o da Universidade Federal de Minas Gerais (UFMG), com média de 90 professores e 450 alunos $^{5}$. O Programa de Pós-Graduação “Conhecimento e Inclusão Social em Educação” iniciou-se em 1972, com o curso de mestrado. Em 1991, foi instituído o doutorado. Atualmente, conta com 9 linhas de pesquisa: "Educação e Ciências"; "Educação e Linguagem”; “Educação Escolar”; “Educação Matemática”; “Educação, Cultura, Movimentos Sociais e Ações Coletivas”; "História da Educação”; "Política, Trabalho e Formação Humana”; "Políticas Públicas e Educação: Formulação, Implementação e Avaliação”; "Psicologia, Psicanálise e Educação”. Por ser uma instituição federal, seus cursos de mestrado e doutorado são gratuitos e alguns alunos recebem bolsas das agencias de fomento. A UFMG possui outro Programa na Área da Educação, na modalidade mestrado acadêmico: o "Programa de PósGraduação em Educação e Docência”, vinculado ao Centro de Ensino de Ciências e Matemática, com nota 5 pela Capes.

Embora esta pesquisa, por questões de $\operatorname{prazo}^{6}$, não tenha podido contemplar a avaliação trienal 2013 (2010-2012), é interessante apontar que os programas selecionados para estudo mantiveram-se, nessa avaliação, no grupo dos Programas de Excelência: os Programa da Uerj e da UFMG com nota 7; o Programa da PUCRS, com nota 6, tendo o Programa da Unisinos passado de 6 para 7 em 2013 e, portanto, alcançado a nota máxima. Isso denota que os programas conseguiram desenvolver estratégias para continuar a atender as exigências da Capes e para manter sua posição de destaque na Área, dentro do grupo bastante restrito dos Programas de Excelência.

\footnotetext{
${ }^{5}$ Fonte: Entrevista Coordenador A - UFMG.

${ }^{6}$ Não haveria tempo hábil para uma análise dos dados desse período, já que os mesmos foram divulgados a poucos meses da finalização da tese, em dezembro de 2013.
} 
A Avaliação da Capes é realizada a partir de informação fornecida pelos programas de pós-graduação, em sistema específico informatizado (Coleta Capes). Essas informações são analisadas por comissões específicas de especialistas, em cada área, que elaboram um relatório de avaliação e atribuem conceitos aos programas com base em pesos e valores definidos pela Capes para cinco quesitos, a saber: proposta do programa, corpo docente, corpo discente, produção intelectual e inserção social.

De acordo com a Avaliação da Capes, os programas são divididos em três tipos, que correspondem a três notas: 3 (regular), 4 (bom) e 5 (muito bom). Os programas com conceito 5 são submetidos a uma nova rodada de avaliação ${ }^{7}$ para serem classificado como 6 ou 7 (Programas de Excelência). Estas últimas são as notas concedidas, especialmente no caso da nota 7, a programas que, além de forte liderança nacional, apresentam um diferencial no seu desempenho, especialmente em termos de produção intelectual e de formação de recursos humanos comparáveis as de centros internacionais de excelência.

Para investigar o que é possível aprender com estes programas sobre a relação entre a sua posição de excelência e suas estratégias de gestão, adotamos uma abordagem qualitativa e realizamos estudos de caso desses quatro Programas de Pós-Graduação em Educação à luz, principalmente, das contribuições de Pierre Bourdieu e de Stephen Ball.

A abordagem do ciclo de políticas de Ball permite, junto com o conceito de performatividade, fazer a ponte entre o nível macro de definição das políticas para a área da pós-graduação e o nível micro da aplicação local, por meio da análise de documentos e da comparação do material coletado nos estudos de caso, notadamente os discursos e as práticas dos atores e os resultados obtidos pelos programas pesquisados.

Mais especificamente, acompanhando a análise do ciclo da política proposto por Ball, descrevemos, analisamos e comparamos as iniciativas de gestão dos programas selecionados em quatro contextos, a saber: de influência, de produção de texto, da prática e dos resultados.

O quadro teórico e conceitual para o estudo e interpretação das políticas e da gestão da pós-graduação em Educação foi construído, também e

\footnotetext{
${ }^{7}$ A partir da avaliação trienal 2013, os programas só concorrem à classificação de Programa de Excelência após permanecerem por duas avaliações com o conceito 5.
} 
principalmente, em diálogo com Bourdieu, notadamente com o conceito de “campo científico”, que permite entender a Área da Educação e os próprios programas de pós-graduação como um campo social, com formas específicas de relações de força e monopólio, lutas e estratégias, interesses e lucros.

Os principais achados da pesquisa mostraram que determinadas dimensões contextuais fazem diferença na atuação dos gestores, especialmente a forma de provimento do cargo, a preparação e a remuneração que os coordenadores recebem para exercê-lo, bem como o apoio técnico-administrativo disponível na instituição.

A análise comparativa das estratégias adotadas nos programas e as categorias surgidas da análise das entrevistas com os coordenadores revelaram algumas estratégias de gestão em comum, envolvendo: a gestão coletiva dos programas, a existência de uma política efetiva de credenciamento de docentes, um maior rigor com os prazos de titulação dos discentes e uma ênfase na vinculação do projeto do candidato ao mestrado ou doutorado com a pesquisa dos docentes do programa como crivo de seleção. Também permitiram observar a existência de uma diversidade de estratégias pedagógicas desenvolvidas pelos programas, muitas delas com ênfase na melhoria da produção discente. Em conjunto, estes achados da pesquisa revelam o papel dos coordenadores no alcance das notas que qualificam os programas estudados como Programas de Excelência.

Finalmente, a análise do contexto dos resultados nos permitiu observar como a posição de excelência trouxe aos programas lucros simbólicos e materiais, em termos do aumento da sua visibilidade e reconhecimento acadêmicos e de um maior acesso a recursos financeiros. Trata-se, no entanto, de ganhos conseguidos à custa da sobrecarga de trabalho dos coordenadores e do corpo docente dos programas estudados.

A tese está organizada em 8 capítulos, sendo o primeiro esta introdução. O capítulo 2 apresenta as referências teóricas e metodológicas do estudo, com ênfase no ciclo de políticas e no conceito de performatividade propostos por Stephen Ball e no conceito de campo científico de Pierre Bourdieu. No capítulo 3, é apresentado o desenvolvimento da pós-graduação no Brasil. O capítulo 4 é dedicado à explicitação das principais características da atual da Política de Pós- 
Graduação no Brasil, e suas injunções nos contextos de influência e de produção de texto que fazem parte do ciclo de políticas proposto por Ball. O capítulo 5 pode ser considerado o "coração” da pesquisa, na medida em que apresenta a relação dos coordenadores dos programas selecionados com a atual Política de PósGraduação, no contexto da prática, com destaque para as estratégias de “tradução” da política da Capes acionadas pelos coordenadores dos programas investigados. O capítulo 6, por sua vez, é dedicado à análise das questões que emergiram do contexto da prática, à luz das contribuições teóricas dos autores de referência, notadamente Stephen Ball e Pierre Bourdieu. No capítulo 7, abordamos o contexto de resultados, ou seja, os “efeitos” das estratégias adotadas pelos programas de pós-graduação para se relacionar com a atual Política de PósGraduação. No capítulo 8 apresentamos as conclusões, que retomam os principais contextos estudados, de modo a registrar, em uma nova síntese articulada, as estratégias de gestão adotadas pelos coordenadores dos programas pesquisados, destacando aquelas que contribuem para explicar a posição de excelência desses programas no campo educacional. 


\section{2.}

\section{Referências teóricas e metodológicas}

\section{1.}

\section{O escopo da pesquisa}

Para estudar a gestão de programas de pós-graduação, decidimos investigar, na Área da Educação, aqueles considerados “de excelência" pela Capes. Embora os critérios de Avaliação da Capes ainda sejam objeto de discussão entre a comunidade científica ${ }^{7}$, o resultado dessa avaliação é o balizador mais utilizado e aceito como referência da qualidade de um curso, razão pela qual resolvemos utilizá-lo como parâmetro de seleção em nossa pesquisa.

Assim, ao analisarmos os programas que conseguiram chegar ao restrito grupo dos Programas de Excelência, tendo avançado de nota duas vezes em três triênios, estamos supondo que os gestores e o corpo docente desses programas trabalharam intencionalmente (se planejaram, estabeleceram objetivos e metas a serem alcançadas, avaliaram desempenhos etc.) para conseguirem atingir os critérios de avaliação estabelecidos. Levamos em consideração, também, que o avanço de duas notas na escala de Avaliação da Capes e a entrada no grupo dos Programas de Excelência são dois feitos nada triviais.

Por recomendação da Capes, o grupo dos Programas de Excelência, que abarca os cursos de qualidade internacional (notas 6 e 7), deve representar não mais do que $10 \%$ do total dos programas existentes na Área (CAPES, 2013b). Nesse contexto, avançar duas notas nesse sistema, no espaço de três avaliações e ainda entrar no grupo dos Programas de Excelência é uma realização que certamente exigiu um grande esforço dos docentes e dos gestores.

No início dessa pesquisa, observamos os resultados obtidos desde a avaliação de 2001 pelos oito programas considerados de excelência pela Capes na avaliação 2010 (correspondente ao período 2007-2009), e constatamos que quatro desses programas tinham avançado de nota duas vezes nas Avaliações Trienais acontecidas entre 2001 e 2010: o Programa de Pós-Graduação em Educação da

\footnotetext{
${ }^{7}$ Ver capítulo 4 - Política de Pós-Graduação: influências internacionais e nacionais reveladas no contexto de produção de texto.
} 
Universidade Federal de Minas Gerais (UFMG), o Programa de Pós-Graduação em Educação da Universidade Estadual do Rio de Janeiro (Uerj), o Programa de Pós-Graduação em Educação da Pontifícia Universidade Católica do Rio Grande do Sul (PUCRS) e o Programa de Pós-Graduação da Universidade do Vale do Rio dos Sinos (Unisinos).

Os dois primeiros Programas mencionados eram considerados nota 5 (cinco) na avaliação trienal 2001 (correspondente ao período 1998-2000) e eram nota 7 (sete) na avaliação trienal 2010 (correspondente ao período 2007-2009). Enquanto que os dois últimos eram considerados nota 4 (quatro) na avaliação trienal 2001 e eram à nota 6 (seis) na avaliação trienal 2010. O quadro 2 permite observar os programas selecionados, as instituições às quais pertencem e a evolução das notas em cada um dos programas no período selecionado.

\section{Quadro 2: Notas dos Programas de Excelência na Área da Educação - avaliações trienais 2001-2010}

\begin{tabular}{|l|r|r|r|r|}
\hline Instituição & $\mathbf{2 0 0 1}$ & $\mathbf{2 0 0 4}$ & $\mathbf{2 0 0 7}$ & $\mathbf{2 0 1 0}$ \\
\hline PUC-Rio & 6 & 6 & 6 & 7 \\
\hline PUCRS & $\mathbf{4}$ & $\mathbf{5}$ & $\mathbf{5}$ & $\mathbf{6}$ \\
\hline Uerj & $\mathbf{5}$ & $\mathbf{6}$ & $\mathbf{6}$ & $\mathbf{7}$ \\
\hline UFF & 6 & 5 & 5 & 6 \\
\hline UFMG & $\mathbf{5}$ & $\mathbf{5}$ & $\mathbf{6}$ & $\mathbf{7}$ \\
\hline Ufscar & 5 & 5 & 5 & 6 \\
\hline Unisinos & $\mathbf{4}$ & $\mathbf{6}$ & $\mathbf{6}$ & $\mathbf{6}$ \\
\hline USP & 6 & 6 & 5 & 6 \\
\hline
\end{tabular}

Fonte: Capes, 2010.

O avanço na classificação obtida pelos quatro programas selecionados, e destacados no quadro em negrito, nos levou a supor que esses programas realizaram transformações internas significativas e positivas ao longo do período, que resultaram na melhora evidenciada em seus resultados. Esses programas não só tiveram o mérito de avançar duas notas, como também de chegar ao seleto 
grupo dos Programas de Excelência, o que faz com que se tornem referência para os demais programas da Área.

As quatro instituições escolhidas (PUCRS, Uerj, UFMG e Unisinos) são instituições tradicionais, que iniciaram seus Programas nas décadas de 1960/1970 e $1990^{8}$. Apesar desses aspectos em comum, as experiências apresentam singularidades relevantes. A primeira delas é que as instituições estão vinculadas a esferas administrativas diferentes. A Uerj e a UFMG são instituições públicas, sendo a primeira vinculada à esfera estadual (governo do estado do Rio de Janeiro) e a segunda à esfera federal. A PUCRS e a Unisinos são instituições particulares de ensino, de caráter confessional e filantrópico. Outra diferença é que as duas primeiras instituições iniciaram o período considerado com conceito muito bom (nota 5) e atingiram a nota 7 na avaliação de 2010, enquanto as últimas começaram com conceito bom (nota 4) e alcançaram a nota 6.

A pesquisa está relacionada à área de gestão em nível de pós-graduação stricto sensu (mestrado e doutorado). Com a escolha desse objeto de pesquisa, tivemos o intuito de colaborar com o aprimoramento e o desenvolvimento da produção acadêmica sobre o tema, uma vez que, apesar do forte crescimento experimentado pela pós-graduação nos últimos anos, são poucos os estudos sobre a gestão dos programas de pós-graduação nas diferentes áreas de conhecimento.

Ao realizar o estudo em tela, procuramos identificar e analisar os principais desafios enfrentados pelos gestores no atendimento às exigências da Capes e os caminhos trilhados em cada caso. O objetivo geral da pesquisa é compreender como se caracteriza a relação entre excelência e gestão em cada um desses quatro programas, com ênfase nas estratégias acionadas pelos seus coordenadores visando ao alcance dessa condição, ao longo das avaliações trienais 2001-2010. Em razão das limitações de tempo, essa pesquisa vai discutir a gestão dos programas do ponto de vista dos coordenadores. Com este estudo também pretendemos verificar a aplicação do modelo teórico e metodológico do ciclo de políticas de Stephan Ball e a categoria campo científico de Pierre Bourdieu na análise da gestão desses programas.

Sabemos que os parâmetros de Avaliação da Capes condicionam, em grande medida, as ações dentro dos programas; em razão disso, nos interessa

\footnotetext{
${ }^{8}$ Os cursos de mestrado da UFMG, da Uerj, da PUCRS e da Unisinos foram iniciados, respectivamente, em: 1965, 1972, 1972 e 1994.
} 
investigar qual a margem de autonomia de coordenadores e docentes em relação a esses parâmetros. Como eles os percebem? Que estratégias utilizam para se relacionar com a política da Capes? Qual o diferencial de cada programa? O que as experiências têm em comum?

$\mathrm{Na}$ busca desse objetivo e de respostas a essas questões, a pesquisa adotou uma abordagem qualitativa ${ }^{9}$, que envolveu quatro estudos de caso das experiências de gestão dos programas selecionados. O estudo de caso é indicado quando a questão de pesquisa envolve o estudo profundo e exaustivo de um ou poucos objetos, de maneira a permitir um amplo e detalhado conhecimento (SILVA; MENEZES, 2001).

No caso desta pesquisa, trata-se de um estudo de caso múltiplo, pois quatro programas foram pesquisados simultaneamente. A pesquisa leva em conta as mudanças ocorridas nos programas ao longo de três avaliações trienais, e adota uma perspectiva sociológica, que analisa a gestão dos programas levando em conta seus contextos institucionais e subjetivos.

Os procedimentos metodológicos adotados na coleta de dados incluíram análise documental e entrevistas semiestruturadas. A análise documental envolveu a consulta a documentos da Capes, relativos ao período de 1998 até 2014 (último ano da pesquisa), a saber: as Fichas de Avaliação dos Programas, os Documentos de Área, os Relatórios Síntese de Área, os Cadernos de Indicadores e dados de acesso livre de cada avaliação trienal. Também foi feito um levantamento de material bibliográfico sobre a pós-graduação e sobre o Sistema Nacional de Pósgraduação, e de documentos oficiais relativos à Política de Pós-Graduação, o que inclui, entre outros, os Planos Nacionais de Pós-Graduação (PNPG).

Visando compreender como é percebido o processo de gestão e investigar as estratégias de gestão adotadas pelos coordenadores, entrevistamos aqueles que ocuparam este cargo nos programas a partir de 2001 (ano de início do triênio 2004) até o ano de 2013 (momento da realização da pesquisa). Aqueles cuja gestão ocorreu entre 2010 e 2012 puderam contribuir com a pesquisa na medida em que já faziam parte do quadro de docentes no período entre 2001 e 2010 e atuavam em outras instancias coletivas de gestão, como colegiados ou comissões

\footnotetext{
${ }^{9}$ A abordagem qualitativa, segundo Minayo e Sanches (1993), é aquela que procura se aprofundar na complexidade dos fenômenos trabalhando com valores, crenças, representações, hábitos, atitudes e opiniões.
} 
dos programas. Também foram entrevistados membros da diretoria da Associação Nacional de Pós-Graduação e Pesquisa em Educação (Anped) e da coordenação do Fórum Nacional de Coordenadores de Programas de Pós-Graduação em Educação (Forpred), em atuação no ano de 2013 e, ainda, os dois últimos representantes da Área de Educação na Capes. Na definição desses sujeitos, levamos em conta que, em razão do seu posicionamento específico no campo da pós-graduação, poderiam ter pontos de vista diferentes em relação tanto às políticas da Capes como à gestão dos programas de pós-graduação stricto sensu da Área de Educação, que poderiam contribuir para enriquecer e para complexificar o material em análise.

As entrevistas foram realizadas ao longo do ano de 2013. Apenas uma delas só pôde ser realizada em janeiro de 2014, como é possível observar no quadro 3.

\section{Quadro 3: Entrevistas realizadas na pesquisa}

\begin{tabular}{|c|c|c|c|c|c|}
\hline Instituição & Cargo & $\begin{array}{r}\text { Triêni } \\
\text { relativo } \\
\text { gestã }\end{array}$ & $\begin{array}{l}\text { io } \\
\text { da }\end{array}$ & $\begin{array}{l}\text { Data da } \\
\text { entrevista }\end{array}$ & $\begin{array}{c}\text { Situação da } \\
\text { entrevista }\end{array}$ \\
\hline \multirow{4}{*}{ PUCRS } & Coordenador A & Triênios & $\begin{array}{l}2013 \\
2010\end{array}$ & $21 / 03 / 2013$ & Realizada \\
\hline & Coordenador B & Triênio & 2010 & $21 / 03 / 2013$ & Realizada \\
\hline & Coordenador $\mathrm{C}$ & Triênios & 2010 & 08/01/2014 & Realizada \\
\hline & Coordenador & Triênios & $\begin{array}{l}2007 \\
2004 \\
2001\end{array}$ & - & Recusou-se \\
\hline \multirow{5}{*}{ Uerj } & Coordenador A & Triênios & 2013 & $14 / 05 / 2013$ & Realizada \\
\hline & Coordenador B & Triênios & $\begin{array}{l}2013 \\
2010\end{array}$ & 09/05/2013 & Realizada \\
\hline & Coordenador $\mathrm{C}$ & Triênios & $\begin{array}{l}2010 \\
2007\end{array}$ & $08 / 05 / 2013$ & Realizada \\
\hline & Coordenador D & Triênio & 2007 & $03 / 07 / 2013$ & Realizada \\
\hline & Coordenador E & Triênios & $\begin{array}{l}2007 \\
2004\end{array}$ & $23 / 05 / 2013$ & Realizada \\
\hline \multirow{5}{*}{ UFMG } & Coordenador A & Triênios & 2013 & $04 / 04 / 2013$ & Realizada \\
\hline & Coordenador B & Triênio & 2013 & $04 / 04 / 2013$ & Realizada \\
\hline & Coordenador $\mathrm{C}$ & Triênios & $\begin{array}{l}2013 \\
2010\end{array}$ & 04/04/2013 & Realizada \\
\hline & Coordenador & Triênios & $\begin{array}{l}2010 \\
2007\end{array}$ & - & Recusou-se \\
\hline & Coordenador D & Triênio & 2007 & 04/04/2013* & Realizada \\
\hline
\end{tabular}




\begin{tabular}{|c|c|c|c|c|}
\hline & & & $05 / 04 / 2013$ & \\
\hline & Coordenador $\mathrm{E}$ & $\begin{array}{ll}\text { Triênios } & 2007 \\
& 2004\end{array}$ & $20 / 05 / 2013$ & Realizada \\
\hline \multirow{3}{*}{ Unisinos } & Coordenador A & Triênio 2013 & $22 / 03 / 2013$ & Realizada \\
\hline & Coordenador B & $\begin{array}{ll}\text { Triênios } & 2013 \\
& 2010 \\
\end{array}$ & $22 / 03 / 2013$ & Realizada \\
\hline & Coordenador $\mathrm{C}$ & $\begin{array}{ll}\text { Triênios } & 2007 \\
& 2004 \\
\end{array}$ & $21 / 03 / 2013$ & Realizada \\
\hline Anped & $\begin{array}{l}\text { Dirigente } \\
\text { Anped }\end{array}$ & $\begin{array}{ll}\text { Triênios } & 2013 \\
& 2010 \\
& 2007 \\
\end{array}$ & $16 / 05 / 2013$ & Realizada \\
\hline \multirow{3}{*}{ Capes } & CA-Edu A & 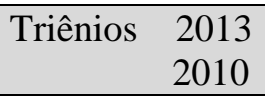 & $13 / 03 / 2013$ & Realizada \\
\hline & CA-Edu B & Triênio & $23 / 04 / 2013$ & Realizada \\
\hline & CA-Edu & Triênio $\quad \mathbf{2 0 0 4}$ & - & Faleceu \\
\hline Forpred & $\begin{array}{l}\text { Dirigente } \\
\text { Forpred }\end{array}$ & Triênios 2013 & $\begin{array}{l}\text { via e-mail } \\
11 / 07 / 2013\end{array}$ & Realizada \\
\hline
\end{tabular}

* Entrevista realizada em dois dias.

O quadro 3 permite observar que, das vinte e três entrevistas inicialmente planejadas, vinte foram realizadas. Três entrevistas não puderam ser realizadas, duas delas em razão dos ex-coordenadores terem se recusado a concedê-las. No caso da PUCRS, a recusa do coordenador que atuou em três triênios fez com que sua perspectiva em relação a esse período não fosse conhecida. Entretanto, os demais coordenadores deram depoimentos que permitiram identificar as estratégias de gestão e sua influência na trajetória ascendente dos programas nos últimos triênios. As entrevistas foram gravadas com prévia autorização dos entrevistados e transcritas posteriormente ${ }^{10}$.

Uma vez finalizado o trabalho de campo, as transcrições foram arquivadas no Programa QSR N-VIVO 10, um programa de análise de dados de pesquisa qualitativa e mapeadas por palavras-chave, que sustentaram a análise das experiências.

Especialmente útil foi o estudo de autores que abordam as temáticas relativas às experiências na área de gestão no ensino superior, à Avaliação da Capes e às Políticas de Pós-Graduação. Durante a análise, procuramos realizar uma contextualização dos dados levantados, relacionando-os aos demais materiais colhidos, como os Relatórios de Avaliações da Capes, a produção científica vinculada à área de gestão da pós-graduação e os autores escolhidos para

\footnotetext{
${ }^{10}$ Para que o leitor possa acessar ao roteiro e à condução da entrevista, conforme recomenda Brandão (2002), uma delas está disponível, na íntegra, no Anexo 2 desta tese.
} 
referenciar esta pesquisa do ponto de vista metodológico e teórico, notadamente Stephen Ball e Pierre Bourdieu.

Os estudos de Stephen Ball apresentam a "abordagem do ciclo de políticas", um modelo de leitura das políticas como um ciclo contínuo, constituído pelos contextos de influência, de produção de texto e da prática. Embora aborde cada um dos contextos indicados por Ball, nossa pesquisa enfatiza especialmente o estudo "contexto da prática", uma vez que nos interessa especialmente perceber como as diretrizes propostas no nível macro (Estado) foram reinterpretadas no nível micro (programas de mestrado e doutorado).

Complementarmente, levamos em conta o conceito de Stephen Ball de performatividade. Por meio da discussão da cultura da performatividade nos atuais sistemas de ensino, Ball aponta elementos presentes no contexto brasileiro da pós-graduação, relacionados seja com mudanças no papel do Estado, seja com a valorização de resultados quantitativos, seja com a busca de prestígio e reconhecimento pela comunidade acadêmica, bem como com seus impactos no campo da ética e do profissionalismo.

Outro autor que se constituiu em referência teórica fundamental desta tese é Pierre Bourdieu. Em especial, adotamos o conceito de "campo científico", definido por Bourdieu como aquele em que a distribuição e a acumulação de capital ocorrem através de uma luta entre os agentes acadêmicos em busca de legitimidade científica.

Neste capítulo, apresentaremos uma sistematização das contribuições específicas de Ball e de Bourdieu para o desenvolvimento desta tese, começando pela teoria elaborada por Stephen Ball para a análise da produção de políticas educacionais e pela categoria performatividade, para, logo a seguir, apresentar a nossa leitura sobre o conceito de campo científico em Bourdieu.

\section{2.}

\section{Contribuições de Stephen Ball ao estudo}

Não deixa de ser recorrente a visão de que as políticas educacionais são formuladas e impostas de cima para baixo, o que obrigaria os gestores educacionais a assumir ações que operariam mais de acordo com os interesses dos órgãos centrais do que com os interesses dos responsáveis pelas instituições. 
Nessa visão, a origem do distanciamento entre os objetivos das políticas e aquilo que, de fato, é realizado nas instituições educacionais estaria na falta de colaboração e na resistência dos professores.

O referencial analítico do ciclo de políticas de Ball e colaboradores (BOWE; BALL; GOLD, 1992; BALL, 1994) mostra-se fértil porque permite, ao mesmo tempo, superar essa visão reducionista da política educacional e reinscrevê-la na análise das influências mútuas entre os contextos macro e micro. Além disso, permite enfatizar os processos micropolíticos e a ação dos profissionais que lidam com as políticas no nível local, lançando luz sobre as possibilidades de intervenção e mudança postas pelas interações entre o contexto global e o contexto local.

Segundo Mainardes e Marcondes (2009), as pesquisas de Stephen Ball oferecem recursos intelectuais interessantes, uma vez que permitem perceber como as políticas são produzidas, o que elas pretendem e quais os seus efeitos. Em seus estudos, Ball aborda temas variados, procurando articulá-los a temáticas como justiça social, poder, desigualdades sociais, classes sociais e discurso. Por meio de uma perspectiva pluralista, Ball utiliza contribuições de Bourdieu, Foucault, Bernstein e Weber, colocando no centro do debate os processos micropolíticos e a necessidade da pesquisa articular as instâncias macro e micro.

Além dessa contribuição metodológica, Ball desenvolve o tema da performatividade, uma forma de regulamentação que atua por meio de julgamentos, indicadores e comparações. Para Ball (2004), a cultura da performatividade está inserida no contexto mais geral de transformações que geram mudanças no papel do Estado, nos serviços sociais, nas instituições, nas relações de trabalho e na subjetividade dos profissionais.

\subsection{1.}

\section{A abordagem do ciclo de políticas}

A "abordagem do ciclo de políticas" foi formulada por Stephen Ball e colaboradores (especialmente Richard Bowe) como um referencial de análise da trajetória de políticas sociais e educacionais. Segundo MAINARDES (2006), a: 
[...] reflexão sobre tal abordagem é bastante útil no contexto brasileiro uma vez que o campo de pesquisa em políticas educacionais no Brasil é relativamente novo e ainda não consolidado em termos de referenciais analíticos consistentes [...]. (p.48).

Ball propõe a leitura das políticas como um ciclo contínuo, formado, inicialmente, por três contextos: o "contexto de influência", o "contexto de produção de texto" e o "contexto da prática", que estão inter-relacionados, não constituindo etapas lineares com dimensão temporal ou sequencial (MAINARDES, ibid.).

O Contexto de Influência é aquele no qual as políticas são iniciadas e os discursos políticos são construídos, adquirem legitimidade e formam um discurso de base para a política. Nele atuam, especialmente, redes sociais relacionadas a partidos políticos, governos, comissões e grupos representativos que disputam a influência sobre a definição das finalidades da educação.

No contexto de influência da Política Brasileira de Pós-Graduação se encontram agentes e agências como o governo federal, a Capes e órgãos de fomento à pesquisa, como o CNPq, as comissões responsáveis pela elaboração das avaliações e dos PNPG, os representantes de programas e as associações nacionais representantes da pesquisa e dos programas em diferentes áreas. No caso da Área da Educação, destacam-se a Associação Nacional de Pesquisa e Pós-Graduação em Educação (Anped) e o Fórum Nacional de Coordenadores de Programas de Pós-Graduação em Educação da Anped (Forpred).

Além disso, Ball indica a presença de influências globais e internacionais no processo de formulação de políticas nacionais. Estas podem ser entendidas a partir do fluxo que envolve: (a) a circulação internacional de ideias; (b) o processo de empréstimo de políticas; e (c) os grupos de indivíduos que vendem soluções no mercado político e acadêmico. Ball faz referência, ainda, a uma segunda forma de influência, mais indireta, relacionada ao patrocínio e às soluções oferecidas e recomendadas por agências multilaterais, como o Banco Mundial, a Organização para a Cooperação e Desenvolvimento Econômico (OCDE), o Fundo Monetário Internacional (FMI), a Organização das Nações Unidas para a Educação, a Ciência e a Cultura (Unesco), por exemplo. Veremos que, no caso da pósgraduação, as influências internacionais se fazem presentes, mais especificamente, através da circulação de ideias entre os acadêmicos (autores, professores, 
pesquisadores e estudantes) e também, de forma indireta, pela adoção de parâmetros científicos internacionais, como aqueles que definem e avaliam a qualidade das publicações científicas.

O segundo âmbito, o Contexto de Produção de Texto, está relacionado com os textos sobre as políticas articulados à linguagem de interesse público mais geral, tais como textos legais, textos políticos, comentários formais ou informais, pronunciamentos etc. Os textos políticos são fruto de disputas e acordos entre diferentes grupos de interesses e, em razão disso, nem sempre são coerentes e claros. Nessa perspectiva, ao analisarmos o processo de produção de texto de determinada política é importante questionarmos quais são os grupos de interesse representados/excluídos, as vozes presentes/ausentes, se houve busca de consensos na construção do texto, se existem interesses não explicitados, se há inconsistências e contradições, a quem se destina o(s) texto(s) etc.

No contexto de produção de texto da Política de Pós-graduação Brasileira, encontramos a legislação sobre pós-graduação em vigor no país, como a Lei de Diretrizes e Bases da Educação (LDB), decretos, portarias e pareceres do MEC e do Conselho Nacional de Educação (CNE). Também estão nesta pauta os documentos emitidos pela Capes, como os PNPG, os documentos das Áreas de avaliação dos programas, os Cadernos de Indicadores, os textos sobre programas de indução, além de portarias, pareceres, mensagens aos coordenadores etc., documentos elaborados pelas agências de fomento (editais, convocações, programas etc.), e, ainda, documentos elaborados pelas Universidades e pelos próprios programas relacionados com a regulamentação desse nível de ensino.

Os textos relativos à Política de Pós-Graduação são reinterpretados no nível micro pelos atores que executam essa política. Nessa perspectiva, Mainardes (2006) aponta que, na concepção de Ball e Bowe,

\footnotetext{
[...] o foco da análise de políticas deveria incidir sobre a formação do discurso da política e sobre a interpretação ativa que os profissionais que atuam no contexto da prática fazem para relacionar os textos da política à prática. Isso envolve identificar processos de resistência, acomodações, subterfúgios e conformismo dentro e entre as arenas da prática, e o delineamento de conflitos e disparidades entre os discursos nessas arenas. (p.50).
}

Em razão disso, na pesquisa em tela, levamos em conta os processos de recontextualização acontecidos nos programas analisados. 
Para isso, foi necessário dar atenção especial ao terceiro contexto do ciclo de políticas: o Contexto da Prática, aquele no qual a política produz efeitos e consequências, estando sujeita a interpretações e recriações. Com Ball, entendemos que interpretação é disputa e que os sujeitos atuantes no contexto da prática interpretam, a partir de suas próprias histórias e experiências, as políticas de pós-graduação de forma ativa e diferenciada.

Mais especificamente, no contexto da prática é possível observar como a política foi recebida, como está sendo "colocada em ação", como os atores envolvidos interpretam os textos, se fazem alterações e adaptações, se há resistências individuais ou coletivas, se há contradições/conflitos/tensões. Também é importante observar se os profissionais envolvidos têm oportunidade de discutir e expressar dificuldades/opiniões/insatisfações e se recebem algum tipo de pressão ou suporte das instâncias que propuseram a política.

Relacionando o contexto da prática à Política Nacional de Pós-Graduação Brasileira de modo geral, é possível reconhecer que esta vem sendo executada com sucesso, embora encontre resistências entre a comunidade acadêmica. Apesar de a comunidade acadêmica reconhecer que o Sistema Nacional de PósGraduação vem apresentando uma evolução positiva em termos de resultados e que a pesquisa no país está se consolidando, são muitas as críticas encetadas à política vigente, especialmente no que diz respeito ao processo de avaliação coordenado pela Capes (TREIN; RODRIGUES, 2011; HORTA, 2006). Por sua vez, a própria Capes também aponta distorções e a necessidade de introduzir ajustes no sistema de avaliação (BRASIL, 2010). Esse tipo de crítica nos leva a deduzir que, no âmbito dos programas, fervilham contradições, tensões, resistências e conflitos que constituem mediações da Política de Pós-Graduação.

$\mathrm{Na}$ perspectiva dada ao contexto da prática por Ball, se fez necessário averiguar como os coordenadores interpretaram os textos da política, quais seus pontos de vista, como trabalharam para atingir os parâmetros estabelecidos pela Capes, quais os focos de resistências e de conflitos.

Esses três contextos (contexto de influência, contexto de produção de texto e contexto da prática) foram apresentados inicialmente por Ball na abordagem do ciclo de políticas, em $1992^{11}$. Dois anos depois, ${ }^{12}$ Ball acrescentou dois outros

\footnotetext{
${ }^{11}$ Ver: BOWE, R.; BALL, S.; GOLD, A. Reforming education \& changing schools: case studies in policy sociology. London: Routledge, 1992.
} 
contextos ao referencial inicial: o contexto de resultados ou efeitos e o contexto da estratégia política.

O Contexto dos resultados ou efeitos preocupa-se com questões de justiça, igualdade e liberdade. Nesse contexto, as políticas devem ser analisadas em termos de seu impacto, dos seus efeitos gerais ou específicos. De acordo com Ball, a análise de uma política deve envolver o exame (a) das várias facetas de uma política e suas implicações e (b) das interfaces da política com outras políticas setoriais e com o conjunto das políticas. Neste caso, Ball apresenta uma distinção entre efeitos de primeira ordem, relacionados a mudanças na prática ou na estrutura e, efeitos de segunda ordem, relacionados ao impacto dessas mudanças nos padrões de acesso social, oportunidade e justiça social.

O Contexto da estratégia política, por sua vez, refere-se à identificação de um conjunto de atividades sociais e políticas que seriam necessárias para lidar com as desigualdades criadas ou reproduzidas pela política investigada. É um componente essencial da pesquisa social crítica, produzido pelos intelectuais para uso estratégico nos embates no campo educacional.

Estes dois últimos contextos, no entanto, são pouco utilizados pelas pesquisas que adotam o referencial do ciclo da política de Ball (OLIVEIRA; LOPES, 2011). Em entrevista mais recente a Mainardes e Marcondes (2009), Ball considerou que a separação destes dois novos contextos em relação aos três contextos originais não é útil. Para ele, tanto o contexto de resultados e efeitos deveria ser incluído no contexto da prática, como o contexto da estratégia política deveria fazer parte do contexto de influência.

Diante disso, optamos por seguir a orientação mais recente do autor, focando nossa análise nos primeiros três contextos, sem deixar de abordar, no entanto, o contexto de resultados. Nesse caso, trataremos apenas dos "efeitos de primeira ordem", relacionados às mudanças ocorridas nos programas, face às injunções da Política de Avaliação da Capes.

\footnotetext{
${ }^{12}$ BALL, S. J. Educational reform: a critical and post-structural approach. Buckingham: Open University Press, 1994.
} 


\subsection{2.}

\section{O conceito de performatividade}

Além da abordagem do ciclo de políticas, Stephen Ball desenvolve outro conceito relacionado com a presente pesquisa: o de performatividade. Para o autor, a performatividade é:

\footnotetext{
Um mecanismo de controle, uma forma de controle indireto ou de controle à distância que substitui a intervenção e a prescrição pelo estabelecimento de objetivos, pela prestação de contas e pela comparação. [...] a performatividade fornece sistemas de signos que "representam" a educação de uma forma auto-referencial e reificada para o consumo. (BALL, 1998, p.127)
}

Ball (2004) argumenta que a cultura da performatividade está incluída no contexto de transformações provocadas pelo que chama de "acordo político do Pós-Estado de Bem-Estar", que gera mudanças no papel do Estado, nos serviços sociais, nas instituições do setor público e dos cidadãos. Essas mudanças, introduzidas pelo gerencialismo no setor público, afetam o modo como entendemos o profissionalismo, as relações de trabalho e as subjetividades. Essas mudanças não ocorrem de forma abrupta, são antes um processo de "contínua fricção", de introdução e consolidação de grandes e pequenas alterações, com diferentes "palcos da mudança".

O primeiro deles refere-se às "mudanças em relação ao papel do Estado", que diminui sua intervenção como provedor e assume papéis de regulador, auditor e avalista, o que lhe permite dirigir as atividades do setor público "a distância". De acordo com Ball, cada vez mais, as políticas sociais são pensadas em função do aumento da competitividade econômica da nação. Nessa perspectiva, a política social passa a ser vista em sua dimensão econômica e a educação (ensino básico, profissional e superior) como uma forma de desenvolver o capital humano, o que leva a um aumento das intervenções do Estado em atividades sociais e econômicas, tendo na avaliação o elemento fundamental da mudança.

O segundo palco de mudança é o que Ball nomeou de "interesses do capital”. Segundo o autor, o mundo dos negócios está cada vez mais focado nos serviços educacionais como uma área lucrativa em expansão. A educação passa a ser uma (boa) oportunidade de negócio. Há evidências de uma participação cada 
vez maior do setor privado na gestão, na prestação e no financiamento de serviços do setor público, especialmente na Comunidade Europeia e nos Estados Unidos. O que tem ocorrido, para o autor, é uma americanização da economia mundial e um processo de "alinhamento" entre países desenvolvidos e em desenvolvimento.

Entretanto, Ball (2004, p. 114) alerta que “[...] as coisas não são tão simples e nítidas assim. As tendências têm ritmos diferentes em lugares diferentes." Para o autor, no processo de recontextualização, as tendências globais sofrem acomodações através de resistências, variações e especificidades locais e as mudanças na educação decorrentes desse cenário são multifacetadas e complexas.

"Instituições do setor público, performatividade, ética e danos colaterais" compõem o terceiro palco de mudança. A performatividade vem desempenhando um papel importante nesse conjunto de políticas, permitindo que o Estado se insira profundamente nas culturas, práticas e subjetividades das instituições do setor público e de seus trabalhadores, através do discurso da eficiência e da qualidade.

Em outro artigo sobre o tema, Ball (2005), descreve performatividade como:

\begin{abstract}
[...] uma tecnologia, uma cultura e um método de regulamentação que emprega julgamentos, comparações e demonstrações como meios de controle, atrito e mudança [...] alcançada mediante a construção e publicação de informações e de indicadores, além de outras realizações e materiais institucionais de caráter promocional, como mecanismos para estimular, julgar e comparar profissionais em termos de resultados: a tendência para nomear, diferenciar e classificar. (p. 543).
\end{abstract}

No âmbito educacional, a prática profissional passa a ser influenciada por regras e metas estabelecidas de modo exógeno. O ensino, ação que exige interação humana, sofre um processo de objetivação de forma a ser padronizado, qualificado e comparado. Os sistemas de gestão passam a visar, prioritariamente, o desempenho, a melhoria da qualidade e a eficácia. Ball acredita que, em consequência disso, a performatividade e a mudança no perfil da gestão acabam por focar no processo de cumprimento de metas e na maximização do orçamento, por vezes, em detrimento das questões éticas, como a justiça social, a equidade e a tolerância. As mudanças são incorporadas como caminho para a excelência e há pouco debate sobre as consequências éticas das novas práticas. Com isso, as 
relações setor público/ setor privado/ Estado/ cidadão são profundamente alteradas.

Num texto de 2005, Profissionalismo, Gerencialismo e Performatividade, Ball discute também o fato de o novo contexto educacional, que envolve a cultura da gestão e da performatividade, acabar provocando mudanças na formação da identidade profissional dos professores. O profissionalismo é uma relação específica entre o profissional e seu trabalho baseada na reflexão moral, que tenta organizar a prática através de tomadas de decisão "corretas". Entretanto, esse termo perde sentido dentro de uma estrutura dominada pela racionalidade técnica, já que os critérios de qualidade e boa prática são fechados e completos. Some-se a isso, a definição de metas ambiciosas de perfeição e desempenho, que acabam gerando novos papéis e subjetividades, pelos quais os professores, pesquisadores e acadêmicos passam a ser considerados produtores/fornecedores, sujeitos a julgamentos, mensurações, comparações e metas.

Um elemento importante para nossa pesquisa é o papel de destaque que o gestor ocupa nesse contexto. Segundo Ball (2002):

\begin{abstract}
A figura central, o herói, no meio disto tudo, e o principal beneficiário da reforma, é um actor relativamente novo no palco das organizações do sector público - o gestor. O propósito da devolução, como refere a OCDE, é "encorajar os gestores a centrarem a sua acção nos resultados, dando-lhes flexibilidade e autonomia no uso de recursos humanos e financeiros". (p. 6).
\end{abstract}

Não é difícil estabelecer relações entre as temáticas abordadas por Ball em torno da performatividade e aspectos do sistema educacional brasileiro, especificamente o ensino de pós-graduação. A política atual, que conta com a Avaliação da Capes como carro-chefe do sistema, permite observar a presença de vários pontos em comum com esse conceito. É o Estado, através da Capes, que reconhece os programas de pós-graduação e os avalia periodicamente, determinando sua "posição" no sistema. Embora ocorra um trabalho de acompanhamento e de orientação dirigido aos programas, há uma ênfase na função auditora da Capes, expressa no estabelecimento de parâmetros e metas e, principalmente, na avaliação dos seus resultados. O conceito de performatividade também pode ser aplicado à realidade atual da produção acadêmica da pósgraduação. É cada vez maior a preocupação com os resultados da produção qualificada na avaliação dos programas (artigos em periódicos), parâmetro 
fundamental para se atingirem as melhores notas no sistema e, assim, ter acesso a mais recursos e reconhecimento.

Moreira (2009), no artigo A cultura da performatividade e a avaliação da pós-graduação no Brasil, aborda esse tema ao associar os princípios, procedimentos e efeitos da avaliação, nos moldes da cultura da performatividade descrita por Ball, com os recentes rumos da pós-graduação brasileira. O autor aponta que as mudanças na avaliação da pós-graduação no Brasil, introduzidas a partir de 1998 e consolidadas nos triênios seguintes, privilegiam os resultados quantitativos de produção científica e têm levado docentes e pós-graduandos a publicarem com mais intensidade e regularidade.

Se, por um lado, o aumento da produtividade é positivo, por outro, gera consequências negativas nessa forma de fazer ciência. A principal delas é a mudança provocada na subjetividade dos professores. A competição gravita em torno do prestígio acadêmico, do território e dos recursos e faz com que as relações se pautem menos na solidariedade do que na concorrência. $O$ desempenho expressa o valor do indivíduo e da organização, e o compromisso docente é avaliado pela capacidade de alcançar os resultados esperados. Moreira (2009) aponta, como efeito perverso da cultura da performatividade, o aumento das pressões e do estresse emocional, do ritmo e da intensificação dos esforços para alcançar metas e, ainda, das atividades burocráticas, que crescem em função do número cada vez maior de registros e relatórios. Soma-se a isso a divulgação de uma produção realizada de forma rápida e apressada, sem o necessário tempo de maturação, reflexão e discussão das ideias difundidas.

Para o autor, a acentuada valorização, seja das publicações em veículos qualificados, seja da categorização de editoras/periódicos/eventos, seja da participação em congressos/eventos, bem como a redução do tempo de titulação terminam por "conformar e reformar a pós-graduação". Essas mudanças caminham, para ele, no sentido contrário aos ideais e valores éticos humanistas que deveriam pautar o ensino e que implicam em uma "práxis utilizável" por pessoas que desejam saber o que estão fazendo, quais seus compromissos como estudiosos e como conectar esses princípios com o mundo em que vivem como cidadãos.

No modelo vigente, a avaliação reserva pouco espaço para a consideração das circunstâncias em que os objetivos são perseguidos e os resultados são 
produzidos. Para Moreira, a qualidade docente não pode ser expressa apenas na forma de publicação, devendo implicar também em ser um bom docente, demonstrar competência em cargos administrativos, beneficiar o coletivo da instituição e contribuir para a construção de uma Universidade de qualidade. O autor contribui, assim, com referências para o aprofundamento do debate sobre o tema, pela via da investigação das vozes dissonantes porventura existentes entre os sujeitos investigados.

\section{3.}

\section{Contribuições de Bourdieu ao estudo}

Segundo Thiry-Cherques (2006), Pierre Bourdieu construiu uma teoria da prática que marca o "retorno ao sujeito" e constitui uma referencia obrigatória no pensamento social desse início de século. Bourdieu nega, a um só tempo, tanto o determinismo e a estabilidade das estruturas como o individualismo metodológico, segundo o qual o fenômeno social é unicamente produto de ações de sujeitos individuais. Para Bourdieu, o indivíduo está inserido em uma estrutura dinâmica e é, ao mesmo tempo, uma força estruturante de um campo. Seus conceitos primários são o de habitus, um sistema de disposições que leva o sujeito a agir de forma determinada; e o de campo, microcosmos sociais caracterizados por agentes dotados do mesmo habitus.

O conceito de habitus é a mais popular das ideias de Bourdieu (BRANDÃO, 2010) e refere-se aos modos de perceber, de sentir, de agir, de pensar dos agentes em uma circunstancia dada. O habitus está na mediação entre estrutura e ação. Para Caria (2002) o habitus é definido como:

\footnotetext{
[...] um conjunto de esquemas pré-reflexivos (disposições) de percepção, apreciação e antecipação que foram produzidos no agente social. Estes esquemas são o resultado de um trabalho de inculcação pela prática (ver fazer e fazer acompanhando os que sabem fazer) em que o agente social interioriza, de modo sistemático e coerente, as estruturas de relações de poder, a partir do lugar e da posição que nelas ocupa, e exterioriza em práticas as disposições (os esquemas pré-reflexivos estruturados) que antes interiorizou. (p.04)
}

Habitus são disposições interiorizadas duráveis (estruturas) geradoras de práticas e representações (estruturantes). Funciona como um esquema de ação, percepção, reflexão e é relativamente autônomo, pois, "não é destino" e preserva 
uma margem de liberdade com relação ao agente. O habitus é tanto individual quanto coletivo e se situa em um determinado universo social, isto é, num campo que o circunscreve. É um saber agir aprendido pelo agente na sua inserção em um determinado campo. As "estruturas" do campo são importantes na formação do habitus, mas a ação dos agentes não é completamente determinada por elas (THIRY-CHERQUES, 2006; BRANDÃO, 2010).

O campo é tanto um "campo de forças" quanto um "campo de lutas", em que os agentes atuam conforme suas posições, conservando ou transformando as estruturas. Os campos são microcosmos sociais, com valores, objetos e interesses específicos e se caracterizam por agentes dotados do mesmo habitus. O campo estrutura o habitus, que, por sua vez, constitui o campo. Este é um espaço de relações objetivas entre os indivíduos, coletividades ou instituições, que competem pela dominação e por posições dentro dele.

Bourdieu denomina como capitais os interesses postos em jogo, referindose tanto a bens econômicos, como também culturais, sociais, simbólicos etc. Segundo Thiry-Cherques (2006):

[...] os agentes necessitam de um montante de capital para ingressarem no campo e, inconscientemente, fazem uso de estratégias que lhes permitem conservar ou conquistar posições, em uma luta que é tanto explícita, material e política, como travada no plano simbólico e que coloca em jogo os interesses de conservação (a reprodução) contra os interesses de subversão da ordem dominante no campo. (p. 37).

Para Bourdieu, todo campo é uma arena de conflito entre os agentes que monopolizam o capital específico do campo e os agentes com pretensão de dominá-lo. Dominação esta, em geral, não evidente, exercida por meio de uma violência simbólica e com a cumplicidade daquele que a sofre. A dominação não é efeito de uma luta aberta, mas de um conjunto de ações infraconscientes. Em todo campo, a distribuição de capitais é desigual, o que implica em conflitos e estratégias para defender diferentes interesses. As estratégias mais comuns estão relacionadas à conservação, investimento, sucessão e acumulação do capital específico. Em geral, as estratégias não são calculadas nem intencionais. Trata-se de uma luta, na maioria das vezes, não consciente pelo poder.

Além destas propriedades gerais, comuns a todos os campos, existem características específicas, como acontece com o campo científico, que está submetido à lógica da ciência. 


\subsection{1.}

\section{O campo científico}

Para Bourdieu (1983a), o campo científico é o lugar de uma luta concorrencial, na qual está em jogo o monopólio da competência científica (capacidade de falar e agir de maneira autorizada e com autoridade). Esta abordagem revela que as práticas desse campo não são "desinteressadas", mas produzem e supõem uma forma especifica de interesse. Segundo ele "[...] os eruditos são interessados, têm vontade de chegar primeiro, de brilhar." (BOURDIEU, 2004, p. 31).

No campo científico, as convenções e aparatos modificam a percepção social da capacidade propriamente técnica. Assim, os julgamentos sobre a capacidade técnica de alguém estão sempre contaminados pelo conhecimento da posição que essa pessoa ocupa nas hierarquias instituídas no campo. Isto resulta no fato de que o interesse por uma atividade científica tem sempre uma dupla face, já que as práticas são orientadas para a aquisição de autoridade. "O que é percebido como importante e interessante é o que tem chances de ser reconhecido como importante e interessante pelos outros.” (BOURDIEU, 1983a, p. 127). Nesse sentido, não há escolha científica que não seja uma estratégia política de investimento objetivamente orientada para a maximização do lucro científico, no sentido do reconhecimento dos pares.

As transformações do campo científico baseiam-se na estrutura de distribuição do capital científico e se manifestam nas estratégias de conservação e subversão da estrutura que ele mesmo produz. Os investimentos dos pesquisadores dependem, tanto na sua importância quanto na sua natureza, da importância de seu capital atual e potencial de reconhecimento e de sua posição atual e potencial no campo. As ambições científicas são tanto mais altas quanto mais elevado é o capital em termos de reconhecimento.

No campo científico, a distribuição do capital ocorre através de uma luta científica e política pela legitimidade, entre agentes desigualmente dotados de capital específico. Em todo o campo se opõem os dominantes e os dominados (novatos). À medida que crescem os recursos científicos acumulados, eleva-se o grau de homogeneidade entre os concorrentes e as estratégias de manutenção e 
subversão tendem a se enfraquecer na medida em que cresce a homogeneidade do campo.

Segundo Bourdieu, aos dominantes consagram-se, assim, às estratégias de conservação, visando à perpetuação da ordem científica. Essa ordem não se reduz à ciência oficial, ela engloba também o conjunto das instituições encarregadas de assegurar a produção e a circulação dos bens científicos e, ao mesmo tempo, a circulação e a reprodução dos produtores e consumidores desses bens, ou seja, o sistema de ensino como um todo. Os novatos, por sua vez, podem orientar-se por "estratégias de sucessão", mais seguras e previsíveis, dentro de limites autorizados. Podem orientar-se, ainda, por "estratégias de subversão", mais arriscadas porque só podem assegurar lucros se houverem mudanças que permitam uma redefinição completa dos princípios de legitimação da dominação.

Em sua obra Os usos sociais da ciência: por uma sociologia clínica do campo científico, Bourdieu (2004) classifica o capital científico em duas espécies: "capital científico puro", relativo a contribuições reconhecidas ao progresso da ciência (invenções, descobertas, publicações) e, "capital científico institucional", que se adquire por estratégias políticas que exigem tempo (participação em bancas, comissões, colóquios, reuniões, ocupação de cargos etc.). Esta classificação é particularmente interessante para essa pesquisa, já que o cargo de coordenador de programa de pós-graduação se enquadra nessa última forma de capital.

O autor indica que ao capital científico puro corresponde o poder específico do "prestígio" que repousa sobre o reconhecimento, pelo conjunto de pares, da produção científica do agente. Este capital tem algo de impreciso, indeterminado e carismático ligado aos dons pessoais e, portanto, de difícil transmissão na prática. No entanto, o pesquisador pode transmitir a parte mais formalizada de sua competência científica, por meio de um longo e lento trabalho de formação.

O capital científico institucionalizado, por sua vez, é relativo ao poder temporal ou político (institucional e institucionalizado) resultante da ocupação de posições importantes nas instituições científicas, direção de laboratórios ou departamentos, pertencimento a comissões, comitês de avaliação etc. e, ainda, do poder sobre os meios de produção (contratos, créditos, postos) e reprodução que ele assegura (poder de nomear e fazer carreira). Este tipo de capital possui as 
mesmas formas de transmissão que qualquer outro capital burocrático e pode ocorrer por meio de nomeações, concursos, eleições, entre outros.

Para Bourdieu, o acúmulo das duas espécies de capital é extremamente difícil, pois são necessários investimentos diferentes. O tempo consumido na ocupação de cargos de gestão, por exemplo, pode comprometer o tempo da produção científica do pesquisador. Portanto, pesquisadores podem estar em lados opostos: uns com muito capital científico puro e pouco capital científico institucionalizado; outros com grande capital institucionalizado e pouco capital científico puro.

Todavia, a acumulação de crédito científico junto aos pares pode provocar, ainda que tardiamente, a obtenção de poder político e econômico. A conversão de capital político em crédito científico, por sua vez, pode ser mais fácil, pois o poder que seus detentores estão aptos a exercer sobre a produção e a reprodução lhes dá condições de "[...] assegurar a perpetuação da ortodoxia contra a inovação [...]" (BOURDIEU, 2004, p. 39). Ou seja, Bourdieu acredita que a conversão de capital político em científico é mais fácil do que o contrário.

As considerações de Bourdieu sobre o campo científico e seus capitais (puro e institucional) serão de fundamental importância na análise das experiências pesquisadas. O meio acadêmico, no qual se inserem os programas de pós-graduação, está permeado pelas hierarquias institucionais, as lutas concorrenciais, a distribuição desigual de capital científico e de poder. Neste caso, Bourdieu dirige nosso olhar para a utilização de estratégias de conservação, investimento, sucessão e acumulação desses capitais, pelos agentes da pesquisa, mesmo que de forma não calculada ou intencional.

Nos próximos capítulos, procuramos relacionar os conceitos de Ball e Bourdieu aos elementos levantados no trabalho de campo da pesquisa, de forma a interpretá-los desvelando questões que se apresentam nas arenas de ação dos sujeitos pesquisados, ou seja, os coordenadores de programas. Levando em conta essas referências, procuramos responder à seguinte questão de pesquisa: Quais as estratégias adotadas pelos gestores dos programas de excelência investigados, entre 2001-2010, que podem ter contribuído para o alcance dessa condição?

As outras questões de pesquisa que também nortearam nosso trabalho de campo, tiveram, entre outras influências, o roteiro apresentado por Mainardes 
(2006) para estudos que utilizam o referencial teórico proposto por Stephen Ball, e foram agrupadas em quatro tópicos, a saber:

\section{Questões relativas ao contexto de influência}

Há influências internacionais na Política de Pós-Graduação Brasileira? De que forma elas se revelam? Quais as principais influências nacionais? Quais entidades/ atores sociais se revelam com mais poder de influenciar os rumos dessa política?

\section{Questões relativas ao contexto da produção de texto}

Quais os principais textos da atual Política de Pós-Graduação? Que atores participam de sua elaboração? Houve participação dos profissionais que operam com a política na elaboração dos textos? Houve grupos excluídos? Houve intenção de se buscar consensos na escrita dos textos? Quais deles mais pautam e influenciam o trabalho de gestão dos programas de pós-graduação pesquisados?

\section{Questões relativas ao contexto da prática}

Como os agentes entrevistados se relacionam com a Política de PósGraduação? Quais as instâncias de gestão dos programas (coordenação, vice, colegiado etc.)? Quais as dimensões contextuais da gestão nos programas pesquisados? Qual a visão dos mesmos em relação ao tema da excelência? E em relação ao processo de Avaliação da Capes? Há evidências de resistência docente individual ou coletiva? Os profissionais envolvidos nas experiências têm autonomia e oportunidades de discutir e expressar dificuldades, opiniões, insatisfações, dúvidas? Há contradições, conflitos e tensões entre as interpretações expressas pelos profissionais que atuam na prática e as formulações da política? Como os gestores "traduzem" os parâmetros de Avaliação da Capes para discentes e docentes? Que estratégias foram adotadas pelos programas para chegarem ao nível de excelência em que se encontram? Quais são as principais dificuldades identificadas? 
Questões relativas ao contexto dos resultados ou efeitos

Quais os resultados ou efeitos das mudanças realizadas? Quais as principais consequências para os programas de terem passado a fazer parte do grupo dos Programas de Excelência?

Os próximos capítulos apresentam nossa tentativa de encontrar respostas para essas questões. 


\section{3.}

\section{Histórico da Pós-Graduação no país}

O Brasil desenvolveu tardiamente seu ensino superior, quando comparado a outros países da América Latina que tiveram colonização espanhola. Enquanto nossos vizinhos possuíam Universidades desde o século XVI, aqui o primeiro curso superior surge apenas no século XIX.

Todavia, ao longo do século XX, o ensino superior foi crescendo no país e, em conjunto com a criação posterior da pós-graduação levou à multiplicação do número de cursos, que passaram a atender a uma parcela crescente de alunos, ao mesmo tempo em que a Universidade diversificava e especializava suas atividades de ensino e pesquisa em diferentes áreas de conhecimento.

Complementarmente, o desenvolvimento de uma política para a pósgraduação stricto sensu, com destaque para o Sistema de Avaliação da Capes, levaria ao reconhecimento da qualidade das atividades desenvolvidas no âmbito da pós-graduação pela comunidade científica internacional.

Segundo Balbachevsky (2005), esse reconhecimento não é tributário apenas do crescimento quantitativo do número de cursos e alunos ${ }^{14}$. Ele também é fruto de um conjunto consistente de políticas e da avaliação conduzidas pela Capes que garantiram o apoio material oficial ao desenvolvimento dos programas e forneceram a referência do que deveria ser o padrão de qualidade a ser atingido.

Para entender os caminhos que promoveram esse desenvolvimento quantitativo e qualitativo da pós-graduação brasileira é importante considerar sua trajetória histórica. Esse é o objetivo deste capítulo que aborda a criação e o desenvolvimento da pós-graduação no Brasil, sob a influência do nacional desenvolvimentismo, da Reforma do Ensino Superior e dos Planos Nacionais de Pós-Graduação.

\footnotetext{
${ }^{14}$ Segundo dados do GeoCapes, em 2012, o Brasil tinha 3.342 programas de pós-graduação, com 71.507 professores, 109.515 alunos de mestrado acadêmico matriculados, 79.478 de doutorado e 14.724 de mestrado profissional.
} 


\section{1.}

\section{Notas sobre a origem e o desenvolvimento da pós-graduação no Brasil}

O surgimento das atividades de pós-graduação no Brasil ocorreu em meados do século $\mathrm{XX}$, quando o país vivia o período do nacional desenvolvimentismo, que dava à educação um papel de destaque. Embora a defesa da educação como força propulsora do desenvolvimento da nação estivesse presente no discurso político da década de 1920, foi somente no governo de Getúlio Vargas (1930-1945) que o campo educacional efetivamente se tornou área da política setorial do Estado, dando origem às primeiras atividades de pósgraduação no país, cuja estruturação só viria a acontecer mais tarde, nas décadas de 1950 e 1960.

O projeto de Estado da Era Vargas (1930-1945/ 1951-1954) foi pautado pela racionalização administrativa e teve na centralização, na padronização e na burocratização da ação pública suas principais características. Embora o entendimento da educação como problema nacional justificasse a intervenção intensa do governo, nesse período, a União era responsável somente pelo ensino médio e superior e a educação básica recebia pouca atenção.

O ministro da Educação que atuou durante a maior parte do período Vargas, Gustavo Capanema (1934-1944), ao mesmo tempo em que apoiou o grupo dos intelectuais escolanovistas e cercou sua administração de uma imagem de modernização, se vinculou à Igreja Católica, realizando, em seu governo, o que os estudiosos chamam de uma "modernização conservadora" (XAVIER, 1999, p. 27). Nesse processo, foi enfatizado o ensino humanista nas escolas secundárias que formavam as elites para as Universidades, em detrimento da formação técnica e científica, restando às camadas populares a escola primária ou as escolas profissionais menos valorizadas.

A crença na educação como possibilidade de modernização e de difusão de um projeto de nação marca o momento da institucionalização da pós-graduação brasileira. As primeiras experiências de estudos de pós-graduação tinham surgido ainda nos anos 30 do século passado, nas Universidades federais. Essas Universidades atraíam professores estrangeiros que trabalhavam no modelo de 
cátedra, no qual um professor (catedrático) que possuía um grupo de discípulos era o único responsável pelas atividades de pesquisa e ensino da disciplina em que ele era especialista. O elemento central desse modelo era a relação tutorial que se estabelecia entre o professor e os discípulos que atuavam como auxiliares do professor nas atividades de ensino e pesquisa.

Naquele momento, os estudos de pós-graduação eram conduzidos de forma pulverizada e tinham pequenas dimensões. Isso acontecia, em parte, porque, fora do mundo acadêmico, os títulos oferecidos pela pós-graduação eram ainda pouco conhecidos. Saviani, explica o processo de formação de pesquisadores e professores nesse contexto:

\begin{abstract}
Os cursos oferecidos se situavam no nível de graduação e a formação de pesquisadores e dos professores da própria Universidade se dava por um processo espontâneo, geralmente através da agregação, pelo catedrático ou pelo responsável pelas diferentes cadeiras, de aluno recém-formado que havia se destacado nos estudos realizados e que era convidado a participar das atividades da disciplina como auxiliar de ensino ou assistente, preparando-se para reger a cadeira como livre docente com perspectiva de vir a se tornar catedrático. Era, assim, uma espécie de formação em serviço [...]. (SAVIANI, 2000, p. 4).
\end{abstract}

Os professores catedráticos eram autossuficientes e muitas vezes se posicionavam "acima das regras". O regime de cátedra, personalista e autocrático, marcou profundamente a Universidade brasileira e tem reflexos em sua cultura organizacional até os dias atuais. Essa cultura, muitas das vezes, se manifesta em relações hierárquicas que acabam sendo mais fortes que as relações de grupos (VERHINE, 2008; ALMEIDA, 2008).

O projeto nacional desenvolvimentista ganhou novo fôlego com a queda do Estado Novo e o início do processo de redemocratização do país, a partir de 1945. Em linhas gerais, o nacional desenvolvimentismo almejava ingressar o Brasil na modernidade através do desenvolvimento industrial, do planejamento, do recurso estrangeiro e da racionalidade administrativa. $\mathrm{O}$ pressuposto básico do bem estar social era o crescimento econômico. A educação destacava-se por suas dimensões política (função democratizadora) e econômica (produtividade e progresso material). A intenção na administração pública de sobrepor a competência técnica a critérios políticos resultou na ampliação da participação dos intelectuais no aparelho estatal. 
O governo mais representativo da ideologia nacional desenvolvimentista foi o do presidente Juscelino Kubitschek (1956-1961). A educação entrou em seu famoso Plano de Metas, que abrangia ainda outros quatro setores considerados "estranguladores" do desenvolvimento do país: energia, transportes, alimentação e indústria de base. A meta relacionada ao setor educacional, todavia, era circunscrita à questão técnica: "intensificar a formação de pessoal técnico e orientar a educação para o desenvolvimento" (XAVIER, 1999, p.33). Tais diretrizes educacionais voltadas ao desenvolvimento da técnica e da ciência aproximavam-se das recomendações de órgãos internacionais que, como a Unesco, apoiavam projetos contra o analfabetismo, visto como um grande obstáculo para o progresso da nação.

Foi em 1951, durante o segundo governo de Getúlio Vargas, e no contexto do conjunto de medidas voltadas para a promoção do desenvolvimento econômico e social que buscavam a superação da dependência cientifica e tecnológica do Brasil em relação aos países desenvolvidos, que foi criada a Campanha Nacional de Aperfeiçoamento de Pessoal de Nivel Superior (Capes) ${ }^{15}$, com a responsabilidade de elaborar e executar uma política para esse nível educacional no país. Com essa medida, o governo desejava assegurar a formação de recursos humanos especializados e qualificados para atender às necessidades do Estado e da iniciativa privada (SOUZA; PEREIRA, 2002).

Mendonça et al. (2001) destacam o protagonismo de Anísio Teixeira na criação e institucionalização da Capes, órgão do qual foi secretário-geral durante a vigência de diferentes governos, entre 1951 e 1964.

Em 1950, quando Anísio ainda era Secretário de Educação e Saúde do estado da Bahia, escreveu para o então Ministro da Educação, Clemente Mariani, o documento Sugestões para um plano de auxílio ao ensino superior do país, no qual abordava a situação do ensino superior e da pós-graduação no Brasil, criticando sua seletividade e apontando para a urgência de se proceder a levantamentos sobre as reais necessidades do país em relação à formação de quadros superiores, aventando a possibilidade de contratação de professores

\footnotetext{
${ }^{15}$ Decreto $\mathrm{n}^{\circ} 29.741$, de 11 de julho de 1951. Institui uma comissão para promover a Campanha Nacional de Aperfeiçoamento de Pessoal de nível Superior.
} 
estrangeiros e sugerindo critérios para seleção de bolsistas. Esses aspectos serviriam de base para o processo de construção da Capes.

Anísio Teixeira tinha uma preocupação muito grande com a descentralização e organização de um Sistema Nacional de Ensino e, para ele, a Capes seria o primeiro passo para o planejamento do desenvolvimento nacional. O intelectual foi o mediador das discussões entre dois grupos antagônicos que ocupavam o centro das decisões durante os primeiros anos da Capes: o grupo dos "pragmáticos", que almejava reformas mais imediatas e qualificação profissional; e o grupo dos "políticos", que postulava objetivos de médio e longo prazo e tinha sua preocupação voltada à produção científica nacional.

Nos primeiros anos de funcionamento da Capes, foram criados programas voltados especificamente para a pós-graduação, como os relacionados à concessão de bolsas de estudos e ao fomento para a criação e a manutenção dos programas, bem como para a promoção da avaliação da pós-graduação stricto sensu (GOUVÊA; MENDONÇA, 2006; SOUZA; PEREIRA, 2002). Esses primeiros anos de atuação da Capes estabeleceram as bases para a significativa expansão que o ensino de pós-graduação viria a ter no Brasil nas décadas seguintes.

Os governos anteriores foram perdendo força com o agravamento da dívida interna e externa do país e isto propiciou um movimento de reação entre os setores conservadores da sociedade (militares, alto clero da Igreja e organizações da sociedade civil), que culminou com o golpe de Estado de 31 de março de 1964. Sob o comando das forças armadas, foi instaurada uma ditadura militar no país, apoiada pelos Estados Unidos. Com a entrada significativa de capitais externos, atraídos também pela estabilidade política, os anos que se seguiram viram a economia crescer a taxas que chegaram a $10 \%$ ao ano, constituindo o que se chamou "milagre econômico brasileiro".

Esse crescimento só foi possível em função da exclusão de amplos segmentos da população das tomadas de decisão da política nacional, por meio de um processo de supressão das liberdades democráticas. No campo educacional, os militares adotaram a teoria econômica do "capital humano"16 para justificar o

\footnotetext{
${ }^{16}$ Esta teoria surgiu da preocupação em explicar os ganhos de produtividade gerados pelo "fator humano" na produção. Sua concepção é de que o trabalho humano, quando qualificado por meio da educação, é um dos mais importantes meios para a ampliação da produtividade econômica, e, portanto, das taxas de lucro do capital. Ela colabora com a ideia de que os investimentos em
} 
processo político autoritário que subordinou a educação à lógica econômica de modernização acelerada da sociedade brasileira, destacando que o papel a ser desempenhado pela educação seria o de maximizar a produtividade (FERREIRA; BITTAR, 2008).

Nesse período, houve uma sucessão de medidas relacionadas à reforma do sistema de ensino que desencadearam um novo momento de desenvolvimento da pós-graduação no Brasil.

No início dos anos de 1960, o primeiro marco regulatório da pósgraduação foi a Lei $n^{\circ} 4.024$, de 1961, que definiu genericamente os cursos que poderiam ser ministrados em instituições de educação superior, entre os quais estavam a graduação, a pós-graduação e os de especialização, aperfeiçoamento e extensão. Essa lei era genérica e deixava lacunas em relação a questões importantes da graduação e da pós-graduação. Quatro anos depois, o Parecer $n^{\circ}$ 977/65 do Conselho Federal de Educação (CFE), conhecido como Parecer Newton Sucupira, regulamentou as experiências de pós-graduação no país, reconhecendo-as como novo nível de ensino. O parecer instituiu os cursos lato sensu (especializações) e stricto sensu (mestrado e doutorado), baseados no modelo norte-americano, concebendo os cursos de mestrado e doutorado como níveis autônomos e independentes entre si. Também foram instituídas exigências para os pós-graduandos, como a conclusão de um número mínimo de disciplinas e a qualificação junto a uma banca e defesa pública de uma tese com presença de professor externo ao departamento.

As mudanças introduzidas na pós-graduação na década de 1960 não ocorreram isoladamente; elas têm um caráter sistêmico e respondem a um planejamento educacional operado por meio de um conjunto de reformas dos diferentes níveis em que se organizava o ensino no Brasil, que culminou com a Reforma Universitária de 1968 e com a Lei 5.692 de 1971, relativa ao ensino de $1^{\circ}$ e $2^{\circ}$ graus.

educação sejam determinados pelos critérios do investimento capitalista, uma vez que a educação é o fator econômico considerado essencial para o desenvolvimento. Fonte: Grupo de Estudos e Pesquisas "História, Sociedade e Educação no Brasil" (HISTEDBR). Disponível em: <http://www.histedbr.fae.unicamp.br/navegando/glossario/verb_c_teoria_\%20do_capital_humano. htm>. Acesso em: 08 nov. 2011. 
Em seu já clássico e fundamental estudo sobre a educação e as desigualdades sociais, intitulado Educação e Desenvolvimento Social no Brasil, Cunha (1978) analisa a política educacional pós-64 mostrando tratar-se de uma proposta que articulava medidas de contenção e de liberação.

As medidas de liberação ocorreram no ensino regular (ampliação da escolaridade obrigatória de quatro para oito anos) e no ensino não regular (iniciativas dirigidas à escolarização de alunos em idade fora da faixa própria para o ensino regular). Essas medidas tinham, segundo o autor, funções político ideológicas, referentes ao papel atribuído à educação como propulsora do desenvolvimento do país, e funções econômicas, relativas à formação de contingentes de trabalhadores em volume "apropriado" de formação e com hábitos de consumo compatíveis com o modelo econômico em vigor ${ }^{17}$.

As medidas de contenção foram direcionadas ao ensino médio e superior, e constituem a face complementar das medidas de liberação. A Lei 5540/1968, chamada Lei da Reforma Universitária, introduziu mudanças no ensino superior, como a departamentalização, o sistema de créditos e a extinção da cátedra, que permitiriam, a um só tempo, aprimorar os mecanismos de controle políticoideológico sobre a academia e absorver também parte da pressão das classes médias por vagas para seus filhos no ensino superior. No entanto, havia um limite no atendimento às novas demandas por ingresso ao ensino superior. Se atendidas plenamente, essas demandas resultariam num aumento significativo do gasto público com a expansão e manutenção deste ensino e em um número crescente de diplomados pressionando o mercado de trabalho. O governo buscou, então, duas saídas articuladas que envolviam o ensino médio e a pós-graduação.

Por um lado, buscou cercar o acesso ao ensino superior de uma barreira de contenção por meio da reforma do ensino médio, que envolvia a profissionalização compulsória dos alunos como forma de conter a demanda por matrículas em cursos de graduação, mediante a restrição das oportunidades de

\footnotetext{
${ }^{17}$ No capítulo em que trata das medidas de liberação adotadas pelo governo, Cunha faz interessante análise do papel do chamado "Exército Industrial de Reserva", que consistia em um contingente de trabalhadores fora do mercado de trabalho, cuja principal função seria desestimular as reivindicações por melhores salários dos profissionais na ativa. Os programas de alfabetização de massa implantados pelo governo contribuíam para o aumento desse exército. Ver Cunha (1978), capítulo 5, "Política Educacional: contenção e liberação".
} 
formação propedêutica e da oferta de um certificado de nível técnico. Por outro lado, e complementarmente, a institucionalização da pós-graduação, nesse período, tem a função de restabelecer o valor econômico e simbólico do diploma, agora em nível mais elevado, acessível apenas a uma parte seleta (em termos intelectuais e de renda) dos graduados.

Para Cunha (1978), havia um objetivo menos explícito e comprometido com a manutenção do ensino da pós-graduação como espaço da alta cultura e como privilégio de poucos. Em face do crescimento do número de portadores de diplomas de graduação, caberia à pós-graduação a função de discriminação social, pelo restabelecimento do valor econômico e simbólico do diploma de ensino superior:

\begin{abstract}
O ensino pós-graduado confere diplomas (de mestre e doutor) que trariam a marca da raridade que é o que lhes confere um alto valor, tanto econômico (elegibilidade para ocupações mais remuneradoras) quanto simbólico (atribuição de maior "quantidade" de prestígio). (CUNHA; 1978, p. 245).
\end{abstract}

A Lei da Reforma Universitária tratou da institucionalização da pósgraduação, definindo-a como modalidade de curso e indicando que caberia ao Conselho Federal de Educação (CFE) baixar normas para sua organização (BRASIL, 1968). Os objetivos principais da pós-graduação seriam os de formar pessoal de alta qualificação para empresas públicas e privadas e de estimular pesquisas que contribuíssem para o desenvolvimento do país. Além de buscar atingir os objetivos mencionados, o governo também percebia as potencialidades estratégicas dessa etapa avançada de formação de recursos humanos e buscou vincular o desenvolvimento científico e tecnológico com uma ação mais ampla de desenvolvimento econômico do país.

Alianças com lideranças científicas nacionais fizeram com que os pesquisadores e os programas de pós-graduação passassem a contar com o apoio financeiro das agências de fomento. Este apoio, e o empenho dos doutores e mestres que atuaram nesse período, designado por Saviani (2000) como "período heroico", fizeram com que a pós-graduação crescesse significativamente nos anos seguintes: se, em 1965, eram 38 os programas de pós-graduação reconhecidos, uma década depois totalizavam 429 (BALBACHEVSKY, 2005). 
$\mathrm{Na}$ análise do Cury (2005), a reforma do ensino superior, embora fosse centralizadora e tivesse ocorrido em um clima avesso ao diálogo, acertou ao definir a Universidade como instituição que se caracteriza pela indissociabilidade entre ensino, pesquisa e extensão. Também, nesse período, a pós-graduação se desenvolveu como a principal agência de qualificação de docentes e como elemento fundamental da criação de um sistema nacional de ciência e tecnologia. Naquele contexto, entre os governantes do período:

[...] a nossa fragilidade científica era vista mais como causa do "atraso" do que como consequência de uma dependência mais ampla e de uma exclusão secular em matéria de educação nacional, especialmente na escolarização básica. (CURY, 2005, p. 29-30).

\section{2.}

\section{Os Planos Nacionais de Pós-Graduação: do I ao IV PNPG}

A compreensão do processo de desenvolvimento da pós-graduação no Brasil requer o estudo dos Planos Nacionais de Pós-Graduação, documentos oficiais que registram os objetivos traçados para esse nível de ensino pelas instancias oficiais do governo e refletem o contexto político e econômico em que foram elaborados e divulgados.

Trata-se de seis PNPGs. No presente estudo, procuramos situar cada um dos planos nos diferentes contextos políticos e econômicos em que foram produzidos. Para fins de análise, dividimos a apresentação dos PNPGs em dois momentos.

No primeiro momento, e neste capítulo, apresentamos os planos mais antigos, elaborados entre 1974 e 1990.

Por sua vez, no segundo momento, os PNPGs mais recentes, elaborados para vigorar, respectivamente, nos períodos 2005-2010 e 2010-2020, serão apresentados no capítulo 4, que trata do contexto de produção de texto da política atual de pós-graduação.

Em meados da década de 1970, o número de cursos de pós-graduação havia crescido consideravelmente no país, mas sua oferta ainda ocorria de forma descentralizada, autônoma e sem planejamento. O governo do presidente Ernesto Geisel (1974/1979) buscou ordenar, centralizar e planejar o desenvolvimento da pós-graduação lançando o primeiro Plano Nacional de Pós-Graduação, com o 
objetivo de reorientar as atividades em âmbito nacional, oferecendo um conjunto de medidas e parâmetros a serem usados na gestão dos cursos, das Universidades e dos órgãos do governo federal envolvidos com esse nível de ensino. O I PNPG tinha natureza indicativa e buscava sintonizar os cursos de mestrado e doutorado com as necessidades de formação e desenvolvimento científico-tecnológico do país.

Desde o I PNPG (1975-1979) até o atual (PNPG 2010-2020), o Brasil teve seis Planos Nacionais de Pós-Graduação, sendo que o quarto plano foi discutido, mas não chegou a ser editado. Esses documentos, assim como as discussões que os antecederam e sucederam, vêm contribuindo com o planejamento, a expansão e a consolidação das atividades de pós-graduação no país.

O quadro 4 mostra as distintas versões dos PNPGs e suas diferenças formais, de estrutura e tamanho.

\section{Quadro 4: Características formais dos Planos Nacionais de Pós-Graduação}

\begin{tabular}{|c|c|c|c|c|}
\hline Plano & Vigência & $\begin{array}{c}\text { Número de } \\
\text { Tópicos }\end{array}$ & $\begin{array}{c}\text { Número de } \\
\text { Subtópicos }\end{array}$ & $\begin{array}{c}\text { Número } \\
\text { Páginas }\end{array}$ \\
\hline I PNPG & $\begin{array}{c}1975 / 1979 \\
(5 \text { anos })\end{array}$ & 4 & 11 & 56 páginas \\
\hline II PNPG & $\begin{array}{c}1982 / 1985 \\
(4 \text { anos })\end{array}$ & 6 & 0 & 15 páginas \\
\hline III PNPG & $\begin{array}{c}1986 / 1989 \\
(4 \text { anos })\end{array}$ & 6 & 0 & 23 páginas \\
\hline IV PNPG & $\begin{array}{c}\text { Discutido na } \\
\text { Década de } 1990\end{array}$ & - & - & $\begin{array}{c}\text { Não } \\
\text { oficializado }\end{array}$ \\
\hline $\begin{array}{c}\text { PNPG } \\
2005 / 2010\end{array}$ & $\begin{array}{c}2005 / 2010 \\
(5 \text { anos })\end{array}$ & 5 & 10 & 91 páginas \\
\hline $\begin{array}{c}\text { PNPG } \\
2011 / 2020\end{array}$ & $\begin{array}{c}2011 / 2020 \\
(10 \text { anos })\end{array}$ & 16 & 68 & 309 páginas \\
\hline
\end{tabular}

Fonte: Capes/PNPGs (1975-2011).

Observando o quadro 4, percebemos que a duração dos períodos de vigência dos planos, bem como o número de tópicos abordados em cada um deles variaram ao longo do tempo, o que pode ser explicado, pelo menos em parte, em função do contexto histórico em que cada um dos documentos foi gerado. 
Com exceção da elaboração do I PNPG, sob responsabilidade do antigo Departamento de Documentação e Divulgação do Conselho Nacional de PósGraduação, os demais planos foram elaborados pela Capes.

\subsection{1.}

\section{Plano Nacional de Pós-Graduação (1975/1979)}

O I Plano Nacional de Pós-Graduação foi aprovado quando a ditadura militar começava a perder sua legitimidade no Brasil. A insatisfação era fruto da situação econômica, de recessão e inflação crescentes. O governo viu-se obrigado a atenuar a repressão e a buscar o apoio da sociedade civil, adotando o discurso da necessidade de desenvolvimento econômico aliado à distribuição de renda. Nesse contexto, a educação toma lugar de destaque, por ser considerada propulsora do desenvolvimento do país e da ascensão social dos indivíduos.

O regime militar deu à pós-graduação um caráter de urgência, em razão do ambicioso projeto de elevar o país à condição de potência mundial. O ensino stricto sensu foi pensado com o propósito explícito de promover a pesquisa na Universidade brasileira (FERRARO, 2005; LIRA, 2010; VAROTTO, 2007) e o I Plano Nacional de Pós-Graduação foi elaborado para orientar essas mudanças. Já na Introdução, o I PNPG apontava que as atividades de pós-graduação estavam assumindo uma importância estratégica para o país, pela via da formação de pessoal altamente qualificado. O documento estava composto de três partes principais: "Análise da Evolução da Pós-Graduação no Brasill”; "Objetivos e Diretrizes Gerais"; e "Programas e Metas de Expansão".

No tópico "Análise da evolução da pós-graduação” encontramos uma descrição do processo de crescimento da pós-graduação e a sinalização de pontos problemáticos, como a instabilidade e a fragilidade institucional de suas atividades, em geral realizadas por iniciativa de professores e pesquisadores que lançavam mão de recursos externos ao orçamento das Universidades. Estes grupos, impregnados pela cultura catedrática, adotavam procedimentos administrativos próprios, o que gerava conflitos nas Universidades e falta de controle no nível federal. Diante desse quadro, e condizente com a racionalidade técnica vigente, o Plano alertava para a necessidade de planejamento e articulação 
dessas atividades, com vistas à superação dos principais problemas diagnosticados, relativos não apenas à instabilidade das atividades de pósgraduação, mas também, ao baixo desempenho dos cursos e ao seu crescimento insuficiente e concentrado nas grandes capitais.

Na seção "Objetivos e diretrizes gerais", o Plano determinava que cabia à pós-graduação formar professores para o magistério universitário, formar pesquisadores para o trabalho científico e preparar profissionais de nível elevado para o mercado de trabalho. Para tal, foram eleitas três diretrizes que orientariam essas iniciativas: institucionalizar o Sistema Nacional de Pós-Graduação (SNPG), garantindo seu financiamento; elevar os padrões de desempenho e racionalizar a utilização dos recursos; e, planejar sua expansão. O Plano conceitua cada diretriz e as medidas a serem tomadas em cada nível institucional, determinando o prazo de cinco anos para a implantação das mesmas. A partir desse momento, termos como "racionalidade administrativa", "informações estatísticas", "elaboração de projetos", entre outros, estarão diretamente relacionados com a gestão dos cursos e programas.

Em "Programas e Metas de Expansão", foram definidas as linhas gerais de expansão projetadas para o quinquênio 1975/1979, determinando-se como meta a titulação de 16.800 mestres e 1.400 doutores no período, além da ampliação da capacidade de atendimento de 7.000 para 11.700 vagas anuais de mestrado e de 500 para 1.200 vagas anuais de doutorado. Para isso, o governo propôs três programas interdependentes: (1) concessão de bolsas de estudo para alunos em tempo integral; (2) programas institucionais de capacitação de docentes; e (3) admissão de docentes de maneira regular e programada pelas instituições. Esses três programas, apesar de independentes, demarcam aspectos políticos importantes para a pós-graduação, que, nos anos seguintes, iria passar por uma fase de consolidação e expansão (SAVIANI, 2000).

No I PNPG, lançado no momento do enfraquecimento do regime militar, fica evidenciada a intenção do governo de coordenar e controlar melhor as atividades de pós-graduação, determinando fontes de financiamento, as atribuições dos diferentes entes do sistema, as metas a serem alcançadas e a necessidade de avaliação. A análise do I PNPG é significativa, pois contextualiza os desafios da gestão de cursos de pós-graduação no início do estabelecimento 
dessas atividades no Brasil e nos ajuda a compreender melhor questões ainda presentes nos dias atuais.

O documento foi pautado pela lógica da racionalidade técnica que vigorou ao longo do governo militar, que entendia os "técnicos" como a melhor solução para a administração do Estado. As ações administrativas, nesse contexto, eram pautadas por questões econômicas em detrimento dos aspectos políticos e sociais (FERREIRA e BITTAR, 2008).

Ao longo do documento, foi possível observar a autonomia como uma característica muito forte dessas atividades, que começaram por iniciativa de docentes catedráticos e com fontes diferenciadas de recursos. Eram os próprios docentes que organizam os cursos e a autonomia lhes proporcionava independência e flexibilidade em relação ao governo e à Universidade, o que resultava em "procedimentos administrativos próprios". Se, por um lado, isso era positivo, por outro, o documento argumentava que não havia estabilidade nos cursos nem tampouco regulamentação, padronização ou qualquer parâmetro que permitisse a avaliação dos mesmos. Buscando alterar esse quadro, o I PNPG introduziu um tipo de racionalidade técnica, baseada em planejamento e avaliação, que, ao longo do tempo, foi capilarizando a pós-graduação e a gestão dos programas.

Embora vários estudiosos reconheçam que esta política da Capes impulsionou o desenvolvimento e a qualidade desse nível de ensino, o controle gerado por essa racionalização encontra, até hoje, resistências nos gestores e docentes dos programas de pós-graduação, que iniciaram suas atividades de forma tão livre.

\subsection{2.}

\section{Plano Nacional de Pós-Graduação (1982/1985)}

No início da década de 1980, o país enfrentava um período de recessão em virtude do enfraquecimento do modelo econômico do regime militar, além da transição entre o regime autoritário e o regime democrático, o que incluía a revogação do Ato Institucional 5 (1978), a aprovação da Lei da Anistia (1979) e o fim do bipartidarismo (1980). 
O II PNPG foi implantado nesse período e manteve como objetivo da pósgraduação a formação de recursos humanos especializados, mas focou as orientações na busca da qualidade, por meio de racionalização do uso dos recursos e do aprimoramento da avaliação (SANTOS; AZEVEDO, 2009).

O segundo Plano foi bem mais modesto que o primeiro em seus objetivos e diretrizes, e não apresentou nenhum programa governamental de apoio à pósgraduação ou meta de crescimento a ser alcançada. O foco esteve colocado no tema da qualidade e na mensagem de que era preciso tornar mais eficiente o sistema já existente. O documento constata problemas estruturais que persistiam nos cursos stricto sensu, como a dependência de recursos extraorçamentários, a instabilidade empregatícia, a irregularidade dos financiamentos, a escassez de técnicos e de pessoal de apoio, o número insatisfatório de professores para as atividades de pesquisa, ensino e orientação, propondo a flexibilização da formação e reforçando a exigência de qualidade.

Segundo o Plano, o mestrado e o doutorado não seriam necessariamente as únicas formas de capacitar o magistério, sendo igualmente importante, em algumas áreas, a atualização do corpo docente em cursos de aperfeiçoamento e especialização, a leitura dos periódicos especializados, a participação em eventos científicos e a elaboração de textos para publicação. Essa flexibilização na exigência de formação relaciona-se com a crise econômica e a escassez de recursos que o país atravessava.

O Plano aborda o tema da qualidade que, segundo o documento, vinha diminuindo em função da expansão quantitativa do sistema, ao mesmo tempo em que indica a responsabilidade das instituições governamentais, especialmente das agências de fomento, de criar e manter condições essenciais para a produção acadêmica, cobrando, também, sua efetiva realização. Naquele momento, a avaliação dos cursos de pós-graduação realizada pela Capes, instituída desde 1976 com o objetivo de gerar parâmetros para orientar a distribuição de bolsas de estudo, ainda não tinha alcançado a dimensão dos dias atuais (BITTAR, 2005; SANTOS; AZEVEDO, 2009).

Além da busca da qualidade, o II PNPG define como prioridades para a pós-graduação a adequação do sistema às necessidades do país e a coordenação das ações das diferentes instâncias governamentais. Para aumentar a qualidade do 
sistema de pós-graduação, o documento considerava necessária a realização de um acompanhamento mais eficaz dos recursos, além do aperfeiçoamento dos sistemas de informação e avaliação, com a finalidade de dar apoio àqueles que fossem considerados programas bons e promissores.

O II PNPG refletiu o momento político e econômico de transição democrática e de crise financeira, limitando-se a orientar as atividades desse nível de ensino no sentido de otimizar os recursos existentes, melhorar a qualidade e flexibilizar as possibilidades de formação. Olhando do ponto de vista dos gestores de programas, a principal mensagem é que eles deveriam contribuir para a melhoria da qualidade dos cursos, aproveitando de forma mais eficiente os recursos, sob a pena de não conseguir novas verbas para a continuidade das atividades.

\subsection{3.}

\section{Plano Nacional de Pós-Graduação (1986/1989)}

Em 1986, no governo de José Sarney, foi publicado o III PNPG. O Brasil entrava na terceira etapa da transição democrática, na qual os militares deixavam de deter o papel principal no processo, sendo substituídos pelos políticos civis com a participação dos setores organizados da sociedade (KINZO, 2001).

A Capes consultou a comunidade científica para a elaboração do documento, que expressava o desejo de conquista da autonomia do país, vigente no âmbito nacional. Aos objetivos dos planos anteriores foram acrescentadas tanto a necessidade de institucionalização e ampliação da pesquisa nas Universidades como de integração da pós-graduação ao Sistema Nacional de Ciência e Tecnologia (SNCT) e ao setor produtivo.

Ao analisar a evolução e situação da pós-graduação, o plano constata, ao lado dos avanços, a persistência de problemas como a baixa produtividade e a heterogeneidade na qualidade produzida pelas diferentes áreas de conhecimento e regiões do país, a carência de pesquisadores com formação interdisciplinar e o elevado tempo médio de titulação. Com o intuito de fazer face a essa situação, foram apresentadas medidas para a expansão da base científica nacional, que envolviam: a manutenção da qualidade dos cursos considerados bons e excelentes 
pela Capes, investimentos para melhoria da produtividade, consolidação dos cursos bons e aperfeiçoamento dos cursos que apresentassem problemas, estímulo à abertura de doutorados e à criação de novos programas de mestrado, aperfeiçoamento e expansão do sistema de bolsas de estudo, fomento à capacitação no exterior e melhoria de infraestrutura para as atividades de pósgraduação nas Universidades.

As diretrizes gerais do documento fazem menção à necessidade de estimular as atividades de investigação científica e tecnológica, de consolidar as instituições universitárias e de pós-graduação, de garantir recursos para a infraestrutura e o financiamento de projetos de pesquisa. Mencionam também a importância da participação da comunidade científica na coordenação, no planejamento e na execução das atividades de pós-graduação, além de estimular a diversidade de concepções e organizações e de assegurar condições ao estudantebolsista para se dedicar integralmente à pós-graduação.

O III PNPG traz ainda um tópico destinado apenas às estratégias a serem seguidas pelos vários órgãos e instituições que compõem o SNPG para o alcance dos objetivos apresentados. Trata-se do aperfeiçoamento do sistema de avaliação da pós-graduação e das ações de fomento, da promoção de maior interação entre graduação/pós-graduação/programas e centros de pesquisa, da melhoria do financiamento de bolsas, revistas científicas e aquisição de periódicos, e, ainda, do apoio aos grupos emergentes de pesquisa, aos mestrados de bom nível, à criação de cursos de doutorado e de novos programas, e à formação de recursos humanos na Amazônia.

Diante das metas e diretrizes apresentadas, é possível observar que a proposta do III PNPG tem um tom mais propositivo e focado na formação de recursos humanos para o desenvolvimento científico e tecnológico. Todas as medidas indicadas no III PNPG, relativas à expansão da base científica nacional, às atividades de investigação científica e tecnológica e ao aperfeiçoamento do sistema de avaliação e de fomento, foram de fundamental importância para o desenvolvimento da pós-graduação brasileira e contribuíram para seu aprimoramento.

Com o avanço da redemocratização e o desenho de novas configurações institucionais no país, o III PNPG teve como objetivo principal institucionalizar e 
ampliar as atividades de pesquisa e pós-graduação. O documento trata de questões mais diretamente relacionadas ao trabalho de gestão das instituições, indicando medidas específicas para a institucionalização da pesquisa nas Universidades, a saber: destacar, nos orçamentos das instituições, verbas para a pós-graduação; reestruturar a carreira docente no sentido de valorizar a produção científica; planejar a ampliação dos quadros universitários; institucionalizar a atividade sabática; e estimular a autoavaliação dos cursos. Trata-se de orientações que precisam ser seguidas no interior das Universidades e em relação às quais os gestores de programas de pós-graduação têm um papel importante.

\subsection{4.}

\section{Plano Nacional de Pós-Graduação}

Ao longo dos anos 90, e até meados dos anos 2000, não houve a formalização de um novo plano nos moldes dos anteriores. A despeito disso, a pós-graduação brasileira atravessou um período de mudanças significativas em suas políticas, influenciado pelo contexto da Reforma do Estado. Com a redemocratização, o Brasil recuperou suas bases federativas e, ao longo dos anos 90, implantou um extensivo programa de descentralização, apoiado pela população e pelos movimentos sociais, que associavam o federalismo e a descentralização à negação do autoritarismo e da centralização deixada pela ditadura militar.

Somado a isso, em virtude do contexto internacional de globalização e neoliberalismo, ganhou força, por meio dos organismos internacionais, um discurso que defendia que o problema da educação não era de ordem quantitativa, em termos de vagas, recursos etc., mas, sim, de ordem qualitativa, relacionada com a má aplicação dos recursos financeiros, com a ineficiência etc. Ao longo da década de 1990, portanto, essas ideias deram forma ao processo de Reforma do Estado, que tinha como características a descentralização da administração e a instalação de mecanismos de controle por parte do governo federal (CASTRO; MENEZES, 2002).

No que se refere às políticas educacionais, houve o fortalecimento de diretrizes relacionadas à gestão democrática, à descentralização de recursos, à 
autonomia dos gestores e à avaliação educacional. No âmbito da pós-graduação, ao longo dos anos 90, a Capes promoveu discussões para a construção do IV $\mathrm{PNPG}^{18}$. As discussões realizadas nesses encontros e as publicações resultantes deles se constituíram no espaço em que a pós-graduação foi pensada nos anos em que não houve a vigência de um novo PNPG. Algumas redações preliminares do Plano circularam exclusivamente entre os membros da diretoria da Capes. Embora o órgão tenha em seus arquivos um documento que consolida o IV PNPG, datado de 1998, este plano, por questões orçamentárias e de falta de articulação entre as agências, não chegou a ser oficializado (BRASIL, 2003).

A maior parte dos debates ocorreu durante os dois governos de Fernando Henrique Cardoso (FHC) e girou em torno de dois princípios básicos: autonomia institucional e flexibilização. Esses princípios estavam alinhados com o contexto político da reforma, que defendia a descentralização e a diminuição da participação da União na gestão do ensino, e indicava que a Universidade deveria assumir a responsabilidade pela gestão de seu Sistema de Pós-Graduação. A flexibilização era identificada, basicamente, com o apoio a novos tipos de mestrados, como os interdisciplinares e os profissionais. Documentos gerados ao longo do processo apontaram lacunas no sistema, entre as quais se destacavam a perda de quadros atuantes da pós-graduação, a infraestrutura insuficiente e a permanência do desequilíbrio da oferta de cursos entre as regiões brasileiras e entre as diferentes áreas do conhecimento (SANTOS; AZEVEDO, 2009; BRASIL, 2010).

Num período em que não houve vigência formal de um PNPG, muitas ações foram implantadas pela Capes, entre elas a instituição de comissão de bolsas para estabelecer critérios de concessão e acompanhar o desempenho do bolsista; a determinação de um prazo máximo de vigência da bolsa e a inclusão de um tempo médio de titulação na avaliação; regulamentação dos mestrados

\footnotetext{
${ }^{18}$ A Comissão Mista Capes/CNPq (BRASIL, 2003), que elaborou documento preliminar para a construção do PNPG 2005-2010, apontou os principais acontecimentos articulados pela Capes em torno da elaboração do IV PNPG: distribuição junto à comunidade acadêmica do documento Discussão da Pós-Graduação Brasileira (1996); realização de um Seminário Nacional para discussão das propostas (1996); edição especial do Infocapes com sínteses dos relatores do seminário; recebimento do Documento Final consolidado (1997); seminário Pós-Graduação: enfrentando novos desafios (2000); resultados do Seminário de 2000 publicados em número especial do Infocapes (2001).
} 
profissionais; novas formatações de cursos de pós-graduação (cursos em rede ou em caráter interinstitucional); ampliação da cooperação internacional; criação do Portal de Periódicos da Capes, entre outras (SANTANA; MARTINS, 2012). Todas essas mudanças foram determinantes em relação à consolidação e ao aprimoramento do Sistema Nacional de Pós-Graduação.

Foi ainda nesse período que a Capes formulou um novo modelo de avaliação, introduzido para o biênio 1996/1997, no qual o foco da política deixou de ser a docência, passando a ser a pesquisa e a produção científica. Esse novo modelo preservou a autoridade dos comitês (avaliação por pares), adotando um conjunto de indicadores e regras mais claras a serem observadas. Veremos essa questão em profundidade no próximo capítulo, que trata da Política Brasileira de Pós-graduação. 


\section{4.}

\section{Política de Pós-Graduação: influências internacionais e nacionais reveladas no contexto de produção de texto}

De acordo com os objetivos da pesquisa, a partir desse momento, vamos focar nossa análise nos aspectos da Política Brasileira de Pós-graduação relacionados mais diretamente ao período em que ocorreram as avaliações e os avanços de nota dos Programas selecionados, ou seja, a primeira década do século XXI.

O período em tela, que abarca os resultados das avaliações trienais 2001, 2004, 2007 e $2010^{19}$, foi marcado por mudanças no contexto internacional e nacional que desencadearam a introdução de um novo modelo de avaliação dos programas stricto sensu pela Capes. As mudanças ocorridas no contexto político, econômico e educacional se revelaram nos documentos da Política de PósGraduação, notadamente nos PNPGs mais recentes e nos documentos da Área da Educação.

Como foi apresentado no capítulo 2, do ponto de vista metodológico, optamos pela abordagem do ciclo de políticas proposto por Stephen Ball, que envolve o contexto de influência, o contexto da produção de texto e o contexto da prática, incluindo a dimensão dos resultados ou efeitos. Neste capítulo, vamos analisar como os contextos de influência internacional e nacional se revelam no contexto da produção de texto da Política de Pós-Graduação.

\section{1.}

\section{Contextos de influência internacional: influências históricas, político- econômicas e educacionais na pós-graduação brasileira}

De acordo com Mainardes (2006), o contexto de influência proposto por Ball é aquele no qual as políticas são iniciadas e o discurso político é construído e adquire legitimidade. Essas influências estão inter-relacionadas e podem ser locais, nacionais e internacionais. Nesta seção, vamos analisar as principais

\footnotetext{
${ }^{19}$ As avaliações referem-se, respectivamente, aos anos de: 1998 a 2000; 2001 a 2003; 2004 a 2006; 2007 a 2009.
} 
influências internacionais da pós-graduação brasileira, observando como as mesmas se refletem no contexto nacional e nos programas selecionados. $\mathrm{O}$ estudo desse contexto nos permitiu observar o grau de sintonia da Política de PósGraduação Brasileira, na qual a avaliação coordenada pela Capes tem papel determinante, com tendências identificadas no cenário internacional.

As influências internacionais na pós-graduação brasileira têm raízes históricas. O modelo brasileiro de pós-graduação é híbrido, representando um ajuste entre características do modelo americano (profissional) e do modelo europeu (tutorial) às particularidades da educação brasileira. Verhine (2008) aponta que a Universidade brasileira foi originalmente baseada no modelo europeu, especialmente o francês, que era organizado em torno de professores catedráticos. A reforma universitária de 1968, entretanto, modelou a pósgraduação com base na experiência dos Estados Unidos (EUA), que tem como centro o departamento e um sistema de curso/crédito ${ }^{20}$.

Em consequência, a educação pós-graduada no país resultou da combinação dos modelos americano e francês, ajustados às nossas circunstâncias. Nosso mestrado aproximou-se mais do modelo americano de $\mathrm{PhD}$, que enfatiza um currículo estruturado e a conclusão do curso com uma dissertação, enquanto o doutorado ficou mais próximo do modelo europeu de aprendizagem, apresentando uma abordagem mais tutorial.

Ao longo das décadas de 1980 e 1990, no âmbito político e econômico mundial, ocorreram mudanças como a diminuição das fronteiras nacionais, o crescimento de conglomerados econômicos e o aumento da competitividade tecnológica, que resultaram em alterações nas estruturas institucionais dos Estados. Essas transformações afetaram as instituições e trouxeram mudanças para a Universidade, que se tornou um instrumento de produção, sobretudo, na área de Ciência, Tecnologia e Inovação (CT\&I).

Convergindo com as mudanças na economia mundial, no mesmo período, teve grande importância o chamado "Processo de Bolonha". No final do século $\mathrm{XX}$, a educação superior europeia apresentava alguns problemas, tais como a falta de compatibilidade entre os sistemas universitários dos diferentes países que integravam a União Europeia, a baixa integração das Universidades estatais com

\footnotetext{
${ }^{20}$ Para mais informações sobre a Reforma Universitária, ver capítulo 3.
} 
as empresas e a sociedade, o reduzido financiamento de natureza privada, a rigidez estrutural da Universidade e, ainda, problemas de eficácia e eficiência acadêmica (HORTALE; MORA, 2004).

Esse conjunto de problemas fazia com que educação superior europeia tivesse uma menor atratividade e competitividade em nível internacional, quando comparada com a oferecida pelos EUA e o Japão, por exemplo. Para enfrentar essas questões, 29 ministros da educação da Europa assinaram, em 1999, a "Declaração de Bolonha", que deu início a um processo de renovação das Universidades dos países signatários.

Trata-se de um processo iniciado por dirigentes políticos que tinham por objetivo aumentar a competitividade, melhorar a adaptação do ensino ao mercado de trabalho e desenvolver a mobilidade estudantil. Para atingi-los, foram propostas como metas o estabelecimento de um sistema uniforme de créditos; programas de intercâmbio; mecanismos de cooperação universitária; e organização do sistema de graus em dois ciclos (graduação e pós-graduação). Segundo Erichsen (2007), a garantia da qualidade foi um valor central na orientação do Processo de Bolonha. Isso fez com que a avaliação e o credenciamento ganhassem cada vez mais importância como meios para orientar e garantir a qualidade do ensino superior.

O Brasil foi influenciado pelo cenário internacional, com consequências para nosso ensino superior e para a pós-graduação. Nesse período, o uso da avaliação como instrumento da gestão educacional de todos os níveis de ensino expressa uma das novas formas de regulação adotadas pelo Estado brasileiro na definição, condução e execução da ação pública. Em diversos países, ao longo das décadas de 1980 e 1990, as iniciativas de Reforma do Estado representaram a tentativa de adaptação às novas condições da economia mundial e às restrições fiscais impostas pela crise internacional. Parte desses países apoiou suas reformas em novas doutrinas que ficaram conhecidas como "novo gerencialismo público" (SOUZA; CARVALHO, 1999).

De forma sucinta as principais características dessa reforma incluem, segundo Castro (2008):

a) a descentralização/desconcentração das atividades centrais para as unidades subnacionais; b) a separação dos órgãos formuladores e executores de políticas públicas; c) o controle gerencial das agências autônomas, que passa a ser realizado levando em consideração quatro tipos de controles, quais sejam: 
controle dos resultados, a partir de indicadores de desempenhos estabelecidos nos contratos de gestão, controle contábil de custos, controle por quase-mercados ou competição administrada, e controle social; d) a distinção de dois tipos de unidades descentralizadas ou desconcentradas (as agências que realizam atividades exclusivas do Estado e os serviços sociais e científicos de caráter competitivo); e) a terceirização dos serviços e f) o fortalecimento da alta burocracia. (p. 392).

Nos países em desenvolvimento, incluído o Brasil, são identificados dois estágios na Reforma do Estado. O primeiro se desenvolveu entre a década de 1980 e o início dos anos 1990 e teve como objetivo a racionalização dos recursos fiscais. Voltado para a abertura dos mercados, para a desregulamentação e a privatização, o primeiro estágio foi realizado principalmente pelo governo federal e pelos governos estaduais. Como vimos, em sintonia com essa tendência, o II e o III PNPG, publicados nos anos 80, já introduziam a ideia de racionalização dos recursos e necessidade de se aferir a qualidade da pós-graduação.

No segundo estágio, a partir de meados dos anos de 1990, prevaleceram novos objetivos mais claramente ligados à nova gestão pública, como a eficiência dos serviços públicos e sua efetividade, a democratização, com o envolvimento da comunidade nas decisões relativas às ações públicas, e a descentralização para as esferas subnacionais das responsabilidades de provisão da infraestrutura e dos serviços sociais. Este estágio teve foco na reconstrução das capacidades administrativas e institucionais do Estado, caracterizando-se pela busca tanto de instrumentos que permitissem aumentar o desempenho dos organismos públicos na prestação dos serviços ao cidadão, como de incentivos que aumentassem os estímulos para a cooperação e execução sustentada das decisões governamentais. Para Souza e Carvalho (1999) e Melo (2005), o segundo estágio da reforma do Estado, diferentemente da reforma anterior, é mais sensível do ponto de vista político porque abarca decisões que afetam mais significativamente as esferas locais e as políticas sociais.

Assim, no segundo estágio, a reforma passa a ser vista como um processo que se destina não apenas a apoiar as ações voltadas para o governo, mas que também envolve outros atores sociais e políticos, por meio do estímulo à participação das esferas subnacionais, do setor privado (lucrativo ou não) e da sociedade civil na formulação e realização de políticas. As reformas do segundo estágio, ao contrário das primeiras, passam a ser definidas em razão dos resultados a serem atingidos, o que envolve tipicamente a eficiência administrativa, a 
eliminação da pobreza e a criação de ambientes regulatórios adequados e estáveis (MELO, 2005).

No Brasil, a agenda das reformas de primeiro estágio foi introduzida por Collor de Mello, por meio de algumas privatizações, enquanto o governo Itamar Franco introduziu o principal elemento de sustentação e justificação das reformas: o Plano Real. Já o primeiro mandato do governo Fernando Henrique Cardoso (FHC) deu o formato conceitual à reforma, principalmente por meio do Ministério da Administração e Reforma do Estado - MARE (BRASIL, 1995). As propostas do MARE voltam-se para o segundo estágio das reformas, centrando-se: a) na busca da melhoria da atuação burocrática; b) na separação das atividades de regulação e de execução, o que terá efeitos sobre as esferas locais, e c) na ampliação da efetividade, universalização e democratização dos serviços públicos sociais. Trata-se da passagem para um modelo de Estado que substitui o controle direto e a priori dos processos por um controle indireto e a posteriori, com foco nos resultados.

Assim, a avaliação da educação ganhou centralidade na década de 1990 no Brasil porque mudaram as formas e os instrumentos utilizados pelo Estado para intervir na educação e no modo de assegurar seu papel na definição, condução e execução da política e da ação pública educacional. Ou seja, mudaram os modos de a política social pública contemplar o tema da avaliação porque também se transformaram as formas estatais de regulação, os modos como são produzidas e aplicadas às regras que orientam a ação dos atores; os modos como esses mesmos atores se apropriam delas e as transformam (BARROSO, 2005).

A alteração do processo de avaliação de programas de pós-graduação pela Capes, ao longo da década de 1990, situa-se nesse contexto e acompanha a tendência mundial de investimentos em CT\&I. No Brasil, ocorre uma nova expansão da educação superior e também da pós-graduação. A Universidade brasileira foi definida como um lócus privilegiado da produção de CT\&I e o Estado, com a mediação institucional da Capes, busca instaurar um sistema de pesquisa e pós-graduação mais produtivo, regulado e flexível, estabelecendo mudanças nesse sentido (SILVA JÚNIOR; FERREIRA; KATO, 2013).

A principal mudança é a adoção de um novo modelo de avaliação da pósgraduação, centrado na pesquisa e na produção científica (HORTA; MORAES, 
2005), para estabelecer os padrões de qualidade dos cursos e para financiá-los de acordo com as notas obtidas nas avaliações trienais. Programas com maiores notas recebem mais apoio financeiro, que se materializa tanto em recursos para despesas do programa, quanto em bolsas de estudo para os alunos. Além disso, a Capes também oferece bolsas de estudo no exterior e publica editais para atingir objetivos estratégicos, como a internacionalização da pesquisa, a priorização de áreas específicas, o equipamento de laboratórios etc.

Segundo Oliveira e Almeida (2011), o Estado brasileiro, influenciado pelas mudanças do cenário político-econômico internacional e pelo Processo de Bolonha, passa a atuar como órgão regulador, buscando assegurar a qualidade e eficiência do sistema de ensino, por meio da avaliação:

\begin{abstract}
A avaliação, nesse processo, torna-se um instrumento importante. No contexto das reformas da educação e no espaço da pós-graduação no Brasil, a opção clara da Capes, naquele momento, foi construir as reformas pela via da avaliação. É possível perceber que inúmeras providências, gradativamente, foram tomadas no sentido de superar dificuldades inerentes ao modelo de avaliação adotado. (ibid., p. 43).
\end{abstract}

Verhine e Freitas (2012) também identificam essa tendência, constando que, nas últimas décadas, as mudanças introduzidas no Estado, atribuem à avaliação um papel central na organização das reformas educacionais. Essas reformas relacionam-se a grandes metas sociais e econômicas, definidas pelo processo de globalização, que amplia e eleva os padrões de produção de ciência e tecnologia para aumentar a competitividade internacional entre países.

Entrevistado em nossa pesquisa por ter ocupado o cargo de Coordenador da Área da Educação na Capes no período 2004-2006, o professor Verhine lembra ainda outras experiências no país que espelham tendências internacionais, tais como a adoção do modelo de mestrado profissional nos anos 90, a ênfase na pesquisa na pós-graduação, a atual ênfase na inovação, a busca de padrões internacionais de excelência, e ainda, o intercâmbio entre docentes e discentes do país e do exterior.

Verhine adverte, entretanto, que atualmente não vê interferência estrangeira direta na Política de Pós-Graduação Brasileira, embora o contexto internacional a impacte, em razão do objetivo de melhorar os programas de pósgraduação e de adequá-los aos padrões internacionais de produção acadêmica e de pesquisa. Além disso, alerta sobre a dificuldade de se perceber com clareza até 
que ponto questões internacionais influenciam a pós-graduação brasileira, uma vez que nem sempre é possível separar claramente o que é devido à dinâmica interna e o que é fruto de influências externas:

\begin{abstract}
Não tem estrangeiro interferindo diretamente, mas o que acontece lá fora, evidentemente, eu devo enfatizar isso, impacta [a pós-graduação brasileira] no sentido de sempre estar buscando, de certa forma, melhorar os seus programas no cenário internacional. [O país] sabe que tem que adotar as políticas e os padrões internacionais no sentido de enfatizar o intercâmbio internacional e no sentido de enfatizar a pesquisa. Hoje em dia, ter uma nova inovação, e de novo, essa preocupação com a inovação também tem interferências que vem de fora porque é lá fora também que se está enfatizando a inovação. Então, muitas dessas tendências da Política de Educação Superior Brasileira, evidentemente, são tendências que espelham tendências internacionais. Até que ponto eles são realmente devido aos casos internacionais, é difícil dizer, porque tem uma dinâmica interna também. E você não pode se apressar para falar facilmente o que é uma dinâmica interna e o que vem de fora. Mas eu tenho a impressão que, evidentemente, em relação ao que vem de fora e o que vem de dentro do Brasil, que sempre que o Brasil quer subir no cenário internacional em termos de qualidade dos programas, em termos de conceituação de seus programas, tem esta interferência no sentido de querer utilizar padrões internacionais e modelos internacionais. O exemplo é o mestrado profissional, o exemplo é o próprio modelo do mestrado e do doutorado, a própria ênfase na pesquisa da pósgraduação, tudo isso, evidentemente, é decorrente de influências internacionais. (VERHINE, 23/04/2013).
\end{abstract}

As observações de nosso entrevistado vão ao encontro das de Ball (1998), para quem as influências internacionais são submetidas a processos interpretativos, sendo recontextualizadas e reinterpretadas pelos Estados-Nação. Assim, de acordo com a abordagem do contexto de influência, é possível perceber, ao se investigar uma política, que há presença de influências globais/ internacionais, assim como de influências nacionais e locais, cujos elementos são reinterpretados e recontextualizados através de interações dialéticas. Segundo Ball, a:

[...] maior parte das políticas são constituídas de montagens apressadas, de ensaios de tentativa e erro, que são retrabalhadas, remexidas, temperadas e modificadas através de complexos processos de influência, de produção de textos de disseminação e, em última análise, de recriação no contexto da prática. (1998, p. 132).

Verhine chama a atenção para os padrões de excelência internacionais que se busca atingir. Os coordenadores entrevistados também mencionaram a busca do padrão de excelência internacional e a atenção dada à inserção internacional 
em seus programas, em virtude de a Capes considerar essas questões como exigências para os programas de excelência.

Os programas tornam-se candidatos a programas de excelência se, entre outras coisas, atenderem a exigência de apresentar desempenho equivalente ao dos centros internacionais de excelência. Para isso, a Capes analisa indicadores de inserção internacional, como publicação de padrão internacional (periódicos A1 e A2 e livros L4); intercâmbios científicos; participação em congressos internacionais; convênios com instituições estrangeiras; doutorados no exterior etc., conforme descrito no "Relatório de Avaliação 2010-2012/ trienal 2013" no trecho que trata da definição dos programas de excelência.

Os principais indicadores de tal excelência são a produção científica veiculada tanto em periódicos indexados quanto em livros - principal forma de expressão da produção da área no âmbito nacional e internacional; a participação em redes institucionais de pesquisa; intercâmbio de docentes e discentes; o potencial de formação de pesquisadores com perfil compatível com os dos centros de excelência no exterior; a capacidade de nucleação de atividades de pesquisa nas áreas do programa; e a inserção social. (CAPES, 2013b, p. 39).

Essas exigências fazem com que haja maior circulação das ideias que são discutidas em âmbito internacional, maior intercâmbio acadêmico de professores e estudantes e, principalmente, a busca por uma produção acadêmica condizente com os padrões estabelecidos internacionalmente.

Segundo Ball (2004), a busca de padrões internacionais está relacionada ao contexto de performatividade, oriundo da relação que se estabelece entre globalização e educação. No entanto, Ball ressalta que as coisas não são "tão simples e tão nítidas assim", já que as tendências têm ritmos diferentes em lugares diferentes, afirmando que ações se conciliam para criar um senso comum para a política, um discurso político internacional. Em razão disso,

Não é mais possível ver as políticas educacionais apenas do ponto de vista do Estado-Nação: a educação é um assunto de políticas regional e global e cada vez mais um assunto de comércio internacional (ibid., p.1108).

Nossos entrevistados mencionaram a atenção dada pelos seus programas à internacionalização, especialmente por ser uma exigência para a conquista da "excelência":

No nosso caso, por exemplo, como estamos no início desse processo da nota 6, [a internacionalização] aparece para a gente como algo prioritário: o reforço, a ampliação e a consolidação dos convênios 
internacionais. E a gente está apostando muito nisso porque isso é o que diferencia os programa 6 e 7 dos programas 5, por exemplo, então como a gente é um "6" recente, a gente está atento para consolidar isso. (Coordenador A - PUCRS).

[Precisei dar mais atenção] à internacionalização, porque a gestão anterior tinha iniciado alguns projetos, mas nenhum tinha sido concretizado. Então eu peguei "o boi pelo chifre". Como o Programa já estava mais orgânico, foi [priorizada] a internacionalização, em todas as frentes: desde sistematizar; incentivar; fazer acordos com Universidades; colocar o Programa nesse doutorado latino-americano realmente; fazer as seleções, os editais de seleção [...] foi tudo na minha coordenação. (Coordenador B - UFMG).

Bourdieu (1983a) nos ajuda a entender esse quadro, quando explicita a existência de uma hierarquia sustentada por níveis de legitimidade que o campo científico concede aos seus produtos e produtores. Nesse caso, a Avaliação da Capes legitima os programas e os hierarquiza, seguindo padrões consagrados no campo científico internacional. Os coordenadores, participantes da luta concorrencial que se estabelece no âmbito acadêmico, procuram se adequar a essas regras para conseguir ocupar as melhores posições no campo.

Os coordenadores expressaram o entendimento da inserção internacional "ideal" como uma via de mão dupla, na qual a pós-graduação brasileira tem a aprender e também a ensinar, num diálogo com as pesquisas internacionais, como podemos perceber nas seguintes falas:

Eu entendo a inserção internacional como a interlocução com colegas/ trabalhos de línguas diferentes, mas com ancoragem na nossa realidade. Não adianta fazemos um artigo sobre a nossa realidade, sem interlocução com o que vem sendo discutido internacionalmente, só com bibliografia brasileira, traduzir, e tentar publicar no exterior [...] não será nem aceito. (Coordenador C - Unisinos).

Mas tem uma dimensão disso, que eu acho que é muito importante, que é a questão da internacionalização não apenas como publicação, mas como projetos conjuntos, como intercâmbio institucional etc. [...] Inicialmente, a internacionalização começou com aquela besteira de artigo publicado em revista estrangeira, ou seja, publicar no Paraguai, Uruguai, na Argentina, no México, na Croácia etc. Então, mas, sobretudo que seja em inglês, ninguém vai ler, isso não tem impacto nenhum. Claro, eu acho que essa besteira a gente já superou. (Coordenador D - UFMG).

A despeito das preocupações sobre a maneira como ocorre a internacionalização, os coordenadores consideraram positiva essa experiência, apontando que ela contribui para o desenvolvimento da pesquisa e reconhecendo 
que a Capes têm fomentado esse movimento nos programas, através de editais e de bolsas ${ }^{21}$ :

\begin{abstract}
O professor tem projetos e, a medida que ele consegue sair para "pósdoc" e mestrados seniores, é uma grande janela. Tanto na [Universidade] pública quanto na privada isso é possível. Os estágios sanduíches, tudo isso tem sido estimulado pela Capes também. Ou seja, os estágios sanduíches são feitos tranquilamente, está cada vez mais claro fazer os encaminhamentos. Agora eu vejo que os editais para fazer um contato com a América Latina estão aí. É só a gente fazer a busca, tem muito edital. [A internacionalização] é para ser uma coisa integrada à sua pesquisa. Então, aos poucos, à medida que os pesquisadores se tornam pesquisadores com essa visão, eles vão juntar seus projetos à lógica do debate internacional, porque "eles" querem conversar com a gente. Não é assim que eles só querem que a gente os leia. (Coordenador A - Unisinos).
\end{abstract}

\title{
4.2. \\ Contexto de influência nacional: a Capes, a avaliação e o Sistema Qualis
}

Ao analisar o contexto de influência nacional, constatamos que é notório, e cada vez mais forte, o poder da Capes sobre a pós-graduação brasileira. Sua importância é reconhecida pela comunidade acadêmica e sustentada por um sistema de avaliação que passou por uma mudança tangenciada, entre outros aspectos, por questões presentes no contexto de influência internacional.

Nesse sentido, a Avaliação da Capes, embora seja reconhecida como um dos fatores responsáveis pela qualidade da nossa pós-graduação, também é objeto de críticas por parte da comunidade acadêmica. Para aperfeiçoar os aspectos qualitativos dessa avaliação, a Capes lança mão do Sistema Qualis, que por sua vez, reflete hierarquias presentes no campo científico. É desses temas que tratam as próximas seções.

\footnotetext{
${ }^{21}$ Segundo o Programa Ciência Sem Fronteiras vinculado a Capes, o objetivo do doutorado sanduíche é promover a qualificação de alunos matriculados em cursos de doutorados no país para permitir um "[...] aprofundamento teórico, coleta e/ou tratamento de dados ou desenvolvimento parcial da parte experimental de sua tese a ser defendida no Brasil." Fonte: site Ciência Sem Fronteiras. Disponível em: <https://www.cienciasemfronteiras.gov.br/web/csf/doutoradosanduiche> . Acesso em: 21 fev. 2014.
} 


\subsection{1.}

\section{A influência da Capes no contexto nacional de pós-graduação}

Em 2003, Luiz Inácio Lula da Silva, representante da oposição pelo Partido dos Trabalhadores (PT), foi eleito presidente e iniciou um governo que deu seguimento à política econômica de FHC, buscando aliá-la à retomada do crescimento do país, à redução da pobreza e à diminuição da desigualdade social, por meio do investimento massivo em políticas sociais.

Ao longo do seu governo, Lula reafirmou a política de apoio à CT\&I introduzida no período anterior e a Capes ganhou ainda mais respaldo como órgão responsável pela Política de Pós-Graduação Brasileira. Ainda em seu primeiro ano de mandato, Lula nomeou uma Comissão Mista Capes/CNPq ${ }^{22}$, encarregada de elaborar o documento que serviu de base para o Plano Nacional de Pós-Graduação 2005-2010 23 . O referido plano aponta a responsabilidade da União em relação à pós-graduação e dá a Capes amplos poderes, indicando-a como órgão responsável por coordenar a política desse nível de ensino, exercendo função normalizadora e avaliadora, de modo a garantir um padrão nacional de excelência.

Os entrevistados pela pesquisa mencionaram diferentes órgãos e entidades que participam e influenciam os rumos da Política de Pós-Graduação no país, como o Conselho Nacional de Desenvolvimento Científico e Tecnológico (CNPq), a Sociedade Brasileira para o Progresso da Ciência (SBPC) e o Ministério da Ciência e Tecnologia (MCT). Lembraram também que, na Área da Educação, os coordenadores de cursos de pós-graduação têm voz através do Forpred, e os estudantes, professores e pesquisadores, através da Anped. No entanto, todos foram unânimes em apontar que, no contexto de influência da pósgraduação brasileira, é inegável a força da Capes na condução da política de ensino e pesquisa.

Essa situação foi criticada por muitos dos entrevistados, que indicaram que a Capes tem mais poder em relação à pós-graduação que o próprio Ministério da Educação:

Eu diria que a Capes é a instância de maior poder. Algumas vezes parece haver algum distanciamento entre a Capes e o próprio MEC, sendo a Capes, aparentemente, com poder maior. (Dirigente Forpred).

\footnotetext{
${ }^{22}$ Brasil, Portaria Normativa Interministerial, MCT/MEC nº 270, de 22 de maio de 2003.

${ }^{23}$ Mais detalhes sobre o PNPG 2005-2010 são apresentados no tópico 4.3 deste capítulo.
} 
Mas eu acho que há uma distância muito grande entre o que o Forpred decide e o que é implementado na Capes. Então a Capes tem uma estrutura, o CTC da Capes, que é um órgão que delibera, e aí você tem a ficha de avaliação, que é estabelecida pelo CTC. Então, a distância que existe entre a decisão do CTC e as sugestões que são colocadas no Forpred é muito grande. Eu acho que a gente não influencia tanto. Se a gente influenciasse acho que já teríamos certas coisas mudadas. (Coordenador E - UFMG).

A Capes tem um poder sobre a pós-graduação brasileira que, do meu ponto de vista, é excessivo. Por exemplo, quem deveria por lei reconhecer um programa de pós-graduação ou o não funcionamento do programa, autorizar um programa de pós-graduação, seria o Conselho Nacional de Educação. E quem sabe disso? Você sabia disso? Eu não sabia disso! E a comunidade científica não sabe disso. É claro que foi outorgado a Capes fazer isso na prática. Então a Capes tem um poder exagerado do meu ponto de vista da definição da Política de Pós-Graduação no Brasil. (Dirigente Anped).

Com certeza a Capes é o órgão mais importante. A Capes e, evidentemente, as comissões da Capes. Estamos falando também das comissões [de avaliação]; elas geralmente são convocadas pela Capes, mas elas não são formalmente da Capes, em si [...]. Quem tem a direção realmente é a Capes e suas diversas comissões. (CA-Edu A).

O poder exercido pela Capes na atual Política de Pós-Graduação, que conta com a avaliação como carro-chefe do sistema, permite estabelecer relações também com aspectos da cultura da performatividade. O primeiro deles é o papel do Estado como auditor e avaliador em relação ao serviço educacional oferecido. O Estado brasileiro exerce sua função auditora através da Capes, que reconhece os programas de pós-graduação, estabelece parâmetros e metas a serem seguidos e os avalia periodicamente, determinando sua "posição" no sistema. Nesse sentido, o atual processo de avaliação adotado pela Capes compara e classifica os programas de pós-graduação e suas instituições.

Ball (2005) afirma que a performatividade utiliza o discurso da eficiência e da qualidade para se inserir na cultura das instituições, além de empregar julgamentos e comparações para diferenciar e classificar indivíduos e organizações. O novo modelo de avaliação adotado pela Capes a partir do final dos anos 90 reforçou a função classificatória da avaliação, levando a mudanças que serão vistas mais detalhadamente nas próximas seções. 


\subsection{2.}

\section{A Avaliação da Capes no novo modelo}

Desde o I PNPG, a Capes avalia os cursos de pós-graduação. O primeiro processo iniciou-se em 1976 e tinha como objetivo gerar parâmetros para orientar a distribuição de bolsas de estudo. A ideia era que as bolsas fossem destinadas aos melhores cursos, que as usariam de forma mais responsável e eficaz. A avaliação para a classificação dos cursos era realizada por Comitês de Área, com foco na produção científica dos pesquisadores ligados a cada programa. Desde sua gênese, portanto, a avaliação da pós-graduação tem a produção científica como importante balizador.

Em 1980, a Capes implantou um Sistema de Avaliação dos cursos, através de modelo próprio, baseado na coleta de dados por meio de relatórios encaminhados anualmente pelos programas. A avaliação era realizada por comissões formadas por membros da comunidade acadêmica e relacionava diretamente a alocação de recursos aos resultados da pós-graduação (VERHINE; DANTAS, 2009).

O modelo de avaliação implantado pela Capes utilizava uma escala única de classificação, com cinco níveis, expressos em conceitos de A até E. Cursos consolidados recebiam os conceitos $\mathrm{A}$ ou $\mathrm{B}$, cursos em processo de consolidação recebiam conceito $\mathrm{C}$ e cursos com deficiências recebiam conceitos $\mathrm{D}$ ou E. Esse sistema trouxe contribuições importantes para a pós-graduação e, segundo Balbachevsky (2005), permitiu o estabelecimento de uma conexão entre desempenho e sucesso, pois quanto melhor a avaliação alcançada pelo programa, maiores suas chances e as de seus pesquisadores de obter apoio da Capes, tanto na forma de bolsas de estudo como de recursos para pesquisa e infraestrutura.

Embora parte importante de suas características permaneça até os dias atuais, esse modelo de avaliação apresentava problemas, como a dificuldade de enquadramento adequado dos cursos (em especial os que se encontravam em fase inicial) e o fraco poder discricionário da escala. Eram válidos apenas os diplomas dos cursos com notas A, B ou C e, nesse grupo, só havia uma subdivisão: os cursos consolidados e os cursos em consolidação. Dessa forma, havia dificuldade de distinção de estágios de desenvolvimento de cursos heterogêneos. $O$ problema se agravou com o passar dos anos, pois foi crescendo o número de avaliações 
positivas, tanto em função da dificuldade imposta pela escala como, especialmente, em razão de pressões dentro da própria comunidade científica brasileira.

Para mudar essa situação, estabelecendo uma avaliação mais distintiva e com parâmetros mais objetivos, conforme ocorria internacionalmente, a Capes reformulou seu sistema. Nos anos de 1990, com base nas discussões que se desenvolveram tendo em vista a formulação do IV PNPG, a agência estabeleceu um novo modelo de avaliação, considerado mais rígido (BALBACHEVSKY, 2005). Esse novo modelo, que foi introduzido em 1998 para o biênio 1996/1997, mudou o ciclo avaliativo de bianual para trienal, preservou a autoridade dos comitês (avaliação por pares) e adotou um conjunto de indicadores e de regras mais objetivo.

A partir da reformulação do Sistema de Avaliação, os conceitos básicos que caracterizam o nível de desempenho dos programas reconhecidos pela Capes passaram a ser expressos por notas que podem variar de 3 a 7 . Para a determinação dos conceitos dos programas de pós-graduação, atualmente, são analisados e avaliados os seguintes quesitos: proposta do programa; corpo docente; corpo discente; teses e dissertações; produção intelectual; e inserção social $^{24}$. De acordo com o resultado da análise, como já mencionamos, são conferidas as seguintes notas e conceitos: "5" (Muito Bom), “4” (Bom) e "3" (Regular). A nota "3" é o mínimo que um programa precisa atingir para ser oficialmente reconhecido. Atualmente, os programas com notas " 6 " e "7" (Programas de Excelência) são aqueles enquadrados como conceito " 5 " pela segunda vez na avaliação trienal e que, em uma segunda rodada de avaliação, apresentam desempenhos equivalentes aos dos centros internacionais de excelência e têm nível de desempenho altamente diferenciado em relação aos demais programas (CAPES, 2013b).

Os programas que atingem esse patamar passam a participar do Programa de Excelência Acadêmica (Proex), que tem como objetivo manter o padrão de qualidade dos programas de pós-graduação com nota 6 ou 7, por meio de um financiamento diferenciado. O Proex é restrito a um grupo exclusivo de programas, já que não pode contemplar um número maior do que $7 \%$ (sete por

\footnotetext{
${ }^{24}$ Ver quadro 6 no tópico 4.3.2 deste capítulo.
} 
cento) do total de programas reconhecidos pela Capes. Entretanto, ele corresponde a 15\% (quinze por cento) do orçamento da Capes para bolsas e fomento à pósgraduação no país.

Os programas inseridos no Proex recebem uma dotação orçamentária maior, que pode ser utilizada de acordo com prioridades por eles estabelecidas, desde que respeitada à meta anual mínima de 50\% (cinquenta por cento) para custeio de bolsas de estudo. Além das bolsas, o restante da verba pode ser utilizado em outras das modalidades de apoio concedidas pela Capes: investimento em laboratórios; elaboração de dissertações e teses; passagens; eventos; publicações; entre outros (CAPES, 2006).

Por consistir em uma vantagem financeira que possibilita um maior número de bolsas, além da autonomia que esses recursos proporcionam e do reconhecimento simbólico advindo dessa classificação, os programas de pósgraduação têm grande interesse em ser reconhecidos como Programas de Excelência em suas áreas.

De acordo com Horta e Moraes (2005), o novo modelo introduziu uma importante mudança na Política de Pós-Graduação: o deslocamento da centralidade da docência para a centralidade da pesquisa e da produção científica.

A avaliação trienal dos cursos na Capes é desenvolvida pelos comitês de área, formados por consultores acadêmicos escolhidos dentre profissionais de comprovada competência em pesquisa e ensino de pós-graduação. Embora com uma margem restrita de autonomia, os comitês de área também são responsáveis pelo estabelecimento de critérios e diretrizes para essa avaliação, que são divulgados em documentos dos comitês das respectivas áreas. Entre suas atribuições, compete aos comitês de área a qualificação da produção científica pelo Sistema Qualis em cada área de pesquisa.

\subsection{3.}

\section{O Sistema Qualis}

Em relação à avaliação dos programas, uma das formas encontradas pela Capes para buscar minimizar problemas envolvendo produtividade versus qualidade foi a classificação dos veículos de divulgação científica segundo sua qualidade e abrangência, por meio do Sistema Qualis. Criado em 2001 para 
classificar a produção bibliográfica (principalmente periódicos) dos docentes e discentes dos programas de pós-graduação brasileiros em todas as áreas de conhecimento, o sistema passou a ser um importante parâmetro nas avaliações trienais.

A base de dados Qualis é referência para avaliação da produção científica nacional e reúne apenas os títulos de periódicos utilizados pelos programas de pós-graduação para a divulgação da produção intelectual de seus docentes e alunos. Esse instrumento orienta a comunidade universitária a buscar um padrão de excelência para os cursos stricto sensu (PINTO; CUNHA, 2008).

O Sistema Qualis busca estratificar a qualidade da produção intelectual dos programas de pós-graduação através da classificação de periódicos, livros e capítulos de livros com base em padrões de qualidade da produção intelectual. O objetivo primordial desta avaliação é fornecer informações para a qualificação da produção científica docente e discente dos programas de pós-graduação. Os dados sobre produção científica não são os únicos levados em conta no processo de análise dos programas, embora seja considerado o item com maior peso nas decisões sobre a avaliação (MACEDO; MENANDRO, 1998).

O processo de classificação dos periódicos pelo Sistema Qualis também passou por mudanças. Inicialmente, os periódicos, e parte da produção bibliográfica brasileira, eram classificados em três níveis (A, B ou C) e pelo tipo de circulação (internacional, nacional ou local). Uma mudança na classificação ocorreu em 2008, quando a Capes criou uma nova escala para a produção acadêmica no Brasil, contendo oito estratos: A1, A2, B1, B2, B3, B4, B5 e C. Em cada estrato, a produção bibliográfica possui um número de pontos diferenciado, de forma tal que quanto mais próximo de A, maior a pontuação dos periódicos, sendo A1 a melhor classificação e C a pior. Na Área da Educação, os periódicos classificados como $\mathrm{C}$ não contam ponto. A principal mudança no novo sistema foi a inclusão do Fator de Impacto (FI) na classificação dos periódicos. (ANDRIOLO et al., 2010).

Nas avaliações trienais 2010 e 2013, os resultados da qualificação de periódicos no Sistema Qualis foram ponderados para fins de avaliação conforme o quadro de valores abaixo: 


\begin{tabular}{|c|c|}
\hline Estrato & Peso \\
\hline A1 & 100 \\
\hline A2 & 85 \\
\hline B1 & 70 \\
\hline B2 & 55 \\
\hline B3 & 40 \\
\hline B4 & 25 \\
\hline B5 & 10 \\
\hline C & Sem valor \\
\hline
\end{tabular}

Fonte: Capes, 2010.

No começo da classificação da produção acadêmica brasileira, também os livros (integrais), capítulos de livros e trabalhos completos em anais publicados por pesquisadores e discentes seguiram a mesma lógica dos artigos em periódicos, tendo sido divididos entre os estratos A, B e C e conforme sua circulação fosse internacional, nacional ou local. Com a nova classificação, em 2008, a classificação dos livros ficou definida como: L4, L3, L2, L1 e LNC (sem classificação), sendo L4 o estrato mais elevado e LNC o de produções não pontuadas e sem valor na classificação.

A mudança dos estratos do Qualis ocorreu em razão da baixa discriminação da classificação anterior, uma vez que, nas Avaliações Trienais, a grande maioria das publicações docentes estava classificada nos estratos mais elevados, chegando a $50 \%$ ou $80 \%$ do total de publicações (ANDRIOLO et al., 2010). Assim como ocorrera com a escala de classificação dos programas, o problema da falta de distinção entre diferentes níveis de classificação se repetia na avaliação da produção intelectual. Isto levou a Capes a criar um número maior de estratos com o objetivo de permitir uma maior discriminação na produção acadêmica e também a redução do número de periódicos classificados nos níveis mais altos (A1 e A2).

Os periódicos podem ter distintas classificações em distintas áreas dentro do Sistema Qualis. Assim, um periódico pode ser A1 na Área da Educação e B4 na Área da Saúde Pública, por exemplo. Para algumas áreas foi proposta a equivalência de publicações de estratos mais baixos e também que a somatória de artigos no estrato B (principalmente B1 e B2) possa equivaler a um artigo do estrato A (A1 ou A2). 
Segundo Manzini (2013), o CNPq também começou a utilizar a mesma classificação da Capes nos comitês de áreas para classificar os pesquisadores para pedidos de bolsas, auxílio para desenvolvimento de projetos e participação em eventos científicos. A partir daí, o propósito inicial do Qualis, de subsidiar a avaliação da pós-graduação brasileira, foi extrapolado, e hoje a classificação obtida pelos periódicos e livros tem efeito significativo na comunidade científica. Os resultados da referida avaliação têm servido como ferramenta para auxiliar na concessão de financiamentos; para a inclusão dos títulos em bibliotecas e de indexadores; para orientar pesquisadores e leitores no momento de escolha de periódicos e títulos para submissão de seus trabalhos ou para pesquisar material bibliográfico de relevância, bem como para estimular editores a elevar o padrão de qualidade considerado pelas avaliações a fim de manter os financiamentos.

Em um sentido mais amplo, pode-se afirmar que hoje a avaliação de periódicos se constitui em um elemento fundamental da produção de conhecimento na pós-graduação. É fato que, com este novo sistema, a comunidade científica brasileira precisa perseguir patamares elevados de produção bibliográfica. Docentes que não acompanham tais exigências se arriscam a não obterem financiamento para suas pesquisas ou até mesmo a serem descredenciados pelos programas de pós-graduação.

Assim, em função do aprimoramento do Sistema Qualis na classificação e estratificação dos veículos de divulgação acadêmica, notadamente dos periódicos, o que temos é uma predominância do artigo como o indicador mais valorizado para avaliação do desempenho dos programas. Os periódicos científicos possuem fonte bibliográfica de referência, ou seja, bases indexadoras que, segundo a Capes, possibilitam maior visibilidade e facilitam o acesso à produção científica de suas áreas. Entre as diversas avaliações pelas quais passam as revistas brasileiras (CNPq e Fundações de Amparo a Pesquisa, para financiamento; Scielo e outras bibliotecas, indexadores em geral), a avaliação realizada para alimentar a base Qualis é a que tem gerado grande repercussão na Área da Educação.

O Sistema de Avaliação atual da produção de conhecimento científico no Brasil considera o tipo de veículo de comunicação no formato de artigo como o meio de produção mais valorizado no contexto acadêmico-científico. Nesse sentido, o Qualis passa a ser acionado como uma estratégia de: 
[...] impor uma definição da ciência (isto é, a de limitação do campo dos problemas, dos métodos e das teorias que podem ser considerados científicos) que mais esteja de acordo com seus interesses específicos. (BOURDIEU, 1983a, p.127).

Como o artigo é um produto tradicionalmente mais característico das Áreas de Ciências Exatas e Naturais, uma das críticas mais comuns nas Áreas de Ciências Humanas e Sociais é que este sistema favorece a avaliação das primeiras em detrimento das segundas.

As avaliações de livros ou capítulos de livros são mais frequentes na Área das Ciências Humanas e Sociais e podem ser consideradas um avanço. Em particular, na Área da Educação, o marco inicial da classificação de livros em estratos ocorreu na $111^{\mathrm{a}}$ Reunião do Conselho Técnico-Científico (CTC) da Capes em 2009, quando foi elaborado um roteiro norteador para esta classificação. Segundo o relato da reunião, disponibilizado pelo Fórum Nacional de PróReitores de Pesquisa e Pós-Graduação das IES Brasileiras (Forprop), e o Roteiro para Classificação de Livros - Avaliação dos programas de Pós-Graduação da Capes $\left(111^{\mathrm{a}}\right.$ Reunião do CTC):

Ficou definido no CTC que não teremos mais o QUALIS LIVROS, conforme estava previsto inicialmente. Foi constatada a impossibilidade de se desenvolver um QUALIS LIVROS, tanto pelo tempo requerido como pelas diferenças entre as áreas com relação à valoração dos livros em sua avaliação. Neste sentido, foi definido pelo CTC que teremos um ROTEIRO PARA AVALIAÇÃO (CLASSIFICAÇÃO) DE LIVROS. O documento Roteiro para Avaliação de Livros foi aprovado consensualmente pelo CTC e será o documento norteador para as áreas que utilizam livros em sua avaliação [...]. (FOPROP, 2009, p. 1-2, grifos do autor).

Em várias áreas de conhecimento, os livros constituem uma das modalidades privilegiadas de veiculação da produção artística, tecnológica e científica. Em outras áreas, no entanto, a produção é expressa notadamente sob a forma de artigos em periódicos. Livros constituem referências para a construção de campos de conhecimento, definindo estilos e escolas de pensamento. No entanto, avaliar a produção na forma de livros é um exercício peculiar, uma vez que não existem exemplos no mundo de países que classifiquem livros, o que significa que estamos em face de uma situação original e particular da comunidade acadêmica brasileira. (CAPES, 2009, p. 1).

O Roteiro para Classificação de Livros - Avaliação dos programas de PósGraduação da Capes (111 a Reunião do CTC) deixa claro a inexistência de bases 
bibliométricas e indexadores equivalentes à classificação de periódicos para os livros, acentuando a necessidade de critérios próprios para referenciar a criação de novos instrumentos.

O Documento de Área da Educação 2009 (Triênio 2007-2009) ${ }^{25}$ destaca o incremento da produção científica dos docentes na Área, especialmente na forma de livros (obra integral e coletânea) e indica a necessidade de melhorar essa classificação. Para um livro passar pelo instrumento de classificação ele deve possuir ISBN ou ISSN, um mínimo de 50 páginas e ser derivado de um produto intelectual e fruto de investigação de docentes de pós-graduação. Segundo o documento:

A avaliação levará em consideração, especialmente para o estrato mais elevado, quesitos de relevância da temática, caráter inovador da contribuição e potencial de impacto, tais como definidos pelo CTC. Além desses aspectos, serão considerados aspectos formais - autoria, editoria, financiamento, reedição, prêmios - que valorizam a obra, embora não sejam obrigatórios. Para fins de classificação, as obras serão subdivididas de acordo com sua natureza em: (a) obra integral; e (b) coletânea e dicionários. (CAPES, 2010, p. 5).

Em complemento, o Documento da Área da Educação 2013 informa que houve ampliação do índice de produção bibliográfica de docentes em livros. A publicação de livros tornou-se, ao lado dos periódicos, peça fundamental para a inserção dos programas em nível internacional, sendo este fato destacado no documento. Entretanto, a avaliação de livros constitui um grande desafio, pois:

\begin{abstract}
A caracterização e a análise desta produção tem sido o maior desafio que a área de educação apresenta, principalmente considerando que a expressão da produção acadêmica desta área, prioritariamente, configura-se na forma de livros e não existem ainda experiências nacionais ou internacionais padronizadas para análise e classificação de livros. Na área da Educação avaliar os livros produzidos significa analisar cerca de 4500 dos mesmos em um triênio. (CAPES, 2013b).
\end{abstract}

Existem bases de dados internacionais de livros disponíveis, mas estas não são reconhecidas nem valorizadas como o são as bases indexadas. Por conta dessa lógica, que torna o periódico o objeto de preferência tanto para publicação como para consulta, diversas bibliotecas começam a destinar verbas para assinatura de revistas científicas, restando pouco investimento para a aquisição de livros (MARCHLEWSKI; SILVA; SORIANO, 2011).

\footnotetext{
${ }^{25}$ Documento publicado em 19 de junho de 2010.
} 
$\mathrm{Na}$ realidade brasileira, uma mudança significativa foi a implantação do Scielo Livros, que disponibiliza 446 títulos de livros, entre os quais 278 títulos e 3.997 capítulos de livros com acesso aberto, com 1.980 autores e 15.877.393 downloads $^{26}$.

\subsection{4.}

\section{Críticas na literatura acadêmica em relação à Avaliação da Capes}

A Capes espera que a pós-graduação seja o locus de produção de conhecimento e de formação de pesquisadores e isso pode ser observado na mudança da unidade básica de avaliação da pós-graduação dos cursos para os programas, no destaque dado aos cursos de excelência (compreendida como inserção internacional) e na busca da organicidade entre linhas de pesquisa, projetos, estrutura curricular, publicações, teses e dissertações (HORTA E MORAES, 2005). No entanto, é a ênfase avaliativa sobre a produção bibliográfica qualificada é que indica a expectativa de ampla divulgação dos resultados da capacidade instalada de pesquisa. Estas mudanças estão inseridas no contexto mais amplo das mudanças econômicas no cenário mundial, no qual a produção científica ganha relevância cada vez maior.

O Relatório de Avaliação da Área da Educação 2013 informa que, paralelamente à ampliação da oferta, tem-se buscado melhorar a qualidade da pósgraduação brasileira. A avaliação dos programas da Área da Educação visa fornecer informações sobre o grau de sucesso das políticas adotadas ao longo dos anos. Sobre a questão da qualidade, Vilaça e Palma (2013) afirmam ser este um tema que expressa uma preocupação antiga e perene na academia. Os autores afirmam, de forma assumidamente provocativa, que não sabemos definir o que é uma pesquisa de qualidade e que, mesmo assim, emitimos discursos sobre qualidade que tem um poder normativo, distintivo e hierarquizador.

Verhine e Freitas (2012) também apontam a dificuldade de determinar a qualidade da pós-graduação. Os autores afirmam que, entendendo como válida a vinculação da qualidade da pós-graduação à qualidade da pesquisa nela produzida, o desafio passa a ser encontrar uma forma de avaliar a qualidade da pesquisa realizada nos cursos. Segundo eles, a dificuldade de estabelecer indicadores que

\footnotetext{
${ }^{26}$ Dados levantados em 12 de fevereiro de 2014, no Portal Scielo Livros.
} 
possibilitem aferir a qualidade é um problema enfrentado no mundo todo, tendo sido comum, para esse fim, a utilização de critérios secundários como os índices de impacto dos periódicos, como ocorre em nosso sistema, através do Qualis.

No PNPG 2011-2020, a Capes aponta o seu modelo de avaliação como uma experiência bem sucedida, assentada em três eixos principais:

\begin{abstract}
[...] 1 - ela é feita por pares, oriundos das diferentes áreas do conhecimento e reconhecidos por sua reputação intelectual; 2 - ela tem uma natureza meritocrática, levando à classificação dos e nos campos disciplinares; 3 - ela associa reconhecimento e fomento, definindo políticas e estabelecendo critérios para o financiamento de programas. (BRASIL, 2010, p. 124)
\end{abstract}

No entanto, a própria Capes também aponta distorções e a necessidade de ajustes no modelo, e chama atenção para alguns pontos, como: (a) o fato de sempre ter havido uma hegemonia das Áreas de Ciências Exatas e Naturais, que acaba influenciando os critérios e procedimentos das demais áreas; (b) o predomínio da quantidade sobre a qualidade, ocorrido em função do "taylorismo intelectual" ${ }^{27}$; (c) a adoção de parâmetros das áreas básicas e acadêmicas para avaliação de áreas profissionais e aplicadas; e ainda (d) o fato de a periodicidade das avaliações ser curta, o que faria com que os programas mal tenham tempo de esperar os efeitos de eventuais mudanças implementadas (BRASIL, 2010).

Diferentes estudiosos também assinalam questões a serem aperfeiçoadas no sistema. Kuenzer e Moraes (2005) entendem como positiva a indução realizada pelo Estado brasileiro quando postulou a centralidade da pesquisa na pósgraduação e seu caráter de cientificidade. Entretanto, observam que deste modelo decorreram principalmente dois aspectos negativos: a "exacerbação quantitativista" e o "surto produtivista", que ainda precisam ser mais bem equacionados. Para as autoras, as exigências relativas à produção acadêmica acabaram por fazer com que a quantidade se instituísse como meta. Também a ação reguladora da Capes sobre o prazo máximo de duração dos cursos, com a necessária redução dos tempos médios de titulação, se sobrepôs, em grande medida, à qualidade da formação, principalmente no mestrado. Embora tenha havido avanços proporcionados pelo melhor dimensionamento dos tempos de

\footnotetext{
27، Atualmente, intensifica-se o que Tragtenberg denominou de 'taylorismo intelectual', qual seja: a) Submissão do trabalho intelectual às leis de reprodução do capital; b) Submissão à hierarquização social e do trabalho; c) Aquisição do hábito compulsivo de consumir títulos; d) Subordinação do individual e específico ao abstrato e genérico da 'razão burocrática'; e) Divisão do conhecimento em compartimentos estanques." (SILVA, 2005).
} 
titulação, efeitos negativos foram percebidos, notadamente, na fragilidade de parte das dissertações concluídas após a mudança.

Trein e Rodrigues (2011) também abordam o "produtivismo" na academia, mostrando que, no modo de produção capitalista, há uma conversão de objetos e atividades úteis ao homem, em mercadoria, o que afeta o próprio conhecimento científico que sofre um empuxo à mercantilização. Segunda os autores, para aumentar a produtividade, cada membro da equipe assume uma parcela preestabelecida do trabalho e, assim, a produção do conhecimento científico ultrapassa a forma de elaboração artesanal, atinge uma forma manufatureira e caminha para uma forma quase industrial.

Trien e Rodrigues (2011) sustentam que é preciso resgatar os valores sociais da ciência produzida na pós-graduação. Dessa necessidade, decorrem duas questões: "Como medir, de maneira mais adequada e menos perversa a produtividade do pesquisador e a qualidade da pesquisa científica? Por que medir?" (Idem, p.789-790). Sem ter resposta para a primeira pergunta, os autores respondem à segunda, alertando que: como “[...] na sociedade capitalista não há lugar, poder, dinheiro, enfim, mercadoria para todos $[\ldots]$ mede-se para simultaneamente justificar e manter alguns poucos gozando a mercadoria (e, em particular, o conhecimento-mercadoria)" (Ibid.).

De fato, a Capes não esconde que há um limite para programas no grupo que recebe mais recursos, isto é, para o grupo dos programas de excelência. Atualmente a portaria do Proex estabelece em seu artigo $1^{\circ} \S 3^{\circ}$ que: "O apoio da Capes ao Proex não poderá contemplar um número maior do que $7 \%$ (sete por cento) do total de programas reconhecidos [...]" (CAPES, 2006, p. 2). Assim, quanto mais programas conseguem chegar ao nível de produtividade do grupo de excelência, mais a Capes e também as próprias áreas de conhecimento "apertam" os critérios, conforme pode ser constatado no Relatório de Área da Educação da Avaliação Trienal 2013:

Comparou-se o agregado das médias ponderadas da produção dos veículos A e L4 por docente no triênio de todos os programas 5 há dois triênios com MB em todos os quesitos. Tendo em vista os resultados obtidos e os valores praticados no último treino, decidiu-se por um ponto de corte de 200 pontos. [...] Ressalte-se que no triênio 2007-2009 o valor utilizado como ponto de corte foi 130, sendo 200 pontos a média ponderada mínima para os programas 7. (CAPES, 2013b, p. 39-40). 
Esse tipo de situação relaciona-se à cultura da performatividade, na qual o desempenho dos sujeitos e das organizações, ou seja, dos programas, serve como medida de produtividade e rendimento, ou como mostra de "qualidade" estabelecida por meio de um julgamento ou avaliação que ocorre em determinados momentos de "inspeção". Nesse contexto, quem controla esse âmbito tem papel crucial, pois o julgamento acaba determinando o valor de um indivíduo ou organização (BALL, 2002). A definição desse valor, no entanto, tem características arbitrárias, como podemos ver no exemplo do ponto de corte para programas de excelência. O que era suficiente para ser considerado "de excelência" na avaliação trienal de 2010 (130 pontos), deixou de ser na avaliação de 2013 em função de vários programas terem atingido esse patamar. Nesse sentido, concordamos com a afirmação de Ball:

\begin{abstract}
Trabalhamos e agimos numa frustrante sucessão de números, indicadores de desempenho, comparações e competições — de tal maneira que a satisfação da estabilidade é cada vez mais ilusória, os fins são contraditórios, as motivações indistintas e o valor próprio incerto. Dúvidas constantes acerca de que tipo de julgamento/avaliação pode estar em jogo num dado momento, em qualquer momento, significam que toda e qualquer comparação e exigência a desempenhar têm de ser cuidadas com interesse e eficiência. (2002, p. 10).
\end{abstract}

As críticas ao produtivismo não são consensuais na Área da Educação. Macedo e Souza (2010) constatam, através de dados relativos à avaliação trienal 2004-2006, que: (1) há grande variação de médias de produção docente em programas com o mesmo conceito; e que (2) as médias de produção não são muito $\operatorname{altas}^{28}$. Isso leva as autoras a argumentar que não só a produção bibliográfica está sendo considerada na Avaliação da Capes como que também não há "excesso de produção" (produtivismo). Nessa perspectiva, a crítica pode estar relacionada à ideia de que haveria uma relação não sustentada entre quantidade e qualidade, no sentido de que quanto mais quantidade, menor qualidade. As autoras contestam a ideia de que, quando o volume era menor, a produção era consequentemente melhor; alegando que a produção em educação hoje é mais consistente do que o que se produzia nos anos de 1970 e 1980 e que os periódicos atuais, além de mais numerosos, têm mais qualidade. Também para Horta (2006), a oposição entre

\footnotetext{
${ }^{28}$ Nos programas nota 6 , a média anual é de dois produtos (equivalente a capítulo de livro A) por docente. E nos programas 3 a 5, essa média varia de 1 a 1,6 produto (equivalente a capítulo de livro A).
} 
quantidade e qualidade não pode ser colocada de forma absoluta, no sentido de que também não há qualidade sem quantidade.

Atores importantes neste debate são os coordenadores dos cursos de pósgraduação. Horta (2006) sistematiza a visão dos coordenadores a respeito do modelo atual de avaliação, com base nas críticas e sugestões enviadas à Capes na ocasião do preenchimento do Coleta Capes ${ }^{29}$ 2004. As críticas foram agrupadas em cinco blocos: caráter homogeneizador do modelo; ênfase em indicadores quantitativos e produção bibliográfica; ausência da valorização da dimensão social; inserção internacional; e consequências da avaliação.

O interesse deste estudo é significativo pelo fato de dialogar diretamente com os coordenadores de programas, atores destacados em nossa pesquisa, e por mostrar as principais dificuldades deles em relação ao modelo atual de avaliação.

Em primeiro lugar, os coordenadores enfatizam a necessidade de se levar em conta a especificidade de cada Grande Área, de cada Área, de cada programa, das diferentes regiões do país. Estudos mais recentes e documentos atuais da Capes, como o PNPG em vigor, também apontam a necessidade de enfrentar essa questão. A segunda crítica do grupo, já abordada pela academia, é relativa ao quantitativismo e ao produtivismo. Os coordenadores sugerem que aspectos qualitativos e atividades de formação recebam mais atenção da avaliação. A terceira crítica refere-se à ausência de valorização da dimensão social dos programas. Segundo os coordenadores, deveria haver maior valorização da inserção local e regional dos programas e do significado que tal inserção assume na transformação da realidade, bem como no impacto que causa na sociedade.

Entretanto, este não é um tema consensual. Em levantamento feito pela Capes em 2004, membros da comunidade acadêmica demonstraram receio de se abrir espaço para a politização inadequada da pesquisa ou de se transformar a prestação de serviço em um indicador de qualidade (SPAGNOLO; SOUZA, 2004).

A inserção internacional é o quarto ponto abordado pelos coordenadores. Alguns deles, tipicamente da Área da Física e da Ciência e Tecnologia de

\footnotetext{
${ }^{29}$ O Aplicativo Coleta de Dados Capes é um sistema informatizado desenvolvido com o objetivo de coletar informações dos cursos de mestrado, doutorado e mestrado profissional integrantes do Sistema Nacional de Pós-Graduação. Fonte: site da Capes. Disponível em: <http://www.capes.gov.br/avaliacao/coleta-de-dados〉. Acesso em: 31 jan. 2014.
} 
Alimentos defendem sua valorização, outros, como os das Ciências Agrárias e da Economia, criticam o peso dado à internacionalização da produção. Para Horta (2006), o problema é que a incapacidade de se aferir o "padrão internacional" faz com que a concepção dominante no Conselho Técnico Científico (CTC) da Capes, seja a de que esse padrão se mede pelos percentuais de publicações internacionais, o que, em algumas áreas, é mais difícil.

Por fim, chegamos a um ponto criticado pelos coordenadores e que está diretamente relacionado com o tema da nossa pesquisa: as consequências da avaliação. Pelas críticas dos coordenadores, é possível perceber que a avaliação interfere profundamente no cotidiano dos programas, que mudam seus critérios de seleção de alunos e credenciamento e descredenciamento de professores, entre outros, para atender os critérios de avaliação da Capes. Será interessante observar como isso se dá nos programas pesquisados nesse estudo e quais as estratégias encontradas pelos coordenadores para a superação de eventuais dificuldades.

Horta (Ibid.) conclui o artigo argumentando que, pela quantidade e pelo teor das manifestações dos coordenadores em relação aos critérios de avaliação, os mesmos sofrem na pele e enfrentam, no cotidiano dos programas, as consequências dessa avaliação, e convida a Capes e as Comissões de Avaliação a se manifestarem também.

\section{3.}

Contexto da produção de texto: PNPGs recentes e os Documentos de Área da Educação

Muitos são os textos relacionados à Política de Pós-graduação Brasileira, desde textos legais (leis, portarias, pareceres), os Planos Nacionais de PósGraduação, os documentos emitidos pela Capes e outros órgãos de fomento da pesquisa e da pós-graduação, além de documentos publicados pelos próprios programas.

Em nossa pesquisa, optamos por apresentar a análise de dois textos que estão relacionados com a Política de Pós-Graduação atual: os Planos Nacionais de Pós-Graduação mais recentes (PNPG 2005-2010 e PNPG 2010-2020), bem como os documentos de Área da Educação. Na análise, procuramos verificar se houve 
busca de consensos na construção dos mesmos e como a Área da Educação e os coordenadores dos programas investigados se posicionam em relação a eles.

\subsection{1.}

\section{Os Planos Nacionais de Pós-Graduação mais recentes: PNPG 2005/2010 e PNPG 2010/2020}

Em 2005, a Capes retoma a publicação dos Planos Nacionais de PósGraduação, mudando a nomenclatura adotada até então. Como o IV PNPG não foi oficialmente lançado e houve um grande período sem um plano oficial, o órgão optou, ao invés de continuar a utilizar a nomenclatura alfanumérica adotada até então (I, II, III, IV PNPG), por associar o nome do plano ao seu período de vigência, nomeando os planos seguintes como PNPG 2005-2010 e PNPG 20102020.

A retomada da publicação dos PNPGs pode ser interpretada, em parte, como uma estratégia de reafirmação simbólica da política estabelecida pela Capes. Segundo Ball (2002), no contexto de performatividade, é cada vez mais exigido que as instituições do setor público construam uma variedade de relatórios textuais como planos de desenvolvimento e documentos estratégicos, entre outros, que simbolizam e representam o consenso institucional.

Embora o PNPG 2010-2020 seja mais alentado e tenha um período de vigência maior que o PNPG 2005-2010, os dois planos são congruentes entre si e reafirmam a Capes como órgão responsável pela coordenação, articulação e avaliação da pós-graduação, extrapolando, também, seu âmbito de atuação de modo a abranger parte da Educação Básica e da formação de professores. Aqui, e como veremos mais detalhadamente ao longo do tópico, os documentos revelam a força da Capes, constatada e apontada no contexto de influência.

O PNPG 2005-2010, lançado no governo Lula, reafirma o papel do Estado como principal financiador do sistema, sendo a Capes responsável pela condução da pós-graduação no país. O texto afirma a necessidade de fortalecer as bases científicas brasileiras, formar docentes para todos os níveis de ensino e quadros para os mercados não acadêmicos. Diante disso, a sugestão foi a diversificação do sistema através da proposição de novos modelos, como o mestrado profissional e as experiências de educação a distância e de cooperação institucional. 
Talvez um dos exemplos mais eloquentes da força da Capes como órgão regulador do Estado se revele quando, pela primeira vez, um PNPG passa a atribuir à pós-graduação responsabilidades diretas sobre a Educação Básica e a formação de seus docentes. Trata-se de uma mudança importante em termos de objetivos do sistema de pós-graduação e também das atribuições da Capes, que passa a coordenar ações direcionadas a os outros níveis de ensino.

Na análise do contexto da pós-graduação, os dados do PNPG 2005-2010 mostram que o sistema cresceu em número de cursos e de alunos matriculados e titulados em todas as regiões do país e em todas as áreas de conhecimento. Todavia, os desequilíbrios regionais persistem e nosso sistema ainda é pequeno quando comparado ao de países desenvolvidos e de países concorrentes em áreas da política industrial brasileira ${ }^{30}$. Em face destas questões, o PNPG 2005-2010 definiu como objetivo principal o crescimento equânime do sistema nacional de pós-graduação, visando o desenvolvimento científico, tecnológico, econômico e social do país. Para alcançá-lo, estabeleceu seis diretrizes principais: (a) estabilidade e indução, (b) estratégias para melhoria do sistema, (c) financiamento e sustentabilidade, (c) novos modelos, (d) políticas de cooperação internacional e de formação de recursos humanos no exterior e, (e) avaliação e qualidade.

A estabilidade refere-se à manutenção do ritmo de crescimento do sistema e à indução, por meio de financiamento a ações que visem reduzir as diferenças regionais, intrarregionais e entre estados. Algumas estratégias foram determinadas, tais como a elaboração de programas específicos pelas agências de fomento objetivando solucionar diferentes tipos de assimetrias; diversificação do sistema, com novos modelos para a pós-graduação (novos tipos de mestrado, cooperação interinstitucional, expansão de bolsas para estágio, educação a distancia); e ainda políticas de cooperação internacional e de formação de recursos humanos no exterior.

Na sequência, o PNPG 2005-2010 traçou cenários de crescimento para a pós-graduação, baseados nas séries históricas existentes e na combinação de três cenários possíveis. A partir deles, apresenta as metas e o orçamento necessário

\footnotetext{
${ }^{30}$ Países apontados como competidores em áreas da política industrial: Cingapura, Coréia do Sul, China, Espanha, Índia e Taiwan.
} 
para a realização do PNPG no período de 2005-2010. O texto aponta a necessidade de uma ação indutiva da pós-graduação nas regiões Norte, Nordeste e Centro-oeste, com o aumento do investimento e do número de professores e sinaliza que o mesmo esforço deve ser feito em relação à superação das assimetrias intrarregionais. $O$ texto destaca o papel das agências de fomento, das Secretarias Estaduais de Ciência e Tecnologia e de fundações de apoio, especialmente a Financiadora de Estudos e Projetos (Finep), por ser ela gestora dos fundos setoriais, na superação das assimetrias. Também menciona as empresas estatais como uma importante fonte de apoio no financiamento da pósgraduação nacional.

O Plano também relaciona diretamente a qualidade e a excelência dos programas aos seus resultados, indicando a necessidade de preservação e fortalecimento do sistema de avaliações periódicas que considere o impacto de produção científica e tecnológica dos programas para os setores econômico, industrial e social. Por fim, aponta que a avaliação deve ser baseada na qualidade e na excelência dos resultados, dando ênfase à produtividade dos docentes $\mathrm{e}$ discentes. Cabe destacar que, nesse item, há sugestão de diversificação do sistema de avaliação, com a introdução de processos de avaliação qualitativa dos produtos dos programas, como livros, patentes e tecnologias.

Aqui, mais uma vez, o contexto da produção de texto guarda sintonia com as influências internacionais que apontam a avaliação como elemento importante das políticas educacionais. Nesse desenho, a avaliação torna-se um elemento norteador do trabalho de gestão dos programas, diante das exigências cada vez mais específicas em relação à produção científica e da atenção cada vez maior a ser prestada aos parâmetros de avaliação estabelecidos pela Capes.

Ainda no governo Lula (2010), a Capes aprovou o atual Plano Nacional de Pós-Graduação (PNPG 2010-2020), divulgado no primeiro ano de atuação de sua sucessora, Dilma Rousseff, em julho de 2011. O contexto político e econômico brasileiro do período era favorável à pós-graduação, pois no começo da segunda década do século XXI, o Brasil aparece como potência emergente, ao lado de China, Rússia, Índia e África do Sul. O documento mostra o clima de otimismo do governo, que trabalha com a perspectiva de o Brasil vir a tornar-se a quinta economia mundial durante o período de sua vigência. 
O PNPG 2010-2020 é mais alentado e tem um período de vigência maior que o anterior, o que denota um esforço da Capes em estabelecer objetivos de mais longo prazo para a pós-graduação, relacionando-os aos grandes temas nacionais, ancorando-os em projeções para a próxima década e articulando esse nível de ensino à Educação Básica e à graduação.

$\mathrm{Na}$ análise dos dados relativos à situação atual da pós-graduação, é reforçada a ideia de que a pós-graduação está diretamente ligada aos níveis anteriores de ensino, dos quais provêm seus alunos. O texto constata que a oferta de candidatos à pós-graduação no país ainda é baixa e que a formação pósgraduada é longa e tardia. Diante disso, o Plano recomenda que a Educação Básica seja objeto de estudos e de propostas pelo Sistema Nacional de PósGraduação, e que a formação especializada seja revertida para patamares etários mais baixos, ou seja, na formação de mestres e doutores mais jovens.

Em relação à evolução quantitativa da pós-graduação, o Plano observa que o sistema cresceu no que diz respeito ao número de cursos recomendados pela Capes $^{31}$ e teve notável incremento no número de titulados ${ }^{32}$. Argumenta, no entanto, que para atingir níveis compatíveis com as nações avançadas, o sistema ainda precisa ser fortemente expandido. Além disso, faz projeções de crescimento da pós-graduação brasileira, estabelecendo duas grandes metas para 2020, que incluem o aumento do número de doutores e metas anuais de titulação de doutores, mestres profissionais e mestres acadêmicos ${ }^{33}$.

O Plano 2010-2020 elegeu a diversidade e a busca pelo contínuo aperfeiçoamento como princípios para nortear a avaliação na próxima década. Também abordou a importância da inter(multi)disciplinaridade na pós-graduação. A Capes considera que existe um grande potencial científico na pós-graduação e indica que o carro-chefe do sistema devem ser as experiências interdisciplinares dos programas, áreas de concentração e linhas de pesquisa.

Um problema recorrente desde o primeiro PNPG são as assimetrias regionais, que no Plano vigente foram abordadas utilizando-se como parâmetro a

\footnotetext{
${ }^{31}$ De 1976 a 2009, o número dos cursos de mestrado cresceu 370,3 \% e de doutorado 685,6\%. Em 1976, não havia cursos de mestrado profissional. De 2004 a 2009, o número de cursos de mestrado cresceu $35,9 \%$, de doutorado $34,4 \%$ e de mestrado profissional $104,2 \%$.

${ }^{32} \mathrm{O}$ número de alunos titulados no mestrado acadêmico e doutorado eram, respectivamente, de 3.665 e 864 (em 1987) e passou para 35.698 e 11.368 (em 2009). Em relação ao mestrado profissional, havia 56 titulados em 1999 e 3.102 em 2009.

${ }^{33} \mathrm{~A}$ meta é ter uma titulação anual de 19 mil doutores, 57 mil mestres e 6 mil mestres profissionais.
} 
distribuição geográfica por mesorregião, para agregar precisão ao diagnóstico. Embora o documento reconheça ter havido alguns avanços, ainda assim aponta ser necessário adotar diretrizes específicas para o equacionamento do problema, como a indução de programas em áreas de interesse nacional; o estímulo a centros de excelência e redes de pesquisa para formação regional; a atração e fixação de pessoal qualificado nas regiões necessitadas e a adoção de mecanismos para corrigir as distorções existentes.

Em relação ao papel da pós-graduação na formação de recursos humanos, o texto destaca a necessidade de formar pessoal altamente qualificado para as empresas e para os programas nacionais. Segundo o Plano, desde o início da pósgraduação até a atualidade, tem havido insuficiente articulação entre as empresas e as instituições de Ciência e Tecnologia no Brasil. Como caminhos necessários para a reversão desse quadro, são apontados a melhoria da qualidade de ensino em todos os níveis; a criação de novas formas de inserção no mercado de trabalho; o estímulo à inserção de mestres e doutores nas empresas; a promoção de uma agenda acadêmica para apoiar os processos de inovação no parque industrial do país; e o apoio a iniciativas na pós-graduação que contemplem uma melhor integração entre Universidades, governo e empresas.

Como vimos no início do capítulo, a preocupação com a produção de C\&T também é um tema presente no contexto de influência internacional. Assim, ao tratar do tema da internacionalização da pós-graduação, é feito um diagnóstico positivo do aumento da presença internacional da Ciência e Tecnologia brasileiras. Explicitando a necessidade de se buscar a excelência evitando-se a endogenia, o Plano sugere o envio de mais doutorandos ao exterior, o estímulo à atração de alunos e pesquisadores visitantes estrangeiros e o aumento do número de publicações com instituições estrangeiras.

Em complemento, no tópico sobre financiamento da pós-graduação, o PNPG 2010-2020 recomenda um aumento do percentual do PIB e do percentual privado investido em Ciência, Tecnologia e Inovação (CT\&I); a adoção de agenda estratégica nacional para proporcionar robustez aos investimentos; uma maior flexibilização no uso dos recursos e a diminuição dos entraves burocráticos entre o setor acadêmico e empresarial.

O atual PNPG (2010-2020) estabelece em detalhe os principais desafios e temas a serem enfrentados pela pós-graduação brasileira, por meio de ações 
induzidas pelo governo federal. O documento informa que as ações induzidas foram definidas pelo governo e pela comunidade, e que diferentes segmentos da comunidade acadêmica e da sociedade foram convidados a enviar sugestões. No entanto, as entrevistas realizadas ao longo dessa pesquisa apontam que, no processo de elaboração do Plano, faltou a participação da comunidade científica e dos seus representantes.

O dirigente da Anped entrevistado pela pesquisa alerta que o atual PNPG foi realizado por intelectuais escolhidos pela Capes, não tendo sido consultada a Associação, que só teve acesso ao documento pela imprensa, após o mesmo ter ficado pronto.

O PNPG é outro ponto de tensão com a Capes, ele foi feito por uma comissão de notáveis. Isso é algo que a gente leva muito ao Ministro [da Educação]. Digo "olha, um governo que se pretende democrático, popular, não pode fazer um Plano Nacional de Pós-Graduação sem consultar a sociedade civil organizada.” É um absurdo que eles não tenham feito nenhuma audiência pública com a presença da sociedade cientifica. Isso é o mínimo! Eles poderiam até criar uma comissão de notáveis, mas essa comissão precisaria ouvir a sociedade científica. Isso não aconteceu. Um documento feito nos gabinetes da Capes, nos escritórios da Capes. Nós tomamos contato com o documento na mídia, depois de pronto. (Dirigente Anped).

A fala do dirigente da Anped foi confirmada por outros depoimentos, como o de um coordenador de programa e até de um Coordenador de Área, que afirmam ter tido pouco contato com os Planos durante sua elaboração e que a Área de Educação ficou excluída do processo de construção do PNPG.

Por outro lado, eles, não a Capes, o mesmo [grupo] que fez o Plano Nacional de Educação, não tem ideia do que é o processo, do que é Educação. Para eles Educação é Ensino. É complicado! Então o planejamento quem faz é o sociólogo; são pessoas de outras áreas, economistas, não é o educador. Eles não exigem a questão da Educação, esse é o problema. Do que trata essa Área de Educação? Então, no nível nacional, a tal da política sobre a Educação, ainda precisaria ser demonstrada. (CA-Edu A).

[...] o Plano Nacional de Pós-graduação que está em vigor, embora fale muito da Área da Educação, foi elaborado a despeito da Área da Educação. Foi feito por um coordenador, por um colega coordenador da UFMG com participação de vários outros [...] Quer dizer, a despeito do plano falar muito de Educação, sobretudo Educação Básica, foi feito sem a nossa participação. (Coordenador D - UFMG).

Ball considera os documentos das políticas como fruto de disputas de diferentes grupos de interesse (MAINARDES, 2006). O quadro apresentado mostra que há um desequilíbrio de forças quando olhamos a construção do 
documento da perspectiva da Área da Educação. Os coordenadores dos cursos de pós-graduação foram excluídos do processo, assim como o próprio representante da Área da Educação na Capes.

Nessas circunstâncias, é necessário questionar que interesses representam as definições e os objetivos apresentados nos PNPGs. Cabe indagar se o processo de elaboração do PNPG permitiu discussões, interlocuções e, em especial, a tomada de decisão na definição das prioridades pela comunidade acadêmica e pela sociedade. A academia se vê contemplada nas diretrizes estabelecidas?

O representante da Anped apresenta sua visão sobre esse jogo de forças:

A Capes está hoje na mão de um grupo de cientistas de renome, que são tecnocratas. São burocratas da Capes e querem definir a política de pós-graduação no país por meio de uma concepção de ciência que a gente já pensava superada no país, isso é coisa positivista. Não é porque todas as ciências hoje sejam positivistas, mas eles são. É uma concepção deles, são positivistas. E curioso que hoje no Brasil, o presidente da Capes seja um biólogo e o presidente do CNPq também. Achei isso bastante curioso. E que o modelo generalizado para avaliar a pós-graduação brasileira em todas as suas áreas seja o da Biologia. O poder que a Associação Brasileira de Ciência tem hoje na Capes é impressionante! E mais impressionante ainda é que isso tenha se desenvolvido dentro de um governo democrático-popular. Para mim, o pano de fundo disso é uma hipervalorização da ciência pelos setores populares que apoiam esse governo. Talvez seja por isso que se tem tanto medo de "mexer" na Capes. (Dirigente Anped).

Por esses motivos, o PNPG acaba se tornando um documento distante dos atores que põem em prática a política, especialmente na Área da Educação. Um envolvimento maior da academia na definição dos objetivos dos planos certamente ajudaria a atenuar o desagrado com que muitos pesquisadores lidam com as injunções da Capes e das agências de fomento, detentoras dos recursos que os subsidiam.

De forma geral, os coordenadores disseram que não são os PNPGs, mas sim, os Documentos de Área da Educação e a Ficha de Avaliação dos Programas elaborados pela Capes os textos que acabam por interferir mais diretamente em suas atividades de coordenação dos programas.

O Plano Nacional, tanto de Pesquisa quanto de Pós-Graduação, quem é que abriu, leu e fez um comentário? Acho que são poucas pessoas que de fato se empenham nisso [...] eu descobri esse [documento] numa tese! (Coordenador C - UFMG).

O Documento de Área, sim [influencia]. O Plano Nacional de PósGraduação, muito menos, inclusive porque ele não acaba impactando. Eu conhecia, acompanhava a discussão, mas ele acaba impactando pouco o cotidiano do Programa, ele é muito genérico para isso. Mas é claro também que era mobilizado para discutir coisas. Mas com 
certeza, os documentos muito visados, eram tanto o Documento de Área como a Ficha de Avaliação do Programa. (Coordenador D UFMG).

[...] o que nos orienta mais é estar com o Documento de Área, que inclusive nós temos a possibilidade de uma interferência maior, por conta da representação de Área, da comissão de avaliação. Talvez o Documento de Área seja o documento mais importante para gente, porque ali estão as vias gerais para o funcionamento do Programa. (Coordenador A - Uerj).

Não podemos esquecer, contudo, que os Documentos da Área da Educação são alinhados com as orientações gerais estabelecidas nos PNPGs. No próximo tópico, veremos como a Área da Educação foi se construindo dentro da nova política de pós-graduação e como isso se refletiu nos Documentos de Área.

\subsection{2.}

\section{A Área da Educação, a Grande Área de Ciências Humanas e os Documentos de Área}

A cada avaliação trienal, as áreas apresentam um documento que orienta os programas em relação à avaliação, o chamado "Documento de Área". Ele contém a "Ficha de Avaliação dos Programas"34, na qual são sintetizados os critérios de avaliação e seus respectivos pesos. Ao longo dos anos, o Documento de Área vem ganhando mais densidade, com o aumento do número de tópicos abordados e um maior grau de detalhamento ${ }^{35}$. Além dele, as áreas divulgam outros documentos, como o Relatório de Área, que contém detalhes sobre o processo de avaliação; os Cadernos de Indicadores, que contém dados sobre a produção dos programas; bem como ofícios e comunicados. Esse conjunto de

\footnotetext{
${ }^{34}$ A Ficha de Avaliação do Programa é o instrumento utilizado para o registro das avaliações de cada um dos programas de pós-graduação após a análise de mérito realizada pelas Comissões de Área de Avaliação. Há uma Ficha para os programas acadêmicos e outra para os mestrados profissionais. Ambas estruturam-se em quesitos e itens, e destinam-se a: garantir uma base de uniformidade e de padronização do processo de avaliação, bem como a ampliar o nível de integração entre as Áreas no âmbito de sua respectiva Grande Área e no contexto de todas as demais. Fonte: Capes. Disponível em:

< http://www.capes.gov.br/avaliacao/sistema-de-ficha-de-avaliação>. Acesso em: 4 fev. 2014.

35 Atualmente o Documento de Área da Educação é composto pelos seguintes itens: I Considerações gerais sobre o estágio atual da Área, II - Requisitos e orientações para propostas de cursos novos; III - Considerações gerais sobre a avaliação trienal 2013; IV - Considerações sobre o Qualis Periódicos/ roteiro para classificação de livros/ eventos/ produtos técnicos e os critérios para a estratificação e uso dos mesmos na avaliação; V - Ficha de Avaliação para o Triênio; VI Considerações e definições sobre internacionalização/ inserção internacional.
} 
documentos, em especial a Ficha de Avaliação, pautam as ações dos coordenadores nos programas, como foi apontado nos depoimentos registrados na seção anterior.

Vimos que, para Ball (2002), na cultura da performatividade, as instituições são levadas a produzir documentos que simbolizam o consenso institucional. A construção desses documentos, no entanto, pode desencadear um processo que resulte em acordos mais consensuais.

Tais textos simbolizam e representam o consenso corporativo da instituição e, de facto, estes exercícios de extrapolação institucional também podem resultar como meio de criar consenso - o focar de actividades em volta de um conjunto de prioridades "acordadas" (Ball, 1997). Estas proporcionam uma pedra de toque de esforço partilhado que desloca ou agrupa diferenças, desentendimentos e valoriza divergências. (ibid., p.17-18).

$\mathrm{Na}$ Área da Educação, a construção dos documentos que determinam os principais critérios de avaliação e seus respectivos pesos ocorreu em meio a discussões e embates entre os agentes que participam do campo e os que representam a Capes.

Com a implantação do novo modelo de Avaliação da Capes, a Área da Educação sofreu forte impacto. Como resultado da avaliação do primeiro biênio (1996-1997), houve o descredenciamento de vários cursos de mestrado. Na 21 a Reunião Anual da Anped, em 1998, foi elaborado pelos participantes um documento discutindo o modelo de avaliação e propondo alternativas. O processo culminou com o pedido de demissão da então representante de Área, Mirian Jorge Warde.

Horta e Moraes (2005) mostram que, no período subsequente (Triênio 2001), embora tivessem sido mantidas as condições gerais da avaliação, algumas alterações foram introduzidas pela Capes. Entre elas, talvez a mais polêmica tenha sido o novo papel assumido pelo Conselho Técnico Científico (CTC) da Capes. Com efeito, nesse momento, o CTC deixou de ser o órgão encarregado da homologação dos resultados para passar a assumir um papel de rigorosa apreciação e questionamento das análises e avaliações realizadas pelas comissões 
de Área, chegando mesmo a modificar conceitos atribuídos por elas aos programas $^{36}$.

A crítica feita pelos autores, que participaram ativamente do processo $^{37}$, é que, mesmo as comissões levando em consideração as especificidades das áreas ao avaliarem seus programas, o CTC homogeneizou as análises com base nos critérios das Áreas hegemônicas, como as de Ciências Exatas e da Terra e de Ciências Biológicas.

O resultado da avaliação trienal 2001 mostra que havia uma forte concentração dos programas com conceito 7 (sete) nessas duas grandes Áreas $(61,2 \%)$, embora eles representassem apenas $21,6 \%$ dos programas avaliados. No entanto, dos 29 programas que tiveram seus conceitos 7 (sete) e 6 (seis) rebaixados, 15 deles (52\%) eram da Grande Área de Ciências Humanas (GACH), especialmente Educação e Geografia, que somaram 12 programas ou $41 \%$ do total de cursos rebaixados.

Assim, no segundo triênio de avaliação continuada (trienal 2004), houve uma luta pela hegemonia das áreas no interior do CTC, com o embate travado pela Área da Educação e as demais Áreas de Ciências Humanas (GACH), especialmente a de Geografia, para terem seus critérios e especificidades assegurados nas Fichas de Avaliação. A GACH se articulou para estabelecer critérios para avaliar os cursos 6 e 7, assentando-os em três bases: a) formação, b) corpo docente e c) pesquisa e produção científica com inserção internacional. Além disso, buscou alianças com representantes das Áreas de Ciências Sociais Aplicadas, Letras e Linguística e Música e Artes, visando à construção de critérios comuns, o que resultou numa reunião do grupo que se denominou como Grande Área de Humanidades. O relatório dessa reunião estabeleceu o entendimento do nível de excelência dos programas de humanidades e apontou o lugar central que os livros deveriam ocupar na avaliação dos programas dessa Grande Área, por constituírem uma forma apropriada de expressão e divulgação de seus produtos científicos (HORTA; MORAES, 2005).

\footnotetext{
${ }^{36}$ Ao final do processo da avaliação do triênio 1998-2001, dos 1545 programas avaliados pelas comissões de área, 41 deles tiveram seus conceitos rebaixados pelo CTC (sendo que 76\% deles situavam-se na faixa dos conceitos 6 e 7) e 3 tiveram seus conceitos aumentados.

37 José Silvério Baía Horta foi representante da Área da Educação no período 1999-2001 e representante da Grande Área de Ciências Humanas (GACH) no CTC (2000-2001) e, no triênio seguinte, como membro da comissão de avaliação. Maria Célia Marcondes de Moraes foi representante adjunta (1999-2001) e representante de Área (2002-2004).
} 
A classificação dos periódicos na Área da Educação pelo Sistema Qualis, em 2001, resultou de uma parceria entre os representantes da Área e a Anped. Uma comissão foi montada para que desse prosseguimento à classificação dos periódicos conforme critérios, tais como:

[...] normalização, publicação, circulação, autoria e conteúdo e gestão editorial - acrescidos de uma ficha de impacto encaminhada a especialistas para definir os periódicos que teriam padrão internacional. (SOUSA; MACEDO, 2009, p. 260).

Segundo essas mesmas autoras, o número de periódicos classificados dentro do Qualis passou de 608 na avaliação trienal 2004 para 1.308 na avaliação trienal 2007, sendo 232 periódicos os que concentravam $80 \%$ da produção da Área da Educação. No ano de 2004, no processo de avaliação dos programas no triênio, foi realizada a elaboração do Qualis/Eventos, do Qualis/Periódicos e dos critérios de recomendação de livros para a Área de Educação. A partir de então, houve a inclusão de livros e de capítulos de livros na avaliação da produção intelectual, para os programas da Área. Ainda em 2004, a GACH especificou os critérios para a Qualificação de produção bibliográfica e artística de excelência.

O Relatório de Avaliação da Área de Educação (CAPES, 2004) registra que o comitê utilizou os documentos produzidos no período, definidores dos conceitos sobre "área de excelência", "inserção internacional” e "padrão internacional" ${ }^{38}$, observando a tendência à consolidação dos programas da Área, que manteve o nível elevado de publicações qualificadas. $\mathrm{O}$ documento apontou, no entanto, que a produção poderia ser aprimorada, inclusive nos programas considerados de excelência. As recomendações aos programas foram no sentido de constituir e manter um forte núcleo de docentes permanentes ${ }^{39}$; de incentivar

\footnotetext{
${ }^{38}$ São eles: A) Documento da Grande Área de Ciências Humanas, que resume as conclusões de uma reunião realizada em Brasília em 26/6/2002 e define os critérios de excelência da Grande Área de Humanas, cujo perfil não está claro. Melhorar o apoio no tripé constituído por formação, corpo docente e pesquisa e produção científica com inserção internacional. B) Documento Inserção Internacional e Padrão Internacional, aprovado pelo Conselho Técnico e Científico (CTC) da Capes em reunião de 30/07/2003, o qual definiu conceitos e critérios gerais sobre inserção internacional e padrão internacional. C) Documento Relatório da Reunião da Grande Área de Humanidades (Âreas de Humanas, Ciências Sociais Aplicadas, Letras e Linguística, e Artes), que resume as conclusões do encontro realizado em Florianópolis, SC, em 3 e 4 de abril de 2003. D) Adendo ao documento anterior, emitido em reunião realizada em Brasília em 11/05/2004, que especifica os critérios para a Qualificação de Produção Bibliográfica e Artística de Excelência, com padrão internacional, justificadora da indicação dos conceitos 6 e 7. E) Documento de índices para a avaliação trienal de 2004, produzido pela Grande Área de Ciências Humanas em 22 e 23 de junho de 2004.

${ }_{39}$ Respeitando as condições estabelecidas pela Área a partir da Portaria 068 da Capes e evitando dependência, ainda que parcial, de docentes que não preencham essas condições.
} 
um maior intercâmbio e debate entre os pesquisadores da Área no Brasil; e de se estabelecer políticas de intercâmbio de teses e dissertações.

Nas avaliações subsequentes, correspondentes aos Triênios 2007, 2010 e 2013, a Área da Educação aprimorou seus critérios de avaliação e se fortaleceu, mas aumentou apenas parcamente o número total dos programas com nota 6 considerados de excelência, como pode ser observado no quadro 5.

\section{Quadro 5: Proporcionalidade de Programas de Excelência na Área da Educação nas avaliações trienais (2001 a 2013)}

\begin{tabular}{|l|c|c|c|c|c|}
\hline \multicolumn{1}{|c|}{ Programas } & $\begin{array}{c}\text { Trienal } \\
\mathbf{2 0 0 1}\end{array}$ & $\begin{array}{c}\text { Trienal } \\
\mathbf{2 0 0 4}\end{array}$ & $\begin{array}{c}\text { Trienal } \\
\mathbf{2 0 0 7}\end{array}$ & $\begin{array}{c}\text { Trienal } \\
\mathbf{2 0 1 0}\end{array}$ & $\begin{array}{c}\text { Trienal } \\
\mathbf{2 0 1 3}\end{array}$ \\
\hline Total geral & 54 & 68 & 78 & 95 & 121 \\
\hline Programas nota 6 & 4 & 4 & 5 & 5 & 6 \\
\hline Programas nota 7 & 0 & 0 & 0 & 3 & 3 \\
\hline Programas de excelência & 3 & 4 & 5 & 8 & 9 \\
\hline $\begin{array}{l}\text { Percentual de Programas } \\
\text { de Excelência }\end{array}$ & $5,5 \%$ & $5,8 \%$ & $6,4 \%$ & $8,4 \%$ & $7,4 \%$ \\
\hline
\end{tabular}

Fonte: Relatórios de Avaliação (2001 a 2013).

O número de programas de excelência vinha aumentando ao longo dos anos em termos absolutos, tendo passado de 3 (na trienal 2001) para 9 (na trienal 2013). No entanto, entre os triênios de 2010 e de 2013 registra-se uma queda em termos percentuais no grupo de programas de excelência, que passa, respectivamente, de $8,4 \%$ para $7,4 \%$.

Apesar disso, a Comissão de Avaliação da Área da Educação aponta uma melhoria na qualidade dos programas e a relaciona a reestruturações que a Área vem implantando na última década, o que inclui uma maior organicidade dos programas (organização das atividades em torno das linhas de pesquisa), a melhoria nos níveis de produção (docente e discente) e uma maior qualificação dos veículos que publicam a produção intelectual da pós-graduação. O documento também aponta a necessidade de produção de indicadores que permitam aperfeiçoar o processo avaliativo no que diz respeito à gestão dos programas, objetivo com o qual esta pesquisa procura contribuir.

As questões priorizadas na Avaliação da Capes são sistematizadas nas Fichas de Avaliação. Ao analisar as fichas da Área da Educação ao longo do 
período que corresponde às cinco últimas avaliações trienais (de 2001 a 2013), podemos verificar que as discussões da Área da Educação, na GACH e no CTC, provocaram mudanças no peso dos quesitos que compõem a avaliação dos programas. O quadro 6 e o gráfico 4 mostram os quesitos que compuseram as fichas de avaliação, seus respectivos pesos e distribuição ao longo das diferentes avaliações.

\section{Quadro 6: Evolução dos quesitos das Fichas de Avaliação da} Área da Educação nas avaliações trienais (2001 a 2013)

\begin{tabular}{|l|c|c|c|c|c|}
\hline \multirow{2}{*}{\multicolumn{1}{c|}{ Quesitos }} & \multicolumn{5}{c|}{ Pesos dos Quesitos } \\
\cline { 2 - 7 } & $\mathbf{2 0 0 1}$ & $\mathbf{2 0 0 4}$ & $\mathbf{2 0 0 7}$ & $\mathbf{2 0 1 0}$ & $\mathbf{2 0 1 3}$ \\
\hline Proposta do Programa & 0 & 0 & 0 & 0 & 0 \\
\hline Corpo Docente & 15 & 15 & 30 & 15 & 15 \\
\hline Atividade de Pesquisa & 20 & 20 & & & \\
\hline Atividade de Formação & 15 & 15 & & & \\
\hline Corpo Discente & 10 & 10 & & \multirow{2}{*}{35} & 35 \\
\hline Teses e Dissertações & 20 & 20 & & & \\
\hline Produção Intelectual & 20 & 20 & 30 & 35 & 35 \\
\hline Inserção Social & & & 10 & 15 & 15 \\
\hline Soma dos Pesos & 100 & 100 & 100 & 100 & 100 \\
\hline Fonte: Capes, Documentos de Ârea (2001 a 2013). & \\
\hline
\end{tabular}

Gráfico 4: Evolução dos quesitos das Fichas de Avaliação da Área da Educação nas avaliações trienais (2001 a 2013)

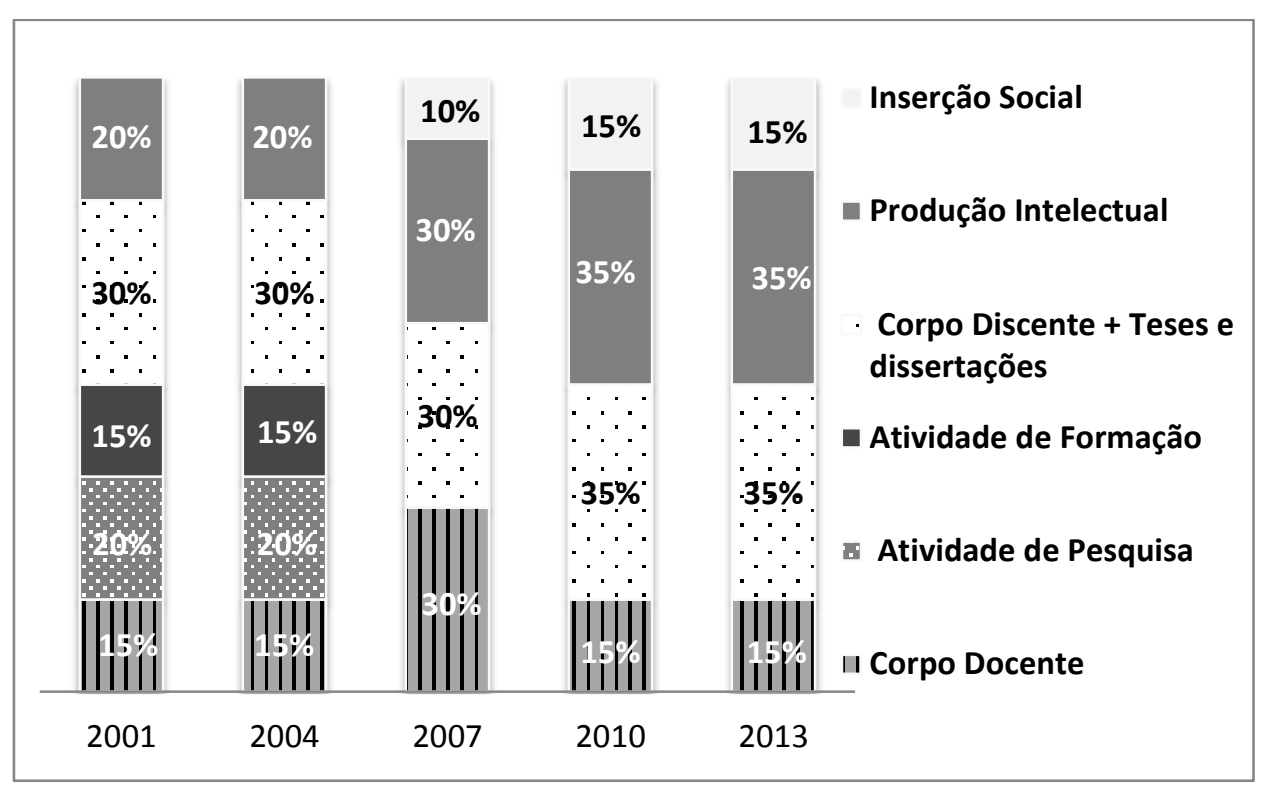

Fonte: Capes, 2013. 
Observando conjuntamente o quadro 6 e o gráfico 4, podemos fazer algumas constatações. Primeiramente, é preciso apontar que, nas Avaliações Trienais 2001 e 2004, eram sete os quesitos que compunham a ficha: (a) proposta do programa; (b) corpo docente; (c) atividade de pesquisa; (d) atividade de formação; corpo discente; (e) teses e dissertações; e (f) produção intelectual. A partir da avaliação trienal 2007, passaram a compor a ficha cinco quesitos: (a) proposta do programa; (b) corpo docente; (c) corpo discente, teses e dissertações; (d) produção intelectual e (e) inserção social.

Cada um desses quesitos, por sua vez, é formado por itens, aos quais também são atribuídos diferentes pesos, que também variaram ao longo dos triênios. Aqui, vamos nos ater às mudanças expressas nos documentos em relação a cada quesito e seus pesos, analisando o que essas mudanças podem indicar.

O quesito "Proposta do Programa" permaneceu em todas as avaliações e nunca contou ponto. Ele é bastante descritivo e serve para dar aos avaliadores uma contextualização das características particulares de cada programa. Com base na Proposta do Programa, são analisadas questões como a coerência entre linhas e projetos, a consistência curricular, a infraestrutura e o planejamento do programa.

O quesito "Corpo Docente" também se manteve em todas as avaliações e teve peso 15 na maior parte delas. A exceção ocorreu na avaliação trienal 2007, quando teve peso 30. Nas avaliações anteriores, o quesito Corpo Docente se referia a questões como a composição, a atuação, a dedicação e a qualificação dos professores. A partir de 2007, passou a abarcar também questões como compatibilidade e integração dos docentes com a Proposta do Programa, participação em pesquisa e desenvolvimento de projetos, participação na graduação, entre outros.

Os quesitos seguintes, "Atividades de Pesquisa" (com peso 20) e "Atividades de Formação" (com peso 15), foram eliminados a partir da avaliação 2007. Em Atividade de Pesquisa era avaliada a vinculação entre projetos, linhas e a dimensão do corpo docente, entre outras questões. Por sua vez, o quesito Atividades de Formação tratava da estrutura curricular e da distribuição da carga letiva e dos orientandos entre os docentes. Boa parte das questões presentes nesses quesitos, portanto, referia-se a temas relacionados ao corpo docente e foi incorporada posteriormente a esse quesito. 
Tendo em vista essa perspectiva, podemos fazer outra leitura do peso dado à atividade docente ao longo do período. Na avaliação 2001, os quesitos Corpo Docente, Atividades de Pesquisa e Atividades de Formação representavam, conjuntamente, $50 \%$ do peso da avaliação dos programas. Eles foram perdendo centralidade ao longo do tempo, e atualmente estão incorporadas no quesito Corpo Docente, que representa apenas $15 \%$ do peso total da avaliação ${ }^{40}$.

Em contrapartida à diminuição do peso do Corpo Docente, o quesito "Produção Intelectual", que se refere à quantidade e qualidade de publicação do corpo docente, foi ganhando peso ao longo das avaliações. Em 2001 tinha peso 20, passou para $30 \mathrm{em}$ 2007, e para peso $35 \mathrm{em} 2010$.

Os quesitos "Corpo Discente" (peso 10) e "Teses e Dissertações" (peso 20), foram aglutinados a partir da avaliação trienal 2007 no quesito "Corpo Discente, Teses e Dissertações" (peso 30), que também teve seu peso aumentado a partir da avaliação 2010, quando passou a representar 35\% do total da avaliação. O quesito Corpo Discente, Teses e Dissertações avalia a titulação de mestres e doutores (em quantidade e prazo). Uma boa parte do quesito $(40 \%)^{41}$, entretanto, refere-se também à produção intelectual discente, verificada através da publicação qualificada. Assim, o cálculo de proporcionalidade ${ }^{42}$ permite afirmar que, $14 \%$ dos $35 \%$ do total do peso do quesito, se referem à produção intelectual.

Desse ponto de vista, a produção intelectual do programa (de docentes e discentes) passa a ser o de maior peso, correspondendo a $49 \%$ da avaliação do programa. Assim, podemos afirmar que a publicação intelectual é o fator de maior impacto na avaliação dos programas. O quesito produção intelectual, portanto, vem ganhando peso maior, o que reflete a sua importância crescente nas avaliações, que consideram enfaticamente a produção reconhecida pelos pares, especialmente na forma de artigo, como o produto central da pós-graduação. Esse é um dos aspectos do Sistema de Avaliação da Capes bastante discutido, e que ainda recebe críticas de parte dos acadêmicos.

\footnotetext{
${ }^{40}$ Um dos itens que compõem o quesito "corpo docente" atualmente é o "2.2. Adequação e dedicação dos docentes permanentes em atividades de pesquisa e formação no programa."

${ }^{41}$ Item 3.3 do quesito "Corpo Discente, Teses e Dissertações" das avaliações trienais 2010 e 2013: Qualidade das Teses e Dissertações e da produção de discentes autores da pós-graduação e da graduação (no caso de IES com curso de graduação na área) na produção científica do programa, aferida por publicações e outros indicadores pertinentes à área (peso 40).

${ }^{42}$ Para o cálculo foi utilizada a seguinte equação: $x=35.40 / 100$, sendo que " $x$ " corresponde ao peso dos quesitos relacionados diretamente à produção discente.
} 
O quesito "Inserção Social do Programa", por sua vez, foi incluído na avaliação 2007, com peso 10 e ganhou mais peso na avaliação 2010, quando passou a ter peso 15. Esse aumento pode ser considerado uma resposta a críticas anteriores não só da Área da Educação, mas de todas as Áreas das Ciências, Humanas Sociais e Aplicadas ao sistema de avaliação, que apontavam para o fato de a avaliação não valorizar a inserção e o impacto regional e (ou) nacional do programa, a sua integração e cooperação com outros programas e centros de pesquisa e, ainda, a visibilidade ou transparência dada pelo programa à sua atuação.

Em conjunto, a absorção de antigos quesitos, como "Atividade de Pesquisa" e "Atividade de Formação", em um novo tópico com peso menor, a diminuição relativa do peso do Corpo Docente, assim como o aumento do peso de quesitos como "Produção Intelectual" e "Corpo Discente, Teses e Dissertações" e a inclusão do quesito "Inserção Social do Programa" revelam a existência de uma solução de compromisso e de concessões mútuas entre a Capes e a Área de Educação, que é fruto das lutas que foram travadas no campo da pós-graduação em educação em relação ao que deve ser considerado como mais relevante na avaliação dos programas da Área.

No próximo capítulo, discutiremos como os agentes entrevistados na pesquisa se relacionaram, no contexto da prática, com as questões decorrentes da política de avaliação realizada pela Capes. 


\section{5.}

\section{Contexto da prática: relação dos coordenadores com a política}

O contexto da prática é aquele no qual a política está sujeita à interpretação e recriação, o que produz efeitos e consequências que podem representar mudanças e transformações significativas na política original (BOWE; BALL; GOLD, 1992).

Ao analisar as experiências dos quatro Programas de Excelência selecionados pela pesquisa (PUCRS, Uerj, UFMG e Unisinos), procuraremos entender como os produtos dos contextos de influência e de produção de textos da Política Brasileira de Pós-Graduação foram interpretados e "traduzidos em ação" no "contexto da prática" em cada um dos casos. Na análise do contexto da prática, nos interessa perceber como as diretrizes propostas no nível macro (Estado/Capes) foram reinterpretadas no nível micro (programas de mestrado e doutorado) e quais as estratégias adotadas pelas coordenações para lidar com essas injunções.

Em nosso estudo, a arena em que a política é colocada em ação são os programas de pós-graduação selecionados e os sujeitos privilegiados pela pesquisa são os coordenadores de curso que atuaram neles a partir de 2001. Buscamos compreender como eles desenvolvem suas próprias interpretações da política proposta, as estratégias que adotam para traduzir essa política em ação e as semelhanças e diferenças que ensejam suas interações. De acordo com os objetivos da pesquisa, o foco da nossa análise é o trabalho de gestão dos quatro programas e sua contribuição para os resultados ascendentes apresentados na avaliação da Capes.

Optamos por organizar a análise do contexto da prática a partir de três temas que permitem perceber as diferenças e semelhanças existentes nas quatro experiências: (1) relação dos coordenadores com a avaliação da Capes, que aborda as percepções e críticas desses agentes em relação à avaliação; (2) dimensões contextuais da gestão dos programas, voltado para a análise dos fatores relativos ao contexto institucional que interferem na atuação dos coordenadores (forma de provimento ao cargo de coordenador, gratificação financeira, preparação para atuar na função e apoio técnico-administrativo); e (3) 
estratégias de ação dos programas, com destaque para a gestão coletiva dos programas e a mediação da política junto ao corpo docente e discente.

\section{1.}

\section{Relação dos agentes com a Avaliação da Capes}

A Avaliação da Capes afeta diretamente o cotidiano dos programas e, principalmente, o trabalho do coordenador, um agente que acaba por fazer a mediação entre as injunções do processo de avaliação e o corpo docente e discente do programa. Nesta pesquisa, nos interessou saber qual o posicionamento desses agentes diante do processo de avaliação e suas principais críticas.

Embora nos textos da política, em especial no Documento de Área e no Relatório da Avaliação Trienal, a excelência esteja estreitamente relacionada à publicação de nível internacional, os agentes apontaram também suas próprias interpretações sobre o que torna um programa "de excelência", como revelam os trechos dos depoimentos a seguir:

Eu tenho convicção de que o nosso Programa sempre foi de excelência, [...] o Programa ficou conhecido no Brasil, pois tinha uma massa de professores conhecidos como o [Jamil] Cury, o Neidson [Rodrigues], o Miguel Arroyo, o Walber, a Laura, a Magda Soares. Então, essa turma fez do Programa um Programa de Excelência. [...] o Programa tradicionalmente já teve linhas que eram muito ligadas aos movimentos sociais e uma linha de Alfabetização, que era a da Magda [Soares], e que eram todas linhas de excelência. [...] Nós estamos fazendo uma internacionalização que se preocupa não só com os grandes centros. Como, por exemplo, nós temos um doutorado em Angola, para uma sociedade que está começando a crescer na pósgraduação, nós estamos apoiando essa sociedade com esse doutorado. Então, nós temos o doutorado latino-americano que tem a mesma base que é apoiar [...]. (Coordenador E - UFMG).

Existe uma diversidade [de docentes] que não aceita se enquadrar completamente nos parâmetros e é paradoxal porque, do meu ponto de vista, acho que é essa diversidade [...] que gera também a riqueza, a qualidade. [...] Existem aqueles que são pesquisadores de ponta que dizem: "A docência é fundamental para mim". A docência na graduação. Entendeu? Então essas pessoas, elas estão do ponto de vista da sua atividade de pesquisador ou de professor do Programa, fazendo esforços diferentes para cumprir com as metas de qualidade, não é para ter um Programa de Excelência na pós-graduação. (Coordenador A - UFMG).

Foi um momento muito emocionante [quando veio o resultado da mudança de nota 4 para nota 6]. E aí, eu lembro que a gente escreveu uma poesia que era "Somos muito mais que 6". Começava assim: "Quantos alunos somos? Quantos professores somos? Quantos funcionários somos? O que temos defendido? Quantas dissertações?" E o eixo daquela atitude de fazer aquela espécie de poesia estava 
associado exatamente a isso: poder articular o quanto a gente tinha crescido como coletivo com a qualidade do Programa, sem restringir aquele momento na competição de "a gente alcançou 6". [...] Nós tínhamos uma parcela do grupo com uma experiência política e pautada por alguns valores de trabalho coletivo e de defesa da Educação e da qualidade da Educação. (Coordenador B - Unisinos).

Outro aspecto que foi possível observar sobre a relação dos programas com o tema da excelência é que, nas quatro experiências, em um dado momento, houve uma decisão do corpo docente, ou pelo menos de boa parte dele, de buscar a "excelência" acadêmica, mesmo sem necessariamente visar diretamente à chancela da Capes, em termos do reconhecimento propiciado pela obtenção das notas 6 ou 7. As coordenações dos programas tiveram papel importante nesse sentido.

A gente se colocou nessa tarefa de voltar a ser um Programa de Excelência. E nós tínhamos potencial pra isso. Porque, no Programa, a gente tem vários nomes que são bastante reconhecidos em suas áreas nacionalmente, hoje. [...] E aí, a gente se organizou e essa organização tem a ver com essa questão da coordenação que você fala. Porque, na verdade, o que a gente organizou foi uma coordenação com um plano claro para voltar a essa condição de excelência. (Coordenador E UFMG)

Essa comissão composta por [nomes dos membros da comissão coordenadora anterior] imprimiu um ritmo que não visava aumentar a nota, até porque isso ainda não estava muito claro nessa época. [...] Mas estava imbuído de um "espírito acadêmico". Assim, nós tivemos que mudar a postura de trabalho porque antes houve uma crise mesmo no Programa de "fogueira das vaidades". E isso gerou uma reação de "nós não querermos entrar nessa jogada", mas fazer alguma coisa aqui para realmente fazer a diferença. (Coordenador A - Unisinos).

Quando começa a ser produzida essa avaliação trienal da Capes, com esse modelo mais produtivista, o Programa começou a ficar espremido, os professores não se alinhavam direito com a mesma lógica de produção. Enfim, a gente começou a avaliar e a pensar que, se alguma coisa não fosse feita, o risco de cair a nota era bastante possível [...]. A ação foi imbuída no sentido de tentar definir em termos de planejamento mesmo que coisas a gente precisava atentar. [...] Uma coisa que a coordenação fazia era localizar esses editais para distribuir para os professores, induzi-los a submeter projetos e tal. Então teve essa intenção de fazer essa trajetória ascendente. (Coordenador C-PUCRS).

A busca por melhoria da qualidade também teria ocorrido de forma reflexiva. Foi interessante constatar que todos os coordenadores de programa apresentaram diversos argumentos em favor da Avaliação da Capes. Destacamos, a seguir, aqueles mais frequentes e relevantes. 
Em primeiro lugar, a maior parte dos coordenadores afirmou que $a$ qualidade atual da pós-graduação brasileira é consequência da avaliação realizada pela Capes.

No entendimento desses agentes, o processo de avaliação proporcionou, entre outros aspectos, a melhoria da qualidade da pesquisa, especialmente na Área da Educação:

Eu acho que, para Área de Educação, essa avaliação teve um papel muito importante. A Área de Educação não tinha uma característica de pesquisa, de uma preocupação de socialização do conhecimento, como ela hoje tem. Não estou querendo dizer que todos os problemas se resolveram. Não se resolveram. Nem que tudo foi por causa da Capes. De forma alguma. Outros movimentos aconteceram nesse meio do caminho que levaram a isso, mas a Capes teve um papel indutor. (Coordenador B - Uerj).

Esse também é o entendimento do dirigente do Forpred entrevistado nessa pesquisa: "Deve-se considerar que, de modo geral, a avaliação busca salvaguardar a qualidade da pós-graduação. A intenção é boa." (Dirigente Forpred).

Alguns coordenadores destacaram a importância do processo ser feito por pares e mencionaram que o mesmo tem credibilidade, por ser realizado com lisura e transparência, como indica o trecho a seguir:

Considero positivo o fato de ser uma avaliação feita pelos pares. Um processo que tem certa lisura, eu acho que ele tem transparência, eu acho que os critérios estão claros, as regras do jogo estão claras. (Coordenador C, da PUCRS).

Outro aspecto destacado nas falas dos entrevistados é a compreensão de que a Avaliação da Capes teria acabado por favorecer, também, o desenvolvimento da pesquisa em programas de instituições particulares, que sem a mediação da avaliação, tenderiam a focar as atividades da pós-graduação apenas no ensino:

[...] a PUC é uma Universidade que realmente compra a ideia de ser uma Universidade de excelência, mas eu já trabalhei em outras Universidades privadas onde a Capes "nos protegia", entendeu? Graças aos critérios da Capes, nós podíamos manter certos compromissos com a excelência, porque se não fosse a Capes, a Universidade, de fato, não bancaria uma série de coisas como o aperfeiçoamento dos professores no pós-doutorado, o limite de horas/aula, a manutenção de horas de pesquisa; a participação em congressos. Se a gente não tivesse os argumentos da Capes, a gente também internamente só daria aula, só ficaria em sala de aula, a pesquisa não aconteceria. (Coordenador A - PUCRS). 
Outro entendimento explicitado pelos coordenadores entrevistados foi no sentido de que o processo de avaliação proporciona um uso mais racional $e$ adequado do dinheiro público. A associação entre mérito e fomento na pósgraduação é vista com bons olhos por boa parte desses docentes. Nesse sentido, o Coordenador D, da UFMG afirma:

Eu acho que o fato de termos uma pós-graduação de excelência tem a ver com os processos de avaliação e os processos de indução subjacentes ao processo de avaliação e de financiamento.

Outro coordenador da UFMG tem uma apreciação positiva da política da Capes, que gostaria, inclusive, de ver estendida para os outros níveis de ensino: "De uma maneira geral, acho positivo. Adoraria que outras áreas, como a Educação Básica, tivessem uma avaliação constante e financiamento vinculado a isso." (Coordenador C - UFMG).

O dirigente da Anped entrevistado nesta pesquisa completa o raciocínio sobre a importância da relação entre avaliação e financiamento público:

Eu acho que o primeiro ponto de que ela parte é que é importante para a avaliação, ter um financiamento público. Você não pode distribuir recursos públicos sem saber se eles serão destinados para fonte segura, que os objetivos serão realizados. Isso a gente obtém por meio da avaliação. Então, a avaliação é um mecanismo importante para garantir isso. (Dirigente Anped).

Entre os coordenadores, entretanto, a questão do financiamento não é consensual. Alguns fazem críticas à associação entre mérito e fomento, alegando que ela pode causar uma injusta divisão dos recursos públicos, na medida em que favorece os programas e instituições mais bem estruturados, que conseguem atingir os critérios de qualidade com mais facilidade. Consequentemente, essa associação prejudicaria justamente os programas mais frágeis em termos de recursos e que, portanto, teriam mais dificuldade para atingir as metas estabelecidas. Esta situação, em parte, guarda relação com o objetivo de se buscar uma distribuição normal dos programas na escala das notas da Avaliação da Capes, que estabelece uma classificação hierárquica dos programas:

[A avaliação] é comparativa com os outros programas. Ela tem uma cota de programas que podem ser 7 , que podem ser 6 , que podem ser 5. Então, o fundamento da avaliação é hierarquizar, mesmo. Isso é que eu acho mais complicado: atrelar a avaliação ao financiamento. Isso significa para mim um grande erro. Um grande erro de você pegar um programa como esse no Maranhão [que a coordenadora visitara recentemente], por exemplo, que mais precisa, e ser o que ganha menos recurso. Então, eu sei e acho super complicado esse 
atrelamento. É uma avaliação claramente hierarquizante. (Coordenador B - UFMG).

O dirigente do Forpred também abordou esse aspecto em sua análise sobre o Sistema de Avaliação da Capes.

\begin{abstract}
Acho que esse é um fator de aumento da desigualdade regional e institucional dos programas de pós-graduação. Aqueles que estão em Universidades menores, em Universidades com menos recursos, tendem a ser penalizados e a avançarem com muita dificuldade. Os que estão em regiões mais privilegiadas economicamente e em Universidades com mais recursos, tendem a avançar e conseguir mais recursos, mais reconhecimento. Há uma espécie de dualidade estrutural que está ligada à região geográfica, ao prestígio acadêmico, aos recursos econômicos. (Dirigente Forpred).
\end{abstract}

Como foi mostrado no capítulo anterior, em especial, o PNPG 2010-2020 estabelece, como um de seus objetivos, diminuir as assimetrias entre as regiões e microrregiões. Para cumprir esse objetivo, entretanto, o documento aponta que é necessário olhar para as dificuldades de programas e Universidades que estão em posição mais difícil no conjunto da pós-graduação, de modo que elas possam avançar dentro da avaliação e, consequentemente, receber mais recursos (BRASIL, 2010).

Em relação a essa questão, um dos coordenadores da Área da Educação (CA-Edu A) entrevistados argumenta que, embora o Sistema de Avaliação da Capes coloque o mérito acadêmico em primeiro lugar, a contrapartida é que a própria Capes, e também o $\mathrm{CNPq}$, promove programas e editais dirigidos prioritariamente a regiões e temas específicos, visando minimizar as desigualdades.

\footnotetext{
Então a questão do mérito acadêmico está muito clara. No entanto, "você" não pode esquecer que existem outros programas que contemplam projetos de outras Instituições, de outras entidades que tiveram dificuldades. Então, todos os alunos de todos os programas de pós-graduação da região Norte tem bolsa. Entende? Não é pela qualidade só, mas são outros elementos. Há vários editais de fomento do CNPq só para a região Norte, Nordeste e Centro-Oeste. Então, na Área, de fato, elas estão relacionadas, mas existem vários problemas de fomento: só ganha quem tiver [...] há projetos, inclusive, em que se você não estiver filiado ao grupo de alguma Universidade do NorteNordeste você não ganha. Então, tem esses projetos de fomento também. (CA-Edu A).
}

Outra questão levantada pelos coordenadores em relação ao tema do financiamento refere-se ao fato das Áreas das Ciências Exatas e Naturais terem 
mais prestígio, poder acadêmico e capacidade para se beneficiar com mais recursos do que as Áreas das Ciências Humanas e Sociais:

As Áreas de Ciências Naturais têm preponderância no jogo da Capes [...] mais poder. Isso resulta em coisas que são importantes: bolsas. [...] Num curso de Física da UFMG, todo mundo que entra tem bolsa. Não tem ninguém que entra nesse curso que não tenha bolsa. $\mathrm{Na}$ Educação [...] nós somos um Programa 7, que tem 50\% dos alunos aprovados com bolsas. E desses 50\%, ainda tem o "Reuni" bolsa já que tem um viés no qual o aluno tem que trabalhar. Então, quer dizer, é muito difícil. Isso aí é o poder que as Áreas de Ciências Naturais têm e que nós não temos. E acho que isso seria até uma coisa ideal, se isso fosse mais ou menos um direito por igual para todo mundo. Por exemplo, a quantidade de bolsistas que tem na Área de Física no CNPq: hoje, eu acho que tem um bolsista para cada três professores de pós-graduação. Na Área de Educação tem um bolsista a cada dezesseis professores de pós-graduação. Todos esses parâmetros das Áreas de Ciências Naturais ganham porque elas têm mais poder. (Coordenador E - UFMG).

De fato, o artigo $4^{\circ}$ do Regulamento de Apoio à Pós-Graduação (Proap) ${ }^{44}$, define que o valor de referência para alocação de recursos financeiros para cada programa de pós-graduação é fixado em função da disponibilidade orçamentária da Capes e da cota de bolsas Demanda Social (DS), de acordo com o peso da natureza da área do conhecimento e nível de formação (mestrado ou doutorado). O quadro de pesos por área do conhecimento e nível, apresentado no regulamento $^{45}$, mostra que, enquanto Ciências Exatas e da Terra, Ciências Biológicas, Engenharias, Ciências da Saúde e Ciências Agrárias têm peso 4 para mestrado e 5 para doutorado; Ciências Sociais Aplicadas, Ciências Humanas e Letras e Linguística têm peso 2 para o mestrado e 3 para o doutorado.

$\mathrm{O}$ dirigente do Forpred, inclusive, mencionou durante a entrevista que uma das lutas do Fórum na Capes é no sentido de que Educação passe a ser considerada "prioridade um" para distribuição de bolsas e recursos.

Além do prestígio e do forte poder acadêmico das chamadas "ciências duras" no campo científico, a diferença de pesos entre as áreas pode estar relacionada à tendência mundial de investimentos em CT\&I e à formação de pessoal para os programas nacionais, previstos no atual PNPG (2010-2020). O

\footnotetext{
${ }^{43}$ O Programa de Apoio a Planos de Reestruturação e Expansão das Universidades Federais (Reuni) foi instituído pelo Decreto $\mathrm{n}^{\circ}$ 6.096, de 24 de abril de 2007, e integra o Plano de Desenvolvimento da Educação (PDE). Um dos objetivos do programa é ampliar o acesso e a permanência de alunos na educação superior.

${ }^{44}$ Portaria ${ }^{\circ} 64$, de 24 de março de 2010.

${ }^{45}$ Ver quadro completo no Anexo 3: Quadro de pesos por área do conhecimento e nível - Proap.
} 
PNPG aponta demandas em áreas como: energia, meio ambiente, defesa, transporte, produção de alimentos, biodiversidade, crescimento populacional, monitoramento meteorológico, utilização de recursos hídricos, e desenvolvimento de produtos e serviços. Esses temas, em sua maioria, estão mais diretamente relacionados com as Ciências Exatas e Naturais do que com as Ciências Humanas e Sociais.

A crítica ao uso de parâmetros das Ciências Exatas e Naturais na avaliação das Ciências Humanas e Sociais está presente na literatura sobre a avaliação da pós-graduação (SANTOS, 2003; AXT, 2004; MARCHLEWSK; SILVA; SORIANO, 2011), e foi um dos temas abordados nas nossas entrevistas. Essa crítica também esteve presente entre os coordenadores, como pode ser visto no seguinte trecho:

\begin{abstract}
Eu concordo e acrescentaria que o problema da homogeneização é que ela é pautada por uma hegemonia do modelo das Ciências Exatas. Esse é o problema. Eu não teria nenhum problema de pensar parâmetros, até globais, para todos os Programas de Educação. São todos muito parecidos e não vejo nenhum problema de homogeneizar por aí. O problema é que essa homogeneização segue parâmetros de uma área que não é nossa. Então, para a gente, é muito importante livro, mas para as Áreas Exatas e Médicas o livro já não existe. Então aí a gente sai perdendo. (Coordenador A - PUCRS).
\end{abstract}

Nesse sentido, o argumento dos coordenadores é de que a pesquisa é pautada pela lógica das Ciências Exatas e Naturais, cujos produtos são divulgados como maior facilidade, em função do tipo de conhecimento que produzem, e que essa lógica se contrapõe, em certa medida, ao modo de fazer ciência nas Ciências Humanas, especificamente, na Área da Educação.

\begin{abstract}
Eu vejo [os trabalhos de] muitos amigos na Física nos quais um pequeno experimento que deu certo é um artigo de três "pagininhas", de duas páginas. Enquanto em nosso caso, não é isso. Demanda mais tempo, mais reflexão. Então, o modelo é de outro campo mesmo. Nem é só das Ciências Biológicas, é da Física também. É em outra lógica que eles produzem! Não estou falando que não produzem, produzem muito e tudo, mas [...] eles vão lá e fazem um cálculo, escrevem uma "tira" de duas páginas e já têm um artigo publicado. (Coordenador B UFMG).
\end{abstract}

A maior parte dos coordenadores, contudo, vê a Área das Ciências Exatas e Naturais por outra perspectiva. Eles entendem que há um discurso "ressentido" na Área da Educação em relação a esse tema, que não é produtivo, e apontam caminhos mais "ativos" para enfrentar eventuais problemas gerados por essa 
situação. Esses coordenadores não veem necessariamente como negativa a adoção de critérios das Ciências Exatas, uma vez que se trata de áreas com mais tradição no campo científico, como podemos observar nas seguintes falas:

Eu acho que a Área [da Educação] acaba sendo destrutiva, porque ela projeta para si, sei lá, uma marca do ressentimento, não sei nem avaliar de onde. (Coordenador C - PUCRS).

Tem uma hegemonia da produção de conhecimento concebida numa ideia das chamadas Ciências Físicas e Biológicas? Sim. Mas isso, na epistemologia, nós temos que conseguir como Ciências Humanas, lutar politicamente para hegemonizar sob outras formas. Mas agora como é que eu vou fazer isso? Não vai ser chegando e dizendo "eles estão errados e nós estamos certos". Não é com essa dicotomia, no meu modo de ver. Tem que entrar "na vez", tem que saber conversar com eles, tem que saber negociar, tem que saber entender também porque "o cara" defende aquilo. (Coordenador B - Uerj).

As Ciências Exatas têm um peso maior, pois têm uma tradição de pesquisa mais consolidada. Por outro lado, a Área da Educação tem que avançar enquanto nova área de pesquisa. (Coordenador $\mathrm{C}-$ Unisinos).

É claro que hoje essa questão de enfatizar o periódico e deixar o livro com menos valor é uma influência das Áreas de Ciências Naturais e isso aí pesa dessa forma na produção. Agora, eu acho que, por outro lado, o surgimento do periódico na Área de Educação [...] é positivo! (Coordenador E - UFMG).

Outra crítica recorrente também na literatura em relação à Avaliação da Capes, que guarda relação com a crítica à hegemonia das regras das áreas científicas ditas "duras", diz respeito ao caráter homogeneizador do modelo (GATTI et al., 2003; AXT, 2004; HORTA, 2006). De acordo com essa crítica, o uso de critérios similares para diferentes áreas do conhecimento tem levado a uma homogeneização não apenas dos veículos de difusão da produção científica (periódicos, principalmente), mas também dos próprios trabalhos publicados. $\mathrm{Na}$ visão dos críticos, as especificidades de cada área, subárea, ou região dos programas devem ser levadas em consideração no processo de avaliação.

A maior parte dos coordenadores, entretanto, acha que é necessário e positivo o processo de padronização dos parâmetros da avaliação, de modo a propiciar a comparabilidade entre pesquisas e cursos, como afirma o Coordenador A - Uerj: "Um sistema que se pretende nacional deve determinar alguns parâmetros comuns." Por outro lado, parte dos coordenadores ressalta que a padronização dos parâmetros não homogeneíza necessariamente os resultados e produtos da pós-graduação: 
Eu acho que ele [o processo de avaliação] não é homogeneizador. Porque o parâmetro não determina quais vão ser as linhas de pesquisa, o parâmetro não determina quais serão os conteúdos, quais são os projetos. Eu acho que dá uma organização geral, que justamente garante a qualidade da pós-graduação porque eu sei que eu posso receber um aluno da PUC no meu Programa, como aluno especial, ou da UFRJ [...]. (Coordenador C - Uerj).

[O sistema] tem uma preocupação com uma formação de linha de pesquisa, isso pode ter certo caráter homogeneizador. Mas não tem, por exemplo, homogeneidade no que se refere aos enfoques de pesquisa. Os enfoques de pesquisa são extremamente diferentes. Diria assim: quando as pessoas falam que existe essa crítica, elas me apresentam poucos elementos. [...] Eu não consigo ver esse efeito homogeneizador tão significativo. (Coordenador B - Uerj).

Olhando, por exemplo, os três programas de excelência que são nota $7^{46}$, não consigo ver [homogeneidade]. Porque a PUC do Rio é completamente diferente da Uerj, que está do "seu lado". A UFMG é "quilômetros luz" diferente da Uerj. Então, eu não vejo homogeneidade nenhuma. E a PUC do Rio Grande do Sul é completamente diferente da Unisinos e atualmente as duas são 6. [...] $\mathrm{Eu}$ acho que os programas são muito fortes para se tornarem homogêneos, assim, de uma hora para outra. Eu não vejo que isso vá homogeneizar. Vai sim, estabelecer alguns patamares. (Coordenador A - Unisinos).

Outra categoria de análise é o produtivismo, que aparece com maior recorrência nas críticas ao processo de Avaliação da Capes. Com efeito, há coordenadores, especialmente nos Programas que funcionam em Universidades particulares, afirmando que o sistema é produtivista, o que acaba gerando a replicação de artigos científicos ou uma falta de respeito aos diferentes tempos de pesquisa.

A gente vive a síndrome da replicação dos artigos. Podem ser os pesquisadores mais famosos, ninguém mais tem condições de escrever trabalhos originais, completamente originais, e fazer o conhecimento avançar. Está todo mundo replicando, integralmente, parcialmente. Por quê? Porque a produtividade vem marcando uma mensuração muito quantitativa. Eu acho que esses indicadores de produtividade deveriam ser menos quantitativos e mais qualitativos e a gente teria, então, uma produção cientifica de mais qualidade. Essa é a minha critica. (Coordenador A - PUCRS).

Eu acho que tem um elemento produtivista num sentido negativo pelo fato de ter que homogeneizar e dar parâmetros de quantidade para todos. Se existe um problema de um professor num grupo de pesquisa, que até pela natureza, precise levar mais tempo pra terminar e ele precisa responder como o outro, então, nesse sentido, leva a uma banalização. (Coordenador B - Unisinos).

\footnotetext{
${ }^{46} \mathrm{Na}$ data em que foi realizada a entrevista, 22/03/2013, eram três programas de excelência na Área da Educação com nota 7 pela Capes: o Programa da PUC-Rio, o Programa da UFMG e o Programa da Uerj.
} 
Entretanto, tipicamente os coordenadores de programas de Universidades públicas entrevistados não concordam com a de crítica ao produtivismo. Em especial, eles discordam da ideia de que a valorização da quantidade se faz em detrimento da qualidade. Muitos dos entrevistados argumentaram que não há produtivismo na Área da Educação, visto que a produção docente, em termos de quantidade de artigos publicados por ano, é baixa. Alguns coordenadores atribuem essa crítica a uma espécie de lamentação da Área, como o Coordenador E UFMG, que aponta, em tom de brincadeira: "Essa questão do produtivismo, ela é um 'choro' da Área”.

Na Área de Educação não existe produtivismo. Ela é uma Área na qual a média de produção é 1 (um), acho que um produto docente por ano. Então, não existe produtivismo na Área de Educação do ponto de vista de cobrança da agência: seja CNPq ou Capes. A exigência para estar concorrendo a programa 6 , se eu não me engano, ainda permanece como 2, nível 2. Então, você não pode chamar de produtivista. (Coordenador B - Uerj)

[...] pensando nos critérios da Capes e do CNPq, as pessoas não precisam ter dez publicações por ano. Se elas têm não é por conta dos critérios da Capes ou do CNPq, têm por outras razões. Se elas tiverem duas boas publicações por ano, resolve. Isso para os programas 7, nós não estamos falando de programa 3. (Coordenador D - UFMG).

Assim, especialmente os coordenadores da UFMG consideram as metas de produtividade relativamente baixas e fáceis de atingir:

\begin{abstract}
Se você tem uma organização de laboratório, como eu te falei. Se você tem alunos, seus alunos [...] Um aluno de doutorado tem que produzir durante o tempo que ele está lá. Então, não tem porque "você" não ter dois produtos por ano. Porque com os alunos "você" tem. Então, eu posso até me dedicar a fazer, vamos supor, uma coisa que vai demandar mais tempo, vai demandar quatro anos, um produto meu. Mas eu posso me dedicar a isso porque, ao mesmo tempo em que eu estou fazendo, eu tenho os meus produtos saindo em função dos alunos. (Coordenador E - UFMG).

Tem que produzir? Tem. Tem que escrever? Tem que escrever. Mas tem que escrever vinte? Não, não tem. Tem que escrever um artigo, em uma boa revista por ano. Não é nada! Para quem está começando talvez seja difícil, mas para quem está no processo, para quem tem orientandos [não]. (Coordenador C - UFMG).
\end{abstract}

No caso da crítica ao produtivismo, é possível perceber uma diferença entre os coordenadores das universidades publicas e das universidades privadas. Nossa hipótese é que, por se tratarem de coordenadores que participam de um arranjo institucional que está inserido na estrutura do Estado, em universidades 
públicas federal e estadual, e, que, sendo servidores públicos concursados, podem fazer parte do jogo e ocupar uma posição de dominância no campo, com mais estabilidade e independência que os agentes das Universidades privadas. Essa posição faz com que eles consigam atingir os níveis de produção demarcados pela avaliação com mais facilidade e mantendo, inclusive, certo distanciamento crítico em relação às políticas da Capes.

Sobre a oposição quantidade versus qualidade, alguns coordenadores reconhecem ser bastante difícil determinar a qualidade tanto dos programas como das publicações dos docentes.

Como [ponto] negativo eu considero a dificuldade do rankeamento, a contabilidade. Não dá para contar todos esses fatores para fazer justiça, é inviável. Poderia haver um leque de parâmetros maior, mais possibilidades de avaliação. É uma situação delicada. Eu me coloco na situação de programas com nota inferior, que estão com dificuldade em avançar, fica difícil saber por que. Outra situação delicada: como pontuar? Como dar peso aos diferentes tipos de publicação? (Quanto vale um livro? Um artigo? Um capítulo?). (Coordenador C Unisinos).

Não acho que [a quantidade] esteja em detrimento da qualidade. Eu acho que é sempre difícil avaliar a qualidade, são coisas muitas vezes formais, mas acho que há um esforço. Quem tem uma fórmula para dizer como é avaliar um artigo? Vai depender do impacto. Às vezes, impacta em dez anos [...]. (Coordenador C - UFMG).

O Sistema Qualis tem sido a forma encontrada pela Capes para minimizar o problema da determinação da qualidade dos produtos bibliográficos. A utilização do Sistema Qualis como uma forma adequada de aferir qualidade, entretanto, não é consensual. Alguns entrevistados consideram o Qualis um caminho adequado, um indício de que a Capes têm se preocupado em aperfeiçoar os mecanismos para aferir a qualidade da produção intelectual dos programas, o que indicaria uma ênfase maior no aspecto qualitativo da produção docente do que na sua quantidade:

[...] a comunidade cientifica está muito atenta para não reproduzir isso de que a quantidade é mais importante que a qualidade. As sociedades científicas não “jogam” nisso. Então, quando a gente, por exemplo, faz a avaliação dos periódicos, nós estamos justamente dizendo que não adianta quantidade. Por que a gente avalia os periódicos? Porque nós sabemos que o critério de avaliação dos periódicos é um critério qualitativo para publicar esse ou aquele artigo, então nós temos aí uma dimensão qualitativa. (Dirigente Anped).

Por exemplo, ter um artigo em uma revista A, é qualidade. Posso até questionar a revista (se ela não é pontual ou outra coisa), mas, por que ela pode ser A? Se ela tem um alcance internacional, ou seja, abre o espaço para o diálogo com outro país, eu acho que tem uma diferença. 
A revista $\mathrm{B} 4$, que está dialogando com a região, ela tem seu valor. As duas têm qualidade, não tem só produtivismo. (Coordenador A Unisinos).

Eu vejo que está havendo uma mudança de quantidade para qualidade. Vejo que, por exemplo, certos editais procuram saber quais as cinco publicações mais importantes do pesquisador ao invés de ficar contando a quantidade de publicações. Isso é um indicador importante de que a coisa está mudando. Do que adianta eu ter vinte publicações B3 ou B4? Não seria melhor eu ter menos publicações, mas mais publicações A1, A2? A quantidade foi importante em um determinado momento, mas agora o foco está indo para a qualidade. (Coordenador $\mathrm{C}$ - Unisinos).

Os coordenadores também apontam que a classificação dos livros foi uma conquista da Área da Educação:

[...] "Qualis" para livros eu acho que foi um ponto positivo. Isso, se você parar para ver na avaliação, aumentou muito a produção, agora não é só isso que entra, você tem a questão dos alunos [...] e uma série de outros fatores. (Coordenador C - Uerj).

[...] flexibilidade para as áreas, eu acho que tem. Em primeiro lugar, eu acho que tem! Então, por exemplo, algumas áreas consideram o congresso, outras não. Umas áreas [...] essa abertura que teve, por exemplo, para os livros, que na cabeça de Física não faz o menor sentido. Então não acho que não é tão homogêneo não. (Coordenador C - UFMG).

Outros coordenadores, entretanto, fazem críticas ao sistema, considerando-

o hierárquico e restritivo, visto que há limite para publicações nos extratos mais elevados:

Eu acho que sim, eu acho que é difícil porque as metas estão sempre indo para cima. A Capes, ela vai ajustando tudo para cima, de certa forma. Tem uma, a gente vive um, digamos, um afunilamento dos espaços de publicação. Acho que somos uns 112 programas, no Brasil. A Área da Educação é uma Área numerosa. Você imagina todos esses professores sofrendo essa pressão, a mesma pressão por publicação em periódicos qualificados? O que chega nessas revistas? Atualmente, está demorando um ano para você conseguir publicar. Nós temos uma revista Qualis A2, a gente sabe o fluxo que essa revista tem, é uma coisa incrível. Chega muito trabalho. Então, eu acho que a gente vive um afunilamento, uma exigência de publicação, e não temos tantos canais assim de publicação nesses periódicos qualificados. Tem um estrangulamento aí. E, então, claro que isso é difícil de manter [...]. (Coordenador A - PUCRS).

Eu acho que é muito difícil para os professores e pesquisadores novos entrarem e conseguirem publicar no Qualis A. A tendência é, se for feito um levantamento, encontrar algumas pessoas que estão eternamente [no Qualis A], que sempre tem. (Coordenador C - Uerj).

Por fim, a análise da categoria produtivismo nos conduz ao encontro de uma questão que parece estar afligindo a maior parte dos entrevistados. Eles 
acreditam que as críticas ao produtivismo decorrem da sobrecarga de trabalho a que estão submetidos os professores nas Universidades. Essa sobrecarga, entretanto, não seria fruto da necessidade de atingir um grande número de produtos bibliográficos no triênio da avaliação, mas sim do acúmulo de uma série de funções que esses profissionais precisam desempenhar concomitantemente à docência e à pesquisa:

Os critérios CNPq e Capes para pessoas, pesquisadores, eles são muito razoáveis. O problema é que a nossa estrutura não nos deixa ser pesquisadores. Somos muito mais administradores, damos muitas aulas na graduação. Para darmos aula seriamente na graduação, nós temos de 8 a 12 aulas [a cumprir], via de regra, nas [Universidades] federais. Isso significa você gastar mais de 10 a 12 tempos para preparar a aula, para corrigir trabalho. Ou seja, metade do nosso tempo é dedicada a isso. Você separa mais um pouco disso, mais um terço das nossas 40 horas, para administrar a Universidade e você vai contando o que você precisa fazer. Você não tem tempo para fazer pesquisa e não tem tempo para escrever e etc. Então, essa circunstância que eu acho que é mais danosa e não os critérios da Capes e do CNPq. (Coordenador D - UFMG).

A condição de ser multitarefa hoje. Hoje, todo mundo tem que fazer tudo e mais algumas coisas, muita coisa e com muita diversidade. $\mathrm{Tu}$ tens que gerir um convênio, tu tens que coordenar um grupo, tu tens que editorar uma revista, dar aula. Quer dizer, têm tarefas diferentes, papéis diferentes, que se sobrepõem no dia a dia. Então, isso eu acho que cai como uma coisa muito pesada na rotina. $\mathrm{E}$ isso aí somado à perspectiva dessa prática produtivista, isso estressa. É a coisa que mais estressa. (Coordenador C - PUCRS).

Primeiro, porque é muito trabalho aqui na Faculdade. Na Uerj, nós ainda temos uma carga grande na graduação. Então, é muito trabalho, eu acho que os alunos orientandos da graduação e da pós-graduação, como tem várias comissões, tem projetos, as pessoas têm muitos projetos externos. Então, eu acho que a grande dificuldade é a demanda de trabalho mesmo, o mercado de trabalho mesmo. (Coordenador C - Uerj).

Entre as outras tarefas relatadas pelos coordenadores estão, portanto, aulas na graduação, gestão de convênios, coordenação de grupos, editoração de revistas, e ainda, tarefas relacionadas à administração da Universidade.

\section{2.}

\section{Dimensões contextuais da gestão nos programas}

Segundo Ball et al. (2012) as dimensões contextuais têm grande impacto no processo de colocação das políticas em ação. Essas dimensões dizem respeito a um conjunto de condições objetivas e a suas relações com uma série de dinâmicas 
interpretacionais subjetivas, que acontecem no nível institucional. Podem ser citados como exemplos de dimensões contextuais: o cenário local e o histórico da instituição (contextos situados); os valores, compromissos e experiência dos agentes (culturas profissionais); a equipe de trabalho, o orçamento e a infraestrutura (contextos materiais); e, ainda, o apoio e/ou pressão de órgãos aos que a instituição está subordinada (contextos externos).

Assim, optamos por procurar entender, primeiro, as condições objetivas das dimensões contextuais da gestão dos programas investigando, junto aos entrevistados, alguns aspectos relacionados com as culturas profissionais e os contextos materiais. Mais especificamente, buscamos entender aspectos relativos à ocupação do cargo de coordenador, tais como: a forma de provimento ao cargo de coordenação, a preparação recebida para atuar no cargo, a gratificação financeira e o apoio técnico para o exercício desta função.

\subsection{1.}

\section{Provimento ao cargo de coordenador do programa}

No âmbito dos estudos sobre as escolas de ensino básico, há um fértil debate sobre o provimento ao cargo de gestão (diretor escolar) alimentado por uma série de autores (BASTOS, 1999; MENDONÇA, 2000; FREITAS; PILLAS, 2006) que defendem que a forma de acesso a esse cargo pode influenciar atuação da direção na escola. A indicação é a forma de acesso mais criticada, em razão do histórico clientelismo político brasileiro e da relação de dependência e troca de favores entre pessoas e grupos sociais que marca a ação pública. Por sua vez, o concurso público tem argumentos a favor, como a coibição do clientelismo, a objetividade, a igualdade de oportunidades e a escolha pautada nas competências requeridas para o cargo. Por fim, a eleição é apontada como a forma de escolha mais democrática de participação da comunidade escolar.

Todas as formas de provimento do cargo de diretor na Educação Básica são, no entanto, objeto de críticas. As críticas apontam que a eleição nem sempre é garantia de democratização da gestão e outras formas, como a indicação ou o concurso, podem operar dentro de um contexto de reformas que contribua com a 
melhoria da qualidade educacional e, portanto, também para a democratização do ensino $^{47}$.

Se de fato existe pouco consenso em relação à qual seria a forma de provimento mais adequada, há, no entanto, um maior acordo em torno da necessidade de se investir na formação dos gestores, uma vez que eles enfrentam desafios de diferentes ordens em sua atuação profissional para os quais geralmente não tiveram preparo em sua formação pedagógica.

O desenvolvimento que, embora emergente, atingiram o debate e a pesquisa sobre o tema na Educação Básica, não encontra paralelo com relação, especialmente, ao provimento do cargo de coordenação e à formação de gestores no âmbito da pós-graduação, que não têm merecido a necessária atenção pelos estudiosos da área. Talvez isso se deva, em parte, à herança da nossa tradição catedrática, em que a atuação do professor/pesquisador é vista como a atividade central da pós-graduação. As funções relacionadas à gestão são menos prestigiadas e, portanto, também pouco debatidas e estudadas.

Ao consultar os regulamentos dos programas selecionados percebemos uma primeira diferença entre os programas das Universidades públicas e privadas. Com efeito, enquanto nos programas da Uerj e da UFMG o provimento se dá por meio de eleições, nos da PUCRS e da Unisinos, ele ocorre por meio de indicação.

Na Uerj, a eleição é direta, por meio de voto dos professores, funcionários e alunos do Programa, conforme a deliberação 042/2010

\begin{abstract}
Art. $6^{\circ}$ - O Coordenador Geral e o Vice Coordenador são eleitos pelo voto direto dos professores, funcionários e alunos em exercício do Proped, sempre de acordo com os critérios dispostos na Lei de Diretrizes e Bases acerca da matéria, e na proporção definida pelos mandamentos universitários vigentes por ocasião da eleição, garantindo-se um mínimo de $70 \%$ para o corpo docente.
\end{abstract}

Na UFMG, por sua vez, a eleição é indireta, já que é o colegiado, eleito pelos professores do Programa, quem elege o coordenador, conforme consta em

\footnotetext{
${ }^{47}$ Como exemplos peculiares de provimento ao cargo de diretor, temos o caso do município de Sobral, no Ceará, onde a partir de uma ampla reforma no ensino optou-se pela seleção por mérito dos diretores de escola, visando o fortalecimento da sua autonomia administrativa, financeira e pedagógica (BRASIL, 2005). Fora do Brasil, o caso de Chicago (EUA), na primeira fase de reformas iniciada em 1988, que tinha o localismo democrático como princípio para as mudanças, criaram-se conselhos escolares locais que contratavam os diretores por quatro anos e também tinham poderes para demiti-los (BRYK et al., 1998).

${ }^{48}$ Deliberação no 042/2010 - Aprova a reformulação do Programa de Pós-graduação em Educação, cursos de Mestrado Acadêmico e Doutorado.
} 
seu regulamento ${ }^{49}$, no Art. 12: "O Programa terá um Coordenador e um Subcoordenador, eleitos pelo Colegiado, dentre seus membros, por maioria absoluta".

O que foi relatado pelos coordenadores, entretanto, é que, na prática, um grupo de pessoas mais influentes no Programa (que compõem o grupo de excoordenadores do Programa, no caso da UFMG; ou que fazem parte do colegiado, no caso da Uerj) vai "costurando" um nome para ocupar o cargo quando se aproxima o fim da gestão. Podemos confirmar essa questão nas falas de dois dos coordenadores:

É uma eleição porque tem que ter uma eleição. As exigências são de eleição. Mas, na verdade, existe todo um período preparatório no qual a gente vai negociando entre nós quem pode ser. [...] Aí, a gente tem que ir cercando alguém [...] e vai convencendo as pessoas de maior influência sobre aquela pessoa. Conversa aqui, conversa ali e tal, e alguém assume. (Coordenador D - Uerj).

$\mathrm{Na}$ verdade, o nome é colocado por alguém. E o meu nome cresceu. [...] Não tive veto, não tinha concorrente, quer dizer, tinha outros nomes, mas não teve disputa de chapa. Então, houve uma construção política do nome que não foi eu quem fiz. (Coordenador A - UFMG).

Ao analisarmos o que ocorre nas instituições privadas, vemos que, no Programa da PUCRS, a indicação é feita pelo diretor da Faculdade de Educação, conforme consta em seu regulamento ${ }^{50}$ :

Art. $2^{\circ}$ - O Programa é dirigido por um Coordenador (Art. 93 do Regimento Geral da Universidade) com funções executivas, indicado pelo Diretor da Faculdade de Educação, aprovado pelo Pró-Reitor de Pesquisa e Pós-Graduação e nomeado pelo Magnífico Reitor da PUCRS, sendo este Coordenador assessorado por uma Comissão Coordenadora (Art. 94 do Regimento Geral da Universidade).

O regimento geral do Programa da Unisinos ${ }^{51}$ informa, em seu Art. $6^{\circ}$, que: “O Diretor da Unidade Acadêmica de Pesquisa e Pós-Graduação (UAPPG) indicará o Coordenador, a ser nomeado pela Reitoria”.

Embora no âmbito da regulamentação, os dois programas tenham os coordenadores escolhidos por meio de indicação do diretor, no contexto da prática, o Programa da Unisinos tem um processo de escolha do coordenador

\footnotetext{
49 Regulamento do Programa de Pós-Graduação em Educação: Conhecimento e inclusão social. Universidade Federal de Minas Gerais. Belo Horizonte, MG, 2013.

${ }^{50}$ Regulamento do Programa de Pós-Graduação em Educação. Pontifícia Universidade Católica do Rio Grande do Sul. Porto Alegre, RS, 2010.

${ }^{51}$ Regimento Interno do Programa de Pós-Graduação em Educação da Unisinos. Universidade do Vale do Rio dos Sinos, São Leopoldo, RS, 2010.
} 
bastante similar ao dos Programas da Uerj e da UFMG. Na Unisinos, a sucessão do coordenador também é pensada e articulada por pessoas de influência no Programa (Comissão Coordenadora) e aprovada no colegiado para, num segundo momento, o diretor da UAPPG "acolher" a indicação:

Temos feito isso, embora não seja regra, não esteja escrito em lugar nenhum, até mesmo porque a Universidade não valida isso. A gente faz uma comissão [coordenadora] e de preferência uma pessoa dessa comissão permanece na futura. [...]. Então, isso está se desenhando como um jeito muito interessante de preparar lideranças. (Coordenador A - Unisinos).

No caso da PUCRS, a indicação ocorre, na prática, da forma prevista no regulamento. De fato, é o diretor da Faculdade de Educação que escolhe o docente que irá ocupar do cargo e não há menção à participação de outros professores no debate sobre a escolha do nome proposto: "É indicação, convite da direção. O diretor convida alguém para fazer parte, para assumir a coordenação." (Coordenador C - PUCRS).

A forma de provimento do cargo de gestão, de acordo com o que ocorre no contexto da prática, nos permite identificar os Programas da Uerj, da UFMG e da Unisinos como aqueles nos quais os gestores são escolhidos por pessoas de influência no corpo docente e os nomes aprovados pelo colegiado para, finalmente, serem legitimados formalmente pela via da indicação ou da eleição. De outro lado, encontra-se o Programa da PUCRS, no qual a indicação é feita diretamente pelo diretor da Faculdade de Educação, conforme consta em seu regulamento.

\subsection{2.}

\section{Remuneração financeira para o exercício do cargo}

Outro tema que influencia o contexto da gestão é a gratificação financeira recebida para o exercício do cargo de coordenador. Dos quatro programas pesquisados, apenas a Unisinos e a UFMG remuneram os coordenadores desses Programas. O grupo de coordenadores da Unisinos, cuja gratificação para a ocupação do cargo é cerca de $\mathrm{R} \$ 1.200,00^{52}$ (Hum mil e duzentos reais), não mostrou insatisfação em relação a este aspecto.

\footnotetext{
${ }^{52}$ Valor mencionado por um dos entrevistados em abril de 2013
} 
Na UFMG, entretanto, os coordenadores se mostraram insatisfeitos porque consideram que a gratificação não é condizente com a carga de responsabilidades da função:

Irrisória! [...] $\mathrm{R} \$ 700,00$, com os descontos a gente recebe $\mathrm{R} \$ 500,00$. (Coordenador B - UFMG).

Era muito pouco! [entrevistadora: Já me falaram que eram $\mathrm{R} \$ 700,00$ e líquido $\mathrm{R} \$ 500,00]$ Era menos que isso [...] Ninguém é coordenador por essa gratificação. (Coordenador D - UFMG).

Os programas que não gratificam seus coordenadores, por sua vez, lhes oferecem uma diminuição da carga horária em sala de aula, de modo a liberar tempo para as atividades de gestão. Nas entrevistas, os docentes que ocupam essa função sem receber uma gratificação também se mostraram insatisfeitos:

Só mais trabalho, só mais trabalho [...] Não tem gratificação. Eu reclamei muito disso, dentro da Universidade [...] mas não é nem pelo valor, é pelo simbólico. (Coordenador C - PUCRS).

Aqui nenhuma [gratificação]. A Uerj, diferentemente de outras Universidades, não gratifica. Ela nos libera de 4 horas por semana para coordenar o Programa. Esse Programa, com 202 alunos, 30 professores, 3 funcionários [...] Você viu porque não tem eleição? (Coordenador A - Uerj).

Ao longo do processo de amadurecimento da pós-graduação brasileira, houve uma complexificação das atividades, com maior sujeição da academia a orientações do governo federal, por meio de ações indutivas e do processo de avaliação dos programas pela Capes. Também aumentaram as exigências em relação à produtividade acadêmica e à necessidade de os programas submeterem projetos a diferentes editais para obtenção de recursos. Com isso, a gestão dos programas de pós-graduação tem se tornado uma atividade cada vez mais complexa, pois envolve cuidar de diferentes aspectos, tais como: a avaliação; a produção intelectual do programa; a internacionalização da pesquisa; a formação dos alunos; a busca de recursos para pesquisas; além das questões administrativas do Programa e da Universidade. Para quem assume essas atribuições, a sobrecarga de trabalho acaba interferindo negativamente nas atividades de pesquisa:

[...] eu tinha que dar aula na graduação porque o Departamento me obriga, não me libera. Então, eu dava aula na graduação, coordenava o Programa e orientava. Eu não conseguia fazer, não aceitei convite para ir a evento, não dei "uma" palestra, eu não escrevi nada, eu descuidei da minha pesquisa [...]. (Coordenador B - UFMG). 
O problema é o seguinte: quando ele é coordenador, não deixa de ser professor pesquisador. Então, ele tem que gerir os seus próprios projetos, continuar reunindo o grupo, pedindo dinheiro, prestando contas, fazendo relatórios, escrevendo artigo, participando de reunião, entendeu? (Coordenador D - Uerj).

A ocupação do cargo de coordenador de programa acaba prejudicando a pesquisa e a produção intelectual do docente, porque demanda uma significativa parcela de tempo. O quadro se completa com as resistências existentes para a ocupação do cargo reveladas pelas entrevistas.

Porque é assim: todo mundo foge disso [do cargo de coordenador]! Mas foge meeesmo! (Coordenador D - Uerj).

Por saber que essa é uma bagagem bem grande, ninguém se candidata. (Coordenador A - Unisinos).

Antes o [coordenador anterior] falava: "Agora você vai ser coordenadora" e eu falava não, não! (Coordenador B - UFMG).

Diante disso, somos levados a questionar sobre quais motivos levam os professores a aceitarem a coordenação de um programa. A despeito das dificuldades relatadas, é possível perceber que o cargo é assumido seja por pressão do grupo, que coloca constrangimentos para o candidato negar a indicação, seja por compromisso com a instituição, ou ainda, pela oportunidade de encarar novos desafios.

Então, como isso nunca foi meu sonho, o que me levou a aceitar participar da coordenação é que eu me constituí também como um professor/pesquisador no Programa durante 10 anos. Eu achei que chegou o momento de retribuir com minha cota, não é? (Coordenador A - Uerj)

Vejamos, vamos incluir 3 anos nisso [na tarefa de ser coordenador], mas pode ficar tranquila que por uns 10 anos ninguém mais vai te pedir para ser coordenadora. [...] É, só por 3 anos! Sempre lembrando isso! (Coordenador D - Uerj).

Então, na verdade, foi um "presente" que eu ganhei por ter ficado um ano fazendo pós-doutorado. (Coordenador D - UFMG).

Eu acho que ninguém é assim, pelo menos não na [Universidade] federal. Ninguém "pega" [o cargo de coordenador], isso [gratificação] não pesa nada. "Pega" porque é o desafio, desafio pessoal [...]. (Coordenador C - UFMG).

Neste ponto, as entrevistas com os coordenadores apontam para o fato de a importância do valor simbólico do cargo se sobrepor a seu valor material. Ao perguntarmos aos entrevistados sobre o lado positivo de serem coordenadores de 
programa, a maior parte deles mencionou questões relacionadas à visibilidade, ao poder e à oportunidade de articulação política.

Você passa a ser uma pessoa que interage com outras e ganha visibilidade. Você conhece a área. Passa a conhecer o mundo acadêmico, a conhecer uma série de coisas, [...] O meu poder para mudar alguma coisa nisso é mínimo, mínimo, mínimo. Mas, no mínimo, você está ali e, quem sabe, depois de uma ação, aquilo pode surtir algum efeito. (Coordenador B - Uerj).

O que é a parte que seria, digamos assim, a "moeda de troca" é que [...] enfim, você tem, você ganha, uma circulação pelas instâncias que fazem a política. Você está mais perto de um circuito de tomada de decisão que faz a política da pós-graduação no Brasil. (Coordenador A - PUCRS).

Ainda em relação à questão da gratificação financeira, circulam informações de que a Capes estaria adiantada no processo de propor a instituição da Bolsa de Coordenação de Programas de Pós-Graduação stricto sensu, que ainda não teria sido regulamentada por razões de ordem jurídica. De acordo com informações da Capes, somente após essa etapa, e havendo disponibilidade orçamentária e financeira do órgão, é que a referida bolsa poderia ser implantada.

Essa iniciativa é, no entanto, a um só tempo, objeto de adesão e de crítica. Particularmente, entendemos essa bolsa como um reconhecimento, por parte da Capes, de que os professores que ocupam esse cargo precisam ser remunerados pela carga extra de trabalho que recebem e concordamos com essa decisão.

Um dos dirigentes de entidades representativas da pós-graduação entrevistados, entretanto, vê a gratificação como uma forma de enfraquecer as instâncias coletivas, pela via do fortalecimento da relação direta e individualizada entre a Capes e cada um dos coordenadores de curso. Mais especificamente, segundo seu depoimento:

Ela é uma bolsa que tenta cooptar o coordenador do programa para a política da Capes e que vai ao sentido de enfraquecer as mediações coletivas. Porque à medida que a Capes se relaciona diretamente com esse coordenador, dá a ele uma bolsa, é como se ele "virasse um funcionário" da Capes. Ou ele segue a cartilha da Capes ou ele pode perder, vamos dizer assim, o cunho salarial que ele passa a ter. E isso vai enfraquecendo as instancias mais coletivas. Pode enfraquecer, ainda não está acontecendo [...]. (Dirigente Anped).

O mesmo dirigente afirma que é comum a Anped receber, por parte da Capes, "recados" de que o órgão não conversa com as associações.

Isso não está formalizado, não está oficializado, mas eles não querem hoje reconhecer essas associações, eles querem conversar diretamente 
com o coordenador de cada programa de área. Fica claro que isso é uma estratégia política de fragmentação. (Dirigente Anped).

Essa análise do dirigente da Associação acaba sendo reforçada pelo depoimento de um coordenador de Área, também entrevistado pela pesquisa:

\begin{abstract}
A Anped não [é ouvida pela Capes]. É uma colocação tão clara da Capes (pelo menos eu acho que não do MEC) contra a Anped, que eu diria que, numa reunião de coordenadores, eu não posso dizer que está [presente] o presidente da Anped, ou o coordenador do Forpred na sala. (CA-Edu A).
\end{abstract}

Nesse caso, a Bolsa de Coordenação é lida como mais uma das estratégias da Capes de enfraquecimento das instancias coletivas no campo educacional.

\title{
5.2.3.
}

\section{Preparação para atuar na função}

Chegamos ao terceiro ponto das dimensões contextuais relativas à ocupação do cargo de coordenador de programa: a preparação desses docentes para atuar na função. Diante dos desafios administrativos, políticos e acadêmicos assumidos pelos coordenadores de programas, torna-se relevante investigar se houve algum tipo de preparação para as tarefas pertinentes ao cargo.

Durante as entrevistas, foi possível constatar que nenhum dos profissionais recebeu formação específica formal prévia para atuar como coordenador de programa. A formação para o cargo, em todos os casos, aconteceu "na prática", antes e/ou depois de os coordenadores assumirem a função.

Dois docentes da PUCRS externaram contrariedade pela falta de uma preparação prévia para a tarefa, tida como tão complexa. O fato de esses coordenadores terem sido indicados pelo diretor, talvez sem um tempo para que a ideia fosse amadurecida dentro do grupo, como acontece no caso dos outros programas, pode ter contribuído para a sensação de "falta de preparação":

\footnotetext{
Alguma formação? Nenhuma preparação, nenhuma. [...] Ah, é terrível, as minhas contas são sempre um desastre, a minha casa é [desorganizada]. Aí tem que montar, manter o Programa funcionando: é um caos. É bem difícil. (Coordenador C - PUCRS).

Olha, isso é incrível, é abrupto, é uma passagem totalmente abrupta. Você chega aqui, você é uma professora dentro da sua salinha, fazendo suas coisinhas, tudo direitinho e, de um dia para o outro, você chega aqui e tem que sair decidindo, entendendo das portarias, sei lá.
} 
É um monte de informação, e você tem que saber. (Coordenador A PUCRS).

Apesar das falas contundentes, esses mesmos dois coordenadores, em outros momentos de suas entrevistas, mencionaram o fato de terem participado da comissão coordenadora do Programa, antes de assumirem o cargo, e o significado positivo desta experiência para sua gestão, como no trecho que segue:

Em geral, eu era da comissão coordenadora, em geral o coordenador sai da comissão coordenadora. Então, enquanto comissão coordenadora, você vai já se aproximando desse cotidiano da gestão. (Coordenador A - PUCRS).

A maioria dos coordenadores dos outros programas consideram as experiências prévias que tiveram na pós-graduação como subsídios à formação para enfrentar os desafios da coordenação. Inferimos que, nos demais programas o nome do coordenador é "construído" por um grupo mais influente e, geralmente, a pessoa indicada já vem participando em outros âmbitos da gestão, tais como comissões, colegiado, ou mesmo no apoio à própria coordenação, a passagem para a função de coordenador se dá de uma forma mais sequencial e paulatina. Os coordenadores, inclusive, elogiam essas formas de preparação prévia:

\footnotetext{
No meu caso, eu tive outras coisas [...]. Não tive nada específico, nenhum curso, mas já era a alguns anos do colegiado. Então, isso me dava um conhecimento dessa dinâmica. Eu tinha sido vice coordenador do Programa. [...] Eu acho que é o melhor modo, e todos os programas deviam fazer isso. (Coordenador D - UFMG).

A gente sempre trabalhou com o princípio de sustentabilidade do Programa, que é preparar uma gestão do início ao fim. Isso eu levo hoje como um ato de fé, porque essa é a questão, preparar uma pessoa para a gestão. (Coordenador B - Unisinos).
}

O responsável pelo último depoimento explicou, também, que a pessoa que hoje está na coordenação fazia parte da comissão coordenadora anterior e que isso a aperfeiçoou para exercer essa tarefa. Da mesma forma, quem pertence à atual comissão está mais preparado para exercer as próximas coordenações.

De acordo com Cunha (2006), a formação do professor universitário tem sido entendida, por força da tradição e da legislação, como atinente quase que exclusivamente aos saberes relacionados ao conteúdo de ensino. Essa formação do professor especialista, no nível de pós-graduação stricto sensu, versa exclusivamente sobre o conhecimento legitimado academicamente no seu campo científico de atuação. Entretanto, autores como Teixeira et al. (2012) ressaltam ser 
de fundamental importância a participação dos docentes também nas atividades de gestão e de planejamento das Universidades, para que a autonomia dessas instituições possa ser construída e preservada.

Existe, ainda, um entendimento legal de que as atividades de gestão de ensino estão entre as funções do professor das Universidades públicas, já que a LDB 9394/96, em seu artigo 56, prevê que 70\% dos assentos em órgãos colegiados deliberativos e comissões de instituições públicas de ensino superior devem ser ocupados por docentes.

A despeito disso, a questão da formação ou preparação do docente para atuar na gestão da pós-graduação não tem tido presença na literatura do campo educacional.

Em síntese, com relação à formação prévia dos coordenadores, na maioria dos programas pesquisados, os coordenadores entendem que a experiência anterior em diferentes âmbitos da gestão dos programas, como comissões, colegiados etc. os preparou adequadamente para exercer o cargo de coordenador.

\subsection{4.}

\section{Apoio técnico-administrativo}

Independentemente das estratégias de formação para o cargo, reveladas nos depoimentos pelos coordenadores, há também registro de críticas ao fato de as Universidades não terem um corpo técnico especializado para dar suporte ao trabalho de gestão, o que faz com que os coordenadores sejam levados a assumir tarefas administrativas que estariam fora de sua alçada.

Um dos coordenadores da Uerj aponta que o problema não é a falta de formação prévia, mas sim, a falta de apoio técnico especializado:

\footnotetext{
É, não tive [preparação para atuar na função]. Nem acho que é necessário. [...] Para as coisas que são administrativas, falta é funcionário. Se "você" tivesse um excelente chefe de gabinete que passasse [a gestão] de um coordenador para o outro [...], o coordenador cuidaria somente dessa parte da política. (Coordenador B - Uerj).
}

A maior parte dos entrevistados mencionou a falta de um corpo técnico especializado em questões administrativas da pós-graduação como um ponto nevrálgico dos programas. Para eles, em geral as equipes técnicas não conseguem 
ir além das questões mais rotineiras, como o atendimento ao público, a inscrição e matrícula de alunos, o sistemas de gerenciamento acadêmico, a certificação e diplomação, o preenchimento de formulários de procedimentos internos (bancas, dispensa de disciplinas, ajuda de custo etc.).

Os coordenadores, no entanto, almejam poder contar com equipes técnicas que consigam atender de forma mais autônoma as demandas administrativas mais complexas da pós-graduação, tais como o gerenciamento das informações quantitativas do Coleta Capes $^{53}$, o gerenciamento financeiro de recursos, a prestação de contas de projetos acadêmicos segundo os trâmites do Tribunal de Contas da União (TCU), a coordenação de informações entre diferentes sistemas, envolvendo a Universidade, a Capes e os sites dos programas. Eles desejam poder contar com profissionais especialistas nessas funções da gestão administrativa:

\begin{abstract}
A Universidade tinha que profissionalizar sua gestão. Criar cargos de gestão que fossem cargos de nível superior com mestrado e doutorado, por exemplo. "Você" poderia ter na Faculdade de Educação três cargos de gestor com doutorado, para a pessoa ganhar bem! Um cargo que iria ajudar na administração da pósgraduação, [...] essa pessoa não vai ter poder de decisão, porque poder de decisão é dos coordenadores e professores, mas ela teria autonomia, teria "ciência" para fazer essa questão. (Coordenador E - UFMG).
\end{abstract}

A secretaria [acadêmica] é um corpo técnico que dá conta daquilo que é "secretaria" mesmo, enfim: ofício, aquilo que é mais rotina, preenchimento de relatório e tal. Mas ainda nos falta alguém que dê conta mais dessa coisa da gestão estratégica. (Coordenador C PUCRS).

As Universidades não têm estrutura de secretaria qualificada em nível de programa de pós-graduação, então o coordenador acaba fazendo uma série de coisas administrativas. (Coordenador C Uerj).

Foi possível observar que parte dos coordenadores acaba encontrando formas alternativas de suprir parte das carências relativas a tarefas administrativas mais especializadas com estratégias como concessão de bolsas para alunos auxiliarem em tarefas administrativas, ou contratação de pessoas especializadas com verba de pesquisa. Entretanto, essas iniciativas não são as mais adequadas, são transitórias e não resolvem o problema.

O problema mais crítico é que a falta de agentes com formação para apoiar a coordenação dos programas na realização de atividades administrativas mais

\footnotetext{
${ }^{53}$ Ver nota 29.
} 
complexas, que são exigidas pela condução atual dos cursos stricto sensu, acaba prejudicando a atuação dos coordenadores não apenas no âmbito da gestão, mas também no âmbito estritamente acadêmico, notadamente em relação à pesquisa $\mathrm{e}$ à produção intelectual.

\section{3.}

\section{Estratégias adotadas pelos coordenadores de programas}

O que é possível depreender das entrevistas é que os coordenadores reelaboram as orientações estabelecidas no nível macro de forma diferenciada, de acordo com suas interpretações subjetivas e com suas experiências coletivas. Em decorrência disso, escolhem estratégias diferenciadas para a execução da Política de Pós-Graduação e para sua "tradução" em ações no contexto da prática.

Ao analisarmos os depoimentos dos coordenadores dos quatro programas pesquisados foi possível perceber que esses programas adotaram estratégias similares em relação a três dimensões, a saber: à gestão coletiva dos programas, ao corpo docente e ao corpo discente. Ao mesmo tempo, em cada caso, também foi possível perceber as características e estratégias específicas de cada uma dessas experiências.

\subsection{1.}

\section{Estratégias de gestão coletiva dos programas}

Estamos chamando de "gestão coletiva dos programas" um conjunto de características que faz com que as decisões mais importantes da gestão sejam compartilhadas por uma equipe de professores. Os dezesseis coordenadores entrevistados demonstraram se sentirem apoiados no trabalho por um grupo de professores que dividem com eles a responsabilidade da gestão do programa. $\mathrm{O}$ tema emergiu como "categoria nativa" da fala dos entrevistados, que destacaram a grande diferença que fez o apoio recebido quando da ocupação dos seus cargos.

A Política de Pós-Graduação, no nível mais macro dos textos da Capes, prevê alguns elementos de gestão coletiva para a pós-graduação, como é o caso do 
Regulamento do Proex ${ }^{54}$ (CAPES, 2006). Segundo o documento, é necessário que os programas instituam uma Comissão de Gestão - CG/Proex, com a atribuição de aprovar o Plano de Metas Acadêmicas e de servir de instancia de acompanhamento e julgamento de questões relativas às verbas recebidas.

Entretanto, nos documentos da Capes há também uma ênfase na centralização da gestão dos programas na figura do coordenador, uma vez que fica a seu cargo a maior parte das responsabilidades administrativas, financeiras e jurídicas do programa. Vejamos alguns trechos redigidos na perspectiva da centralização das responsabilidades na figura do coordenador presentes nesse Regulamento (CAPES, 2006):

Art. 5 São atribuições da Coordenação do Programa de PósGraduação: I - instituir o processo de escolha, composição e o funcionamento da CG/PROEX, dando ciência a Capes; II - zelar pela execução do programa [...].

Art. $6^{\circ}$, inciso IX: “[...] o coordenador deverá apresentar a Capes, quando de sua substituição ou eventual saída, uma prestação de contas de sua gestão no prazo de 30 (trinta) dias a contar da data de sua saída." (CAPES, 2006, grifo nosso).

Art. 11 "A inobservância por parte do coordenador do programa de pós-graduação às normas operacionais, acarretará a imediata interrupção dos repasses, e a restituição à Capes dos recursos aplicados irregularmente. (CAPES, 2006, grifo nosso).

O fato é que, embora a Capes coloque a necessidade de uma Comissão de Gestão dos recursos do Proex, as atribuições executivas e as responsabilidades jurídicas ficam a cargo do coordenador, mediante compromisso de auxílio financeiro firmado com a Capes.

Essa questão foi criticada por um dos coordenadores entrevistados:

[...] é complicado! Porque é uma minúcia, um detalhamento, uma responsabilidade [...] E aí tem as coisas do cotidiano, como: "ah, um professor perdeu o cheque. Como é que faz?", "um aluno foi assaltado com o cheque do Proex e aí, como é que faz?". Tem que ir ao banco, sustar. Enfim, é uma complicação! [...] centraliza no coordenador, que não tem como descentralizar. (Coordenador A - Uerj).

A despeito disso, foi interessante perceber que, no contexto da prática, em todas as experiências essa centralização é minimizada pelas estratégias de gestão coletiva acionadas pelos gestores, que estão baseadas na existência de um tripé mais ou menos comum: (a) um núcleo docente forte de tomada de decisão; (b) um

\footnotetext{
${ }^{54}$ Portaria $^{\text {o }} 34$, de 30 de maio de 2006.
} 
colegiado atuante; e (c) comissões permanentes e temporárias para apoio às diferentes tarefas dos programas.

Visando um entendimento mais contextualizado de cada programa, vamos apresentar, separadamente, como esses pontos aparecem associados em cada uma das experiências pesquisadas.

\section{Gestão Coletiva no Programa da Unisinos}

O Programa da Unisinos possui formalmente um coordenador indicado pelo diretor, com funções executivas. No contexto da prática, no entanto, o Programa opera com um arranjo diferente: compõe uma comissão coordenadora com três professores que representam cada uma das linhas de pesquisa. Assim, embora o coordenador tenha a responsabilidade formal pelo andamento da gestão, esta é dividida com essa comissão e um dos membros é designado como vice coordenador do Programa:

Então, apesar de a Universidade ter a orientação de ter só um coordenador, nós nunca obedecemos esse critério. E a gente sempre insistiu, especialmente com a gestão do [nome do coordenador anterior], em uma comissão de três pessoas. Por que três? Porque com duas só tem um vice. E então, ficariam duas pessoas, uma chamando a outra, para decidir alguma coisa. E com três, não! Três já dá aquela ideia de que tem um grupo que representa um pouco as linhas de pesquisa. (Coordenador A - Unisinos).

No período da minha gestão tínhamos uma comissão coordenadora que apoiava muito, também, formada por mim e pelas professoras [nomes das professoras]. Nós fazíamos reuniões semanais de coordenação, todas com apontamentos em ata, para discutirmos as agendas do Programa, avaliar o andamento das comissões etc. Era uma parceria muito boa. (Coordenador C - Unisinos).

A segunda característica do Programa da Unisinos é a existência do colegiado, com atribuições consultivas, constituído pelos professores dos quadros de docentes permanentes e de colaboradores e pelos representantes discentes: Os relatos mostram que o colegiado é atuante e está inserido em uma cultura de planejamento das atividades, por meio de reuniões:

Então é isso: tinha uma visão do colegiado do Programa que passou a se reunir sistematicamente uma vez por mês; uma coordenação coletiva não centralizada. Era um trabalho coletivo e, a partir de então, na verdade, já existiam três pessoas para passar a atuar como coordenação coletiva, mesmo tendo um coordenador executivo. E ainda, as comissões, as linhas de pesquisa, as atas com decisões coletivas registradas e socializadas. (Coordenador B - Unisinos). 
Há duas reuniões gerais (uma em fevereiro, outra em julho), em um local fora da instituição, nas quais o grupo (coordenação, colegiado e duas secretárias do Programa) fica "imerso" por dois dias pensando as principais definições para o ano. Além dessas reuniões maiores, há uma sistemática de reuniões toda segunda-feira, da seguinte forma: a primeira segunda-feira do mês é reservada às reuniões do colegiado, a segunda é destinada a reuniões das linhas de pesquisa; a terceira é das comissões de apoio; e a quarta é mais ou menos livre, para a coordenação chamar uma pesquisa ou fazer alguma reunião extra (de comissões ou colegiado). (Coordenador A - Unisinos).

Por fim, a força das comissões na atuação em diferentes "frentes de trabalho" é a terceira característica da gestão coletiva do Programa da Unisinos. As comissões são instituídas para tratar de assuntos específicos. No período em que realizamos nossa pesquisa de campo, as comissões eram as seguintes: "Seleção e Acompanhamento de Bolsas"; "Produção de Conhecimento"; "Currículo e Internacionalização"; "Proex"; "Congresso Interno"; e "Seleção Discente”. As quatro primeiras são permanentes e as duas últimas temporárias. As comissões funcionam e estruturam o trabalho, que é discutido no colegiado, concretizando, dessa forma, o trabalho coletivo.

\section{Gestão Coletiva no Programa da PUCRS}

No Programa da PUCRS, o coordenador é assessorado por uma comissão coordenadora, composta da seguinte forma: diretor da Faculdade de Educação (membro nato); coordenador do Programa (membro nato); os docentes representantes de cada uma das três linhas de pesquisa e representante discente. Os coordenadores do Programa ressaltam a importância dessa comissão para a realização do trabalho de gestão, pois podem dividir com ela as tarefas da coordenação e as decisões que precisam ser tomadas: "Claro [que a comissão coordenadora é um bom suporte]! Dividimos a decisão. Nós dividimos as tarefas, eu acho fundamental." (Coordenador B - PUCRS).

Além disso, o Programa conta com um Conselho de Pós-Graduação, um fórum formado por todos os professores do Programa e a representação discente, à qual, um dos entrevistados, se refere como colegiado ${ }^{55}$ : “Tem colegiado, é bem bacana. Se esse colegiado contribui? Contribui muito. Ali é que a gente

\footnotetext{
${ }^{55}$ Na PUCRS, no entanto, a expressão "colegiado" refere-se a um fórum diretivo da Faculdade de Educação responsável apenas por assuntos ligados à graduação.
} 
[argumenta] e faz o balão de ensaio das grandes discussões." (Coordenador C PUCRS).

Por fim, no Programa da PUCRS, o tripé da gestão coletiva se completa com as comissões de apoio instituídas para tratar de questões específicas. Foram citadas durante as entrevistas algumas delas, como a "Comissão de Bolsas e Produtividade Discente"; a "Comissão Científica"; a "Comissão de Análise de Currículo"; e a "Comissão de Processo Seletivo". O Coordenador - C da PUCRS explica como funcionam:

\begin{abstract}
A gente tem a prerrogativa de criar comissões específicas para ações específicas. Então, gerenciamento das bolsas e o acompanhamento da produtividade dos discentes, por exemplo, são feitos por uma comissão. A comissão científica é uma comissão [que trata] do processo de saber se vai encaminhar ou não para o comitê de ética, supervisionar o protocolo e tal. O processo seletivo é feito por uma comissão; análise de currículo, aproveitamento de disciplinas, enfim, tudo é feito por uma comissão. Então, a gente constitui pequenas comissões ad doc para atender demandas que são específicas também.
\end{abstract}

Na experiência do Programa da PUCRS, diferentemente do que ocorre na Unisinos, é possível observar que o contexto da prática reflete o que está previsto nos textos institucionais, tanto no que diz respeito à indicação do coordenador, como na composição das instâncias coletivas e na sua própria atuação, o que faz com que se trate de instâncias reconhecidas institucionalmente.

Um ponto que nos chamou a atenção no caso da PUCRS é, diferentemente dos demais programas, o poder que detém o diretor da Faculdade de Educação junto ao Programa de Pós-Graduação. Não apenas é o diretor quem escolhe o coordenador do Programa, ao que parece, sem participação docente na "construção" do nome, como também é ele também quem indica a composição da Comissão Coordenadora, da qual é membro nato. Além disso, como o diretor faz parte do corpo docente do Programa, também é membro do Conselho de PósGraduação. Ou seja, o diretor participa de todas as instancias de decisão da pósgraduação. O reconhecimento do amplo poder do diretor aparece na seguinte fala:

Aqui na PUC, como em muitas Universidades, acho que até talvez na pública, a Unidade Administrativa não é a pós-graduação, a Unidade Acadêmica Administrativa é a Faculdade de Educação. Então o diretor da Faculdade de Educação está em uma posição de decisão mais importante do que o Coordenador da Pós-Graduação. Ele é quem tem o poder de indicar o Coordenador da Pós-Graduação. (Coordenador A - PUCRS). 
No entanto, é necessário ressaltar que a experiência de gestão coletiva é avaliada positivamente pelos coordenadores do Programa da PUCRS, que consideram haver um efeito positivo decorrente do apoio das diferentes instancias (comissão coordenadora, conselho de pós-graduação, comissões específicas) ao trabalho de gestão, o que nos permite considerar que esta experiência também tem a gestão coletiva como uma das suas características.

\section{Gestão Coletiva no Programa da UFMG}

O Programa da UFMG possui diferentes instancias de apoio ao trabalho do coordenador, a saber: um vice coordenador, um colegiado, duas comissões permanentes de apoio e uma assembleia. Diferentemente do caso das instituições particulares, não possui uma Comissão Coordenadora. O coordenador conta com a ajuda direta de um vice-coordenador eleito entre os membros do colegiado por maioria absoluta. Segundo o relato dos coordenadores entrevistados, a figura do vice-coordenador é importante, porque é alguém com quem é possível dividir diretamente as tarefas cotidianas da coordenação:

\footnotetext{
Para o coordenador, o vice-coordenador é fundamental. O vicecoordenador é uma pessoa com quem você divide o tempo todo [...]. Por exemplo, na [gestão] da [nome de coordenador anterior], eu fui coordenador adjunto, mas eu "peguei" a coordenação sete vezes [...]. (Coordenador E - UFMG).
}

O Programa possui um colegiado atuante, com funções deliberativas, composto pelo coordenador geral, que o preside; pelo vice-coordenador; pelos nove coordenadores das linhas de pesquisa; pelo presidente da comissão de acompanhamento da avaliação docente; pelo presidente da comissão de acompanhamento discente; e por dois representantes discentes de mestrado e doutorado. Segundo os entrevistados, as reuniões são quinzenais, funcionam de fato e dão "vida" à gestão coletiva do Programa:

Então, o colegiado é a vida. "Você" tem uma gestão colegiada mesmo, porque "você" tem a colaboração mesmo dos nove coordenadores de linha, sem a qual seria muito difícil administrar um programa desse tamanho. (Coordenador B - UFMG).

O colegiado passou a se organizar, por exemplo, por linhas, representação de linhas [...] e essa representação de linha acabou tendo um papel muito importante nessa discussão. Então, o colegiado tem funcionado como um espaço de discussão do Programa. Ele 
aliado a essas comissões [...], acho que foi fundamental. (Coordenador D - UFMG).

Compõem o colegiado os presidentes das duas comissões de apoio. Conforme a fala dos entrevistados, essas comissões têm um peso institucional muito forte, especialmente a Comissão de Acompanhamento da Avaliação Docente. Ela é composta sempre pelos ex-coordenadores do Programa e é bastante citada, em todas as entrevistas, como um núcleo que tem uma grande influência na vida do Programa. Um dos coordenadores resume o papel cotidiano dessa comissão:

\begin{abstract}
A presença dos ex-coordenadores é muito forte! Não são todos, mas é como se a gente fosse criando um conjunto de pessoas que compreende melhor o funcionamento e que está atento para os problemas fundamentais, que tocam nos critérios de avaliação e nas normas do Programa (Capes, CNPq e outras agências de fomento), que acompanham essas tendências mais gerais, que estão sempre "de olho" para onde o Programa está indo, que rumos estão tomando e, ao mesmo tempo, estão "de olho" no funcionamento interno para não deixar nenhum [...] desvio. (Coordenador A - UFMG).
\end{abstract}

Essa comissão, por ser composta por membros seniores do Programa, passa, na visão dos entrevistados, segurança para quem ocupa o cargo de coordenador, pois ajuda na tomada de decisão sobre questões importantes, respaldando-as. Isso faz com que os coordenadores tenham um sentimento de segurança e de ser parte de uma gestão compartilhada:

A coordenadora se sente segura porque qualquer decisão que tem de tomar, relativa aos professores, ela passa ali. Qualquer gestão que considerar complicada, ela tem o apoio de gente que teve experiência na coordenação e, então, eu acho que ajuda muito [...]. Não significa que não ficam inúmeras atividades para o coordenador; óbvio [que sim]! Mas ela tem esse apoio político que é fundamental. (Coordenador B - UFMG).

Outro aspecto relativo à gestão coletiva do Programa da UFMG é que, por uma decisão do colegiado, as linhas têm autonomia financeira. Cada linha tem um coordenador, que representa o grupo no colegiado e coordena, dentro de sua linha, as discussões acadêmicas e financeiras, o que contribui para a descentralização de responsabilidades.

As linhas passaram a ter, de certa forma, uma gestão financeira também do Programa, ou seja, as linhas começaram a ter dinheiro. [...] O dinheiro de custeio era, e ainda é assim, em boa parte, distribuído para as linhas. Isso também implica mais as linhas no gasto do dinheiro com os alunos, com essa discussão. Acho que descentraliza, 
descentra da coordenação, e mesmo do colegiado, discussões sobre, por exemplo, política de gastos. (Coordenador D - UFMG).

Por fim, este Programa é o único entre os pesquisados que adota a assembleia como fórum de discussão. A assembleia é constituída pelos professores em exercício e por representantes dos funcionários e alunos. Ela não tem poder deliberativo, mas na prática, todas as decisões tomadas em assembleia são respaldadas pelo colegiado.

\begin{abstract}
No nosso regulamento ela [a assembleia] não tem poder deliberativo porque o poder deliberativo é do colegiado. Mas ela tem esse poder. Eu não me lembro de nenhuma vez que o colegiado tenha contrariado a assembleia. Essa é uma tradição do Programa [...] desde que eu era aluno. (Coordenador D - UFMG).
\end{abstract}

Durante a pesquisa, foi possível perceber que o Programa da UFMG faz esforços para manter atuantes os canais de participação da comunidade acadêmica. Esse compromisso democrático pode decorrer da existência histórica no Programa de professores que marcaram forte presença no debate sobre a democratização da educação nos anos 80, como Neidson Rodrigues, Carlos Jamil Cury, Miguel Arroyo e Magda Soares, para citar apenas alguns nomes.

Vale lembrar que, como em todo espaço democrático, os conflitos estão presentes também nessa experiência, sendo encarados de forma positiva, como é possível perceber nos depoimentos a seguir:

\footnotetext{
Esse grupo não é coeso, ele tem divergências fundamentais, mas existe uma preocupação com a coisa pública, com os rumos da coisa pública, como se fosse um barco que a gente quer preservar. (Coordenador A - UFMG).
}

Houve concordância e houve muita discordância em certas coisas, e isso, então, é um momento de debate do qual decorrem (ou não) certas definições programáticas e pragmáticas. Então, a assembleia tem sido esse espaço legal de discussão. (Coordenador D - UFMG).

\title{
Gestão Coletiva do Programa da Uerj
}

A gestão coletiva do Programa da Uerj está apoiada em três elementos institucionais: o vice-coordenador, o colegiado e as comissões de apoio. O elemento que destaca esta experiência das demais, pelo que pudemos apurar nas entrevistas, é o processo de descentralização da gestão. Enquanto nas experiências anteriores a coordenação exerce a mediação na maioria dos fóruns de debate, na Uerj o coordenador muitas vezes é dispensado de participar de processos 
importantes, ficando essa responsabilidade, de fato, para outras instancias, como a vice coordenação, o colegiado, e/ou, especialmente, as comissões de apoio.

O vice-coordenador, segundo os entrevistados, não apenas compartilha a responsabilidade da gestão com o coordenador e o substitui quando se faz necessário, mas exerce funções diferenciadas, dentro da coordenação, relacionadas com a dimensão acadêmica do curso. $\mathrm{O}$ fato de o vice-coordenador assumir funções específicas está previsto no regulamento do Programa. Esse agente tem um campo de atuação independente, o que desonera o coordenador de certas atribuições.

Tem uma comissão que a gente chama de tática administrativa, que é o vice-coordenador com mais um professor que cuida da parte acadêmica do curso. (Coordenador C - Uerj).

E o coordenador adjunto trabalha também. Aqui você tem as duas funções. A gente sempre dividiu, divide as tarefas. Então, não é só contribuir, substituir por ter tido faltas e impedimentos, não. Ele tem tarefas específicas. (Coordenador C - Uerj).

O Colegiado do Programa de Educação da Uerj é composto pelo coordenador do Programa, o vice-coordenador, os representantes de linha de pesquisa e os demais docentes do Programa, que representam $70 \%$ do fórum. Os outros $30 \%$ são compostos por representantes de alunos e funcionários. É um colegiado grande, atualmente com quase cinquenta pessoas. Segundo os relatos, o órgão é atuante, toma decisões relativas ao encaminhamento do Programa e é dele que saem as comissões de apoio para a realização de tarefas específicas.

Normas de como compor bancas, normas de como receber "pós-doc", normas de tudo isso são definidas no colegiado. [...] Eu fiquei como coordenadora, não me preocupava com seleção de alunos porque a gente organiza o edital, o colegiado organiza a comissão de seleção e aí a comissão de seleção cuida. Coordenador aqui "só entra" se tiver algum problema que precisa mediar, algo que raramente acontece. (Coordenador B - Uerj).

Então, eu acho que, com essa divisão do trabalho, a gente tem um colegiado atuante, que toma as decisões. Embora, é claro, que sempre fique um pouco mais de peso, o coordenador não fica sozinho para o processo de Coleta Capes. (Coordenador C - Uerj).

O ponto mais enfatizado pelos entrevistados da Uerj é o trabalho desenvolvido pelas comissões. Entre as comissões citadas ao longo das entrevistas, estão a Comissão de Apoio Acadêmico, a Comissão de Bolsas, a 
Comissão de Avaliação Anual Coleta Capes, a Comissão de Recursos Financeiros, além de Comissões de Seleção, de caráter temporário.

Por meio dos relatos, é possível perceber que essas comissões são bastante autônomas e se responsabilizam pelo cumprimento das tarefas:

\begin{abstract}
Eu acho que o que mudou foi essa redefinição do Programa na última década. A reformulação do ponto de vista não só do projeto acadêmico, mas também da sua estrutura, com as comissões descentralizadas, que de fato criam um grau de responsabilidade coletiva muito maior no âmbito de estruturas [...] Nós temos um grupo de quatro comissões permanentes que atuam no Programa, e temos as comissões temporárias, que são, por exemplo, as comissões de seleção [...]. E as comissões são responsáveis pela elaboração do edital até a divulgação do resultado final. A coordenação apenas acompanha, coordena e apoia. Enfim, esse é um trabalho totalmente descentralizado. (Coordenador A - Uerj).

Nós sempre tivemos uma Comissão de Coleta Capes. Eu, por exemplo, não sei nada de Coleta. [...] Então, isso que eu acho que é uma diferença em relação aos outros Programas, nos quais os coordenadores ficam enlouquecidos. Aqui você tem uma divisão. Nós temos uma comissão de bolsas, que é muito ativa, que o coordenador nem faz parte, por exemplo. (Coordenador $\mathrm{C}$ - Uerj).
\end{abstract}

Ao observarmos as principais características da experiência da Uerj, o ponto que chama mais atenção é que o Programa também adota um modelo de gestão compartilhada, que é bem mais descentralizado do que o dos outros programas estudados. No caso da Uerj, são várias as instancias que colaboram com o coordenador e assumem a responsabilidade por uma série de tarefas específicas que abrangem todo o processo de gestão, do planejamento à sua implantação.

Em síntese, não há centralização da gestão na figura do coordenador de programa em nenhuma das quatro experiências. No entanto, embora a gestão seja mais coletiva, em todas as experiências, o coordenador ainda precisa assumir um significativo número de tarefas e de responsabilidades.

\title{
5.3.2.
}

\section{Estratégias adotadas junto ao corpo docente}

Os coordenadores, por serem atores que estão em posição mediadora entre a política proposta no nível macro e os agentes que as colocam em prática no nível micro, se situam em um espaço de ação desafiador, na medida em que precisam incentivar o corpo docente a atingir as metas estabelecidas, muito 
embora nem sempre estejam em plena concordância com o que foi estabelecido pela política nacional e pelo âmbito institucional local. Soma-se a isso, o fato de que eles também atuam como docentes e sentem o peso da multiplicidade de tarefas atribuídas aos professores.

Nesta seção abordaremos os principais desafios enfrentados pelos coordenadores dos programas pesquisados em seu trabalho de mediação da política junto ao corpo docente, colocando em destaque duas questões comuns às quatro experiências ao longo da década pesquisada: mudanças no perfil do quadro docente; e a implantação de uma política efetiva de credenciamento de docentes.

\section{Mudanças no perfil do quadro docente}

No final dos anos 1990 e início dos 2000, a pós-graduação se situava em um contexto de mudanças políticas e econômicas, que incidiam no quadro docente das Universidades públicas e privadas. Enquanto as Instituições de Ensino Superior (IES) públicas careciam de recursos para dar andamento às suas atividades, as privadas foram beneficiadas com o credenciamento acadêmico e o crédito financeiro.

De acordo com Cunha (2004), durante os dois governos de FHC, as IES federais foram submetidas a um arrocho ainda mais forte, uma vez que tiveram restringidos os recursos para custeio e investimento, enquanto as instituições privadas foram brindadas com novas vantagens.

Essa situação acabou provocando um processo de aposentadoria acelerado de muitos profissionais das instituições públicas e em um "êxodo" para instituições privadas. O Coordenador C - Unisinos resume essa situação:

\footnotetext{
Também foi um momento interessante da política econômica brasileira, no qual muitos professores deixaram as IES federais e passaram para as IES particulares. [...] Estavam se aposentando e, muito jovens ainda, em plena capacidade de trabalho. Foi uma conjuntura que nos favoreceu.
}

Paralelamente, estava acontecendo a mudança no paradigma da Avaliação da Capes, ocorrida no final do biênio 1996-1997, que fez com que os programas repensassem suas atividades e prioridades, e o papel a ser desempenhado por seus docentes. Essa conjuntura, somada a outros fatores particulares de cada uma das instituições, provocou alterações importantes no quadro docente dos quatro 
programas pesquisados. Ao longo das entrevistas, essas mudanças foram citadas como um dos elementos que provocou o início de um processo de renovação em cada um dos programas.

Os coordenadores da UFMG mencionaram que houve uma renovação do quadro docente que impactou muito o Programa. Este Programa sempre foi reconhecido por possuir um quadro docente de renome, que marcou presença nas discussões sobre a democratização do ensino no país. Com a aposentadoria de parte desses docentes, houve uma renovação do quadro que veio acompanhada de uma mudança de perfil. Os professores que ingressaram, alguns ex-alunos do próprio Programa, tinham uma perspectiva de atuação mais alinhada aos critérios de avaliação estabelecidos pela Capes, de inserção em pesquisa, de publicação e de internacionalização. Esse contexto favoreceu o início das mudanças realizadas ao longo da década de 2000.

\begin{abstract}
Essa mudança institucional, é claro, ela vêm junto com uma mudança mais cultural, de uma maior adesão do corpo docente do Programa a esses novos modos de organizar, por exemplo, a questão do grupo: fortalecer a ideia do grupo, dos alunos entrarem com projeto vinculado ao projeto do professor [...] um subentendimento maior do corpo docente aos modos de consagração acadêmicos da Área. Não é só a questão da pesquisa, que eu acho que isso era forte nos professores do Programa, mas também a ideia, por exemplo, de que você vai publicar em revista, que você vai escolher e administrar mais isso. [...] Um perfil de parte do corpo docente que entrou acabou também contribuindo para que essa inserção internacional se desse de forma não apenas mais volumosa (que a gente passa a ter mais convênio, mais produção conjunta e uma serie de coisas), mas veio ao encontro do critério que a Capes colocava de internacionalização. [...] Não que antes não tivesse, mas acho que antes o corpo docente não operava muito com essa lógica. Essa renovação acabou retomando tradições antigas, o Programa com muito vínculo internacional dos seus antigos professores, mas numa nova dinâmica. Acho que isso também contribuiu. (Coordenador D - UFMG).
\end{abstract}

No Programa da Uerj, além das questões de fundo comuns ao cenário nacional, somou-se o fato de parte do corpo docente ter saído para formar um novo Programa de Pós-Graduação, o de Políticas Públicas e Formação Humana (PPFH). A partir daí, houve a entrada de novos professores, e uma mudança na concepção acadêmica do Programa, que se refletiu na reestruturação das linhas de pesquisa:

Houve a saída de um grupo de professores que foram criar o PPFH e isso criou condições para que essas reformas que estavam em curso pudessem se desenvolver num outro ambiente, e deu certo. [PPFH é] Programa de Políticas Públicas e Formação Humana, que é um 
Programa para onde foram pessoas do Proped $^{56}$, como Raquel Villardi, Lilia do Vale, Pablo Gentili, Gaudêncio Frigotto. [...] Nós éramos em torno de vinte professores, no início dos anos 2000, e passamos para trinta. Portanto, houve uma saída de gente e a entrada de uma turma nova, que renovou em torno de $1 / 3$ do corpo docente. Então, houve uma reformulação do ponto de vista de um projeto do Programa, acompanhado de uma reformulação das linhas e recomposição do corpo docente. [...] Isso teve efeitos do ponto de vista da entrada do professor no Programa, que não é uma entrada, assim "de qualquer modo". [...]. Portanto, esse sistema de credenciamento também incorpora um pouco o docente já muito afinado com essas temáticas de avaliação e de credenciamento e de uma formatação a que os Programas são submetidos hoje no país (Coordenador A - Uerj).

Os programas das instituições privadas também se favoreceram do novo contexto. O Programa da Unisinos se beneficiou do fato de a instituição ter investido recursos financeiros para a consolidação da pesquisa na Universidade, assim como da entrada de professores recém-saídos de instituições públicas e com experiência acadêmica e de pesquisa. Esses professores tiveram um papel tutorial em relação aos demais professores do Programa, como mostra o depoimento a seguir.

Na época, não tinha tão claro, e lembro que foi a [professora advinda de Universidade pública] que trouxe isso com muito esforço: o lugar dos grupos de pesquisa no Programa, que sistematizava a participação dos estudantes na pesquisa do professor. Esse entendimento foi "chave". Ela argumentava, e continua argumentando, que a participação dos estudantes no campo, e os professores com menos experiência com professores com maiores referencias, gerava uma produção cientifica muito maior. [...] Cresceu muito a produção docente/discente a partir do momento que os grupos de pesquisa passam a ter um lugar orgânico no Programa, [...] Mas, aí, tem que pensar também no contexto da Unisinos. A Unisinos, mais ou menos no mesmo período, reforça sua identidade como Universidade de pesquisa, e isso também influencia. (Coordenador B - Unisinos).

O Programa da PUCRS, por sua vez, se beneficiou da entrada de novos professores que, inclusive, assumiram o cargo de coordenação, convivendo, assim, com uma parte importante do grupo mais antigo do Programa. Há certas tensões nesta composição, principalmente em relação ao alinhamento dos docentes mais antigos com o que a Capes espera em termos de produtividade de um programa de pós-graduação. A forma de equacionamento desta questão tem sido a renovação paulatina do quadro docente, com processo seletivo direcionado a um novo perfil de professor, com mais produção científica.

\footnotetext{
${ }^{56}$ Programa de Pós-Graduação em Educação da Uerj.
} 
Qual a grande dificuldade? [...] A aderência ou adesão, digamos assim, do corpo docente a esse novo modelo de pós-graduação. Era um corpo docente com professores com bastante mais idade, de outra época, de outra lógica, poucos professores jovens. Então, pouca adesão a esse perfil de produtividade, de Qualis, revistas e tal. Então, era uma coisa mais tranquila, naquele ritmo um pouco mais lento. Uma ação da coordenação foi justamente pensar quais eram as questões estratégicas que a gente tinha que fazer para que os professores aderissem. (Coordenador C - PUCRS).

Uma boa parte dos professores é bem antiga. Nosso Programa é um Programa com professores mais idosos e que estão aqui há muito tempo, tanto que tem sido uma política nossa nas contratações recentes buscar diminuir a média de idade do Programa. A gente tem procurado professores mais jovens e que, ao mesmo tempo, sejam seniores em termos de produtividade científica, o que é um perfil bastante difícil. (Coordenador A - PUCRS).

Por fim, é importante mencionar que, no caso das IES públicas, ao contrário das Universidades privadas estudadas, as alterações no corpo docente ao longo da década resultaram na ampliação do quadro docente ${ }^{57}$. Os programas pesquisados que funcionam em Universidades particulares, ao contrário, chegaram à última avaliação trienal com uma média um pouco menor de docentes do que no início da década ${ }^{58}$, como será visto em detalhe no capítulo 7.

\section{$\underline{\text { Política efetiva de Credenciamento de Docentes }}$}

Chegamos ao que consideramos um dos pontos mais emblemáticos das estratégias de gestão adotadas no intuito de melhorar o desempenho acadêmico dos programas: a implantação de uma política efetiva de credenciamento de professores. Quando incluímos no título o adjetivo "efetiva" para qualificar essa política, é porque a Capes passou a solicitar regras claras para credenciamento de docentes permanentes e colaboradores de todos os programas da Área da Educação ${ }^{59}$. Entretanto, é preciso destacar que essa política muitas vezes só existe no âmbito formal, havendo um recredenciamento automático dos professores dos programas.

\footnotetext{
${ }^{57}$ A média de docentes permanentes na Uerj e UFMG era de 19 e 33 no Triênio 2004 e de, respectivamente, 24 e 59 no Triênio 2010.

${ }^{58}$ A média de docentes permanentes na PUCRS e Unisinos era de 15 no Triênio 2004 e de, respectivamente, 13 e 14 no Triênio 2010.

${ }_{59}$ Ver Comunicado no ${ }^{\circ}$. 003/2012 - Área de Educação - Orientação para novos APCNs - 2012 (CAPES, 2012).
} 
Os quatro programas da pesquisa, no entanto, adotaram uma política efetiva de credenciamento de docentes, que inclui também processos de recredenciamento e descredenciamento; e este é um ponto de convergência importante entre as experiências.

No caso das Universidades públicas, os professores da pós-graduação, em geral, já faziam parte do quadro de docentes da instituição, com atuação no âmbito da graduação.

$\mathrm{Na}$ Uerj, a passagem desses professores para a pós-graduação ocorre com base nos seguintes critérios: o professor precisa participar durante dois anos de uma linha de pesquisa do Programa, ter produção acadêmica condizente com um programa de pós-graduação e ter projeto de pesquisa vinculado a uma agencia de fomento.

A UFMG, por sua vez, especificou os critérios de credenciamento em portaria específica $^{60}$, que determina que haja uma solicitação formal à coordenação do Programa, acompanhada de proposta de ingresso apresentada pela linha de pesquisa com base em projeto de trabalho do professor; de comprovação de seis publicações qualificadas nos últimos três anos (pelo menos dois produtos devem ser artigos Qualis A ou livros ou capítulos de livro avaliados como L4 ou L3); e, por fim, participação em atividades docentes de pós-graduação e/ou nas atividades da linha de pesquisa.

O estabelecimento de critérios fez com que a entrada de novos docentes nos programas passasse a ocorrer de maneira mais formalizada e mediada pelo compromisso com a produção acadêmica:

Quanto ao ingresso, a gente observa a norma, mas a gente também observa para além da norma o desempenho do professor de modo que a gente possa ver se ele cumpre a norma por acaso ou se ele está numa tendência de engajamento, produção e inserção na pós-graduação, na lógica da pós-graduação, na lógica da pesquisa. (Coordenador A UFMG).

Já a entrada de professores novos para o quadro docente dos programas das instituições privadas ocorre por meio de processo seletivo direcionado para a pós-graduação. Assim, a partir das mudanças relatadas, tanto a Unisinos quanto a PUCRS passaram a ser mais criteriosas em relação ao perfil dos professores que passam a fazer parte dos seus quadros.

${ }^{60}$ Resolução no 03/2011 - Modifica a Resolução 02/2010 que regulamenta o ingresso e a permanência de professores no Programa de Pós-Graduação em Educação da FaE/UFMG. 
Então, houve uma renovação grande do professorado. Quando tu contratas um bom professor, tu não tens o que ensinar para ele. [...] Eles são contratados, não para a graduação, eles trabalham na graduação porque aqui todo mundo trabalha na graduação e na pós, mas não tem uma carga muito grande. Mas esses foram contratados primeiro para a pós. (Coordenador B - PUCRS).

Além de uma entrada mais criteriosa, os programas passaram a fazer um acompanhamento sistemático da publicação dos docentes, realizado pelo coordenador ou por uma comissão específica para esse fim. Além disso, foram estabelecidos critérios de permanência no programa (recredenciamento) que, na maior parte dos casos, foram discutidos e definidos com aprovação do colegiado.

No caso da UFMG, o recredenciamento dos docentes ocorre a cada três anos e a "Comissão de Acompanhamento e Avaliação Docente" fica atenta ao longo do período, acompanha o processo e conversando com os professores que estão com baixa produção, com vistas à sua recuperação dentro do triênio objeto de avaliação.

\begin{abstract}
Um professor que entra no Programa hoje sabe que vai ser recredenciado daqui a três anos. [...] No inicio deste ano, nós fizemos a avaliação de todos os professores cujo credenciamento vence ano que vem. [...] A gente olha como é que está a situação dele. Se estiver tranquila, a gente nem conversa com ele. Se está tranquila em termos de produção, se ele teve em 2 anos uma produção suficiente para o triênio [...] Mas se ele não tem a produção, a comissão o chama para uma conversa no sentido de alertá-lo ou de perguntar. Porque, às vezes, tem professor que acumula, ele vai falar: "olha, estou com vários artigos em não sei quantas revistas, mas é que ainda não tive resposta" ou "já tenho aprovação, mas ainda não foi publicado", ou "tenho isso, isso e isso". E tem aqueles professores que falam "realmente estou encrencado, eu não tenho nada"!
\end{abstract}

Nos demais programas, um trabalho similar é realizado pelas coordenações, que procuram orientar o professor no sentido de apontar eventuais faltas em termos de publicação, equilibrar a produção e direcionar melhor a publicação dos artigos. Nesses casos, a cobrança parece ser mais sistemática e mais preocupada com os critérios específicos estabelecidos pela Capes:

A fala aqui da coordenação, minha particularmente, mas na época da [coordenadora anterior] também, não é só uma questão de dizer que tem que publicar. Publicar, as pessoas já publicam. A questão é dizer "Olha gente, os critérios são esses. Olha só, tem que se preocupar em publicar em artigo". Tem que explicar como é a avaliação, explicar que tem que ser no mínimo B2, explicar que tem que orientar os processos [...] divulgar: "Olha, saiu um edital na Faperj ${ }^{61}$, saiu um edital no CNPq, saiu um edital na Capes, olha gente”. E, mais ainda,

\footnotetext{
${ }^{61}$ Fundação de Amparo à Pesquisa do Estado do Rio de Janeiro.
} 
colaboração conjunta. A gente [percebe]: “Opa, fulano está com produção, o outro está com um problema, como é que a gente pode fazer?", [...] marcar com uma solidariedade também. Isso também sempre foi desenvolvido. [...] No primeiro ano do triênio, fazia um levantamento da produção de todo mundo, informava para cada professor: "olha, sua parte de produção está nisso, é legal que você esteja num patamar a mais", "Como é que a gente pode ajudar a melhorar isso?" (Coordenador B - Uerj).

Olha, o que o [coordenador anterior] fez e que de alguma maneira a gente segue fazendo é, digamos, um monitoramento da produção do professor e, em alguns momentos, de reuniões gerais ou mesmo reuniões com os professores, uma devolução do quadro de produção no sentido de fazer um balanço. Eu acho que tem um processo quase formativo. Claro não é, a gente tem o cuidado de não expor os professores, de nunca fazer essas devoluções com os nomes dos professores [...] Mas o que a gente faz é mostrar perfis gerais da equipe. Então, por exemplo, muitas produções em anais de congresso, isso não é interessante, não é pontuado na Capes. (Coordenador A PUCRS).

No caso da Unisinos, inclusive, houve o relato de um caso específico que causou constrangimento na equipe.

E esse [monitoramento] interno é muito mais rigoroso que o da Capes. Ao ponto de um dia, numa reunião, nós estávamos lá no núcleo nosso, do colegiado, e tinha a nossa chefia (que agora não é mais da chefia) e ela expôs os nossos nomes e dizia: "Fulano aqui, está faltando isso." E aí nós nos sentimos muito mal. (Coordenador A - Unisinos).

Em caso de falta de produção, três dos programas analisados (PUCRS, Uerj e UFMG) mencionaram que há um processo de descredenciamento paulatino. Em linhas gerais, isso significa que, em caso de baixa produtividade, o professor fica proibido de oferecer vagas de orientação no processo seletivo, ou seja, fica impedido de ter novos orientandos naquele ano, mas continua no Programa. Caso não recupere a produção, ele passa de permanente a colaborador. Se ainda assim, no próximo ano em que ele for avaliado, continuar com rendimento insuficiente, ele é descredenciado.

Nas entrevistas dos coordenadores da Unisinos esse tipo situação não foi mencionada.

No caso da UFMG, os entrevistados mencionaram que esse processo não é irreversível e que houve só um caso efetivo de descredenciamento:

Mas o que não significa que ele não pode voltar a qualquer momento. Normalmente, professor nesse período ele concentra na produção e volta. Então, é muito raro a gente ter um professor que foi definitivamente desligado. Só tivemos um só nessa história toda. (Coordenador E - UFMG). 
No caso da Uerj, nenhum processo de descredenciamento chegou a ocorrer, de fato:

\begin{abstract}
Houve a gente passar o professor para colaborador? Sim. Retirar do Programa? Não. Mas por quê? Porque a nossa política era: eu chamava na sala e conversava, e pedia e conversava. Ah! E também tem um critério assim: a gente estabelece um patamar que a gente não descredencia, a gente simplesmente coloca aquele professor sem alunos na seleção seguinte. Esse é o nosso critério. Chegar a descredenciar, se for necessário, mas a gente não chegou nisso. (Coordenador B - Uerj).
\end{abstract}

Nas Universidades privadas a questão do descredenciamento tem mais impacto na vida do programa e dos docentes, pois implica demissão. As consequências desse descredenciamento, portanto, são mais profundas para os profissionais que trabalham nessas Universidades, o que é considerado uma condição desigual no interior da classe docente:

\begin{abstract}
É uma polêmica que a gente sempre coloca: descredenciar um professor numa Universidade federal, ele vai continuar fazendo extensão, ele vai continuar dando aula, sei lá [...]. Descredenciar um professor na Universidade privada é aproximar a "sentença de morte" dessa pessoa, ela vai ser demitida. Então isso é injusto quando se pensa numa lógica nacional ou geral de credenciamento e produtividade. (Coordenador C - PUCRS).
\end{abstract}

E dentro de uma Instituição privada, o que é descredenciar? É demitir. Então a instituição não tem aquela coisa de "Ah, não [...] Vamos botar ele para lá [em outra função]". Não. Foi demitida. Então foi muito duro, embora todo mundo tenha concordado que essa era a realidade, não tinha como. Mas a pessoa ficou muito magoada e saiu bem dentro daquele esquema, assim, "sem olhar para trás". (Coordenador A Unisinos).

Os impactos desta questão sobre as subjetividades dos profissionais foram mencionados em todos os programas. Os próprios agentes parecem entender e concordar com as regras definidas, defendendo-as com entusiasmo em diferentes momentos de suas entrevistas. No entanto, é também claro que há um conflito ético bastante forte, na medida em que esses mesmos profissionais reconhecem a sobrecarga que essa cultura acadêmica gera, e o estresse que causa em seus colegas e neles próprios:

Mas eu acho que do ponto de vista mais profundo [o excesso de cobranças] é a questão que, de longe, é o maior dos nossos problemas. Inclusive levando a um adoecimento muito grande e inédito do corpo docente. Então, é uma coisa muito impactante, muito pesada e que, acho que pior ainda, esse problema só tem aumentado, ele não tem diminuído. (Coordenador D - UFMG). 
Eu digo sempre, essa cena me vem sempre, porque nós temos [nota] 6, nós conseguimos manter o 6, mas continuamos apanhando! Isso é lógica jesuíta, a lógica da culpa o tempo inteiro. Não "tá bom que chega!" E eu, então, como alguém que se atenta à Teologia, que fiz doutorado em Teologia, [me pergunto]: fazemos realmente jus a esse papel? Por que a gente se integra a essa lógica? (Coordenador A Unisinos).

Capes começou a mudar um pouco os critérios e a gente começou a mexer muito nessa questão da produção individual e, até hoje, é um estresse. Um pouco de cobrança faz parte do estresse do professor de pós-graduação. Agora, o que eu estou falando para você é que não adianta, é a regra do jogo. É a regra do jogo. E nós fizemos assim [...] Nós começamos a fazer uma política até meio antipática, nós resolvemos que os professores que não tinham produção [...] nós baixamos de categoria para professor colaborador [...]. (Coordenador C-Uerj).

Descredenciá-lo do Programa significa que ele vai perder horas de produtividade, vai perder horas de pesquisa, vai perder essas horas todas. Eventualmente, ele não vai ter tanta coisa para fazer na graduação, então, é possível que esse cara acabe demitido. É uma evidência cruel, é um modelo muito cruel, por isso que ele é dolorido. (Coordenador C - PUCRS).

Nota-se, todavia, que os coordenadores não ficaram passivos diante dessas questões, e que lançaram mão de estratégias para oportunizar uma melhora na quantidade e na qualidade das publicações docentes e para minimizar eventuais problemas emocionais que decorrem dessas exigências.

Os coordenadores reconhecem as dificuldades dos professores em relação à realização de seu trabalho e às exigências a que são submetidos. Além da sobrecarga de trabalho, a publicação em periódicos qualificados é outra das dificuldades reconhecida claramente pelos coordenadores. A maior parte dos entrevistados mencionou que os veículos bem qualificados são poucos e que a concorrência na Área da Educação está cada vez maior. Diante disso, alguns entrevistados advertem que cabe ao coordenador de programa ter bom senso, no sentido de não pressionar demais a equipe:

[...] além disso, eu acho que o gestor de um programa de pósgraduação, no momento que a gente está vivendo, ele também tem que ter um pouco de bom senso porque não dá para a gente também [...] Só pensar nisso [em publicação]! (Coordenador A - PUCRS).

Nessa mesma perspectiva, os gestores referem-se a ações realizadas pela coordenação do programa, no sentido de ir além da sanção na direção da ajuda aos professores com vista à melhora da sua produção. Entre essas ações, destacam-se 
as informações sobre os veículos qualificados para publicação e sobre editais específicos aos quais os professores podem concorrer na busca de recursos:

Muito da informação, muito dos fomentos, muito dos incentivos [...] para enviar projetos, entendeu? Porque tu pensas assim [...] Eu conheço assim, alguns programas lá no interior do Rio Grande do Sul, quando é que eles vão descobrir se o [...] ou o CNPq ou a Capes ou o Inep ${ }^{62}$ tá dando bolsa, [...] tem editais. Então, isso é função de coordenador, entendeu? $\mathrm{Na}$ medida em que ele sabe [...] o edital do Inep do Livro Didático, isso faz com que o professor pesquise o livro didático. Então fazer essa "ponte" que eu acho coisa de coordenador. (Coordenador B - PUCRS).

\subsection{3.}

\section{Estratégias adotadas junto ao corpo discente}

Ao lado da produção intelectual docente, o fator de mais impacto na avaliação da pós-graduação é a produção intelectual discente e o prazo de defesa das teses e dissertações. Uma das principais alterações estabelecidas com a mudança de paradigma da avaliação foi o maior rigor com o prazo de titulação de mestrandos e doutorandos. Atualmente, a Área da Educação determina como prazo máximo 30 meses para o mestrado e 48 meses para o doutorado. Na prática, entretanto, a maior parte dos programas utiliza como prazo máximo 24 meses para mestrado e 48 para doutorado, que corresponde ao tempo de vigência das bolsas.

Além disso, é valorizada a produção discente, especialmente quando realizada em conjunto com docentes do programa. Os programas analisados tomaram medidas visando ao cumprimento dessas exigências por parte dos alunos.

Assim como ocorreu em relação aos docentes com o processo de credenciamento, os programas passaram a ser mais criteriosos com os discentes selecionados para os cursos, especialmente em relação ao "perfil acadêmico" pala via de uma maior valorização da participação discente em pesquisa.

Embora a seleção de alunos com base nos projetos de pesquisa dos docentes seja um expediente comum nas Áreas das Ciências Exatas e Naturais, e embora ainda não seja consensual na Área da Educação, os programas analisados passaram a adotar essa modalidade em seus processos seletivos, tendo no vínculo entre projeto do candidato e pesquisa do professor, um dos principais critérios do processo de seleção.

\footnotetext{
${ }^{62}$ Instituto Nacional de Estudos e Pesquisas Educacionais Anísio Teixeira.
} 
Nos Programas da Unisinos e da Uerj, a aceitação dessa modalidade parece ser mais hegemônica, estando sua implantação consolidada. No caso da Universidade estadual, o aluno é selecionado diretamente para um dos projetos de pesquisa dos docentes:

A seleção aqui é sempre para os projetos. Então, não tem uma seleção para o Programa, nem para a linha [...] [as vagas são] vinculadas aos projetos. Por exemplo, o professor "x", vai abrir uma vaga para o mestrado. Então, a gente vai divulgar assim e os interessados naquela vaga, naquele projeto, naquele tipo de discussão, farão a inscrição para aquela vaga [...]. (Coordenador $\mathrm{A}-\mathrm{Uerj}$ ).

Embora nos Programas da UFMG e da PUCRS haja um encaminhamento nesse sentido, as falas dos coordenadores remetem para um processo ainda em fase de desenvolvimento:

[...] fortalecer a ideia do grupo, dos alunos entrarem com projeto, dos alunos entrarem com projeto dentro do projeto já vinculado ao projeto do professor, que é uma mudança que eu diria que não se completou até hoje. Enfim, e nem sei se algum dia vai chegar para todos. Muita gente ainda discorda disso que a gente quer. (Coordenador D UFMG)

A gente começa nesse momento a exigir deles, a cobrar deles, um pouco mais de envolvimento nas pesquisas dos professores [...] Um professor aceitava um orientando não necessariamente alinhando ele aos seus projetos, mas sim ao seu grande campo de conhecimento. Então, com isso, acontecia que muitos dos estudantes, dos mestrandos e doutorandos, faziam os seus trabalhos de forma independente, não vinculando tanto a produção do professor. Então, a gente começou a aproximar, tentar buscar um pouquinho mais de coerência. Pensar na coerência entre a disciplina que o professor dá na graduação, a disciplina que ele dá na pós, a pesquisa que ele faz, o artigo que ele publica e as teses e dissertações que ele orienta. (Coordenador $\mathrm{C}-$ PUCRS).

Em relação às estratégias adotadas para melhoria do desempenho acadêmico dos estudantes, o ponto em comum aos programas, assim como ocorreu em relação aos docentes, é que passou a haver um acompanhamento mais rigoroso por parte da coordenação do desempenho acadêmico dos alunos. No monitoramento do desempenho dos alunos, estão incluídas diferentes questões como o cumprimento do prazo de finalização do curso, o incentivo à publicação, a participação dos alunos em grupo de pesquisa, entre outras.

Nos depoimentos, os coordenadores das Universidades públicas mencionaram o problema da defesa fora do prazo com mais ênfase. De fato, no capítulo 7, veremos que as médias de titulação, especialmente de mestrado, são mais altas na Uerj e na UFMG. Nossa suposição é que, nas Universidades 
privadas, um fator que contribui para que as defesas ocorram dentro do prazo estipulado pela Capes é o fato dos cursos serem pagos, o que faz com que uma prorrogação de prazo também implique em novas despesas para os alunos.

A estratégia adotada pela UFMG para enfrentar o problema da defesa fora do prazo foi a criação de uma Comissão de Acompanhamento Discente, já que o Programa conta com cerca de 400 alunos. Além disso, houve uma política de enrijecimento dos prazos dos pedidos de prorrogação:

Então, quando eu entrei, nós tínhamos um excesso de estudantes que não tinham prazo, não se formavam. E eu fiz uma coisa, e eu acho que muito positiva: estabeleci prazo para todos esses alunos que estavam já "pendurados" para se formar. Então, a turma que entrou, sei lá, em 1999, tem até o dia "tal" para defender. A turma que entrou em 2008 tem até o dia "tal" para defender, e com isso nós realizamos um número espantoso de defesas de mestrado no ano. Então isso já normalizou um pouco o nosso fluxo. (Coordenador E - UFMG).

Porque antes a gente aceitava até doença da mãe, doença do pai, doença da irmã. Hoje, não aceita mais nada disso. Somente se a pessoa comprovar uma doença dela ou maternidade. Essas duas únicas coisas. (Coordenador B - UFMG).

O Programa da Uerj também limitou os prazos e procurou priorizar o trabalho em grupo de pesquisa, através de uma diminuição da carga horária das disciplinas, visando à melhoria da produção acadêmica dos alunos:

Uma das coisas que a gente teve no momento de criação do doutorado foi uma perspectiva de diminuir o número de disciplinas do mestrado; diminuir significativamente, ou melhor, criar um doutorado que tivesse pouquíssimas disciplinas, de tal maneira que o dominante fosse efetivamente o grupo de pesquisa, quer dizer, o seminário do grupo de pesquisa. Então, eu acho que essas coisas todas ajudaram muito e ajudam na questão da produção significativa que a gente tem. (Coordenador D - Uerj).

Por sua vez, o foco dos Programas das Universidades particulares (PUCRS e Unisinos) recai sobre a produção científica dos alunos. Esses Programas recorreram tipicamente a duas estratégias para melhorar o desempenho dos alunos. A primeira delas foi organizar atividades pedagógicas voltadas para essa temática, como as oficinas organizadas pela Unisinos para ensinar os alunos a produzirem artigos científicos e a disciplina criada pela PUCRS com esse intuito:

Então temos a Comissão de Produção de Conhecimento, que inclui a administração e a editoria das revistas. Nessa comissão, por exemplo, a gente faz, a comissão planeja, às vezes, algumas oficinas para os alunos e até para os professores sobre como fazer um artigo cientifico. Então a gente vai atrás, procura alguém que dá uma oficina sobre isso, analisa um pouco a produção do conhecimento do Programa. (Coordenador A - Unisinos). 
Nós temos uma disciplina que se chama estagio de conhecimento [...] Não, ela não é obrigatória, mas nesse semestre, ela tem 28 alunos. Porque os outros professores se deram contam que, quando o aluno chega, ele não sabe, por exemplo, o que foi publicado na Anped sobre o seu tema. [...] Nessa disciplina, o que o aluno faz? Ele consulta dois sites, um da Anped e outro da Capes, que são legitimados. E ele procura o que foi escrito no Brasil, mais recentemente, sobre os temas [...] Depois, ele precisa redigir um artigo, individual ou em dupla, e sempre ele é incentivado a enviar esse artigo para Anped Sul. (Coordenador B - PUCRS).

Além dessas atividades, os programas das Universidades privadas passaram a solicitar, no doutorado, publicação de artigo como requisito parcial para a conclusão do curso:

Nós temos como requisito parcial para obtenção do título de doutorado a exigência de quatro publicações, uma por ano. [...] e elas variam entre publicação em periódico, publicação em trabalhos completos publicados em congressos, resumos, resenhas. A gente admite um conjunto de publicações. (Coordenador A - PUCRS).

Então, eu acho que teve uma exigência maior das próprias comissões, que vai refletir numa discussão de currículo, que a gente fez assim: um crédito obrigatório no doutorado, optativo para o mestrado, e que a gente transformou em dois créditos, referentes à publicação. [...] O aluno tem que submeter, vir à secretaria (secretaria do sistema geral de ensino) e dizer: "Olha, eu tenho aqui uma publicação apresentada na Anped, então eu estou pedindo para validar." [...] Se é Anped, por exemplo, a gente valida dois créditos porque é um congresso de grande destaque na Área. E se for uma revista de B1 para cima são dois créditos também. (Coordenador A - Unisinos).

Como vimos, no contexto da prática, foram enfrentadas questões já previstas nos documentos da Política de Pós-Graduação e na literatura, tais como as críticas ao processo de avaliação; política de credenciamento de docentes; as exigências de cumprimento de prazos de defesa de teses e dissertações. Todavia, o contexto da prática também propiciou a emergência de estratégias próprias aos contextos analisados, como a gestão coletiva dos programas e a preparação prévia e não formalizada do coordenador para as funções de gestão.

Por fim, outros temas emergiram contrariando as expectativas construídas com base na literatura, como a positividade conferida pela maior parte dos entrevistados aos critérios de Avaliação da Capes e à adoção de parâmetros de avaliação oriundos das Ciências Exatas e da Natureza. No próximo capítulo, esses temas serão analisados à luz das contribuições de Stephen Ball e de Pierre Bourdieu. 


\section{6. \\ Considerações sobre o contexto da prática à luz de Pierre Bourdieu e Stephen Ball}

No capítulo anterior, os depoimentos dos coordenadores dos Programas da PUCRS, da Uerj, da UFMG e da Unisinos remetem às relações que se estabelecem entre esses agentes e a atual Política de Pós-Graduação, no contexto da prática.

Os sujeitos investigados manifestaram suas posições sobre a avaliação realizada pela Capes e sobre as principais críticas que comumente lhe são endereçadas.

Também mostramos que elementos relacionados às dimensões contextuais, como a forma de provimento ao cargo, a gratificação financeira, a preparação para a função e o apoio técnico recebido, podem fazer diferença na gestão.

Explicitamos, ainda, as estratégias similares utilizadas nos programas na direção da conquista da "excelência", como a gestão coletiva, a política de credenciamento de docentes, e ainda, a seleção dos discentes em função das pesquisas do programa e o maior rigor com que são julgados os pedidos de prorrogação dos prazos para titulação, principalmente de doutores.

As questões decorrentes desse quadro, e também as formas próprias e comuns aos programas de enfrentá-las, serão analisadas, neste capítulo, à luz das perspectivas teóricas de Stephen Ball e Pierre Bourdieu. Trata-se de questões, interpretações e estratégias acontecidas no contexto da prática dos programas de pós-graduação selecionados, que estão relacionadas à cultura da performatividade, descrita por Ball e ao conceito de campo científico elaborado por Bourdieu.

De acordo com Ball (2005), podemos considerar que, sendo o profissionalismo o resultado de uma relação específica entre o profissional e seu trabalho, baseada na reflexão moral, a performatividade provoca mudanças no profissionalismo dos professores, uma vez que, numa estrutura dominada pela racionalidade técnica, há metas de desempenho e de excelência que pressionam os profissionais, afetando sua subjetividade.

Por sua vez, com base em Bourdieu (1982), podemos considerar que os agentes da pesquisa agem por meio de estratégias diferentes em função de 
diferentes posicionamentos no campo científico. Neste caso, nossa análise dará destaque às estratégias utilizadas pelos docentes coordenadores nas lutas concorrenciais, de acordo com suas funções e posições no campo educacional.

\section{1 .}

\section{Stephen Ball: o contexto da prática e a cultura da performatividade}

Ball e seus colaboradores (BOWE; BALL; GOLD, 1992; BALL,1994) afirmam que os agentes reinterpretam as políticas desenhadas no nível macro, no contexto de influencia e no contexto de produção de texto, traduzindo-as em ação por meio de estratégias diferenciadas em suas arenas de atuação, no nível micro. Mainardes (2006) indica que, no movimento de interpretação ativa das políticas, os pesquisadores precisam relacionar os textos da política à prática, identificando resistências, acomodações, subterfúgios e conformismos nas arenas da atuação.

Nessa perspectiva, identificamos, no contexto da prática dos programas pesquisados, pontos em comum em termos de "acomodações/ adaptações de textos institucionais" e "reinterpretações ativas da política", que serão analisados neste tópico.

Além disso, identificamos outros aspectos que podem ser analisadas à luz do conceito de performatividade (BALL, 2002; 2004; 2005; MOREIRA, 2009). Nesta cultura, há uma tendência a nomear, diferenciar e classificar, e os profissionais tendem a observar regras geradas de forma exógena, que fazem com que a prática profissional se veja constrangida pela necessidade de satisfazer julgamentos rígidos e impostos a partir de fora.

No contexto analisado, foi possível identificar elementos característicos da cultura da performatividade, que serão explicitados e analisados por meio das categorias "cultura avaliativa", "sobrecarga de trabalho", "visibilidade", "ética profissional", "papel da gestão" e "fragmentação de instâncias coletivas".

\section{$\underline{\text { Reinterpretação ativa da política }}$}

A reinterpretação ativa da política foi percebida, especialmente, em relação aos entendimentos que os coordenadores dos programas têm do que seja um Programa de Excelência. Embora estejam cientes da definição que a Capes 
confere a Programas de Excelência como aqueles com alta produção acadêmica em nível internacional, os coordenadores também manifestam seus próprios entendimentos do conceito, valorizando aspectos como a tradição do programa e do corpo docente, o vínculo com movimentos sociais, a internacionalização, solidariedade e apoio a países menos desenvolvidos, a diversidade do corpo docente, o compromisso com a docência, os valores relacionados ao trabalho coletivo, a busca de uma educação de qualidade e, ainda, o trabalho com a comunidade local.

Em um contexto de performatividade, hegemonizado pela racionalidade técnica, com critérios de qualidade e boa prática fechados e totalizantes, como são os critérios determinados na Avaliação da Capes, os sujeitos correm o risco de se tornarem "meros expectadores" de suas práticas. Entretanto, ao explicitarem suas próprias convicções do que seja um Programa de Excelência e, principalmente, ao buscar agir de acordo com elas, esses profissionais conseguem constituir-se como "sujeitos da ação", que realizam uma gestão mais coletiva e apoiada na reflexão moral sobre a prática.

Dessa forma, eles conseguem exercer seu profissionalismo, no sentido definido por Ball (2005), como relação específica entre o profissional e seu trabalho, baseada na reflexão moral.

\section{Acomodações/ adaptações de textos institucionais}

No contexto da prática, foi possível observar acomodações e adaptações dos textos institucionais, por exemplo, em relação às formas de provimento ao cargo de coordenador e em relação à gestão coletiva. As regras especificadas nos regulamentos dos programas (contexto da produção de texto) ganham nuances diferenciadas na arena de atuação dos agentes, sendo retraduzidas de acordo com cada contexto, por meio de acomodações realizadas em função de suas crenças e expectativas.

Nos casos da Uerj, UFMG e Unisinos, especificamente, as acomodações acontecem pela adequação do que está determinado pelos regulamentos dos Programas (eleição, nas IES públicas e indicação do coordenador, na Unisinos) às expectativas de escolha de um novo coordenador articulada por grupos de docentes com maior influencia. As acomodações são feitas pelos atores no sentido 
de adequar os regulamentos dos programas pela via da candidatura única, de modo a garantir a eleição ou indicação da pessoa escolhida pelo grupo de maior influência no Programa.

Na Uerj e na UFMG, normalmente, há um consenso antes da proposição da candidatura, tanto por parte do colegiado, quanto por parte do "escolhido", e um único candidato se apresenta à eleição.

No caso da Unisinos, o grupo se articula, o colegiado aprova e a direção respalda a escolha.

Nesse contexto, as diferenças entre a eleição direta (Uerj), a eleição representativa (UFMG) e a indicação na Unisinos são minimizadas, já que a eleição e a indicação acabam se tornando um evento destinado a formalizar aquilo que já está previamente definido.

Diante disso, é possível inferir que, nesses programas que adéquam o regulamento às suas expectativas, o coordenador acabe tendo uma maior legitimidade e mais apoio do colegiado, que participa da decisão da escolha, como pode ser percebido na seguinte fala:

Aconteceu de os colegas acharem que poderia ser uma boa coordenadora! [...] E, para mim, foi até uma surpresa porque eu sou muito discreta na minha vida acadêmica. Eu fico muito na minha [...]. Eu vi como uma coisa positiva, na medida em que é um reconhecimento dos colegas. (Coordenador A - UFMG).

Em contrapartida, no Programa da PUCRS, no qual o coordenador é escolhido pelo diretor sem uma participação mais ativa do grupo dos professores, é possível supor que os novos coordenadores enfrentem mais resistências. Em uma das falas, foi possível perceber que a proposta do novo coordenador passou por um processo de "negociação" com os colegas:

Minha experiência de coordenação não foi simplesmente plantar ou implantar um modelo. Eu trazia proposições, eu tinha convicções e, assim como os meus colegas abriram mão de algumas crenças em favor das minhas, eu também tive que rever algumas convicções, algumas crenças minhas em favor daquilo que surgia. (Coordenador $\mathrm{C}$ - PUCRS).

O mesmo processo de adaptação dos textos institucionais ocorre em relação à gestão coletiva na Unisinos que, embora não esteja prevista nos regulamentos, ocorre na prática. $\mathrm{O}$ grupo docente lança mão de estratégias específicas com vista à realização do trabalho de forma mais coletiva, por meio de 
uma comissão coordenadora e do trabalho por comissões, e que vão além do que está estabelecido no contexto dos textos institucionais.

É possível perceber que algumas diretrizes estabelecidas pelo próprio Programa parecem estar incorporadas de tal forma no grupo que este não sente necessidade de formalização. Por exemplo, quando perguntado sobre a divisão do trabalho dos componentes da comissão coordenadora em relação ao acompanhamento das comissões de apoio, um dos coordenadores responde que não há nada formalizado, pois: "Como ela [a lógica das comissões] já está tão presente, a gente sabe o que é, não precisa 'inventar mais moda'. De fato, isso já está lá no 'DNA' do Programa.' (Coordenador A - Unisinos).

As acomodações feitas pelos programas aos textos institucionais podem ser consideradas uma característica positiva das equipes, na medida em que nosso país é marcado por uma cultura burocrática na qual as regras escritas, muitas vezes, atrapalham o andamento das atividades. A postura dos grupos é reveladora de certa autonomia dos profissionais diante dos contextos em que estão imersos.

Pudemos notar que esses programas levam em consideração os critérios estabelecidos nos documentos emitidos pela Capes, em especial, os determinados no Documento de Área e nas Fichas de Avaliação dos Programas. Neste caso, foi possível perceber que há mudanças nas práticas de gestão relacionadas a docentes e discentes, respectivamente, por meio de exigências maiores de publicação e de processos mais rigorosos de credenciamento, e processos seletivos de discentes mais sintonizados com a identidade de pesquisa do programa.

As adaptações nos textos da instituição ocorrem no sentido de facilitar a escolha do coordenador (indicação pelo grupo) e o exercício da gestão (gestão coletiva), o que, por sua vez, contribui para o cumprimento dos objetivos determinados nos textos da Capes.

\section{$\underline{\text { Cultura Avaliativa }}$}

Como vimos, a nossa atual Política de Pós-Graduação, por meio da Avaliação da Capes, estabelece uma série de parâmetros para que os programas persigam determinados patamares de produtividade científica docente e discente, assim como o cumprimento de prazos em relação ao fluxo dos alunos nos cursos. 
Para alcançar e se manter no grupo dos Programas de Excelência, os critérios são ainda mais rigorosos e específicos, o que, a partir da chave de leitura fornecida pelo conceito de performatividade, nos permite dizer que os programas de excelência estão expostos a uma maior objetivação, a partir da qual eles são padronizados, qualificados e comparados. De fato, os docentes estão sendo mais cobrados e exigidos, e isto torna previsíveis os conflitos relacionados com o seu desempenho. De acordo com Moreira:

[...] a performatividade desempenha papel crucial no conjunto das políticas educacionais contemporâneas. Contribui para integrar e redimensionar atividades, processos e resultados. Facilita o monitoramento do Estado e propicia sua intromissão nas culturas, práticas e subjetividades das instituições educativas e de seus profissionais. Altera os significados, produz novos perfis e garante o alinhamento. (2009, p. 33-34).

Os coordenadores dos programas analisados se mostraram bem adaptados à cultura avaliativa instituída. Eles aprovam a Avaliação da Capes e atribuem a ela a melhoria da qualidade da pós-graduação brasileira, assim como a legitimação da pesquisa da Área da Educação na comunidade acadêmica.

Eles consideram como aspectos positivos da avaliação o fato de o processo ser feito por pares, de garantir um uso mais racional e adequado do dinheiro público e de incentivar a pesquisa, especialmente em programas de instituições particulares.

Algumas críticas são dirigidas, em especial, à associação feita entre mérito e fomento, que beneficia programas em instituições mais estruturadas e também ao fato das Áreas das Ciências Exatas e Naturais terem mais prestígio, mais poder e auferir um volume maior de recursos.

No entanto, a maior parte dos entrevistados aprova o modelo adotado, rebatendo as críticas que apontam seu carácter homogeneizador ou produtivista e defendendo que a adoção de parâmetros é necessária e positiva e que a exigência em relação ao número de publicação não é tão alta. Também não veem como negativa a adoção de critérios das Ciências Exatas, uma vez que reconhecem que essas áreas são mais consolidadas no campo científico.

A aprovação da avaliação manifestada nos depoimentos se concretiza em ações como a decisão do corpo docente de buscar a "excelência" acadêmica, no maior rigor presente no processo de credenciamento e recredenciamento dos docentes e nas exigências relativas à seleção, produção acadêmica e prazo de 
titulação dos alunos. Essas estratégias estão em sintonia com os parâmetros de produção estabelecidos na Avaliação da Capes e nos remetem, mais concretamente, a aspectos da cultura da performatividade, que enfatiza a valorização de resultados quantitativos e a busca de prestígio e reconhecimento pela comunidade acadêmica.

A busca de uma excelência acadêmica mobilizou os quatro programas no início da década, quando a Avaliação da Capes passou a balizar mais claramente o trabalho na pós-graduação. Esses programas discutiram propostas e puseram em prática ações que contribuíram para a melhoria dos resultados e das notas ao longos das avaliações trienais.

Nas quatro experiências, houve uma seleção mais criteriosa de novos professores (credenciamento) e foram adotados critérios mais rigorosos para a permanência (recredenciamento/descredenciamento) dos docentes nos programas. Neste caso, aspectos e indicadores presentes nos textos da política no nível macro (indicadores definidos para a avaliação trienal da Capes) são replicados e traduzidos em ações no nível micro.

No âmbito interno dos programas, os profissionais são julgados (servem ou não para o programa?), seus indicadores de produtividade são analisados (produziu artigos? quantos? qual o Qualis?) e, em alguns casos, comparados de forma bem explícita (professor tal precisa ter mais artigo Qualis A, por exemplo).

Da mesma forma, um maior rigor é adotado, pelos programas, em relação ao processo seletivo e ao prazo de titulação dos discentes. Há um acompanhamento mais atento por parte da coordenação do desempenho acadêmico dos alunos e são instituídas estratégias visando o aumento da publicação discente, como a exigência de publicação acadêmica como requisito parcial para a conclusão do curso.

Os professores, em função das metas que o programa precisa alcançar, se mostram menos sensíveis a questões pessoais dos alunos, que expressam um enrijecimento dos critérios, face às dificuldades com o cumprimento dos prazos, à escolha dos temas de pesquisa das teses e dissertações ou, ainda, à publicação de artigos. Dessa forma, prazos instituem-se em metas e as metas tornam as relações tornam-se mais performáticas, remetendo-nos ao quadro descrito por Ball:

Tanto as interações quanto as relações de colegas e de professores e alunos são potencialmente retrabalhadas. No que se refere às interações, existem pressões sobre os indivíduos, formalizadas por 
meio de avaliações, revisões anuais e bancos de dados, para que deem sua contribuição à performatividade da unidade. Aí reside uma possibilidade concreta de que as relações sociais autênticas sejam substituídas por relações performativas, em que as pessoas são valorizadas com base exclusivamente na sua produtividade. (2005, p. $556)$.

\section{$\underline{\text { Sobrecarga de Trabalho }}$}

$\mathrm{Na}$ perspectiva da cultura da performatividade, os docentes estão sendo cada vez mais cobrados no sentido de atingir metas em avaliações externas, desempenhar novos papéis e realizar um número maior de atividades, o que acarreta uma sobrecarga de trabalho. De acordo com Ball:

\footnotetext{
Novos papeis e subjectividades são criados conforme os professores são "re-trabalhados" como produtores/ proporcionadores, empreendedores educacionais e gestores e são sujeitos a avaliações/ apreciações regulares, a revisões e comparações do seu desempenho. Novas formas de disciplina são colocadas pela competição, eficiência e produtividade. (2002, p. 7).
}

Podemos perceber referências dos coordenadores à sobrecarga de trabalho gerada por esse contexto quando eles argumentam em favor de uma equipe técnica mais especializada para apoio à gestão da pós-graduação; quando apontam para a multiplicidade de tarefas às quais estão submetidos os professores universitários; e ainda, quando consideraram que o peso da pós-graduação não decorre dos parâmetros de produção científica, mas sim, do excesso de demandas diferenciadas.

De modo geral, os coordenadores enfatizaram que eles e os demais docentes dos programas estão sobrecarregados em virtude da necessidade de realização de muitas atividades burocráticas. De acordo com Ball:

\footnotetext{
No novo mundo das organizações performativas, o poder instituído segundo formas definidas de tempo-espaço (sistemas de produção de fábricas ou escritórios) é agora menos importante. A base de dados, a reunião de avaliação, a revisão anual, a redacção de relatórios e a candidatura a promoções, inspecções e comparação com pares estão em primeiro plano. (2002, p. 9).
}

De fato, os coordenadores mencionam que há uma quantidade cada vez maior de tarefas administrativas, como, por exemplo, prestação de contas e relatórios de projetos, procedimentos para tramites institucionais (formulários para banca, solicitação de serviços), informações solicitadas pela Capes, e, em especial e mais comentado, o preenchimento do aplicativo Coleta de Dados 
Capes. Está presente na fala dos coordenadores o desejo de que a realização das tarefas de gestão, pelos coordenadores e colaboradores, ocorra com maior independência e de forma mais estratégica, o que aponta para a necessidade de contar com funcionários especializados nas funções especificamente burocráticas de gestão.

Além da realização de atividades burocráticas, os docentes acabam se deparando com a necessidade de assumir uma multiplicidade de tarefas inerentes às suas atividades na Universidade, como a docência na graduação e na pósgraduação, a coordenação de grupos de pesquisa, a editoração de revista, a participação em comissões etc., confirmando entendimento de que a sobrecarga de trabalho não advém necessariamente das exigências relativas ao número de publicações qualificadas da Área.

Assim, os docentes são levados a desempenhar novos papéis e a realizar um número sempre crescente de registros e relatórios, o que faz com que precisem aumentar o ritmo de trabalho, intensificando seus esforços para alcançar metas que lhes foram, de certa forma, impostas (MOREIRA, 2009).

\title{
$\underline{\text { Visibilidade }}$
}

Para Ball (2002), no contexto da cultura da performatividade há uma luta por visibilidade, uma vez que os profissionais estão sujeitos à incerteza e à instabilidade e são observados e julgados de diferentes maneiras, exigindo-se deles desempenhos excelentes.

\begin{abstract}
A questão não é a da possível certeza de se ser sempre visto, observado como num "panóptico". A questão é a incerteza e instabilidade de se ser julgado de diferentes maneiras, por diferentes meios, através de diferentes agentes e agências e a exigência de termos de mostrar desempenhos excelentes [...] (Ibid., p.10).
\end{abstract}

Nos depoimentos, foi possível perceber que os programas participam dessa "luta" na medida em que houve decisão do corpo docente, ou ao menos de boa parte dele, de buscar a "excelência" acadêmica, o que levou à introdução de novas estratégias para alcançar esse reconhecimento.

Outro aspecto relacionado à busca de visibilidade é a aceitação do cargo de coordenador de programa. Sem benefícios financeiros correspondentes à sobrecarga de trabalho gerada pela função, e com prejuízos para as atividades de 
docência e de pesquisa, a visibilidade gerada pelo cargo é o que acaba pesando na aceitação do desafio pelos docentes convidados a assumir a coordenação.

Quando explicam os motivos pelos quais aceitaram a proposta e as vantagens que percebem no fato de ser coordenador, o valor simbólico da função fica evidenciado. A maior parte dos entrevistados mencionou, como aspecto motivador para assumir o cargo, questões relacionadas à visibilidade, poder e oportunidade de articulação política gerada pela posição de coordenador de programa.

A visibilidade, no sentido de agir em função do julgamento dos outros, também aparece no sentimento expresso por alguns dos coordenadores, de que “devem algo" à Universidade. Nesses casos, assumir o cargo também está ligado à questão de "retribuir a instituição", ter que "dar a sua cota", para fazer o que é certo, esperado pela instituição, o que está "à altura" das expectativas, o que mostra que os profissionais se preocupam com a forma como estão sendo vistos pelos colegas da instituição.

\section{Ética profissional}

Ball (2005) denuncia que as tecnologias da performatividade e do gerencialismo representam uma busca modernista por "ordem", "transparência" e "classificação". Tais classificações, como as realizadas por meio do Sistema de Avaliação da Capes e do Sistema Qualis, impõem critérios de qualidade fechados e completos que comprometem as possibilidades de reflexão moral dos profissionais, na medida em que os parâmetros estão dados a priori.

Como o profissionalismo é baseado na capacidade de diálogo entre o profissional e seu trabalho, por meio de um "diálogo comunitário e interno", uma estrutura baseada na racionalidade técnica das classificações torna esse exercício sem sentido, já que não existe espaço para o diálogo e a reflexão moral, quando as definições do que é certo, adequado e valoroso já estão dadas. Esse contexto produz impactos no campo da ética e do profissionalismo.

Diante dos elementos presentes no contexto avaliativo atual da pósgraduação, os coordenadores se questionam sobre o ritmo de trabalho que precisam manter para conseguir atingir suas metas. Assim, o tema da ética 
profissional se faz presente na fala de alguns entrevistados, especialmente por se tratar de professores cujo objeto de reflexão é a própria Educação:

\begin{abstract}
Porque as outras áreas, inclusive, estão arranjando modos de sair dessa, vamos dizer "sinuca de bico". Não é a toa que nas outras áreas os alunos de doutorado há muito tempo estão dando aula na graduação, estão assumindo. Têm instituições privadas que põem seus bolsistas de doutorado para dar aula no lugar dos professores. Então, você tem essa saída. A Educação tem uma grande dificuldade com isso, [...] [já que essa situação] reflete o próprio objeto de reflexão da Educação. [...] Nosso investimento em aula, não apenas presente na relação com o aluno, mas no conjunto da aula, é muito grande. Então dar oito aulas, doze aulas, significa dar 20 horas de docência e isso é muito complicado. [...] Por isso, eu acho que a nossa angústia também, de certa forma, não tem solução. Mas acho que aí também entra essa difícil imbricação entre o professor e o pesquisador. São duas sensibilidades muitas vezes concorrentes. São dois tempos concorrentes que a gente tem e que eu acho que é um elemento a mais para complicar. (Coordenador D - UFMG).
\end{abstract}

São muitas tarefas porque, por exemplo, mesmo que a gente diga, "ah, a política de avaliação é falha porque não criou linhas de inserção social". Ok, agora vai dar para o professor fazer trabalho de ponta, com alta qualidade científica, publicar em periódico internacional, e ao mesmo tempo fazer trabalhos aplicados, na escola básica, ir para a favela, ir para a Vila Fátima? [...] Você acha que a mesma pessoa vai conseguir fazer tudo isso? Não vai! Então, o que eu acho que a gente está submetida a um modelo de Universidade ideal. Entendeu? Que ele não é uma medida humana, ele é mais uma perspectiva idealizada. Outro problema desse ideal que eu acho que eu sinto uma culpa imensa, é que ele se traduz de forma que você tem que atingir tudo isso em um perfil de um único professor. Ele tem uma distribuição de trabalho, você tem professor cujo perfil é mais extensão, inserção social, outro que é produção cientifica de alto nível, o outro [...] Eu acho que o problema é que esse modelo deveria ser um modelo para a Universidade, mas poderia haver uma tolerância, uma compreensão de que dentro de um programa, e que você tem perfis diferentes mais adequados, com pouca inserção social, ou para a produção científica; outro para a divulgação científica, e você não precisa cobrar tudo de todos. (Coordenador A - PUCRS).

Segundo Moreira (2009), no contexto da performatividade que influencia a pós-graduação brasileira, o compromisso do docente fica obscurecido pelo esforço para favorecer o alcance de resultados que conduzirão aos conceitos esperados. Nesse regime, os professores são levados a adquirir as informações necessárias a um desempenho "adequado" e é fomentada uma "paixão pela excelência". Isso consome muito da sua energia, reduzindo drasticamente a parcela que precisam pôr em ação para cuidar do seu desenvolvimento profissional.

Nos trechos acima, nossos entrevistados mostram enfrentar dilemas morais e emocionais ao lidarem com essa dimensão no cotidiano dos seus programas. Eles explicitam esses dilemas em falas como "nossa angústia [...] não tem 
solução", "não é uma medida humana", "eu sinto uma culpa imensa", deixando transparecer um sofrimento genuíno, gerado pela multiplicidade de tarefas e objetivos que precisam atingir:

Tal sentimento [incerteza] está sendo experimentado por muitos docentes da pós-graduação brasileira, permanentemente submetidos a avaliações, a pontuações, a revisões e a promoções que tornam sua atuação em um Programa ou o desenrolar de sua carreira de pesquisador uma terrível corrida de obstáculos (MOREIRA 2009, p.33).

\title{
$\underline{\text { O papel da gestão na performatividade }}$
}

Segundo Ball (2004), a gestão desempenha importante papel na cultura da performatividade, sendo um dos instrumentos utilizados ao seu favor:

\begin{abstract}
A performatividade e a gestão também atuam juntas para se livrarem das gentilezas fora de moda da ética profissional. De fato, a reflexão ética torna-se obsoleta num processo de cumprimento de metas, melhoria do desempenho e maximização do orçamento. Valor (financeiro) substitui valores (morais), salvo quando comprovado que esses valores agregam valor. Mas geralmente, a performatividade funciona para empurrar as instituições do setor público à maior convergência com o setor privado (Ibid., p. 1.117).
\end{abstract}

Foi possível observar que os coordenadores trabalham em favor da cultura da performatividade na medida em que estão adaptados à cultura avaliativa e empregam estratégias para melhoria da produção intelectual docente e discente. São os coordenadores ou as comissões designadas pela gestão do programa que cumprem o papel de estabelecer exigências em relação ao corpo discente e docente, e acompanhar o cumprimento das mesmas.

Muitos foram os exemplos nesse sentido: enrijecimento dos critérios de entrada de novos alunos no programa (vinculados à pesquisa), exigência de cumprimento de prazos de titulação (com pouca margem de prorrogação), critérios para credenciamento de novos docentes no programa, avaliação e acompanhamento da produção dos docentes em atuação, e, em casos mais extremos, até mesmo a demissão de professores.

Por outro lato, esses agentes também reconhecem que eles e os demais docentes estão sobrecarregados, e mostram-se atentos às consequências subjetivas dessa situação. Essa atenção é perceptível no cuidado evidenciado por alguns deles na abordagem dos docentes sem produção, por exemplo. Além disso, essa 
atenção aparece também nos questionamentos éticos que alguns deles encetam a sua própria prática profissional.

Parte dos coordenadores, cientes que são os mediadores entre a política e o corpo docente, percebe que, no desempenho de suas funções, pode lançar mão de estratégias para reduzir o impacto desse tipo de problemas. Nessa perspectiva, eles buscam formas de minimizar os transtornos causados pelo contexto da performatividade em que estão inseridos.

Por isso que eu acho também que o coordenador não pode ser ingênuo de entender essas políticas como algo que você pode traduzir imediatamente e cobrando, porque você mata a sua equipe de stress. Ninguém produz nada, fica todo mundo paralisado, adoece, pede demissão, vai fazer outra coisa na vida. As pessoas continuam sendo humanas, o dia continua tendo 24 horas, todo mundo continua tendo uma vida independente do trabalho, o que é justo. Então, assim, a gente tem que traduzir, digamos, esse ideal. Em qualquer programa esse ideal vai se adequar a uma realidade humana, eu acho. (Coordenador A - PUCRS).

Nós temos um mínimo de oito orientandos por cadeira porque nós temos a seguinte situação: se não temos oito orientandos, a gente tem que dar mais aula na graduação. Ter mais aula na graduação significa ter mais 12horas/aula. Então esse é um estrangulamento que eu, como gestora, sempre negocio, professor por professor, no mês de maio e no mês de outubro, para não permitir que ele tenha 12 horas/aula na graduação. Eu tento mostrar as quinhentas mil coisas que ele faz, para justificar que ele não vá para a sala de aula com tantos alunos assim na graduação. Que "pague" [o número insuficiente de orientandos] com uma turma, ou duas, no máximo. Ficaria em 8 horas/aula. O que já é muito porque a media é de 50 alunos por turma. [...] E fica um problema de gestão interna. E a gente como gestora tem que ficar pensando na qualidade do tempo, porque disso depende a vida desse professor. Eu não posso descuidar. Sinto-me muitíssimo responsável para fazer com que ele tenha o mínimo de conforto para fechar todas as outras coisas que ele tem de fazer na pós-graduação. Às vezes é inevitável: quando ele é novo, não pode pegar muitas orientações, é óbvio, ele tem que fechar aí no mínimo 2 anos, [...] Então, agora a gente conseguiu uma serie de ideias e manobras, eu já tenho e espero que a [próxima coordenadora] também. A gente já tem a "malandragem" de chegar na hora e [dizer]: "Olha ela está fazendo comissão, comitê de ética". Aí eu fico um a um negociando para fechar isso de um jeito mais razoável. [Professores seniores do Programa] eu não deixo de dar aula na graduação. Esses "caras" estão fazendo toda parte da internacionalização, de fato puxando [a produtividade do Programa]. (Coordenador A - Unisinos).

Estes depoimentos têm importância para os objetivos da pesquisa, pois mostram uma das facetas do papel do coordenador no contexto da prática. Os coordenadores adotam uma postura ativa e reflexiva diante da política atual de pós-graduação estabelecida no nível macro, e desenvolvem estratégias e ações intencionais de tradução dessas políticas "no chão" da Universidade, no nível 
micro, no sentido de minimizar os problemas decorrentes da cultura da performatividade na qual os programas estão inseridos.

\section{$\underline{\text { Fragmentação das instancias coletivas }}$}

Por fim, outro efeito da cultura da performatividade perceptível que emergiu dos depoimentos dos entrevistados está relacionado ao tema da fragmentação de instâncias coletivas, que Ball descreve como o "[...] aumento da individualização, incluindo a destruição de solidariedades baseadas numa identidade profissional comum.” (BALL, 2002, p. 9).

Alguns entrevistados percebem a tentativa da Capes de abrir um canal direto de comunicação com os coordenadores como uma forma de enfraquecer as instancias coletivas dos programas. Esta percepção se baseia, primeiramente, na suposição de que a bolsa estudada pela agencia para os coordenadores de programa seria uma forma de abrir um diálogo com esses agentes, sem a mediação de instancias coletivas. Outro fator de enfraquecimento das instâncias coletivas seria a recusa da Capes a se relacionar com associações representativas do campo educacional, como Anped e o Forpred, a ponto da presença de representantes dessas entidades ser omitida em reuniões da Área.

Entretanto, a fragmentação das instâncias coletivas, uma característica da performatividade apontada por Ball, pode ser relativizada diante dos dados levantados por essa pesquisa. Embora tenham surgido indícios de uma possível tentativa, por parte da Capes, de exclusão das associações representativas do debate da política de pós-graduação, o que predominou nos depoimentos dos coordenadores entrevistados foi o fortalecimento do trabalho coletivo nos programas analisados.

Esse fortalecimento é observável quando os coordenadores relatam a ajuda dada aos programas em processo de consolidação na Área da Educação (por meio de parcerias e socialização de conhecimentos de gestão); no fortalecimento dos grupos de pesquisa, que resulta em publicação coletiva de alunos e docentes; e, especialmente, dentro da gestão dos próprios programas, por meio das estratégias de gestão coletivas mencionadas pelos coordenadores e apresentadas no capítulo 5. Podemos afirmar que o trabalho coletivo foi uma das estratégias encontradas 
pelos entrevistados para enfrentar os desafios impostos pela atual política de avaliação da Capes.

\section{2.}

Pierre Bourdieu e as lutas concorrenciais no campo científico

Bourdieu (1983a, 1990, 2004) nos ajuda a compreender as experiências dos coordenadores, ao fornecer chaves de interpretação do campo científico. O autor concebe este campo como um espaço onde ocorre uma luta concorrencial entre os agentes, que mobilizam determinados capitais e lançam mão de estratégias diferenciadas para garantirem melhores posições.

Bourdieu nos ajuda, assim, a perceber o quanto as escolhas dos agentes são geralmente guiadas por essa perspectiva e como as vocações científicas são resultado dessa dinâmica, revelando que o campo científico não é tão "puro", nem é o "reino dos fins" que paira em nosso imaginário.

No caso de nossa pesquisa, foi possível observar que as lutas ocorrem em função das posições ocupadas pelos agentes e que suas estratégias são guiadas pelo seu posicionamento no campo. O posicionamento dos agentes, por sua vez, também é determinado tanto pela função que ocupa (discente, docente, coordenador), como pela posição da sua área de conhecimento ou do seu programa no campo científico.

Em razão disso, optamos conduzir nossas análises de acordo com os diferentes posicionamentos dos agentes frente à "Área da Educação", aos "Programas de pós-graduação", à "coordenação dos programas”, aos “docentes" e aos "discentes".

\section{$\underline{\text { A Área da Educação }}$}

Como vimos, nos depoimentos da maioria dos coordenadores, é possível perceber uma aprovação da avaliação da pós-graduação conduzida pela Capes. Entendemos essa aprovação como um reconhecimento ao fato de ela ter contribuído para uma legitimação da pós-graduação no Brasil, em especial, na Área da Educação, que se desenvolveu tardiamente como campo de investigação científica. 
Nesse sentido, é necessário lembrar que foi na década de 1950 que a produção de pesquisa sobre a realidade educacional nacional, regional, estadual e local, recebeu o aporte da perspectiva das Ciências Sociais (BONAMINO, 2002). Assim, desde o final da década de 1950, projetos educacionais foram sendo desenvolvidos, com o paulatino abandono das preocupações psicopedagógicas, que inspiravam os estudos sobre os processos de ensino, os instrumentos de avaliação da aprendizagem e o desenvolvimento psicológico dos alunos, em favor de pesquisas de natureza sociológica, orientadas para o planejamento, a execução e o acompanhamento de políticas educacionais (GOUVEIA, 1971).

A preocupação brasileira com a consciência da pluralidade cultural também encontrou eco internacional, em face dos efeitos devastadores da ideologia nazista e do êxodo de intelectuais europeus em decorrência da guerra. $\mathrm{O}$ contato dos cientistas sociais brasileiros com alguns desses intelectuais contribuiu para levar aos centros de pesquisa as orientações das Ciências Sociais desenvolvidas na Europa e para deslocar o foco de interesse "das classes dominantes para as classes dominadas" e para as questões culturais e locais (XAVIER, 1999).

A continuidade desta experiência ficou condicionada às mudanças no contexto sociopolítico. O desenvolvimento da pós-graduação e da pesquisa educacional foi então viabilizado pelo novo regime mediante a adoção tanto do tempo integral e da dedicação exclusiva para a maior parte do corpo docente das Universidades públicas, como pelas linhas de financiamento e a concessão de bolsas acionadas para dar suporte à pós-graduação, que forneceram as novas bases institucionais para a pesquisa educacional (CUNHA, 1997).

O desenvolvimento tardio da pesquisa educacional brasileira teve consequências que são sentidas até os dias atuais. Um exemplo disso, é o fato de a Área da Educação só ter atingido a nota 7 na avaliação trienal 2010, além de ter, em termos proporcionais e comparativos com outras Áreas dentro da Capes, um número muito reduzido de programas considerados de excelência.

Bourdieu (1983a) aponta que, no campo científico, existe uma hierarquia social que orienta fortemente as práticas em uma luta concorrencial na qual está em jogo o monopólio da competência científica. 
Nesse sentido, as chamadas Ciências da Natureza possuem a definição mais legítima da forma mais legítima de ciência, que ocupa a posição mais alta na hierarquia dos problemas, domínios e métodos científicos.

Bourdieu alerta, entretanto, que a legitimação dos princípios e critérios científicos não ocorre por meio de um conjunto de normas neutras ou desinteressadas, já que os agentes que as determinam também serão julgados por elas:

Tanto no campo científico quanto no campo das relações de classe não existem instâncias que legitimam as instâncias de legitimidade; as reivindicações de legitimidade tiram sua legitimidade da forma relativa dos grupos cujos interesses elas exprimem: à medida que a própria definição dos critérios de julgamento e dos princípios de hierarquização estão em jogo na luta, ninguém é bom juiz porque não há juízes que não seja, ao mesmo tempo, juiz e parte interessada. (BOURDIEU, 1983a, p.130).

$\mathrm{Na}$ Área de Educação, há uma crítica recorrente de que a Avaliação da Capes se pauta por critérios consagrados nas Áreas das Ciências Exatas e Biológicas. Nos depoimentos dos entrevistados, a crítica encetada ao peso dos critérios, que tem sua importância definida por estas áreas, é no sentido da inadequação da sua generalização para as outras áreas de conhecimento, como ocorre com a prioridade dada à publicação em periódicos científicos e aos índices de impacto.

A própria Capes, no texto do PNPG 2010-2020, reconhece que: "Historicamente, houve a hegemonia ou a predominância de critérios, culturas e procedimentos das Ciências Exatas e Naturais, as quais migraram para outras áreas e funcionaram como uma camisa de força.” (BRASIL, 2010, p.127).

Algumas evidências constatadas na pesquisa corroboram essa crítica, como, por exemplo, a maior valorização do artigo científico em detrimento dos livros. No campo científico, a hierarquia é sustentada por níveis de legitimidade concedidos aos produtos científicos. A Avaliação da Capes e o Sistema Qualis estabelecem essa hierarquia na pós-graduação brasileira, ao privilegiar produtos de áreas mais legitimadas das Ciências Exatas e Biológicas, como é o caso do artigo científico. Outra evidencia objetiva nesse sentido é que os Programas das Áreas das Ciências Humanas e Sociais têm prioridade menor na distribuição de bolsas pela Capes. 
Como as práticas do campo científico estão orientadas para o que Bourdieu chama de "aquisição de autoridade científica", os atores utilizam estratégias diferenciadas para impor uma definição da ciência compatível com o que eles têm, são e fazem. Essa perspectiva ajuda a entender a luta existente na Área da Educação para legitimar o valor do livro como produto científico dentro do Sistema Qualis.

No contexto da prática, nossos entrevistados, enquanto sujeitos posicionados na Área da Educação, de forma geral, mostraram ter consciência de que a Área ainda precisa se posicionar melhor no campo científico. O que muda, no entanto, são as estratégias utilizadas para entrar nessa disputa.

Nesse sentido, percebemos que uma pequena parte dos coordenadores opta por criticar o modelo atual de avaliação, ensaiando timidamente uma "estratégia de subversão". Segundo Bourdieu (1983a) este é um tipo de estratégia que depende de uma mudança nas regras do jogo para render "lucros". Estes coordenadores consideram injusta a Avaliação da Capes se pautar por parâmetros das chamadas ciências duras e mostraram-se indignados com essa situação, na esperança que haja uma mudança. Trata-se de uma postura tímida, uma vez que o discurso, aparentemente, não vem acompanhado de ações mais concretas de subversão.

A maior parte dos coordenadores, entretanto, parece guiar-se por "estratégias de sucessão", que podem assegurar “[...] os lucros prometidos aos que realizam o ideal oficial da excelência científica pelo preço de inovações circunscritas aos limites autorizados [...]” (BOURDIEU, 1983a, p. 138). Os coordenadores que se guiam por essas estratégias não só reafirmam e legitimam as regras hegemônicas das Ciências Exatas e Naturais estabelecidas na Avaliação da Capes, como procuram agir conforme essas mesmas regras, sem considerar necessariamente negativos os parâmetros e metas estabelecidos e os julgamentos realizados, a partir delas, na Área de Educação. Alguns desses coordenadores, inclusive, têm clareza em relação às lutas em jogo no campo científico.

Nesse sentido eu acho que nós temos sido muito frágeis, nós temos dado muita ênfase às discussões das políticas educacionais e pouco às políticas científicas. A gente pouco tem discutido ou tem criado canais de um efetivo dialogo [...] A energia que a gente gasta na discussão das políticas educacionais e da Avaliação da Capes é uma energia que a gente não tem para discutir a política científica, que é onde essas coisas estão sendo discutidas, quer dizer, as regras de organização da comunidade científica, do jogo científico. (Coordenador D - UFMG). 


\section{Os programas de pós-graduação}

Assim como ocorre entre as áreas de conhecimento, a luta concorrencial também acontece entre os programas de pós-graduação. Como vimos, a qualidade dos programas é reconhecida e legitimada pela Avaliação da Capes, que define hierarquias por meio de notas, pautadas na mensuração e classificação dos produtos de seus professores e alunos. Assim, os programas são "de excelência" (nota 6 ou 7), muito bons (nota 5), bons (nota 4) ou regulares (nota 3). No topo dessa hierarquia estão os programas com grande volume de publicações em periódicos classificados nos estratos mais altos do Qualis, condição básica para se tornar um Programa de Excelência.

Os coordenadores, de modo consciente ou não, endossam e buscam esse reconhecimento de seus programas, o que se manifesta em diferentes momentos das entrevistas. Um deles é quando os agentes respaldam a Avaliação da Capes, afirmando que ela colaborou com a melhoria da qualidade da pós-graduação no país. Outro momento é aquele no qual relataram como os professores e as coordenações dos programas decidem buscar a "excelência" acadêmica, agindo de forma a conseguir o reconhecimento de sua qualidade. E um terceiro momento acontece quando introduzem estratégias junto ao corpo discente e docente para alcançar esse reconhecimento.

Segundo Bourdieu (1983a), as práticas no campo científico estão orientadas para a aquisição de autoridade científica, numa luta que leva os produtores a terem como possíveis clientes seus próprios concorrentes. Num campo científico autônomo, um produtor só pode esperar o reconhecimento do valor de seus produtos por outros produtores, que são seus pares.

Assim, entendemos que há um reconhecimento por esse grupo de coordenadores de que a Avaliação da Capes contribuiu com a regulação da pesquisa e do "jogo" científico no país, pela via da avaliação por pares e da definição de regras claras, que são considerados aspectos positivos dessa política de avaliação.

Alguns entrevistados, no entanto, apontaram, como aspecto negativo desse sistema, a associação feita entre mérito e fomento, que pode causar uma injusta distribuição do recurso público, por favorecer programas mais bem estruturados, 
situados em instituições consolidadas e, que, portanto, conseguem atingir os critérios de qualidade com mais facilidade.

Podemos fazer um paralelo entre essa questão e o que Bourdieu (1983a) afirma a respeito da ordem científica estabelecida. Segundo o autor, o mercado dos bens científicos também tem suas próprias leis e a "visibilidade intrínseca" de um nome resulta do fato de que, quanto mais conhecido, mais facilmente ele é reconhecido e retido. Assim como ocorre com o capital econômico, nesse caso, também o capital científico leva a mais capital.

Algo análogo acontece com as Universidades e os programas de pósgraduação no panorama descrito. Os programas de instituições com mais visibilidade e mais recursos acabam sendo mais reconhecidos, tendo mais produtos aprovados, e por fim, conseguindo mais recursos para melhorar seus produtos.

\section{Os coordenadores de programa}

Considerando o conjunto dos profissionais de pós-graduação que atuam na Área da Educação, a posição dos agentes selecionados nessa pesquisa é de "dominância", já que eles participam de programas que fazem parte do restrito grupo dos considerados "de excelência". E, além disso, ocupam/ocuparam um cargo de importância dentro deles, o de coordenação, que demanda tempo institucional para ser conquistado. Nossos entrevistados são docentes que possuem um maior volume de "capital científico" e de "capital institucional" que os professores novatos. Por conta disso, eles encaminham e aprovam as regras do jogo em vigor no campo e têm mais facilidade para "jogar" de acordo com elas, utilizando estratégias de conservação.

Através dos seus depoimentos é possível perceber estratégias de conservação dos entrevistados em diversos momentos. Os coordenadores aprovam o processo de Avaliação da Capes, assim como os parâmetros de produção científica estabelecidos para a pós-graduação, relativos à publicação docente e discente, como no trecho que segue:

Ainda hoje você tem esse discurso: 'ah, estamos nos preocupando com a publicação e estamos nos despreocupando com a formação'. A meu ver, isso é uma dicotomia equivocada. Porque na hora que você forma o mestre, $[. .$.$] mas particularmente o doutor, considerando-o um$ futuro pesquisador, formar para publicar é parte do processo. Inseri-lo 
na dinâmica de como é o processo de produção do conhecimento, faz parte do processo de publicar. Então, eu acho que tem que ter essa característica indutora importante. (Coordenador B - Uerj)

E entendem como infundada a crítica da Área de Educação ao produtivismo ensejado pela avaliação dos programas, já que consideram razoável o patamar de produção científica exigido pela Capes e fácil de ser atingido. Em suas falas, eles comentam que, já tendo orientandos de mestrado e doutorado, é simples manter níveis altos de produção, já que seus produtos acabam se constituindo de coautorias com os alunos.

De acordo com Bourdieu (1983a), os dominantes têm mais vantagens acumuladas e maiores possibilidades de acumular capital científico na luta concorrencial que ocorre no meio acadêmico, pois entram nessa luta com um maior volume de capitais. É essa posição no campo que incide na visão desse grupo sobre as facilidades e possibilidades de atingir as metas de produção intelectual estabelecidas pela Capes, revelando suas estratégias e reconhecendo, inclusive, a maior dificuldade enfrentada por docentes novatos em relação a isso.

Outro ponto que sinaliza a posição de dominância dos coordenadores é que, nas experiências da Uerj e UFMG, pessoas mais influentes nos programas vão "costurando" um nome para ocupar o cargo da nova coordenação quando se aproxima o final do mandato. Nas falas dos coordenadores, é possível perceber questões relativas a articulações políticas, em termos como "conversa aqui, conversa ali”, "o nome cresceu”, "costura prévia”. Também é possível perceber questões de hierarquia e de desigualdade de força entre os professores ("pessoas de maior influência", "o nome é colocado por alguém”, “a gente tem que ir cercando alguém”). Ou seja, a escolha do nome de um coordenador não ocorre de maneira neutra, é uma escolha política que envolve agentes com diferentes "pesos" políticos/hierárquicos, em virtude dos volumes de capital científico acumulados.

O fato de haver grupos de influência, geralmente com mais tempo na instituição e com maior poder de decisão, está relacionado à concepção de Bourdieu (1983a, p. 136) sobre o campo científico, visto como “[...] o lugar de uma luta, mais ou menos desigual, entre agentes desigualmente dotados de capital específico." 
Segundo os depoimentos, assumir as atribuições de coordenador de programa, acaba interferindo negativamente na acumulação de capital científico porque afeta as atividades de pesquisa desses docentes, além de ocupá-los em uma tarefa que, como a gestão, demanda tempo para ser cumprida.

Bourdieu (2004) nos remete especificamente para a questão da dificuldade dos gestores para manter seu nível de produção acadêmica, ao tratar do tema do "capital científico institucionalizado". De acordo com o autor, a dificuldade de acumulação de capital científico puro (relacionado ao progresso da ciência, como invenções, descobertas, publicações) é maior entre os indivíduos com maior capital científico institucional, relacionado à ocupação de cargos, por exemplo, porque a acumulação de capital institucional demanda estratégias políticas que exigem tempo para ser conquistada.

Assumir a responsabilidade da coordenação, todavia, pode trazer vantagens na medida em que é uma estratégia de visibilidade, que propicia o reconhecimento do outro. De acordo com Bourdieu, na busca pela visibilidade, não há escolha científica que não seja uma estratégia política de investimento objetivamente orientada para a maximização do lucro científico, na forma de reconhecimento dos pares.

Entretanto os coordenadores nem sempre fazem essa escolha de forma consciente. Bourdieu lembra que as escolhas, muitas vezes, não são evidentes para os agentes, pois, em geral, as estratégias não são calculadas nem intencionais. Trata-se de uma luta, na maioria das vezes, não consciente pelo poder (THIRYCHERQUES, 2006).

Todos os coordenadores também mencionaram que já fizeram parte de outras instancias de coordenação (comissão coordenadora, colegiado etc.), antes de se tornarem coordenadores, o que os preparou, em parte, para a função. Nesse caso, é interessante apontar que a ocupação do cargo de coordenador para os professores que já ocuparam outras funções institucionais dentro do programa, mostra como o capital científico institucional pode ser acumulado, de forma a favorecer quem já o possui, assim como ocorre com o capital econômico (BOURDIEU, 2004).

Segundo Thiry-Cherques (ibid.), os agentes ou as instituições lutam para determinar a distribuição do capital específico, acumulado no curso de lutas anteriores, que orienta as estratégias vindouras. A nossa posição em um campo 
determina a forma como produzimos e acumulamos. Assim, quem possui capital institucionalizado, tende a acumulá-lo cada vez mais. No caso dos coordenadores de programas entrevistados, eles já possuíam capital institucional, por terem participado de outros espaços da gestão, e isso favoreceu um maior acúmulo desse mesmo tipo de capital, mediante a "ocupação" do cargo de coordenador.

Após ocuparem o cargo de coordenação, os agentes também utilizam estratégias de conservação, como pode ser observado no caso do Programa da UFMG. As estratégias de conservação do grupo dominante estão, inclusive, institucionalizadas através da Comissão de Acompanhamento e Avaliação Docente e das regras estabelecidas em portaria sobre sua composição. O documento determina que são "[...] membros natos da comissão o subcoordenador do Programa e os docentes em atividade que já tenham sido eleitos e exercido o cargo de Coordenador do Programa" (UFMG, 2007, p. 2).

Dessa forma, o fato de ter sido coordenador garante a presença na comissão de forma permanente. Se pensarmos na força dessa comissão no andamento das questões gerais e nos rumos do Programa, essa é uma estratégia poderosa de conservação do grupo dominante do Programa da UFMG, que acaba contribuindo para a distribuição desigual do capital científico entre novatos e "seniores".

Como vimos, a Comissão de Acompanhamento e Avaliação Docente, ocupa um lugar central no processo de coordenação do Programa. Segundo as falas dos entrevistados, seus componentes (os ex coordenadores), além de experiência na gestão, têm o respaldo da comunidade acadêmica, que os respeita e lhes confere autoridade. O grupo tem legitimidade dentro do Programa:

A comissão de acompanhamento e avaliação dos professores, que tem hoje um papel muito importante no Programa de atuação junto com a coordenação [...], é uma comissão que tem um lugar institucional muito forte. (Coordenador D - UFMG).

É como se houvesse uma cultura organizacional de um setor, que hoje é o setor sênior do Programa, que viveu um momento e que cultivou isso, assim como tirou lição disso e que trabalha no sentido de pensar o futuro. (Coordenador A - UFMG).

No caso da UFMG, a legitimidade do grupo dos ex-coordenadores é reconhecida, eles falam e agem de maneira autorizada e com a autoridade conferida pelo pertencimento a esse grupo específico e pelo capital científico 
institucionalizado que possuem. Neste caso, o capital institucionalizado do grupo advém, também, do fato desses agentes já terem ocupado o cargo de coordenação.

A consequência positiva desse arranjo institucional é que, segundo os coordenadores, quem é novo no cargo, mesmo no caso de sentir insegurança em relação à sua nova posição na hierarquia institucional, se beneficia da autoridade reconhecida do grupo dos ex-coordenadores ao realizar suas atividades de gestão, se sentido mais confiante ao tomar decisões relacionadas ao cargo.

Por fim, a legitimidade desse grupo é transmitida para os coordenadores novatos, que são apoiados pela comissão de acompanhamento docente formada pelos professores seniores. Neste caso, o professor novato no cargo acaba fazendo uso daquilo que Bourdieu (1983a) chama de estratégia de sucessão. Segundo o autor, é o próprio campo que designa estratégias a cada agente e os novatos, de acordo com suas trajetórias sociais, podem orientar-se por estratégias de sucessão, mais seguras e previsíveis, dentro de limites "autorizados".

\section{Os docentes}

Nas quatro experiências analisadas houve um enrijecimento dos critérios de entrada/ permanência dos docentes nos programas de pós-graduação, com base, especialmente, nas formas de divulgação de suas produções científicas. Isto mostra, de forma concreta, as regras do jogo estabelecidas na luta pela entrada e permanência dos professores no campo científico em questão, ou seja, nos programas de pós-graduação.

As regras estão bastante claras para os coordenadores que já atuam nos programas e houve um processo de sistematização dessas regras para os interessados em participar do "jogo", como, por exemplo, o estabelecimento de um número mínimo de publicações, a inserção em grupo de pesquisa etc. Em alguns casos, inclusive, as regras foram formalizadas em documentos institucionais oficiais.

Essa situação, de fato, rompe com a imagem idealizada de ciência enquanto "reino dos fins" da qual nos fala Bourdieu, mostrando que as práticas científicas não são ingênuas ou desinteressadas. As regras estabelecidas em cada um dos casos relacionam-se diretamente aos "produtos" que a prática do professor/pesquisador pode gerar, especialmente à publicação de artigos em 
periódicos qualificados e ao financiamento de pesquisa. Esses produtos científicos são os que sustentam a legitimidade dos agentes dentro do campo científico. No caso específico, os agentes lutam pela "autoridade" de ser ou não professor em um programa de pós-graduação.

\section{$\underline{\text { Os discentes }}$}

A questão da hierarquia no campo científico está também relacionada ao tema da seleção de candidatos à pós-graduação. Os programas analisados afunilaram os critérios de seleção de novos alunos, estabelecendo que os candidatos precisam estar sintonizados com os objetos e temas das pesquisa desenvolvidas pelos docentes.

Neste caso, os docentes, portadores de um maior volume de capital científico e melhor posicionados no campo, têm o poder de recusar a entrada de um novo candidato, impondo suas regras.

Os candidatos, por sua vez, novatos no campo científico, estão em uma luta concorrencial pela vaga no programa e pela futura inserção no campo. Para saírem vencedores na luta que travam com os demais candidatos, e conquistarem um melhor posicionamento no campo, se tornando alunos de pós-graduação, precisam se submeter às regras impostas, alinhando seus projetos aos projetos dos docentes.

Nesse sentido, é possível compreender porque Bourdieu (1983a) postula que as "vocações" científicas, na verdade, são guiadas pela hierarquia social que permeia o campo:

\footnotetext{
Não há "escolha" científica [...] que não seja uma estratégia política de investimento objetivamente orientada para a maximização do lucro propriamente científico, isto é, a obtenção do reconhecimento dos pares-concorrentes. [...] Existe assim, a cada momento, uma hierarquia social dos campos científicos, as disciplinas que orienta fortemente as práticas e, particularmente, as "escolhas" de "vocação". No interior de cada um deles há uma hierarquia social dos objetos e dos métodos de tratamento. (Ibid., p. 126-128).
}

No caso desses candidatos, não é infundado pensar, por exemplo, que poderão ocorrer adaptações em seus projetos iniciais, de forma a que eles se alinhem mais a uma pesquisa do programa e tenha mais chances de ser aprovado no processo seletivo. 
Contexto dos resultados ou efeitos para os programas

Neste capítulo analisaremos tanto os resultados dos programas, como os "efeitos" decorrentes da chancela de "excelência" recebida da Capes, em termos de mudanças que podem ser captadas por um conjunto de indicadores utilizados na avaliação trienal, como a percepção dos coordenadores em relação às consequências materiais e simbólicas de tal mudança.

Segundo Mainardes, no ciclo de políticas proposto por Ball, o contexto dos resultados pode comportar efeitos de primeira ou de segunda ordem:

Os efeitos de primeira ordem referem-se a mudanças na prática ou na estrutura e são evidentes em lugares específicos ou no sistema como um todo. Os efeitos de segunda ordem referem-se ao impacto dessas mudanças nos padrões de acesso social, oportunidade e justiça social. (MAINARDES, 2006, p.55).

Tendo em vista os limites e objetivos dessa pesquisa, nossa análise está circunscrita a alguns dos "efeitos de primeira ordem" identificados nos programas pesquisados. A identificação desses "efeitos" será realizada em dois momentos. Em um primeiro momento, observaremos as mudanças em relação a aspectos da titulação do corpo discente e da produção intelectual desses programas, tendo por base os Cadernos de Indicadores e os Relatórios de Avaliação Trienal divulgados pela Capes. Em um segundo momento, a identificação desses efeitos será feita tendo por base as considerações dos coordenadores sobre as mudanças provocadas pela conquista e manutenção da excelência, principalmente pelas injunções materiais e simbólicas resultantes da avaliação da Capes.

\section{1.}

\section{Mudanças nos dados dos programas}

Como vimos no Capítulo 4, entre os quesitos de Avaliação da Capes, os que ganharam peso maior nas Avaliações Trienais realizadas entre 2001 e 2013, e que hoje são mais valorizados, estão aqueles relativos à produção intelectual do corpo docente (Produção Intelectual, com peso 35) e ao corpo discente (Corpo Discente, Teses e Dissertações, com peso 35). 
Esses quesitos serão analisados em relação aos Programas da PUCRS, Uerj, UFMG e Unisinos, a partir das informações disponibilizadas nos Cadernos de Indicadores e nos Relatórios das Avaliações Trienais de cada um dos Programas. As informações selecionadas referem-se ao período 2001-2009 e foram organizadas com base nos triênios de avaliação correspondentes. No triênio 2004, a Capes avaliou os dados relativos aos anos de 2001, 2002 e 2003; no triênio 2007, os dados de 2004, 2005 e 2006; e no triênio 2010, os dados de 2007, 2008 e 2009. É importante frisar, portanto, que os resultados não se referem ao ano da avaliação, mas sim, a uma média dos três anos que compõem o triênio.

As informações foram separadas em quatro quadros. A seguir, apresentamos os dados relativos à formação e produção intelectual dos discentes nos programas analisados. 


\section{Quadro 7 - Dados relativos à formação e produção intelectual dos discentes nos Programas analisados (triênios 2004 a 2010)}

\begin{tabular}{|c|c|c|c|c|c|c|c|c|c|c|}
\hline 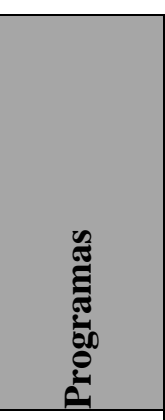 & 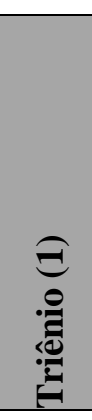 & 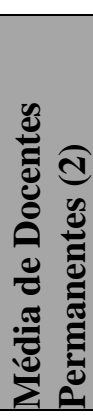 & 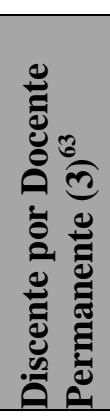 & 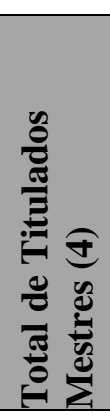 & 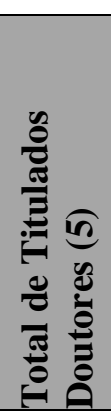 & 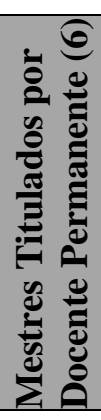 & 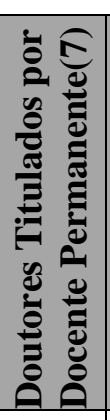 & 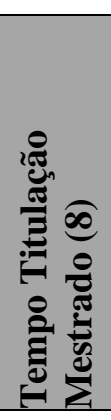 & 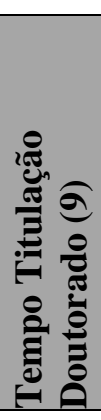 & 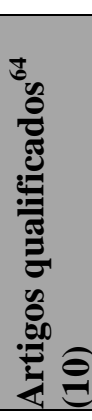 \\
\hline \multirow{3}{*}{ PUCRS } & 2004 & 15 & 11,8 & 114,0 & 21,0 & 7,6 & 1,4 & 28,9 & 48,1 & 76 \\
\hline & 2007 & 15 & 8,6 & 66,0 & 20,0 & 4,3 & 1,3 & 25,8 & 46,8 & 29 \\
\hline & 2010 & 13 & 12 & 69,0 & 43,0 & 5,3 & 3,3 & 24,3 & 46,6 & 34 \\
\hline \multirow{3}{*}{ Uerj $^{65}$} & 2004 & 19 & 4,1 & 94,0 & - & 5 & & 29,9 & - & 3 \\
\hline & 2007 & 21 & 7 & 95,0 & 19,0 & 4,5 & 0,8 & 29,2 & 34,2 & 43 \\
\hline & 2010 & 24 & 6 & 93,0 & 35,0 & 3,8 & 1,4 & 28,9 & 47,1 & 40 \\
\hline \multirow{3}{*}{ UFMG } & 2004 & 33 & 3,9 & 169,0 & 34,0 & 5 & 1,1 & 37 & 52,4 & 35 \\
\hline & 2007 & 48 & 5,5 & 108,0 & 56,0 & 2,3 & 1,2 & 31,4 & 50,2 & 38 \\
\hline & 2010 & 59 & 6,8 & 195,0 & 89,0 & 3,3 & 1,5 & 30,7 & 49,7 & 76 \\
\hline \multirow{3}{*}{ Unisinos } & 2004 & 15 & 2,7 & 53,0 & 6,0 & 3,5 & 0,4 & 32,5 & 42,7 & 35 \\
\hline & 2007 & 19 & 10 & 72,0 & 16,0 & 3,8 & 0,8 & 27,3 & 50,5 & 39 \\
\hline & 2010 & 14 & 6 & 81,0 & 43,0 & 5,8 & 3,1 & 26,4 & 48,2 & 53 \\
\hline
\end{tabular}

Fonte: Capes/ Cadernos de Indicadores dos Programas (2001-2009) e Relatórios das Avaliações Trienais 2007 e 2010.

A fim de termos uma ideia geral da dimensão dos Programas ao longo do período analisado, o primeiro dado apresentado é o relativo ao tamanho do corpo docente permanente. É possível perceber que houve ampliação do número de docentes permanentes nos Programas das Universidades públicas entre o triênio

\footnotetext{
${ }^{63}$ No triênio 2004, o calculo foi baseado no número de discentes por docente no NRD (Núcleo de Referência Docente).

${ }^{64}$ Consideramos a contagem dos artigos de acordo com a autoria discente. Dessa forma, artigos nos quais um discente do programa aparece como autor foi contado uma vez, artigos nos quais dois discentes do programa aparecem como autores foram contados duas vezes, e assim sucessivamente. Nessa contagem, levamos em consideração apenas os artigos classificados pelo Sistema Qualis nos três triênios.

${ }^{65}$ As diferenças percentuais dos dados sobre doutorado no Programa da UERJ foram calculadas entre os triênios 2007 e 2010.
} 
2004 e o triênio 2010. Nesse intervalo, na Uerj, a média de docentes permanentes era de 19 e passou para 24, o que significou um acréscimo de 5 docentes permanentes ao quadro no período. Na UFMG, o aumento foi mais significativo, já que a média, no triênio 2004, era de 39 docentes permanentes, e, em 2010, passou para 59 , um aumento de $79 \%$.

Nas Universidades privadas, por sua vez, houve uma redução do quadro de docentes permanentes. Ambas as instituições apresentaram média de 15 docentes permanentes no triênio 2004, sendo que, no triênio 2010, a Unisinos teve um docente permanente a menos e a PUCRS teve dois docentes permanentes a menos.

Analisando-se as colunas relativas ao tamanho do corpo docente (coluna 2) e à média de discentes por professor do quadro permanente (coluna 3), podemos constatar que tanto a redução no número de professores, no caso da PUCRS e da Unisinos, quanto a ampliação do quadro docente, no caso da Uerj e da UFMG, foram acompanhadas do aumento da média de discentes por docente permanente. No triênio 2010, há um melhor equacionamento da média de pós-graduandos por docente permanente nos programas da Uerj (6), UFMG (6,8) e Unisinos (6) e uma média mais alta no caso do programa da PUCRS (12).

Em relação à titulação de mestres e doutores, observamos, analisando as colunas (4) e (5), que, em todos os programas, houve um crescimento significativo no número de doutores titulados, que não foi acompanhado na mesma proporção pelo crescimento do número de mestres.

Ao analisarmos cada Programa em particular, podemos observar que, no Programa da PUCRS, houve uma redução expressiva no número de mestres titulados, que passou de 114 em 2004 para 69, em 2010, enquanto mais do que dobrou o número de doutores egressos na trienal 2010 em relação à de 2004, passando, respectivamente, de 21 para 43 doutores titulados.

No Programa da UFMG, por sua vez, houve uma aumento na titulação de mestres da ordem de $15 \%$ em 2010 , em relação ao total de mestres titulados em 2004. No mesmo período, passou de 34 para 89 o número de doutores titulados, o que representa um aumento de quase $70 \%$ no total de doutores egressos.

Já os dados sobre titulação de doutores na Unisinos e na Uerj precisam ser analisados levando em consideração o fato de que esses Programas iniciaram seus cursos de doutorado, respectivamente, em 1999 e em 2002. 
Os dados da Unisinos revelam que o Programa apresentou um crescimento significativo no número de mestres titulados, passando de 53, no triênio 2004, para 81 , no triênio 2010 , o que representa um aumento de $53 \%$ no total de mestres egressos, apesar de ter passado por uma redução no tamanho do quadro de docentes permanentes. Em relação à titulação de doutores, a Unisinos teve apenas 6 doutores formados no triênio 2004 e 43 em 2010, ou seja, um aumento de cerca de $70 \%$ na titulação de doutores no triênio avaliado em 2010.

Na Uerj, o número de mestres titulados se manteve estável entre a trienal de 2004 e a de 2010 , tendo titulado 35 doutores somente na avaliação trienal de 2010.

Já a análise das informações das colunas (6) e (7), relativas à média de titulados mestres e doutores por docente permanente do Programa, nos permite verificar que, na maior parte dos Programas: houve uma redução no número de mestres titulados por docentes permanentes acompanhada do aumento no número de doutores titulados por docentes permanentes. Estão nessa situação os Programas da PUCRS, Uerj e UFMG que, respectivamente, reduziram em 30\%, $24 \%$ e $34 \%$ o número de mestres titulados por docente permanente, ao passo em que ampliaram em 136\%, 75\% e 36\%, respectivamente, o número de doutores.

A exceção fica por conta da Unisinos, único Programa a ampliar concomitantemente o número de mestres titulados por docente permanente, de 3,5 para 5,8 , e o de doutores, que passou de 0,4 para 3,1 .

Esses dados estão em sintonia com as exigências da Capes em termos de formação de quadros para a pós-graduação por programas com notas 6 e 7, uma vez que, segundo a Capes, este precisam alcançar um nível altamente diferenciado dos demais programas da área em termos de produção intelectual e de formação de doutores (Capes, 2013c).

Por fim, as informações das colunas (8) e (9), relativas ao tempo médio de titulação de mestres e doutores, mostram uma tendência à diminuição dos prazos, principalmente no que respeita ao tempo médio de titulação de mestres, que diminuiu em todos os Programas.

Na PUCRS, o tempo médio de titulação de mestres passou de 28,9 meses para 24,3 meses; na Uerj de 29,9 para 28,9; na UFMG de 37 para 30,7; e na Unisinos de 32,5 para 26,4, num claro movimento de ajuste aos prazos máximos fixados pela Capes (30 meses). 
No caso do tempo de titulação do doutorado, observa-se um movimento semelhante apenas no Programa da PUCRS, que reduziu o tempo de titulação de 48,1 para 46,6 meses; e no Programa da UFMG, que passou de 52,4 para 49,7.

Nos Programas da Uerj e Unisinos, o tempo de titulação de doutores teve algumas flutuações, permanecendo sempre abaixo ou muito próximo do prazo máximo de 48 meses fixado pela Capes.

Ainda sobre os prazos de titulação, como adiantamos no capítulo 5, as médias das Universidades públicas são, em sua maioria, mais altas que nas Universidades privadas.

Em síntese, a análise do quadro 7, revela ajustes dos Programas à política de avaliação da Capes, no que diz respeito, notadamente, à redução do tempo de titulação dos alunos e à ênfase na formação de doutores (CAPES, 2010, p. 12).

Não é descabido pensar que o aumento do corpo discente em relação ao corpo docente e no de alunos titulados por docente permanente, em um contexto que exige a redução dos tempos de titulação, tenha representado uma sobrecarga de trabalho para os professores, na medida em que cada um deles passa a orientar mais doutorandos e a dispor de um prazo menor até a sua titulação.

Por fim, o quadro ainda apresenta os dados relativos à produção de artigos qualificados dos discentes dos Programas. A análise dessa coluna (10) mostra que nos programas da Uerj, UFMG e Unisinos houve aumento da produção qualificada dos discentes. Na Uerj, essa produção aumentou de 3, no triênio 2004, para 40, no triênio 2010; na UFMG passou de 35 para 76; e na Unisinos de 35 para 53. Esses resultados denotam que as estratégias adotadas junto ao corpo discente, relativas à seleção de candidatos com perfil acadêmico de pesquisa, participação em pesquisa e incentivo à publicação surtiram efeito ao longo do período analisado. Com maior atenção e cobrança em relação à produção dos alunos, esses programas viram as publicações discentes aumentarem significativamente.

O ponto de inflexão neste item é representado pelo Programa da PUCRS, que apresentou uma queda significativa na Produção Intelectual, expressa pela diferença entre os 76 produtos discentes contabilizados no triênio 2004 e os 34 do triênio 2010. Contribuiu para essa diferença o fato de que, no ano de 2003, um único artigo foi assinado por 20 alunos e outro por 6 alunos, o que elevou o número de produtos discentes contabilizados para o Programa nesse triênio. 
Como complemento à análise dos dados relativos à formação e produção discente, vamos verificar, a seguir, a evolução dos dados relativos à produção intelectual dos docentes permanentes no período considerado. Como já vimos, entre todos os produtos da pós-graduação, o artigo científico é o mais valorizado. A Área da Educação, entretanto, conseguiu que capítulos e livros também fossem considerados na Avaliação da Capes. Em razão disso, o quadro 8, apresenta os dados referentes à produção de artigos, livros (obra completa) e capítulos de livros.

\section{Quadro 8 - Publicação dos docentes permanentes nos Programas analisados (triênios 2004 a 2010) ${ }^{66}$}

\begin{tabular}{|c|c|c|c|c|c|c|}
\hline 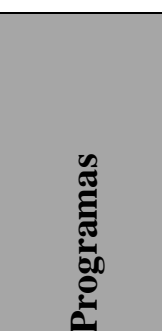 & 号 & 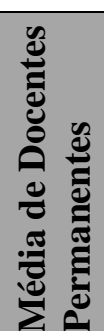 & 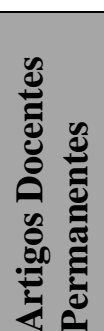 & 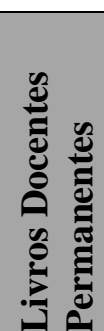 & 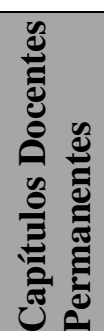 & 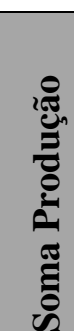 \\
\hline \multirow{3}{*}{ PUCRS } & 2004 & 15 & 57 & 1 & 80 & 138 \\
\hline & 2007 & 15 & 58 & 3 & 89 & 150 \\
\hline & 2010 & 13 & 68 & 1 & 111 & 180 \\
\hline \multirow{3}{*}{ Uerj } & 2004 & 19 & 76 & 17 & 100 & 193 \\
\hline & 2007 & 21 & 84 & 17 & 126 & 227 \\
\hline & 2010 & 24 & 96 & 20 & 254 & 370 \\
\hline \multirow{3}{*}{ UFMG } & 2004 & 33 & 107 & 14 & 82 & 203 \\
\hline & 2007 & 48 & 174 & 36 & 188 & 398 \\
\hline & 2010 & 59 & 212 & 32 & 290 & 534 \\
\hline \multirow{3}{*}{ Unisinos } & 2004 & 15 & 69 & 11 & 56 & 136 \\
\hline & 2007 & 19 & 114 & 21 & 111 & 246 \\
\hline & 2010 & 14 & 89 & 12 & 135 & 236 \\
\hline
\end{tabular}

Fonte: Capes/ Cadernos de Indicadores dos Programas (2001 - 2009).

Observando o quadro 8, é possível constatar que, entre os triênios 2004 e 2010, excetuando a categoria livro na $\operatorname{PUCRS}^{67}$, a produção dos docentes

\footnotetext{
${ }^{66}$ Consideramos a contagem dos artigos de acordo com a autoria docente. Dessa forma, artigos nos quais um docente do programa aparece como autor foi contado uma vez, artigos nos quais dois docentes do programa aparecem como autores foram contados duas vezes, e assim sucessivamente.

${ }^{67}$ O Programa manteve a média de uma publicação na categoria livro nos triênios 2004 e 2010.
} 
permanentes aumentou em todos os veículos de publicação considerados (artigos, livros e capítulos) e em cada um dos Programas investigados pela pesquisa.

Vamos começar a análise com os resultados apresentados pelos Programas das Universidades privadas, que tiveram seus quadros de docentes permanentes reduzidos. O Programa da PUCRS, que perdeu 2 docentes permanentes no triênio 2010, manteve a produção de livros e aumentou a produção de artigos de 57 para 68, e de capítulos de livros de 80 para 116. No total, a ampliação da produção foi da ordem de $30 \%$. O Programa da Unisinos, que teve um docente permanente a menos no quadro, passou de 69 artigos, 11 livros e 56 capítulos em 2004 para 89 artigos, 12 livros e 135 capítulos em 2010. Assim, enquanto o grupo de 15 docentes permanentes de 2004 teve 136 produtos, o grupo de 13 docentes de 2010 teve 236 produtos, resultando em um aumento de $74 \%$. Não podemos deixar de mencionar, também, que, no triênio de 2007, quando houve uma ampliação do quadro de docentes permanentes na Unisinos (média de 19 docentes), o Programa atingiu os maiores resultados em termos quantitativos na produção de artigos (114) e capítulos (21), assim como na soma total da produção (246 produtos).

$\mathrm{Na}$ Uerj, onde o quadro de docentes permanentes foi ampliado em $26 \%$, o número de artigos passou de 76 para 96, o de livros de 17 para 20 e de capítulos de 100 para 254, o que representa um aumento de $92 \%$ no total de publicações.

Na UFMG, por sua vez, a ampliação do quadro docente foi de $79 \%$, e a produção aumentou em 163\%; já que o número de artigos subiu de 107 para 212, de livros de 14 para 32 e de capítulos de 82 para 290.

Assim, nos Programas das universidades públicas, que tiveram uma ampliação do quadro de docentes permanentes, ocorreu um aumento proporcionalmente maior no número de produtos bibliográficos.

Em todos os Programas pesquisados, os dados apontam para o crescimento progressivo da produção, proporcionalmente maior no total de artigos, livros e capítulos do que de docentes.

No entanto, estes dados se referem apenas aos aspectos quantitativos da produção bibliográfica, sem que se leve em conta a classificação qualitativa, conferida pelo Sistema Qualis a essa produção.

Sabemos que a Capes considera como um dos principais critérios para a classificação de Programas de Excelência a publicação bibliográfica em veículos de padrão internacional. Na avaliação trienal 2010, por exemplo, o principal 
critério para avaliação desses programas foram os produtos dos docentes permanentes vinculados em periódicos A1 e A2 e livros e capítulos L4. Ao longo dos três triênios, entretanto, houve mudanças nos critérios de avaliação da produção bibliográfica dos programas, tanto em função da alteração do peso desse quesito e dos seus itens, como em função dos pesos utilizados para o cálculo das médias ponderadas de produção. Além disso, também houve mudanças em função das alterações da classificação de periódicos no Sistema Qualis, ocorrida em 2008.

No caso dos periódicos, nas Avaliações Trienais 2004 e 2007, vigorou o sistema antigo, no qual os produtos eram avaliados como Internacional, Nacional ou Local, nos níveis A, B e C. Na avaliação trienal 2010 foi a vez do novo sistema, no qual os produtos são classificados como A1, A2, B1, B2, B3, B4 e B5.

Diante disso, na análise comparativa das produções qualificadas ao longo do período, consideramos os artigos publicados em periódicos avaliados como "Internacional A" e "Internacional B" nos triênios 2004 e 2007. De modo a ampliar a comparação, recorremos também aos dados do triênio 2001, que permitem uma noção mais apurada da evolução desses dados, como pode ser observado no quadro 9.

A análise comparativa da produção dos Programas em termos qualitativos ao longo dos triênios, portanto, fica enviesada pela mudança ocorrida no Sistema Qualis em 2008, já que não podemos comparar diretamente os resultados de antes e depois da mudança. Por isso, apresentaremos separadamente no quadro 10 as publicações de artigos considerados A1 e A2 no triênio 2010.

Por fim, também não foi possível apresentar dados comparáveis relativos à produção qualificada de livros, já que não houve a divulgação dessa classificação nos cadernos de indicadores. A mesma consta apenas nos Relatórios das Avaliações Trienais 2007 e 2010, que não são comparáveis entre si, já que na trienal 2007 foi usado o antigo sistema, no qual os livros eram classificados Internacional, Nacional ou Local, nos níveis A, B e C, e, na trienal 2010, o sistema atual, que classifica os livros nos estratos L4, L3, L2, L1 e LNC. 


\section{Quadro 9 - Produção docente em periódicos Internacionais A e B por triênio (2001 a 2007) ${ }^{68}$}

\begin{tabular}{|c|c|c|c|}
\hline Programa & Triênio & IA & IB \\
\hline \multirow{3}{*}{ PUCRS } & $\mathbf{2 0 0 1}$ & 0 & 0 \\
\cline { 2 - 4 } & $\mathbf{2 0 0 4}$ & 2 & 2 \\
\cline { 2 - 4 } & $\mathbf{2 0 0 7}$ & 3 & 4 \\
\hline \multirow{3}{*}{ Uerj } & $\mathbf{2 0 0 1}$ & 0 & 0 \\
\cline { 2 - 4 } & $\mathbf{2 0 0 4}$ & 12 & 7 \\
\cline { 2 - 4 } & $\mathbf{2 0 0 7}$ & 19 & 13 \\
\hline \multirow{3}{*}{ UFMG } & $\mathbf{2 0 0 1}$ & 3 & 0 \\
\cline { 2 - 4 } & $\mathbf{2 0 0 4}$ & 19 & 3 \\
\cline { 2 - 4 } & $\mathbf{2 0 0 7}$ & 40 & 9 \\
\hline \multirow{3}{*}{ Unisinos } & $\mathbf{2 0 0 1}$ & 0 & 1 \\
\cline { 2 - 4 } & $\mathbf{2 0 0 4}$ & 5 & 3 \\
\cline { 2 - 4 } & $\mathbf{2 0 0 7}$ & 12 & 4 \\
\hline
\end{tabular}

Fonte: Capes/ Cadernos de Indicadores dos Programas "Produção Bibliográfica" (19982006).

Analisando o quadro 9, que toma como ponto de partida a produção do Triênio 2001, podemos constatar que, assim como no caso dos dados quantitativos da produção bibliográfica, em todos os Programas, nos dois níveis de classificação (IA e IB), houve aumento da produção qualificada em relação ao triênio anterior. No triênio 2001, apenas os docentes do Programa da UFMG publicaram 3 artigos em periódicos Internacional A, e a Unisinos 1 artigo Internacional B. No triênio 2007, a produção em periódicos Internacional A foi de 3 produtos na PUCRS, de 19 produtos na Uerj, e subiu para 40 produtos na UFMG e para 12 na Unisinos. Já a produção em periódicos classificados no estrato internacional B foi de 4, 13, 9 e 4 produtos, respectivamente.

\footnotetext{
${ }^{68}$ Consideramos a contagem dos artigos de acordo com a autoria docente. Dessa forma, artigos nos quais um docente do Programa aparece como autor foi contado uma vez, artigos nos quais dois docentes do Programa aparecem como autores foram contados duas vezes, e assim sucessivamente.
} 


\section{Quadro 10 - Produção docente em} periódicos A1 e A2 (triênio 2010) ${ }^{69}$

\begin{tabular}{|l|c|c|c|}
\hline Programa & Triênio & A1 & A2 \\
\hline PUCRS & $\mathbf{2 0 1 0}$ & 1 & 14 \\
\hline Uerj & $\mathbf{2 0 1 0}$ & 14 & 34 \\
\hline UFMG & $\mathbf{2 0 1 0}$ & 41 & 45 \\
\hline Unisinos & $\mathbf{2 0 1 0}$ & 4 & 17 \\
\hline
\end{tabular}

Fonte: Capes/ Cadernos de Indicadores dos Programas "Produção Bibliográfica" (20072009).

Como já afirmamos, não há uma correspondência exata entre os níveis do antigo e do novo sistema. Sabemos, entretanto, que os critérios foram modificados com o objetivo de permitir uma maior discriminação na produção acadêmica. Isto indica que houve um movimento inicial de redução do número de periódicos classificados nos níveis mais altos. Contudo, é interessante notar no quadro apresentado, que a produção nos dois níveis mais altos de classificação (nesse caso, A1 e A2) continuou expressiva e aumentou após a mudança.

Para efeitos comparativos da quantidade de produtos, somamos o número de artigos em periódicos A1 e A2 no triênio 2010, e obtivemos os seguintes resultados: PUCRS com 15 produtos, Uerj com 48, UFMG com 86 e Unisinos com 21. Já quando somamos os artigos em periódicos Internacional A e Internacional B nos triênios anteriores (2001, 2004 e 2007) obtivemos um total de: 11, 51, 76 e 25 produtos, respectivamente. Ou seja, os resultados dos três triênios anteriores ficaram muito próximos do resultado do triênio 2010 na Uerj (51 e 48) e na Unisinos (25 e 21) e são ultrapassados na PUCRS (11 e 15) e na UFMG (76 e 86).

$\mathrm{Na}$ Avaliação da Capes, não é feita a soma total de produtos que têm níveis de classificação diferentes. No cálculo, são atribuídos pesos diferenciados para cada estrato do Qualis e é calculada a média ponderada dos produtos. Como houve muitas mudanças nas ponderações ao longo dos triênios, nos limitamos a fazer apenas a soma total da produção mais qualificada, sem considerar seus pesos, pois o objetivo é analisar essas diferenças em termos do crescimento do número de produtos. 
A análise do número de produtos qualificados nos estratos mais altos do antigo e do novo Sistema Qualis indica que houve expressivo crescimento dos produtos qualificados nesses níveis, nos quatro Programas analisados na pesquisa. Isto nos permite afirmar que houve um crescimento quantitativo e qualitativo da produção bibliográfica desses Programas.

Diante dos dados apresentados sobre os discentes e sobre a produção intelectual dos docentes permanentes podemos inferir que as estratégias adotadas pelos Programas em relação aos alunos e aos professores no contexto da prática tiveram efeitos positivos sobre os critérios de avaliação valorizados pela Capes.

As exigências estabelecidas em relação ao credenciamento de docentes permanentes, assim como em relação ao processo seletivo e às exigências no prazo de titulação dos discentes reverteram em uma maior eficiência dos Programas, que aumentaram a proporção discente/docente, diminuíram os prazos de formação e incrementaram a produção bibliográfica em termos quantitativos e qualitativos.

Esse panorama contribuiu para a evolução positiva das notas dos quatro Programas na Avaliação da Capes. O crescimento das notas, por sua vez, teve efeitos materiais e simbólicos positivos, mas foi realizado à custa de um aumento significativo das demandas sobre os coordenadores, como será visto no próximo tópico.

\section{2.}

\section{Efeitos materiais e simbólicos e o aumento das demandas de trabalho}

O aumento dos recursos financeiros foi mencionado por todos os coordenadores entrevistados como uma consequência da conquista da "excelência" na Avaliação da Capes. Esse efeito material, entretanto, não foi percebido de imediato. De fato, o Programa de Excelência Acadêmica (Proex), que teve início em 2006, prevê o repasse diferenciado de recursos a programas que tenham obtido conceito 6 ou 7 em duas avaliações consecutivas da Capes, a partir da segunda avaliação com essas notas: 
Art. $2^{\circ}$ O programa de pós-graduação stricto sensu participante do PROEX deverá:

I - ter obtido conceito 6 ou 7 em duas avaliações consecutivas da CAPES $;{ }^{70}$

Em algum dos programas houve uma decepção no primeiro contato com os recursos, mas, aos poucos, os coordenadores foram percebendo que a diferença estava nos demais recursos do Proex que vão sendo liberados, e também no valor simbólico representado pelo reconhecimento da excelência do programa. Com esse novo status, os professores e alunos do programa conseguem, entre outros benefícios, a aprovação de projetos e bolsas com mais facilidade. Além disso, os programas conseguem maior autonomia financeira, pois os recursos passam a ser gerenciados pelos seus coordenadores, o que diminui consideravelmente os tramites administrativos para aprovação de despesas. Os depoimentos abaixo ilustram bem a situação:

Nossa! A gente queria dar bolsa para os alunos. Quando a gente contabilizou [a nova dotação de recursos] deu nove bolsas a mais, uma bolsa por linha. e então, isso nos deu "um banho de água fria”. Porque quando a gente toma uma decisão, não sei se alguém te falou, mas foi decidido em colegiado que a gente queria fazer todo esse investimento para passar de “6” para "7”. Uma decisão de colegiado e que não foi unânime! Tinha gente que achava que nem deveríamos ligar para a Capes [...] E aí todos os que não queriam falavam assim "não valeu a pena!" [...] Só que aí esse dinheiro vai chegando, porque ele não vem todo junto. Daí a pouco eu sei que chagavam mais 170 mil, daí a pouco mais 100 mil. Então aí a gente pensou: "Ôpa, as coisas melhoram!" E, realmente, as bolsas foram aumentando, e tudo fica facilitado. É realmente uma avaliação atrelada a um financiamento. Claramente, depois do "7" eu vi isso com muita clareza. Porque aí tem outras coisas que não são diretas, mas é assim: todos os nossos alunos que pediram bolsa sanduíche (100\%) recebem! Todos os alunos que pediram bolsa de pós-doutorado para vir para cá, recebem! Então "você" vai multiplicando. Todos os alunos do Programa que pedem auxílio do CNPq ou Capes ou Fapemig ${ }^{71}$ ou para congressos internacionais, conseguem. Então ele vai se multiplicando tanto. (Coordenador B - UFMG).

Quando "você” passa a entrar no Proex, de início, inclusive, o melhor não é a quantidade de dinheiro, porque de início o dinheiro quase não entra. Mas aumenta a flexibilidade de utilização desse dinheiro, porque "você" deixa de ter o financiamento mediado pela Universidade e passa a ter "na mão" do coordenador. "Felicidade mor" para os professores e para os alunos, e um "terror" para a vida do coordenador.[...] O coordenador passa a gerenciar o dinheiro de todo mundo, mas passa a ser muito mais fácil. Se você fosse aluna do Programa, você viajaria, voltaria, traria lá o seu certificado de que você apresentou o seu trabalho e eu te daria um cheque, de imediato. (Coordenador B - Uerj).

\footnotetext{
${ }^{70}$ Portaria n ${ }^{\circ} 34$, de 30 de maio de 2006.

${ }^{71}$ Fapemig - Fundação de Amparo à Pesquisa do Estado de Minas Gerais.
} 


\begin{abstract}
Autonomia financeira: a maior consequência disso é uma sustentabilidade do Programa, com o Proex. E menos vulnerabilidade em relação à política da instituição. [...] O primeiro ano do Proex basicamente o recurso todo foi para bolsa. Como isso, vai aumentando proporcionalmente, num segundo ano a gente teve muito mais margem, inclusive com os aditivos, depois, para estimular os alunos a participarem de congresso. [...] Então, esse recurso significou muito mais condições. (Coordenador B - Unisinos).
\end{abstract}

Tão importante quanto os ganhos financeiros advindos da conquista da excelência são os ganhos simbólicos. Em primeiro lugar, os coordenadores mencionam que ser um Programa de Excelência significou um maior reconhecimento dentro das próprias instituições, implicando em mudanças significativas em relação à autonomia e às condições de trabalho. Além disso, houve um maior reconhecimento da comunidade acadêmica e dos órgãos de fomento, o que acaba por aumentar os recursos auferidos pelos programas que se encontram nessa condição:

Foi um susto tão grande quando a gente soube que fomos de 4 para 6 , que nós ficamos embasbacados, literalmente, porque assim: "nós somos excelentes!" Foi algo que nos assombrou muito internamente. E esse internamente gerou um impacto muito grande porque a Área de Educação, como em geral das humanas, ela é tida como Área mais [...]. Aí, eu olho pela questão de gênero, "aquele Programa ali com aquela mulher lá" [...], e quando virou para 6 , e que mais ou menos o pessoal sabe que tem um rigor para chegar nesse 6 , aí meio que eles (eles eu digo a Universidade como um todo e a própria direção) começaram a prestar atenção. Então, tem alguma coisa aí. E eles nos deixaram bastante livres. "Então se eles são bons [...] Vamos ver se são bons!" Ganhamos certa autonomia sim, isso sempre pesou nas nossas discussões internas, mas isso também não queria dizer que nós tínhamos o tapete vermelho. (Coordenador A - Unisinos)

Em outras Universidades isso pode não ser significativo, mas na Uerj nós passamos a ser o único Programa“7”. Nós somos o primeiro e o único Programa "7" da Uerj, porque a Uerj tem uma história de pósgraduação muito recente. Não nos abriu "as portas do paraíso", [...] mas, às vezes, nos abre algumas portas. Nas agências, eu, individualmente, não percebi essa diferença porque sou pesquisadora 1 do $\mathrm{CNPq}$ (já tem um tempinho, não muito tempo, mas já faz algum tempo). Mas para um professor, de repente, que não é pesquisador 1 , isso pode ter pesado na avaliação de alguns projetos. Tipo: "ôpa, a agência recebeu, o avaliador recebeu, 8 professores do Programa 7". Suponho que, e acredito fortemente que deve ter feito a diferença, para os alunos também. Não aumentou tanto bolsa, mas aumentou bastante a possibilidade da gente financiar aluno para evento, para atividades de pesquisa, abrir bolsa, abrir uma facilidade maior para bolsa sanduiche no exterior. Então, para os alunos foi uma boa diferença. (Coordenador B - Uerj).

Acho que muda o status do Programa dentro da Universidade, a gente pode então contar com um maior reconhecimento dentro da 
Universidade. Acho que essa é a primeira vantagem interna, assim, de saída. (Coordenador A - PUCRS).

Deu uma autoestima? Deu! Quer queiramos, quer não, você passa a ser visto como referencia, então tem [mudança]! Os professores sabem disso, os alunos sabem disso, e você é muito mais demandado. Você vira mesmo uma referencia! (Coordenador B - UFMG).

Outra consequência do reconhecimento é que mais docentes e discentes passam a querer fazer parte do Programa. No longo prazo, isso poderá contribuir com a melhoria da qualidade dos Programas, pois as possibilidades de seleção são ampliadas, tornando possível a escolha de melhores candidatos para preenchimento dos quadros de professores e das vagas pelos alunos:

A gente é uma Universidade privada "paga". Portanto, não tem bolsa para todo mundo. Enfim, não é uma Universidade muito barata. Dentro da região metropolitana, aqui em Porto Alegre, a gente tem outros cursos com uma concorrência significativa. Tem a UFRGS que também tem nota 6 , tem a Unisinos que agora subiu para 7 , tem outros programas em volta. E a gente continua tendo, sei lá, de 12 a 15 candidatos por vaga. [...] Antes eram 10 candidatos por vaga, no máximo. Isso, no máximo, 10 candidatos. E agora isso vem aumentando [...] Uma coisa que eu acho que também objetivamente se coloca é a demanda por candidatos de fora, de fora do estado, de fora do Rio Grande do Sul. (Coordenador C - PUCRS).

Nós passamos a ter uma demanda importante em relação aos estágios para doutorado do Programa. Seja de pesquisadores que vêm de outros estados, seja daqueles que nós induzimos por conta do Programa de pós-doutorado que existe na Faperj. Então, a gente tem um número que nós não tínhamos, tudo muito recente. (Coordenador A - Uerj).

Mas isso aí, sem dúvida, tem custo, porque você tem essa questão da entrada, isso tem um custo. Têm pessoas que entram na comunidade e entram normalmente no Programa, mas têm pessoas que querem entrar e não conseguem. (Coordenador E - UFMG).

Por fim, o efeito da entrada no grupo dos Programas de Excelência e do reconhecimento é também uma maior sobrecarga de trabalho para docentes e coordenadores. Como vimos no tópico anterior, nos últimos triênios, houve redução de tempo de formação, ampliação da proporção entre discentes por docente permanente, aumento da produção qualificada discente, assim como um aumento quantitativo e qualitativo da produção acadêmica docente nos Programas analisados.

Depois do reconhecimento, novas demandas ocorrem, seja para a manutenção dos níveis de produção considerados internacionais, ou ainda, pelo aumento da responsabilidade dos coordenadores em relação aos recursos 


\section{repassados pelo Proex. Os coordenadores mencionam essas questões nos trechos} selecionados abaixo:

E depois que a gente passou para o "6", a gente tinha clareza que muito mais difícil era manter o "6". Porque aí, os quesitos da Capes passaram a balizar muito mais. Porque nós tínhamos também um mote, que eu diria que nos mobilizou, e que a gente mobiliza no grupo até hoje, para autonomia [financeira] do grupo dentro da instituição. Apesar de haver o mesmo contorno de excelência na questão do ensino, a questão financeira é fundamental. (Coordenador B Unisinos)

A Capes é importante do ponto de vista do apoio ao Programa. Aquela coisa do Proap e do Proex. Enfim. Então, você tem uma forma de financiamento que é direta. Isso traz um ônus para a coordenação. Porque a coordenação termina não apenas como gestora das atividades acadêmicas, mas funciona também como gestor financeiro, com um monte de conta pendurada no nome do coordenador do Programa. Uma pequena ["tragédia"], digamos assim! (Coordenador A - Uerj).

\section{Outra demanda decorrente da conquista da excelência é o aumento da procura de outras instituições interessadas em fazer parcerias ou em busca de apoio. Foi possível depreender que há um comprometimento desses profissionais em atender essas demandas:}

A demanda aumentou porque a gente se tornando um Programa "5", e especialmente se tornando um Programa“"6", os outros Programas que precisam crescer começam a nos procurar com mais intensidade, estão querendo fazer parceria, querendo "Dinter", querendo "Procard", querendo "casadinho", querendo outros modelos. Então a demanda para nós cresceu. (Coordenador C - PUCRS).

Eu senti muita diferença nesse triênio com a tal pressão da internacionalização. Mas no 'chão da fábrica', o que isso significa? Fazer contato com a Argentina, conhecer um grupo que eu nunca vi na minha vida, criar um programa e 'ir pra lá e vir pra cá'. Eu nem sonhava há uns seis anos atrás e esse ano já vejo frutos disso, de alunos virem pra cá. Neste programa só os de lá podem vir pra cá, porque nós somos um programa consolidado e eles não. E aí tu ficas pensando 'poxa, mas isso é ruim?' Não, isso é muito bom! Ou seja, é criar essa ideia de que tu podes fazer parceria e ser rede, na medida em que tu consolidas, aí é tu tens mais coisa a aprender! Por exemplo, eu me espelho muito na Federal de Minas, eu acho assim que têm uma sacada, e eles são enormes e conseguem fazer! [...] E eles têm um compromisso com a realidade brasileira que eu fico impressionada. E o trabalho é belíssimo! (Coordenador A - Unisinos)

Por exemplo, eu estava no Maranhão agora. O que eu estava fazendo no Maranhão? Eles me pediram uma ajuda exatamente porque eles estão com muitos problemas e precisavam melhorar o programa. E isso não é só lá. É na UFRGS que pedem, é na Unicamp, em várias. Então, você passa a ser visto. A gente tem que ter cuidado porque passa a ser visto como referencia. E o que a gente pode contar é o que deu certo e o que não deu, o que a gente achou que serve, que ainda serve e o que dá aqui, não significa que vai dar certo em outro contexto. (Coordenador B - UFMG). 
O fato de a maior parte dos entrevistados afirmar que, no âmbito dos seus programas, se desenvolvem projetos coletivos e parcerias com outros programas menos consolidados demonstra que o campo acadêmico está marcado, ao mesmo tempo, pela concorrência e pela atividade coletiva, o que, no limite, indica a possibilidade de lucro para os componentes que trabalham em articulação.

Esse movimento acaba por fortalecer os programas mais e menos consolidados, seus grupos de pesquisa e os docentes das instituições parceiras, e, por conseguinte, o próprio campo acadêmico.

Mais especificamente, a inserção nacional, regional ou internacional do pesquisador de programas consolidados, ou a busca dessa inserção, gera uma maior possibilidade de reconhecimento pessoal e acadêmico na comunidade científica da área, e isto aumenta a probabilidade de distribuição e consumo de sua produção intelectual.

\section{3.}

\section{Considerações sobre os efeitos na perspectiva de Ball e Bourdieu}

Assim como no contexto da prática, é possível analisar os resultados ou efeitos decorrentes das mudanças ocorridas com os Programas no período abarcado pela pesquisa, à luz das categorias de Ball e de Bourdieu. Neste caso, optamos por analisar esses efeitos em conjunto, uma vez que os mesmos dizem respeito, relacionalmente, aos conceitos de performatividade e de campo científico.

Ao analisarmos os dados e depoimentos relativos aos efeitos das mudanças realizadas nos Programas, é possível perceber a associação entre produção acadêmica e ganhos materiais e simbólicos. Os Programas mais produtivos e eficientes, como os que selecionamos nessa pesquisa, recebem a chancela de "Programa de Excelência", obtém mais recursos financeiros da Capes e um maior reconhecimento da comunidade científica. Essa situação está relacionada à cultura da performatividade:

\footnotetext{
A instalação da nova cultura da performatividade competitiva envolve o uso de uma combinação de devolução, metas e incentivos para se efectuar o replanejamento institucional. Isto advém não só de uma
} 
teoria económica recente como também de várias práticas industriais [...]. (BALL, 2002, p. 8).

A cultura avaliativa instalada na pós-graduação envolve o estabelecimento de "metas" a serem alcançadas como, por exemplo, um número mínimo de produtos qualificados por docente no triênio, tempo máximo de titulação dos alunos, proporção adequada entre docentes e discentes etc. A “devolução" sobre o desempenho dos Programas em relação às metas propostas é materializada pelas fichas e relatórios de avaliação dos Programas, que apontam os acertos e os pontos a serem aperfeiçoados, analisam sua performance em cada um dos diferentes quesitos e itens e sintetizam os diversos aspectos observados em uma nota estabelecida na avaliação. Neste caso, a capacidade técnica dos programas de pós-graduação é reconhecida e legitimada pela Avaliação da Capes, que define hierarquias entre os programas, através das notas. Essa legitimação e esse reconhecimento influenciam a distribuição dos capitais no campo.

Segundo Bourdieu (1983a, p.130):

A autoridade científica é, pois, uma espécie particular de capital que pode ser acumulado, transmitido e até mesmo, em certas condições, reconvertido em outras espécies.

Para o autor, a posse de capital científico tende a favorecer a aquisição de capital suplementar, num processo contínuo de acumulação. Nessa perspectiva, podemos argumentar que programas considerados "de excelência" tem aumentada sua "autoridade científica" no campo, o que gera para eles lucros materiais e também simbólicos.

Com efeito, esses programas passam a receber mais recursos da Capes e também de outras fontes de fomento, que aprovam seus projetos e pedidos com mais facilidade. Além disso, a comunidade acadêmica passa a reconhecer a qualidade do programa, que é Proex. As instituições de origem dos programas e também aquelas que com eles se relacionam passam a tratá-los com mais deferência. Professores e alunos querem fazer parte de seus quadros e os profissionais de outros programas querem conhecer suas experiências visando ao seu aperfeiçoamento.

Por fim, não poderíamos deixar de mencionar, que esta pesquisa também é parte do reconhecimento dos Programas de Excelência, na medida em que os 
elegeu como referencia para identificar estratégias de gestão que podem ter contribuído para o avanço das suas notas na Avaliação da Capes.

Outra questão que fica evidenciada no contexto de resultados ou efeitos é a da "visibilidade". Para Ball (2005), a performatividade é uma luta pela visibilidade, pois é o efeito generalizado da visibilidade e da avaliação que penetra em nossa maneira de pensar a respeito de nossa prática e produz a performatividade. A visibilidade está relacionada a uma preocupação dos indivíduos ou instituições de se distinguirem dos demais:

\begin{abstract}
No âmbito de uma matriz de avaliações, comparações e incentivos relacionados com o desempenho, os indivíduos e as organizações farão o que for necessário para se distinguir ou sobreviver. [...] A performatividade atinge profundamente a percepção do eu e de nosso próprio valor. Coloca em pauta uma dimensão emocional, apesar da aparência de racionalidade e objetividade. Assim, nossas respostas ao fluxo de informações a respeito do desempenho podem engendrar nos indivíduos sentimentos de orgulho, culpa, vergonha e inveja. (BALL, p.549-550).
\end{abstract}

Foi possível perceber, na fala dos entrevistados, especialmente sentimentos de orgulho por fazerem parte de um Programa de Excelência. Sentimentos que ficam evidenciados em trechos como: "ficamos embasbacados" (p.196), "somos excelentes" (p.196), “o primeiro e o único Programa 7” (p.197), “deu uma autoestima" (p.197). Os agentes interpretam a chancela dada ao programa como uma chancela de excelência dada a eles próprios. Nesse sentido, é como se fazer parte de um Programa de Excelência tornasse as pessoas "excelentes". Além disso, também foi possível perceber uma preocupação com a imagem do programa perante a comunidade acadêmica, aos outros programas, já que o programa considerado de excelência passa a ser visto como uma referencia.

Bourdieu (1983a) também aborda a questão da visibilidade dentro do campo científico, como um meio de se conseguir autoridade científica. Café (2007) resume assim este ponto:

A autoridade científica é compreendida como capacidade de falar e agir legitimamente, posição esta que é outorgada socialmente a um agente determinado. Esta autoridade está relacionada, diretamente, ao conhecimento da posição que o agente ocupa nas hierarquias instituídas. Todas as práticas dentro deste campo estão orientadas para aquisição de autoridade científica [...] o que acaba determinando as escolhas quanto às disciplinas, métodos e instrumentos de pesquisas que lhes deem maior visibilidade e possam contribuir para a obtenção do reconhecimento entre os pares concorrentes. (p. 4). 
O reconhecimento concedido pelos pares concorrentes é marcado e garantido socialmente por todo um conjunto de sinais específicos de consagração. O reconhecimento desses programas também ficou evidenciado nas falas dos entrevistados, quando mencionam que o fato de terem se tornado Programas de Excelência "abriu portas" dentro e fora de suas instituições. A transferência do reconhecimento do programa para os docentes e discentes que o compõem é ainda um efeito da excelência atestada pela Capes: professores e alunos desses programas são mais respeitados pela comunidade acadêmica e pelas agências de fomento à pesquisa e de concessão de bolsas. Com isso, ocorre o que Bourdieu prevê em relação ao conceito de visibility, um acúmulo de uma espécie particular de capital social: o capital de autoridade. Assim:

$$
\begin{aligned}
& \text { [...] acumular capital é fazer um "nome", um nome próprio, um nome } \\
& \text { conhecido e reconhecido, marca que distingue imediatamente seu } \\
& \text { portador, arrancando-o como forma visível do fundo indiferenciado, } \\
& \text { despercebido, obscuro, no qual se perde o homem comum. } \\
& \text { (BOURDIEU, 1983a, p. 132). }
\end{aligned}
$$

Esses programas, e em consequência as pessoas que fazem parte deles (docentes e discentes), se destacam no campo acadêmico, seus trabalhos e projetos são mais bem apreciados e aprovados com maior facilidade, os produtos, em termos de artigos, capítulos de livros etc., tem melhor divulgação. Nos termos de Bourdieu:

[...] a visibilidade de um nome numa série é função, em primeiro lugar, de sua "visibilidade relativa", definida pelo grau que ele ocupa na série e, em segundo lugar, de sua "visibilidade intrínseca", que resulta do fato de que, já conhecido, ele é mais facilmente reconhecido e retido (um dos mecanismos que fazem com que, também aqui, o capital leve ao capital). (1983a, p.133).

No caso dos programas pesquisados, a visibilidade é alta, pois na hierarquia do campo da pós-graduação em educação, eles estão no topo da classificação da Capes. Sua visibilidade intrínseca decorre dessa visibilidade relativa, na medida em que esses programas entram e conseguem se manter no grupo dos Programas de Excelência. Dessa forma, eles ingressam em um círculo virtuoso que envolve uma melhor avaliação, melhores condições materiais, mais recursos financeiros, melhores possibilidades de seleção de docentes e discentes, mais e melhores produtos, o que, por sua vez, resulta na obtenção das melhores notas na Avaliação da Capes. 
Evidentemente, esse não é um status garantido. Por diferentes motivos, um programa que se tornou de excelência pode vir a deixar de sê-lo, como já ocorreu com outros programas, em outras instituições ${ }^{72}$. Todavia, parece haver maiores incentivos e facilidades para os programas que "chegaram lá" do que para aqueles que estão na disputa pelo ingresso no grupo de Programas de Excelência.

De acordo com Bourdieu (1983a), a busca pela visibilidade é uma estratégia política orientada para a maximização dos lucros científicos, embora, muitas vezes, não seja plenamente calculada ou consciente. Sob essa perspectiva, a análise dos dados desses programas evidencia o crescimento quantitativo e qualitativo da produção ao longo da última década. Embora nem todos esses produtos tenham sido produzidos com a intenção direta de se conseguir a excelência, é bastante plausível afirmar que o aumento da produção acadêmica e a melhora de seus indicadores de formação é parte de uma estratégia adotada pelos programas para ascender na Avaliação da Capes.

Desse crescimento da produção e melhoria dos resultados, que não foi acompanhado de forma proporcional pelo crescimento do corpo docente, derivou uma sobrecarga de trabalho para os programas. Para alcançar esses resultados, os docentes tiveram que produzir mais e assumir novas atribuições e demandas decorrentes do fato de terem se tornado Programas de Excelência, que se refletem numa maior "auto" cobrança, no aumento de docentes, pesquisadores e instituições propondo parcerias, no número maior de tarefas designadas aos coordenadores, como a administração dos recursos do Proex e a divulgação da experiência em outros programas, por exemplo. Nesse contexto, os profissionais, que trabalham em programas de pós-graduação considerados de excelência, além de terem que assumir as demandas acadêmicas e administrativas de praxe também tem de arcar com novas e maiores responsabilidades, decorrentes da sua posição no campo educacional.

Moreira (2009) retrata bem a situação, em relação aos docentes dos cursos de pós-graduação, particularmente aqueles que fazem parte de programas com os conceitos mais altos conferidos pela Capes, ao afirmar que:

\footnotetext{
${ }^{72} \mathrm{Na}$ Área da Educação temos os seguintes exemplos de programas que entraram e saíram do grupo dos Programas de Excelência: o Programa da Universidade Federal Fluminense (UFF), o Programa da Universidade Federal de São Carlos (Ufscar), o Programa da Universidade Federal do Rio Grande do Sul (UFRGS) e o Programa da Universidade de São Paulo (USP). Estes dois últimos Programas, por sua vez, voltaram para o grupo dos Programas de Excelência em novas avaliações.
} 
A constante pressão, decorrente dos critérios da Avaliação da Capes, atormenta os docentes da pós-graduação, incitando-os a serem produtivos (em termos quantitativos) e a publicarem, com frequência em veículos qualificados, os produtos das pesquisas realizadas. Quanto maior o conceito do programa em que se atua, maior deve ser o número de publicações: há que se atingi-lo, para que não se reduza a nota alcançada no último triênio. Qualquer diminuição acarreta substantiva perda de prestígio e de recursos na alucinante corrida por se chegar "ao topo", por se atingir o tão invejado "padrão internacional". (Ibid., p. 35).

Essa situação é prevista por Ball (2005), quando trata do contexto da performatividade e da necessidade de se atingir padrões cada vez mais altos de desempenho:

Há um fluxo de novas necessidades, expectativas e indicadores que nos obriga a prestar contas continuamente e a ser constantemente avaliados. Tornamo-nos ontologicamente inseguros: sem saber se estamos fazendo o suficiente, fazendo a coisa certa, fazendo tanto quanto os outros, fazendo tão bem quanto os outros, numa busca constante de aperfeiçoamento, de ser melhor, ser excelente, de uma outra maneira de tornar-se ou de esforçar-se para ser o melhor - a infindável procura da perfeição. (Ibid., p. 549).

Embora em seus depoimentos esses coordenadores não expressem diretamente essa competitividade, ou a preocupação exclusiva com a chancela da Capes, os dados e as situações relatadas corroboram essa ideia. Mesmo sobrecarregados, esses profissionais assumem cada vez mais tarefas, se envolvem em cada vez mais parcerias, produzem cada vez mais em periódicos de maior qualidade, orientam mais alunos, titulando-os em menos tempo. 


\section{8.}

\section{Considerações conclusivas do estudo}

Ao chegarmos ao final desse trabalho, podemos fazer algumas considerações em relação à pesquisa e às questões que nos propusemos discutir, com vistas a contribuir para o desenvolvimento do tema da gestão de programas de pós-graduação.

Nossa proposta foi investigar quatro Programas de Excelência da Área da Educação que apresentaram aumento de duas notas ao longo das avaliações trienais de 2001 a 2010 (PUCRS, Uerj, UFMG, Unisinos), a fim de identificarmos possíveis estratégias adotadas pelos seus coordenadores, que possam ter contribuído para o avanço dos resultados. Para atingirmos esse objetivo, realizamos estudos de caso nos quatro programas que se encontravam nessa situação, utilizando referencias teóricas de Stephen Ball, relativas ao ciclo de políticas e ao conceito de performatividade, e de Pierre Bourdieu, relativas ao conceito de campo científico.

Nosso pressuposto inicial era de que o trabalho de gestão teria tido importância significativa para que os programas selecionados apresentassem esse avanço expressivo dos resultados, o que se confirmou nas entrevistas.

A investigação nos permitiu identificar estratégias comuns às quatro experiências, e também relações entre as questões que emergiram dos contextos analisados com mudanças positivas nos indicadores que compõem a Avaliação da Capes, além de possibilitar o estabelecimento de um diálogo com questões presentes na literatura acadêmica.

A análise das entrevistas realizadas e do material coletado nos levou à elaboração de algumas conclusões. Em primeiro lugar, foi possível perceber que os programas analisados buscaram atingir um alto nível de qualidade acadêmica. Embora inicialmente não tivessem como horizonte se tornar um "Programa de Excelência" na Avaliação da Capes, esses programas se planejaram e se empenharam, por meio de diferentes estratégias, para atingir critérios de qualidade que estão alinhados com os critérios do sistema de avaliação da pós-graduação.

A busca docente de padrões altos de qualidade, de um lado, e a atuação do Estado como indutor de políticas do outro; revela traços da cultura da 
performatividade, de Ball (2002; 2004; 2005), que envolve aspectos como comparação, padronização, aferição de resultados e recompensas, que encontra solo fértil no terreno da pós-graduação brasileira.

Além disso, foi possível perceber que, no contexto dos programas analisados e da Política de Pós-Graduação que os orienta, estão presentes vários elementos do conceito de campo científico,de Pierre Bourdieu (1983a), segundo o qual os agentes fazem parte de uma hierarquia social que pauta fortemente as práticas e a luta concorrencial em que está em jogo o monopólio da competência científica.

Os agentes são os coordenadores e docentes, que ficam melhor ou pior posicionados nas hierarquias do campo educacional e no interior dos seus programas de pós-graduação, em função de sua antiguidade e experiência, do conhecimento e do reconhecimento obtido pelas suas pesquisas e produtos bibliográficos e, também, dos cargos institucionais que ocupam, o que corresponde a diferentes volumes de capital científico e de capital institucional. Suas ações são guiadas em boa medida pelo capital científico e institucional que possuem, o que os leva a agir por meio de "estratégias de conservação", no caso dos seniores, ou "estratégias de sucessão"ou "subversão", no caso dos novatos. Eles atuam visando ao reconhecimento de seus próprios pares tanto nas hierarquias internas do Programa que coordenam como nas hierarquias externas no campo da pós-graduação decorrentes, em boa medida, da Política de Avaliação da Capes.

No caso dos coordenadores dos programas analisados, ficaram em evidência as estratégias de conservação, já que esses agentes possuem estão em geral bem posicionados na Área da Educação, como consequência das posições anteriormente conquistadas no campo acadêmico e, principalmente, do fato de pertencerem a Programas de Excelência. Dessa forma, para garantir a posição de destaque no campo, eles reafirmam e legitimam o processo de Avaliação da Capes, assim como os parâmetros de produção científica estabelecidos.

Os coordenadores dos programas estudados reconhecem, em seus depoimentos, o valor do processo de Avaliação da Capes para o desenvolvimento da pós-graduação no país. A maior parte deles considera positivo o sistema de avaliação vigente, atribuindo-lhe papel indutor importante da qualidade atual da 
pós-graduação brasileira, que favorece o desenvolvimento da pesquisa e proporciona um uso mais racional e adequado do dinheiro público.

Em geral, esses coordenadores também se posicionam a favor da adoção dos parâmetros que prevalecem nas Ciências Exatas e Naturais, vistas como áreas com mais tradição no campo científico, para referenciar as orientações da política de pós-graduação e de avaliação das Áreas das Ciências Humanas e Sociais pela Capes, sem que isso envolva, a seu juízo, a padronização de critérios nem a homogeneização de resultados e produtos da pós-graduação. Relativizam, ainda, a existência de um produtivismo na Área da Educação, considerando ser baixa, ou no mínimo relativamente fácil de atingir, mediante estratégias próprias que eles mesmos adotaram nos programas que coordenam, a exigência de produção científica estipulada para os docentes que atuam em programas da Área.

A pesquisa, entretanto, identificou a presença de tensões no campo acadêmico em relação à Avaliação da Capes. Algumas críticas dos coordenadores, quando expostas, se concentram no tema do financiamento dos programas, e são dirigidas mais especificamente à associação entre mérito e fomento que pauta a distribuição de recursos pelas áreas de conhecimento e pelos programas, o que acabaria por favorecer determinados campos de conhecimento e determinados programas mais estruturados, em detrimento de outros.

De fato, como previsto por Ball (2004), a cultura da performatividade age por meio de um sistema de incentivos, recompensas e sanções baseadas mais na competitividade que na solidariedade. Nesse sistema são almejados e celebrados compromissos com o empreendimento, a competição e a excelência; e inibidos e deslegitimados outros relativos à justiça social, equidade e tolerância.

A utilização do Sistema Qualis para aferir a qualidade das publicações também não é consensual. Parte dos coordenadores considera este sistema hierarquizante e restritivo, em razão da limitada quantidade de periódicos e de publicações comportadas pelos seus estratos mais elevados. Outra parte dos coordenadores reconhece a dificuldade de determinar a qualidade da produção científica do campo educacional, e considera o Sistema Qualis como um caminho adequado nessa direção. A avaliação de livros, por sua vez, é reconhecida pelos coordenadores como uma das conquistas importantes da Área da Educação.

As vozes mais discordantes em relação à Política de Pós-graduação coordenada pela Capes emergiram claramente dos representantes de entidades da 
Área, notadamente da Anped e do Forpred. Embora os entrevistados reconheçam a importância de se avaliar a qualidade da pós-graduação como forma de promover a necessária, e ainda não concretizada, distribuição mais adequada dos recursos públicos tecem, ao mesmo tempo, críticas ao poder excessivo da Capes e de seus diretores na definição e elaboração da política de pós-graduação, que se faz acompanhar da exclusão da comunidade acadêmica deste processo.

Além disso, revelam que há um luta por reconhecimento dessas associações perante a Capes, denunciando serem deliberadamente ignorados pela agência, o que envolve o enfraquecimento da atuação das instâncias coletivas da pós-graduação.

Em razão disso, a atuação desses representantes perante a Capes é guiada preponderantemente por estratégias de subversão, o que envolve audiências com o ministro da Educação e denúncias como as realizadas nas entrevistas que concederam a esta pesquisa. Nessa perspectiva, a relação entre a Capes e os representantes das associações vinculadas diretamente à pós-graduação se diferencia, em grau e natureza, das que mantém com a agência os coordenadores dos cursos de excelência, que têm seus programas e espaços institucionais reconhecidos, o que os leva a adotar, preponderantemente, estratégias de conservação.

No entanto, os debates que se travam no interior dessas associações em torno da Política de Pós-Graduação e do poder da Capes não podem ser identificados como desfavoráveis ao campo educacional. São eles que permitem o avanço da luta por espaços nesse campo, uma vez que o resultado dessas lutas e debates aparece na produção e na distribuição de discursos que contribuem para a consolidação da identidade do campo. Nesse domínio, segundo Bourdieu, enquanto houver luta, haverá história, isto é, esperança.

Nos estudos de caso, podemos perceber que, nas lutas que se travam com o objetivo de conservar a posição de excelência atingida pelos programas nas hierarquias do campo acadêmico, se engendram as estratégias dos seus coordenadores e docentes que agem de acordo com a Política de Avaliação da Capes, visando o atendimento dos seus critérios.

Em particular, as entrevistas revelaram a adoção de estratégias de conservação comuns aos programas investigados em relação, especialmente, ao corpo docente, ao corpo discente e à gestão coletiva. 
A principal estratégia relacionada aos professores é a implantação de uma política de credenciamento docente, enquanto acompanhamento sistemático de sua atuação e produção. Nos quatro casos estudados, trata-se do estabelecimento de critérios claros e exigentes para a entrada (credenciamento) e permanência dos docentes nos programas (recredenciamento). De acordo com essa política, que não deixa de refletir a necessidade de controle imposta pela performatividade, passouse a fazer um acompanhamento sistemático da produção bibliográfica dos docentes com vistas à permanência deles no programa, que é realizado pelo coordenador ou por uma comissão especificamente reunida para esse fim.

Em consequência, os programas passaram a adotar também o descredenciamento como uma alternativa no caso de docentes que não conseguem atingir as metas de produção acadêmica estipuladas, o que chegou a ocorrer em três dos quatro programas (PUCRS, UFMG e Unisinos). No caso das Universidades privadas, o descredenciamento causa ainda mais impacto na vida do programa e dos docentes, pois implica na demissão do profissional. $\mathrm{O}$ descredenciamento de docentes, nesse sentido, se mostra como um dos pontos mais emblemáticos da performatividade presente na pós-graduação, na medida em que reflete uma nova ética baseada no interesse institucional, no pragmatismo e no valor performativo dos indivíduos.

Outro ponto de convergência entre os programas e entre suas estratégias de tradução da política de pós-graduação diz respeito ao corpo discente. Trata-se do aprimoramento do processo seletivo de candidatos ao mestrado ou doutorado, na perspectiva do estabelecimento de um vínculo estreito entre o projeto do candidato e a pesquisa do professor. Outras estratégias dizem respeito ao incentivo à publicação, por meio de atividades específicas, de desenvolvimento da escrita acadêmica por meio de disciplinas e oficinas, de monitoramento da produção por meio de comissões de acompanhamento, ou da exigência de publicação como requisito parcial para a integralização do doutorado, além de pautar por um maior rigor o tempo de titulação dos alunos.

Tanto essas estratégias direcionadas ao corpo docente quanto as direcionadas ao corpo discente estão em consonância com os parâmetros de Avaliação da Capes.

Por sua vez, as estratégias de gestão coletiva emergiram como uma categoria nativa dos programas analisados, materializando a forma como os 
coordenadores se articularam para enfrentar os desafios postos pelo trabalho de gestão. A gestão coletiva diz respeito a experiências de gestão mais compartilhadas, que fazem com que os coordenadores desses programas se sintam mais seguros e menos sozinhos na realização das tarefas inerentes ao cargo. Tratase de estratégias que descentralizam tarefas e funções de gestão da figura do coordenador, que passa a ser apoiado por um núcleo docente forte de tomada de decisão, por colegiados atuantes e, ainda, por comissões permanentes e temporárias de apoio a tarefas específicas. No contexto da prática de cada programa estudado, as experiências de gestão compartilhada dos programas adquirem feições singulares, mas todas elas indicam que as estratégias utilizadas pelos agentes podem se constituir não apenas a partir de ações de concorrência e competição, mas também de ações de cooperação com vistas ao alcance de metas coletivas.

Além da gestão coletiva, a análise das dimensões contextuais pesquisadas revelou outras estratégias de gestão adotadas por esses profissionais, notadamente em relação à forma de provimento ao cargo de coordenador e à sua preparação para atuar nele.

A maior parte dos programas (Uerj, PUCRS e Unisinos) adapta o que está previsto nos seus regulamentos para que os coordenadores sejam escolhidos por pessoas de influencia, que se articulam em busca de um nome que consideram mais adequado. Após esse movimento e o convencimento do "escolhido", o processo de ocupação do cargo é avalizado por procedimentos oficiais, tipicamente eleição ou indicação.

Outra estratégia relacionada à gestão é a formação dos novos coordenadores por meio do compartilhamento de experiências administrativas prévias. Os professores que ocupam o cargo de coordenador, em geral, participaram previamente de outras instancias coletivas de gestão, em âmbitos como o colegiado e as comissões de apoio. Esta estratégia pode repousar, por um lado, no desejo de ajudar os outros componentes do quadro docente a aprender mais, a se integrar na gestão do Programa, especialmente quando os coordenadores são novatos. Embora essa não seja uma ação totalmente consciente, há, por outro lado, o desejo de a coordenação se destacar internamente, e de o Programa ter uma repercussão externa positiva na avaliação da Capes e nas hierarquias do campo educacional. 
As estratégias de gestão coletiva, de indicação do coordenador por pessoas de influencia e de preparação dos docentes para atuarem no cargo, em conjunto, nos permitem afirmar que o trabalho de gestão é valorizado e é considerado estratégico nos quatro Programas de Excelência pesquisados.

Esses achados vão ao encontro do pressuposto inicial da pesquisa, segundo o qual o trabalho de gestão contribuiu para o avanço dos resultados nas experiências pesquisadas. No entanto, se acreditávamos no papel da gestão na conquista da excelência, e a maior cobrança do corpo discente e docente eram, em parte, previsíveis por estarem pautadas pelas exigências da Avaliação da Capes, as estratégias relativas à gestão coletiva dos programas nos surpreenderam.

Do ponto de vista dos resultados, ficou claro, para nós, que as ações desses programas, tanto em relação ao corpo discente e docente como à gestão, se relacionam positivamente com os resultados alcançados pelos programas estudados em termos dos seus indicadores e, consequentemente, da nota obtida no sistema de avaliação da pós-graduação.

Ao analisarmos o desempenho dos programas nos pontos mais valorizados da Avaliação da Capes (Corpo Discente, Teses e Dissertações; e Produção Intelectual), a partir de dados obtidos nos Cadernos de Indicadores, foi possível perceber que houve melhora na maioria deles. Em linhas gerais, as mudanças nos indicadores estão sintonizadas com aspectos valorizados pela Capes, como o aumento no número de doutores titulados, a diminuição do tempo de titulação, o incremento da produção qualificada discente, e especialmente, da produção dos docentes permanentes nos diferentes tipos de publicação considerados (artigos, livros e capítulos), assim como sua divulgação em veículos de circulação internacional.

Os resultados alcançados indicam que as estratégias relativas ao corpo docente (política de credenciamento) e corpo discente (pesquisa vinculada, publicação e prazo) influenciaram positivamente os indicadores desses programas.

Trata-se de estratégias que contribuíram para a melhoria dos indicadores e para a mudança nas notas dos programas na avaliação da Capes, levando-os a integrar o grupo dos Programas de Excelência na década analisada. Desse posicionamento no campo acadêmico resultaram benefícios financeiros e simbólicos que, num círculo virtuoso, contribuíram para a legitimação e consolidação e reconhecimento da sua excelência. 
Os programas foram beneficiados, de forma direta e indireta, em razão da chancela de excelência conquistada junto a Capes. De forma direta, pelos benefícios decorrentes do volume maior de recursos de capital, custeio e bolsas de estudo que os programas passaram a receber pelo fato de fazerem parte do Proex. De forma indireta, os benefícios se expressaram na aprovação com maior facilidade de projetos e bolsas em outras agências de fomento.

Essa chancela também trouxe lucros simbólicos, uma vez que os programas viram aumentada sua "autoridade científica" perante a comunidade acadêmica, que se manifesta segundo princípios de hierarquização interna e externa. A hierarquização interna se expressa na conquista de uma maior respeitabilidade e autonomia dos coordenadores e docentes dos programas no âmbito de suas Universidades. Já na hierarquização externa, o critério de êxito é medido pelo reconhecimento associado a um número crescente de docentes e discentes interessados em fazer parte do programa, no aumento das chances de aprovação de produção bibliográfica de seus docentes, no maior reconhecimento por outras agencias de fomento, o que contribui para confirmar e consolidar a posição desses programas no exclusivo grupo daqueles considerados "excelentes".

No entanto, a conquista e a conservação desta posição isto tem seus ônus. Ao longo da década, os docentes desses programas viram seu trabalho e suas responsabilidades aumentarem significativamente, o que se reflete no aumento do número de discentes por docente do programa, na redução dos tempos de titulação de mestres e doutores e no crescimento da produção bibliográfica dos docentes em termos quantitativos e qualitativos. Para essa sobrecarga de trabalho, também contribuiu a ausência de um corpo técnico especializado de apoio às novas e complexas tarefas que a gestão da pós-graduação é chamada a realizar.

Além disso, com a conquista da excelência, os programas passam a ter de manter volumes crescentes de produção em níveis considerados internacionais, a realizar novas parcerias institucionais e projetos de apoio a outros programas, tendo seus coordenadores que se responsabilizar pela administração direta dos recursos financeiros repassados pelo Proex.

O quadro apresentado, comum aos quatro Programas de Excelência analisados pela pesquisa, nos permite observar como a Política de Avaliação coordenada pela Capes (no nível macro) é traduzida no contexto da prática (nível micro). Tal política se baseia em uma avaliação realizada por pares, por meio da 
qual se direciona a pós-graduação brasileira para a pesquisa e a produção científica.

Os sujeitos entrevistados nesta pesquisa foram unanimes em identificar a Capes como um órgão com plena influencia e poder na atual política de pósgraduação, a ponto de se sobrepor ao Ministério da Educação. Embora a avaliação seja feita por pares, o poder dos membros que compõem as comissões de avaliação é limitado, assim como o do próprio coordenador de Área. São os dirigentes centrais da Capes e o CTC os que detêm a capacidade e o controle dos meios para definir a Política de Avaliação.

Os representantes da Anped e do Forpred, assim como o Coordenador de Área da Educação e os coordenadores de programa reconhecem a força política da Capes e percebem a exclusão das associações representativas da pós-graduação do processo de elaboração dos Planos Nacionais de Pós-Graduação, cujas versões mais recentes (2005-2010 e 2010-2020) reafirmam o papel da Capes como órgão de coordenação e regulação da Política de Pós-Graduação no Brasil. Por sua vez, os Documentos de Área são os textos que melhor refletem as soluções de compromisso em torno das lutas travadas, entre a Área da Educação e a Capes, pela definição da Política de Pós-Graduação e de sua avaliação, assim como os que exercem maior influência no cotidiano da gestão dos programas.

A Política de Avaliação da Capes é influenciada por questões presentes em âmbito internacional. Identificamos influências internacionais indiretas na pósgraduação brasileira relacionadas a mudanças ocorridas no cenário político e econômico internacional, principalmente, nas décadas de 1980 e 1990. Essas influências ecoam e são traduzidas no âmbito da elaboração da política dirigida à pós-graduação, marcando presença nos Planos Nacionais de Pós-Graduação, com destaque para a valorização do papel da avaliação como instrumento de gestão educacional, para os investimentos em Ciência, Tecnologia e Inovação para fins de competição econômica e para a internacionalização da pesquisa e da publicação acadêmica.

As análises apresentadas revelam que as estratégias e ações postas em prática para atingir as metas e os objetivos definidos pela política de pósgraduação da Capes, nos programas analisados, são orientadas por interesses subjetivos dos agentes, que atuam de acordo com múltiplas posições no campo acadêmico. Essas posições se relacionam, simultaneamente, ao valor posicional 
conquistado pelos docentes em seus programas, à posição ocupada por seus programas na Área da Educação e, ainda, à posição da própria Área da Educação no âmbito do campo científico e da pós-graduação brasileira.

O contexto analisado permite nos posicionarmos em relação ao tema, apontando que, embora à custa de um maior esforço das equipes que trabalham nos programas, a política de avaliação da Capes, em suas articulações com a cultura da performatividade, foi indutora de lutas concorrenciais no campo científico que contribuíram para colocar a pós-graduação brasileira e, portanto, a pesquisa em algumas áreas de conhecimento a um patamar de qualidade equivalente aos dos principais centros acadêmicos internacionais. $\mathrm{E}$ isso vem acontecendo a custas das crescentes e excessivas demandas e pressões sobre o corpo docente e os gestores dos programas de pós-graduação.

Esta pesquisa nos permitiu desenvolver também o entendimento que a avaliação vem informando a relação entre mérito e fomento presente nas atuais políticas de pós-graduação, que pode levar à estagnação de uma parcela significativa de programas que não chega a contar com o necessário apoio financeiro e técnico para se consolidar. Na outra fase da moeda, está o limite de programas que podem vir a ser avaliados como de excelência, o que na prática significa que apenas um grupo muito restrito pode alcançar esse reconhecimento.

Do ponto de vista da continuidade da pesquisa, percebemos a pertinência e a necessidade de que novos estudos com foco nos programas de pós-graduação em educação sejam desenvolvidos, envolvendo outros sujeitos, para além dos coordenadores de programas e dirigentes da Área de Educação na Capes, da Anped e do Forpred, como foi a opção desta tese.

Uma aposta é menos que uma certeza. Chegados a este ponto, nossa aposta é que a presente pesquisa poderá vir a somar-se a outros esforços que têm sido realizados no âmbito da pós-graduação brasileira no sentido de contribuir para a qualidade da pesquisa e da formação de quadros, a partir e no âmbito da gestão, tema ainda pouco explorado pela literatura acadêmica. 


\section{9.}

\section{Referências bibliográficas}

ANDRIOLO et al. Classificação dos periódicos no Sistema Qualis da Capes - a mudança de critérios é URGENTE! Revista Brasileira de Reumatologia, São Paulo, v. 50, n. 2, p. 107-112, 2010.

ALMEIDA, M. J. Desafios na organização e na Gestão da Universidade. In: ALMEIDA, M. (Org.). A universidade possível: experiências da gestão universitária. São Paulo: Cultura Editores Associados, 2001. p.17-56

Gestão da escola médica: crítica e autocrítica. Revista Brasileira de Educação Médica, Rio de Janeiro, v. 32, n. 2, p. 202-209, 2008.

ANTUNES, R; RIDENTI, M. Operários e estudantes contra a ditadura: 1968 no Brasil. Mediações, v. 12, n. 2, p. 78-89, jul./dez. 2007.

AXT, M. O pesquisador frente à avaliação na pós-graduação: em pauta novos modos de subjetivação. Psicologia \& Sociedade, v. 16, n. 1, p. 69-85, número especial 2004.

BALBACHEVSKY, E. A pós-graduação no Brasil: novos desafios para uma política bem sucedida. In: SCHWARTZMAN, S. M. C. (Org.). Os desafios da educação no Brasil. Rio de Janeiro: Ed. Nova Fronteira, 2005. p. 275-304.

BALL, S. J. Educational reform: a critical and post-structural approach. Buckingham: Open University Press, 1994.

Cidadania global, consumo e política educacional. In: SILVA, L. H. (Org.). A escola cidadã no contexto da globalização. Petrópolis: Vozes, 1998. p. 121-137.

Diretrizes políticas globais e relações políticas locais em educação. Currículo sem Fronteiras, Rio de Janeiro, v. 1, n. 2, p. 99-116, 2001.

Reformar escolas/ reformar professores e os terrores da performatividade. Revista Portuguesa de Educação, Braga, v. 15, n. 2, p. 3-23, 2002. Disponível em: <http://www.redalyc.org/articulo.oa?id=374152

01>. Acesso em: 16 jan. 2014.

Performatividade, privatização e o pós-Estado do bem-estar. Educação \& Sociedade, Campinas, v. 25, n. 89, p. 1105-1126, 2004.

Profissionalismo, gerencialismo e performatividade. Cadernos de Pesquisa, São Paulo, v. 35, n. 126, p. 539-564, set./dez. 2005. 
Sociologia das políticas educacionais e pesquisa crítico-social: uma revisão pessoal das políticas educacionais e da pesquisa em política educacional. Currículo sem Fronteiras, Rio de Janeiro, v. 6, n. 2, p. 10-32, jul./dez. 2006.

; MAGUIRE, M; BRAUN, A. How schools do policy: policy enactments in secondary school. London, Routledge, 2012.

BARROSO, J. O Estado, a educação e a regulação das políticas públicas. Educação \& Sociedade, Campinas, v. 26, n. 92, p. 725-751, especial - Out. 2005.

BASTOS, J. B. Gestão Democrática. Rio de Janeiro: DP\& A: SEPE, 1999.

BOURDIEU, P. Sociologia. ORTIZ, R. (Org.). FLORESTAN, F. (Coord.). São Paulo: Ática, 1983.

Entrevista com Pierre Bourdieu concedida à François Hincker, La Nouvelle Critique, $\mathrm{n}^{\circ}$ 11/112, fevereiro/março de 1978 (extrato). Texto extraído de: BOURDIEU, Pierre. Questões de sociologia. Rio de Janeiro: Marco Zero, 1983, p. 49-53.

. Coisas Ditas. São Paulo: Brasiliense, 1990.

Os usos sociais da ciência: por uma sociologia clínica do campo científico. Tradução de Denice Barbara Catani. São Paulo: Editora UNESP, 2004.

BONAMINO, A. Tempos de avaliação educacional: o SAEB, seus agentes, referências e tendências. Rio de Janeiro: Quartet, 2002.

BOWE, R.; BALL, S.; GOLD, A. Reforming education \& changing schools: case studies in policy sociology. London: Routledge, 1992.

BRANDÃO, Z. Pesquisa em Educação: conversas com pós-graduandos. Rio de Janeiro: Ed. PUC-Rio; São Paulo: Loyola, 2002.

. Operando com conceitos: com e para além de Bourdieu. Educação e Pesquisa, São Paulo, v. 36, n. 1, p. 227-241, 2010.

BRASIL. Lei da Reforma Universitária. Lei $\mathrm{N}^{\circ} 5.540$, de 28 de novembro de 1968. Brasília, 1968.

Presidência da República. Câmara da Reforma do Estado. Plano Diretor da Reforma do Aparelho do Estado. Brasília, 1995.

Grupo de Trabalho Interministerial. Bases para o enfrentamento da crise emergencial das universidades federais e roteiro para a Reforma Universitária brasileira. Brasília, DF, 2003.

Portaria Normativa Interministerial. MCT/MEC $\mathrm{n}^{\circ} 270$, de 22 de maio de 2003. Brasília, DF, 2003. 
Ministério da Educação e Cultura. Conselho Nacional de PósGraduação. I Plano Nacional de Pós-Graduação - 1974. In: BRASIL. Ministério da Educação. Coordenação de Aperfeiçoamento de Pessoal de Nível Superior. Plano Nacional de Pós-Graduação - PNPG 2005/2010. Brasília, DF, 2004.

Ministério da Educação e Cultura. Conselho Nacional de PósGraduação. II Plano Nacional de Pós-Graduação - 1982. In: BRASIL. Ministério da Educação. Coordenação de Aperfeiçoamento de Pessoal de Nível Superior. Plano Nacional de Pós-Graduação - PNPG 2005/2010. Brasília, DF, 2004.

Ministério da Educação e Cultura. Conselho Nacional de PósGraduação. III Plano Nacional de Pós-Graduação - 1985. In: BRASIL. Ministério da Educação. Coordenação de Aperfeiçoamento de Pessoal de Nível Superior. Plano Nacional de Pós-Graduação - PNPG 2005/2010. Brasília, DF, 2004.

Ministério da Educação. Coordenação de Aperfeiçoamento de Pessoal de Nível Superior. Plano Nacional de Pós-Graduação - PNPG 2005/2010. Brasília, DF, 2004.

Vencendo o desafio da aprendizagem nas séries iniciais: a experiência de Sobral/CE. Brasília: INEP, 2005.

Ministério da Educação e Ministério do Planejamento, Orçamento e Gestão. Portaria Normativa Interministerial $-\mathbf{n}^{\mathbf{0}} \mathbf{2 2}$, de 30 de abril de 2007. Brasília, DF, 2007.

Ministério da Educação. Coordenação de Aperfeiçoamento de Pessoal de Nível Superior. Plano Nacional de Pós-Graduação - PNPG 2011/2020. Brasília, DF, 2010.

BRYK, A. S. et al. Charting Chicago School Reform: democratic localism as a lever for change. Westview Press, 1998.

CAFÉ, A. L. P. Enclausuramento das produções do campo acadêmico: habitus e desafios na perspectiva da socialização. Anais do VII CINFORM: Informação, Humanismo e Desenvolvimento Científico e Tecnológico. Salvador: Instituto de Ciência da Informação - UFBA, 2007.

CAPES. Avaliação Trienal 2001 (triênio 1998/2000) - Comissão de Área da Educação, 2001. Disponível em: <http://www.capes.gov.br/images/stories/ download/avaliacao/2000_038_Criterio.pdf>. Acesso em: 17 nov. 2011.

Avaliação Trienal 2004 (triênio 2001/2003) - Comissão de Área da Educação, 2004.

Ministério da Educação. Programa de Excelência Acadêmica - Proex. Portaria n. 034, de 30 de maio 2006. Brasília, DF, 2006.

Avaliação Trienal 2007 (triênio 2004/2006) - Comissão de Área da Educação, 2007. Disponível em: <http://www.capes.gov.br/ images/stories/downl 
oad/avaliacao/CA2007_Educacao.pdf >. Acesso em: 17 nov. 2011.

Roteiro para classificação de livros: avaliação dos programas de pósgraduação. 111 ${ }^{\text {a }}$ Reunião do CTC, Brasília, DF, 2009. Disponível em: $<$ http://www.capes.gov.br/images/stories/download/diversos/RoteiroLivros. pdf $>$. Acesso em: 12 fev. 2014.

Avaliação Trienal 2010 (triênio 2007/2009) - Comissão de Área da Educação, 2010. Disponível em: <http://capes.gov.br/images/stories/download/ avaliacao/EDUCA_19jun10.pdf>. Acesso em: 17 nov. 2011.

Comunicado n. 003/2012 - Área de Educação. Orientações para Novos APCNS - 2012.

Avaliação Trienal 2013 (triênio 2010/2012) - Comissão de Área da Educação, 2013. Disponível em: <https://docs.google.com/viewer?a=v\&pid=sites \&srcid=Y2FwZXMuZ292LmJyfHRyaWVuYWwtMjAxM3xneDo0MmM5NjRjO TAzNmYwOTlm>. Acesso em: 21 jan. 2014.

Relatório de Avaliação Trienal 2013 (triênio 2010-2012) - Comissão de Área da Educação, 2013.

Regulamento para a Avaliação Trienal 2013 (triênio 2010-2012) Comissão de Área da Educação, 2013.

CARIA, T. Da estrutura prática à conjuntura interativa - relendo o esboço de uma teoria da prática de Pierre Bourdieu. Revista Crítica de Ciências Sociais, Coimbra, n. 64, p.135-146, dez. 2002.

CASTILHO, M. L. Gestão do ensino superior: o caso das IES privadas do Distrito Federal. UNIrevista, São Leopoldo , v. 1, n 2, abril. 2006.

CASTRO, A. M. Administração Gerencial: a nova configuração da gestão da educação na América latina. Revista Brasileira de Política e Administração da Educação, Recife, v.24, n.3, p. 389-406, set./dez. 2008

CASTRO, J. A., MENEZES, R. M. A Gestão das Políticas Federais para o Ensino Fundamental nos Anos 90. Revista Em Aberto, Brasília, n. 75, 2002.

CUNHA, L. A. Educação e Desenvolvimento Social no Brasil. Rio de Janeiro: Francisco Alves Editora, $3^{a}$ edição, 1978, 291 p.

Sobre educação e desenvolvimento social no Brasil: crítica e autocrítica. Educação \& Sociedade, Campinas, n. 10, p. 123-131, set. 1981.

Nova reforma do ensino superior: a lógica reconstruída. Cadernos de Pesquisa, São Paulo, n. 101, p. 20-49, jul. 1997. 
Desenvolvimento desigual e combinado no ensino superior - Estado e mercado. Educação \& Sociedade, Campinas, v. 25, n. 88, p. 795-817, especial out. 2004.

CUNHA, M. I. da. Docência na universidade, cultura e avaliação institucional: saberes silenciados em questão. Revista Brasileira de Educação, Rio de Janeiro, v. 11, n. 32, p. 258-271. 2006.

CURY, C. R. J. A propósito de educação e desenvolvimento social no Brasil. Educação \& Sociedade, Campinas, n. 9, p. 155-163, set. 1981.

Quadragésimo Ano do Parecer CFE no 977/65. Revista Brasileira de Educação, Rio de Janeiro, n. 30, p. 7-20, dez. 2005.

O debate sobre a pesquisa e a avaliação da pós-graduação em educação. Revista Brasileira de Educação, Rio de Janeiro, v. 15 n. 43, jan./abr. 2010.

DARLI, V. R.; MENEGHEL, S. M. Caminhos Percorridos pelo Ensino Médio. IX CONGRESSO NACIONAL DE EDUCAÇÃO - EDUCERE, Curitiba, 2009.

ERICHSEN, H. U. Tendências europeias na graduação e na garantia da qualidade. Sociologias, Porto Alegre, n. 17, p. 22-49, jan./jun. 2007.

FERNANDES, M. S.; FERNANDES, C. F. GOLDIM, J. R. Autoria, direitos autorais e produção científica: aspectos éticos e legais. Revista HCPA, Porto Alegre, v. 28, n. 1, p. 26-32, 2008.

FERRARO, A. R. A ANPEd, a pós-graduação, a pesquisa e a veiculação da produção intelectual na Área da Educação. Revista Brasileira de Educação, Rio de Janeiro, n. 30, p. 47-69, 2005.

FERREIRA JR., A.; BITTAR, M. Educação e Ideologia Tecnocrática na Ditadura Militar. Cadernos CEDES, Campinas, v. 28, n.76, p. 333-355, 2008.

FREITAS, K. S. de; PILLAS, S. B. Gestão democrática da educação. In: Caderno de Texto, v. 3, Programa de apoio aos dirigentes municipais de educação - PRADIME, MEC/SEB, Brasília, MEC, 2006.

FOPROP. Relato Reunião CTC Capes 24-28/08/09. Disponível em: $<$ http://www.foprop.org.br/wp-content/uploads/2010/05/Relato-da-111\%C2 \%AA-Reuni\%C3\%A3o-CTC-CAPES.pdf>. Acesso em: 12 fev. 2014.

GATTI, B. et al. O Modelo de Avaliação da CAPES. Revista Brasileira de Educação, Rio de Janeiro, n. 22, jan./fev./mar./abr. 2003.

GOUVEIA, A. A pesquisa educacional no Brasil. Revista Brasileira de Estudos Pedagógicos, Brasília, n. 55, 1971.

GOUVÊA, F.; MENDONÇA, A. da. Pós-Graduação no Brasil: um percurso com os boletins da Capes. Perspectiva, Florianópolis, v. 24, p. 111-132, 2006. 
HORTA, J. S. B.; MORAES, M. C. M. de. O Sistema Capes de Avaliação da Pós-Graduação: da Área de Educação à Grande Área de Ciências Humanas. Revista Brasileira de Educação, Rio de Janeiro, n. 30, p. 95-116, 2005.

Avaliação da pós-graduação: com a palavra os coordenadores de programas. Perspectiva, Florianópolis, v. 24, n. 1, p. 19-47, jan./jun. 2006.

HORTALE, V. A. Modelo de Avaliação Capes: desejável e necessário, porém, incompleto. Cadernos de Saúde Pública, Rio de Janeiro, v. 19, n. 6, p. 18371840, 2003.

; MORA, J. G. Tendências das Reformas da Educação Superior na Europa no Contexto do Processo de Bolonha. Educação \& Sociedade, Campinas, v. 25 , n. 88, p. 937-960, especial - out. 2004.

JOSLIN, M. de F. A. A política de inclusão em questão: uma análise em escolas da rede municipal de ensino de Ponta Grossa - PR. 2012. 144 f. Dissertação (Mestrado em Educação) - Setor de Ciências Humanas, Letras e Artes, Universidade Estadual de Ponta Grossa, Ponta Grossa.

KINZO, M. D. G. A democratização brasileira: um balanço do processo político desde a transição. São Paulo em Perspectiva, São Paulo, v. 15, n. 4, p. 3-12, 2001.

KUENZER, A. Z.; MORAES, M. C. M. Temas e tramas na pós-graduação em educação. Educação \& Sociedade, Campinas, v. 26, n. 93, p. 1341-1362, 2005.

LIRA, A. T. N. A legislação da educação no Brasil durante a ditadura militar (1964 - 1985): um espaço de disputas. 2010. 367 f. Tese (Doutorado em História Social) - Departamento de História, Universidade Federal Fluminense, Niterói.

MACEDO, L.; MENANDRO, P. R. M. Considerações sobre os indicadores de produção no processo de Avaliação dos Programas de Pós-Graduação em Psicologia. Infocapes, Brasília, v. 6, n. 3, p. 34-38, 1998.

MACEDO, E.; SOUSA, C. P. de. A pesquisa em educação no Brasil. Revista Brasileira de Educação, Rio de Janeiro, v. 15 n. 43, jan./abr. 2010.

MAINARDES, J. Abordagem do ciclo de políticas: uma contribuição para análise de políticas educacionais. Educação \& Sociedade, Campinas, v. 27, n. 94, p.4769, 2006.

2007.

. Reinterpretando os ciclos de aprendizagem. São Paulo: Cortez,

; MARCONDES, M. I. Entrevista com Stephen J. Ball: um diálogo sobre justiça social, pesquisa e política educacional. Educação e Sociedade, Campinas, v. 30, p. 303-318, 2009. 
MANZINI, E. J. Avaliação de periódicos científicos: Revista Brasileira de Educação Especial. Revista Brasileira de Educação Especial, Marília, v. 19, n. 1, p. 121-130, jan./mar. 2013.

MARCHLEWSKI, C.; SILVA, P. M. da; SORIANO, J. B. A influência do Sistema de Avaliação Qualis na produção de conhecimento científico: algumas reflexões sobre a Educação Física. Motriz, Rio Claro, v.17 n.1, p.104-116, jan./mar. 2011.

MARQUES, F. A escala da discórdia: novos critérios do Sistema Qualis, da Capes, recebem críticas da comunidade científica. Pesquisa FAPESP, São Paulo, n.160, jun. 2009.

MELO, M. A. O Sucesso Inesperado das Reformas de Segunda Geração: Federalismo, Reformas Constitucionais e Política Social. DADOS - Revista de Ciências Sociais, Rio de Janeiro, v. 48, n. 4, p. 845-889, 2005.

MENDONÇA, E. F. A regra e o jogo: democracia e patrimonialismo na educação brasileira. Campinas: FE/UNICAMP, 2000.

MENDONCA, A. W. P. C.; OLIVEIRA, M. T. C.; PIMENTA, J. S. Pensamento e ação de Anísio Teixeira: a Capes dos anos 50/60. Anais do V Congreso Iberoamericano de Historia de la Educación Latinoamericana; 2001; V Congreso Latinoamericano de Historia de la Educación Latinoamericana. San Jose, Costa Rica: Universidad de Costa Rica, português, CD-ROM.

MINAYO, M. C. de S.; SANCHES, O. Quantitativo-qualitativo: oposição ou complementaridade? Cadernos de Saúde Pública, Rio de Janeiro, v. 9, n.3, p. 237-248, 1993.

MOREIRA, A. F. B. A cultura da performatividade e a avaliação da PósGraduação em Educação no Brasil. Educação em Revista, Belo Horizonte, v.25, n. 3, p. 23-42, dez. 2009.

MOROSINI, M.C. A pós-graduação no Brasil: formação e desafios. Revista Argentina de Educación Superior, Buenos Aires, n. 1, nov. 2009.

OLIVEIRA, M. R.; ALMEIDA, J. Programas de pós-graduação interdisciplinares: contexto, contradições e limites do processo de avaliação Capes. Revista Brasileira de Pós-Graduação, Brasília, v. 8, n. 15, p. 37 - 57, mar. 2011.

OLIVEIRA, A.; LOPES, A. A abordagem do ciclo de políticas: uma leitura pela teoria do discurso. Cadernos de Educação, Pelotas, v. 38, p. 19-41, 2011.

ROCHA e SILVA, M. Carta aberta ao presidente da Capes: o novo Qualis, que não tem nada a ver com ciência do Brasil. Clinics, São Paulo, v. 64, n. 8, 2009.

O novo Qualis e o futuro dos periódicos científicos brasileiros. Scientia Medica, Porto Alegre, v. 19, n. 3, p. 96-97, jul./set. 2009. 
PINTO, A. C.; CUNHA, A. Avaliação da pós-graduação da Área de Química na Capes. Química Nova, São Paulo, v. 31, n. 8, p. 2221-2226, 2008.

PONTIFÍCIA UNIVERSIDADE CATÓLICA DO RIO GRANDE DO SUL. Regulamento do Programa de Pós-Graduação em Educação. Porto Alegre, RS, 2010.

ROTHEN, J. C. Os bastidores da Reforma Universitária de 1968. Educação \& Sociedade, Campinas, v. 29, n. 103, p. 453-475, maio/ago. 2008.

SANTANA, A.; MARTINS, H. F. Gestão estratégica de políticas públicas: a Capes e a política de formação de recursos humanos para o desenvolvimento do país. Anais do V Congresso de Administração Pública. Brasília: Centro de Convenções Ulysses Guimarães, 2012.

SANTOS, C. M. dos. Tradições e contradições da pós-graduação no Brasil. Educação \& Sociedade, Campinas, v.. 24, n. 83, p. 627-641, ago. 2003.

SANTOS, A. L. F.; AZEVEDO, J. M. L. A pós-graduação no Brasil, a pesquisa em educação e os estudos sobre a política educacional: os contornos da constituição de um campo acadêmico. Revista Brasileira de Educação, Rio de Janeiro, v.14, n.42, p. 534-550, 2009.

SAVIANI, D. A pós-graduação em educação no Brasil: trajetória, situação atual e perspectivas. Revista Diálogo Educacional, Curitiba, v. 1, n. 1, p. 1-19, jan./jun. 2000.

Escola e democracia: teorias da educação, curvatura da vara, onze teses sobre a educação política. 36. ed. Campinas, SP: Autores Associados, 2003.

SEVERINO, A. J. A Política de pós-graduação no Brasil: avaliando a avaliação. Anais da 26 . Reunião Anual da Anped. Poços de Caldas: Hotel Carlton; Palace Hotel; São Francisco; Hotel Minas; Nacionl Inn; Palace Cassino; Complexo Cultural Urca; Hotel Joia, 2003. Disponível em: <http://26reuniao.anped.org.br/>. Acesso em: 07 jan. 2014.

SILVA, E. L. da; MENEZES, E. M. Metodologia da pesquisa e elaboração de dissertação. 3. ed. rev. atual. Florianópolis: Laboratório de Ensino a Distância da UFSC, 2001. 121p.

SILVA, A. O. da. Maurício Tragtenberg e a pedagogia libertária1. Revista Didática Sistêmica, Rio Grande, v. 1, out./dez. 2005.

SILVA JÚNIOR, J. R.; FERREIRA, L. R.; KATO, F. B. G. Trabalho do professor pesquisador diante da expansão da pós-graduação no Brasil pós-LDB. Revista Brasileira de Educação, Rio de Janeiro, v. 18, n. 53, p. 435-499, abr./jun. 2013. 
SOUSA, C.; MACEDO, E. Avaliação da pesquisa em educação e indicadores de produção bibliográfica: um relato sobre o Qualis Periódicos. Educational Research Evaluation and Bibliographical Products: A Report About the Journals Qualis. Revista de Educação Pública, Cuiabá v. 18, n. 37, p. 255-272, maio/ago. 2009.

SOUZA, C.; CARVALHO, I. M. M de. Reforma do Estado, descentralização e Desigualdades. Lua Nova, São Paulo, 1999, n. 48, p. 187-212, 1999.

SOUZA, J. P.; PEREIRA, L. B. Pós-Graduação no Brasil: análise do processo de concentração. Acta Scientiarum, Maringá, v. 24, n.1, p. 159-166, 2002.

SPAGNOLO, F.; SOUZA, V. C. O Que mudar na avaliação da CAPES? Revista Brasileira de Pós-graduação, Brasília, v. 1, n. 2, p. 8-34, nov. 2004.

TEIXEIRA, J. C. et al. Dinâmica de distribuição de fontes de capitais científicos entre docentes/pesquisadores de um programa de pós-graduação stricto-sensu de uma universidade pública. Avaliação, Campinas; Sorocaba, v. 17, n. 1, p. 179206, mar. 2012.

THIRY-CHERQUES, H. R. Pierre Bourdieu: a teoria na prática. Revista de Administração Pública, Rio de Janeiro, v. 40, n. 1, p. 27-55, jan./fev. 2006.

TREIN, E.; RODRIGUES, J. O mal estar na academia: produtivismo científico, o fetichismo do conhecimento-mercadoria. Revista Brasileira de Educação, Rio de Janeiro, v. 16, n.. 48, p. 769-792, set./dez., 2011.

UNIVERSIDADE DO ESTADO DO RIO DE JANEIRO. Deliberação no 042/2010 - Aprova a reformulação do Programa de Pós-graduação em Educação, cursos de Mestrado Acadêmico e Doutorado. Rio de Janeiro, RJ, 2010.

UNIVERSIDADE FEDERAL DE MINAS GERAIS. Programa de PósGraduação: Conhecimento e Inclusão Social em Educação. Resoluçãa $\mathbf{n}^{\mathbf{o}}$ 01/2007. Belo Horizonte, MG, 2007.

Faculdade de Educação. Programa de Pós-Graduação em Educação. Resolução no 03/2011. Belo Horizonte, MG, 2011.

Regulamento do Programa de Pós-Graduação em Educação: Conhecimento e inclusão social. Belo Horizonte, MG, 2013.

UNIVERSIDADE DO VALE DO RIO DOS SINOS. Regimento Interno do Programa de Pós-Graduação em Educação da Unisinos. São Leopoldo, RS, 2010.

VAROTTO, M. A educação como "salvadora da pátria": uma análise das políticas educacionais proclamadas pelo Estado Brasileiro, principalmente, na segunda fase do regime militar, a fim de restaurar e renovar sua legitimidade social. Cadernos da Pedagogia, São Carlos, v. 1, n, 1, p. 42-50, jan./jul. 2007. 
VERHINE, R. E. A Gestão do Financiamento da Educação Básica: um estudo longitudinal e comparativo no contexto do Estado da Bahia. Revista Em Aberto, Brasília, n. 75, p. 98-112, 2002.

. Pós-graduação no Brasil e nos Estados Unidos: uma análise comparativa. Educação, Porto Alegre, v. 31, n. 2, p. 166-172, maio/ago. 2008.

; DANTAS, L. M. S. Reflexões sobre o sistema de avaliação da Capes a partir do V Plano Nacional de Pós-graduação. Revista de Educação Pública, Cuiabá, v. 18, n. 37, p. 295-310, maio/ago. 2009.

; FREITAS, A. A. S. M. A avaliação da educação superior: modalidades e tendências no cenário internacional. Revista Ensino Superior, Campinas, p. 16-39, 2012.

VILAÇA, M. M.; PALMA, A. Espaço aberto: diálogo sobre cientometria, malestar na academia e a polêmica do produtivismo. Revista Brasileira de Educação, Rio de Janeiro, v. 18 n. 53, p. 467-500, abr./jun. 2013.

XAVIER, L. N. A pesquisa do CBPE em Revista. In: BRANDÃO, Z; MENDONÇA, A. W. (Orgs.). Por que não lemos Anísio Teixeira? Uma tradição esquecida. Rio de Janeiro: Ravil, p. 85-139, 1997.

O Brasil como laboratório: educação e Ciências Sociais no projeto do Centro Brasileiro de Ciências Sociais (CBPE-INEP_MEC / 1950-60). 1999, Tese (Doutorado em Educação) - Pontifícia Universidade Católica do Rio de Janeiro, Rio de Janeiro. 
10.

Anexos

\section{Anexo 1 - Roteiro de entrevista com coordenadores de curso}

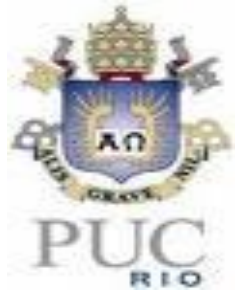

Pontifícia Universidade Católica do Rio de Janeiro

Programa de Pós-Graduação em Educação

Orientadora: Prof ${ }^{\mathrm{a}}$. Dr ${ }^{\mathrm{a}}$. Alicia Bonamino

Doutoranda: Indira Alves França

\section{ENTREVISTA COM COORDENADORES DE CURSO}

Programa: ( ) Unisinos ( ) PUCRS ( ) UFMG ( ) UERJ

Nome do Entrevistado:

Período da coordenação:

Data da entrevista:

\section{ROTEIRO}

$\checkmark$ Solicitar assinatura do termo de consentimento

$\checkmark$ Ligar os equipamentos de gravação

$\checkmark$ Explicar resumidamente a pesquisa (gestão de programas de excelência que avançaram duas notas de 2001-2010)

$\checkmark$ Comentar intuito da entrevista com coordenadores - trabalho coordenação é o foco da pesquisa - observar dificuldades, estratégias e diferenças entre os programas da pesquisa.

$\checkmark$ Tópicos da entrevista: 1) experiência do programa e avaliação da capes 2) trabalho de coordenação 3) estrutura de apoio à coordenação 4) Documentos sobre a política de PG 5) Docentes e discentes

\section{Experiência do programa e Avaliaç̃o da Capes}

O programa da saiu de uma nota em 2001 e chegou a nota em Hoje é um programa de excelência na área da Educação.

1) Fale um pouco sobre a sua percepção em relação à evolução do programa em termos de nota da Capes (a que atribui o avanço nos resultados? Foi uma mudança induzida/projetada? Como foi o processo? Que pontos destacaria?)

2) Considera que o trabalho de coordenação (gestão) ajudou nesse processo? De quê forma?

3) Houve alguma ação induzida específica para melhorar os quesitos avaliados pela Capes, como: 
a) Corpo docente

b) Corpo discente

4) Em sua atuação como coordenador, leva(va) em consideração o peso dos quesitos da avaliação? Considera que a avaliação influencia seu cotidiano de trabalho?

5) Quais os principais desafios/dificuldades para chegar a esse desempenho e mantê-lo?

6) O que mudou para o programa, em termos práticos, ao obter a classificação de "programa de excelência"?

7) Qual a sua opinião sobre o processo de avaliação da Capes? O que teria a destacar como positivo? E negativo?

Existe um reconhecimento na área acadêmica de que o sistema de avaliação da Capes possibilitou grandes avanços à pós-graduação brasileira. No entanto, a própria Capes e alguns autores apontam distorções e necessidades de ajustes no atual sistema de avaliação da pós-graduação. Qual sua opinião sobre elas? (abaixo)

a) O modelo é produtivista - quantidade é mais valorizada que a qualidade;

b) O modelo tem caráter homogeneizador;

c) Há predominância de parâmetros das ciências exatas e naturais para avaliação das ciências humanas e sociais;

d) A periodicidade entre as avaliações é curta;

e) Há pouca valorização da dimensão social;

f) A inserção internacional é um quesito ainda não bem definido;

8) Considera que os programas têm espaço de participação na elaboração e discussão das diretrizes da política de pós-graduação no país?

\section{Trabalho de coordenacão}

A gestão de programas de pós-graduação tem se tornado uma atividade cada vez mais complexa, pois envolve cuidar de diferentes aspectos, como: produção intelectual do Programa, internacionalização da pesquisa, formação dos alunos, questões administrativas e financeiras, avaliação, integração do programa em redes de pesquisa, etc. Diante disso:

9) Que questões da pós-graduação considera que são (foram) prioritárias desenvolver/dar mais atenção em seu trabalho de coordenador de programa?

10) Quais os maiores desafios que considera no trabalho de coordenação do programa? Por quê?

11) Teve algum tipo de formação ou preparação para a atuação como gestor de um PPG?

12) O que considera que poderia ser feito pelas instituições (universidades, capes, MEC) para contribuir com o trabalho dos coordenadores de programa? 
13) Qual a parte mais interessante de coordenar um programa de pósgraduação?

14) Como se tornou coordenador do programa? (provimento ao cargo)

15) Recebeleu gratificação pela função?

16) Quando/como deixou o cargo? (se for o caso)

\section{$\underline{\text { Estrutura de apoio à coordenacão }}$}

17) Existe colegiado no programa?

18) O colegiado contribui para o trabalho de gestão do programa?

19) No trabalho de coordenação do programa, recebe (recebeu) algum tipo de apoio:

- da Capes? Que tipo?

- de coordenador(es) adjunto(s)? Que tipo?

- da secretaria acadêmica? Que tipo?

- outros (especificar)

20) Além do regulamento do programa, há outros documentos que colaboram com o estabelecimento de normas no curso?

21) Em relação à infraestrutura do programa: considera adequada? Precisa ampliar/melhorar algo?

\section{Documentos relativos à política de Pós-graduacão}

22) Qual(is) documento(s) da política nacional de pós-graduação (PNPGs, portarias, relatórios de avaliação, regulamentos...) que considera importante para a orientação da sua prática profissional como coordenador? Por quê?

23) Você conhece o atual PNPG?

24) Considera que as diretrizes do plano interferem no programa que coordena (ou)?

25) E o documento de área?

26) Considera que as diretrizes do documento interferem no programa que coordena $(\mathrm{ou})$ ?

\section{Docentes e Alunos}

27) Quais as maiores dificuldades que observa que os docentes enfrentam na realização de seu trabalho na pós-graduação?

28) Quais as maiores dificuldades que os discentes enfrentam na realização de seus estudos? 
Anexo 2 - Exemplo de entrevista com coordenador de curso

\author{
TRANSCRIÇÃO DE ÁUDIO - ENTREVISTA COORDENADOR A \\ PUCRS
}

\begin{abstract}
Entrevistadora: Professora, a senhora vai ser a primeira coordenadora que eu vou entrevistar porque estou começando pelo Sul, vou entrevistar o pessoal de Minas e, por último, o pessoal do Rio porque optei primeiro pelos lugares mais distantes. Então se tiver alguma questão mal compreendida, que não quiser responder, fica a vontade e vamos lá. Você entrou em dezembro? Então é bem recente também, bem recente? Mas a senhora já era professora do Programa?
\end{abstract}

Coordenador A - PUCRS: Sou professora aqui desde 2009.

Entrevistadora: Ah, tá.

Coordenador A - PUCRS: E também não é muito tempo.

Entrevistadora: Eh, não é. Mas acompanhou um pedaço do processo. Não sei se você vai ter condições de me responder essa primeira questão, mas do seu ponto de vista, de 2009 para cá. O Programa da PUC saiu da nota 4, em 2001, e chegou a nota 6 em 2010 e hoje é um Programa de excelência. Eu queria que você falasse um pouco sobre a sua percepção em relação à evolução do Programa em termos de nota da Capes. A que você atribui esses avanços? Foi uma mudança projetada pela equipe? Como foi esse processo?

Coordenador A - PUCRS: Então, eu posso te ajudar muito pouco nessa resposta porque quando eu entrei em 2009, o Programa já era 6. Ele tinha recém sido avaliado com nota 6 . Então, na verdade, eu não posso te contar muito sobre como foi esse ajuste, quem acho, aí quem vai poder te dizer bem isso é o (coordenador anterior). Porque a minha percepção é que foi uma conquista da gestão (desse coordenador), que é um gestor muito empreendedor, muito conectado, muito ágil. E a minha percepção é que essa mudança da nota tem a ver com o período em que (ele) assumiu o Programa. O Programa esteve durante muitos anos sob a coordenação do (coordenador do período 2001-2008) como, não sei, 14 anos, foi bastante tempo, eu também não tenho esse dado, mas, assim, certamente mais de 10 anos. E a entrada do (coordenador anterior) antecedeu e marcou, assim, um período de renovação e de uma politica mais focada em atingir as metas que a Capes estabeleceu.

Entrevistadora: É, talvez, aqui você já respondeu a segunda questão, se considera o trabalho da coordenação importante nesse processo, então fundamental?

Coordenador A - PUCRS: Eu acho que sim. A minha percepção, agora, como eu te digo, é uma percepção de quem já chegou em 2009, quem não esteve vivendo a gestão (2001-2008), mas é o que eu posso perceber desse tempo que eu cheguei. 
Entrevistadora: E eu acho, talvez, que essa aqui também fique um pouco difícil, mas vamos ver. Você sabe se houve alguma ação induzida em relação ao corpo docente, por exemplo, em termos de produção? Houve algum incentivo ou foi só, assim, algum incentivo que eu digo mais concreto, como: "precisamos produzir tantos artigos"...

Coordenador A - PUCRS: Olha, o que o (coordenador anterior) fez e que de alguma maneira a gente segue fazendo é uma, digamos, um monitoramento da produção do professor e em alguns momentos de reuniões gerais ou mesmo reuniões com os professores, uma devolução do quadro de produção no sentido de fazer um balanço. Eu acho que tem um processo quase formativo, claro não é, a gente tem o cuidado de não expor os professores, de nunca fazer essas devoluções com os nomes dos professores...

Entrevistadora: Comparando.

Coordenador A - PUCRS: Comparando, a gente tem, claro, esse cuidado. Mas o que a gente faz é mostrar perfis gerais da equipe. Então, por exemplo, muitas produções em anais de congresso, isso não é interessante, não é pontuado para a Capes. Ou produções em revistas locais, sei lá, B4, por exemplo, a gente mais ou menos, nós pontuamos quando publicamos dentro da faixa Qualis A e B até B2, me parece. Então o que a gente faz, em reuniões com os professores, periodicamente em alguns momentos, a gente faz um balanço geral para, digamos, criar uma cultura também, difundir uma informação e criar uma cultura de publicações que levem em conta o Qualis das revistas porque isso é uma mudança mais ou menos recente em termos da politica da Capes. Não é? Então os professores que estão aqui há muitos anos, 20 anos, 30 anos, nós temos professores que estão aqui há muito tempo e isso não era assim antes. Então se trata um pouco de criar uma atenção para isso.

Entrevistadora: Um parêntese, em relação a essa questão do quadro docente, um panorama, assim, do quadro. Você acha que a maior parte dos professores já está há muito tempo, ou está meio a meio?

Coordenador A - PUCRS: Não, nós temos, uma boa parte dos professores são bem antigos. Nosso Programa é um Programa com professores mais idosos e que estão aqui há muito tempo, tanto que tem sido uma politica nossa nas contratações recentes buscar diminuir a média de idade do Programa. A gente tem procurado professores mais jovens e que ao mesmo tempo sejam sêniores em termos de produtividade científica, que é um perfil bastante difícil.

Entrevistadora: Bem difícil (risos).

Coordenador A - PUCRS: Mais difícil, o mais difícil.

Entrevistadora: Alguém que tenha começado jovem a produzir que esteja na...

Coordenador A - PUCRS: Que esteja na faixa, por exemplo, dos 40 anos, 35, 40 anos ou até um pouco mais, mas que já seja, que já tenha uma experiência, 
que já tenha produção, que já tenha experiência docente, professores de meio de carreira, digamos assim, com alta produtividade.

Entrevistadora: E em relação ao corpo discente, a política é parecida, é similar?

Coordenador A - PUCRS: Nós temos como requisito parcial para obtenção do título de doutorado a exigência de quatro publicações, uma por ano.

Entrevistadora: Ah, para o doutorado quatro publicações.

Coordenador A - PUCRS: É, quatro publicações, uma por ano e elas variam entre publicação em periódico, publicação em trabalhos completos publicados em congressos, resumos, resenhas, a gente admite um conjunto de publicações.

Entrevistadora: Essas regras, elas...

Coordenador A - PUCRS: Organização de livro, isso tem, nós temos um, uma portaria.

Entrevistadora: Uma portaria? Eu poderia ter acesso?

Coordenador A - PUCRS: Sim, eu acho que ela está até no site do Programa, essa portaria.

Entrevistadora: Eu dei uma olhada. Eu achei o regulamento, mas também são quatro programas, eu posso ter me confundido.

Coordenador A - PUCRS: É, dá uma olhadinha. Eu acho que essa portaria está no site do Programa.

Entrevistadora: Se eu não encontrar, depois eu posso mandar um e-mail?

Coordenador A - PUCRS: Está bem, depois você me manda um e-mail e eu te passo. Tem uma portaria estabelecendo tudo isso.

Entrevistadora: A produtividade?

Coordenador A - PUCRS: A produtividade do aluno.

Entrevistadora: É do doutorando?

Coordenador A - PUCRS: É do doutorando, do mestrando não. O mestrando a gente incentiva a produtividade, mas ela não é condição para o titulo.

Entrevistadora: Tá, é...

Coordenador A - PUCRS: Uma outra coisa que a gente tem feito nesse sentido é com o acompanhamento dos bolsistas. Já desde o ano passado, eu estava até na presidência da comissão de bolsas antes de assumir a coordenação e acompanhei 
bem isso. Faz dois anos que a gente instituiu a comissão de bolsas, que é até uma exigência da Capes ter a comissão de bolsas e que nós, além da distribuição, que é meritocrática, a gente faz um acompanhamento do aluno bolsista. Então, uma vez por ano eles entregam um relatório e a gente avalia, a gente tem um quadro de avaliação aonde a produtividade entra para mestrandos e doutorandos. Então, assim, o que publicou, o que, aí que atividades dentro do Programa participou, de congressos, aí a gente não é só produção, mas a produção é um item.

Entrevistadora: E esse perfil é avaliado sob o risco do aluno perder a bolsa? Alguma coisa assim? Ou...

Coordenador A - PUCRS: No limite sim. A ideia não é tirar a bolsa de ninguém, mas também é detectar situações onde o aluno já não tem nenhuma produtividade ou nenhum tempo para participar das atividades do Programa porque isso acontece muito. $\mathrm{O}$ aluno ganha bolsa quando entra e depois ele assume um monte de atividades outras, ou mesmo um trabalho, e ele acaba se tornando um aluno, por exemplo, que vem só para a sala de aula. Então, isso é que a gente quer evitar que aconteça com aluno bolsista. Então, fazendo esse monitoramento anual a gente percebe os casos aonde isso tem/pode está começando a acontecer ou já está acontecendo e a gente chama para conversar, para saber a situação e tal.

Entrevistadora: Muito bom, assim, porque eu acho que um dos objetivos mesmo da minha pesquisa é descobrir esse tipo de prática e só nessa primeira já estou descobrindo aí várias coisas interessantes. Muito legal.

Coordenador A - PUCRS: A gente tem feito isso há dois anos, então, isso a gente... A política não é assim, a gente não faz nenhum terrorismo, não é tirar bolsa, a gente nunca tirou bolsa de ninguém (mesmo nessa situação), mas o fato da gente ter um acompanhamento, os próprios alunos também se sentem, digamos, numa posição de...

Entrevistadora: De responsabilidade.

Coordenador A - PUCRS: De responsabilidade, de explicar, entendeu, "que esse ano eu fiquei doente", "que aconteceu tal coisa", então "esse ano eu não pude fazer, não sei o quê", sabe. Claro que leva em conta os motivos e tal, mas já aconteceu, por exemplo, um caso aonde a bolsista, a pessoa, que aqui a gente tem duas modalidades de bolsa: bolsa parcial, que é só a isenção das taxas e o aluno pode trabalhar; e a bolsa integral, que não pode trabalhar. Aconteceu já de uma menina que tinha bolsa integral assumir 40 horas de um trabalho super executivo, dentro mesmo da Rede Marisa, que a gente sabe que é super pesado, e por ela mesma ela não teria aberto mão da bolsa, só porque a gente chamou e conversou. E aí ela, e aí o que aconteceu, a gente mudou o tipo de bolsa. A gente falou, bom, dentro do seu perfil agora você é uma bolsista só com isenção de taxas porque já não pode ter, vai contra as regras da Capes um trabalho tão intenso. Então daí a gente mudou o tipo de bolsa. Então é isso, a ideia é essa, até porque os colegas, tem gente esperando bolsa, podendo... 
Entrevistadora: Se dedicar mais...

Professora Coordenador A - PUCRS pede licença para atender telefonema.

Entrevistadora: A outra pergunta é em relação ao peso dos quesitos da Área de Educação, eles vêm mudando ao longo dessa ultima década também, o peso maior agora está na produção intelectual e eu queria saber se o peso, se isso fica na cabeça do coordenador na hora de atuar no programa de pós-graduação, tipo: "eu tenho que priorizar isso porque isso é o mais importante". De acordo com os pesos, se isso mexe um pouco com a sua rotina de trabalho de coordenadora ou não chega a tanto?

Coordenador A - PUCRS: O item produção intelectual?

Entrevistadora: É, os que são mais pesados, no caso a produção intelectual...

Coordenador A - PUCRS: Pois é, bom, claro que sim porque a gente sabe que a avaliação do programa depende da manutenção da produção intelectual. Então, por exemplo, isso faz com que a gente se preocupe com um professor que não está conseguindo manter um índice de produção intelectual, a gente tem aqui na PUC um processo periódico de recadastramento dos professores no Programa. Esse recadastramento depende da produção intelectual. Então claro que isso gera também políticas internas de...

Entrevistadora: É a política de credenciamento e descredenciamento?

Coordenador A - PUCRS: Exatamente.

Entrevistadora: Essa política também vocês tem por escrito alguma coisa ou não? Tem alguma coisa, assim, em termos de regra? Por exemplo, "o professor precisa..." porque alguns programas têm, é comum, "mínimo ser tanto por ano, triênio, pegar tantas disciplinas" ou isso está mais no...

Coordenador A - PUCRS: Digamos assim, isso... Nós estabelecemos em comissão coordenadora, por exemplo, critérios de cadastramento de professor no Programa e recadastramento que tem haver com a produção intelectual, aderência, são critérios como aderência, produção intelectual...

Entrevistadora: A minha pergunta é: Esses critérios eles estão, assim, objetivados? Entendeu? Em termos quantitativos...

Coordenador A - PUCRS: É estou tentando, por exemplo, estou tentando me lembrar se tem um documento nesse sentido ou se isso é ata de comissão coordenadora, entendeu, que também é um documento, mas não é, assim, não é uma portaria. Eu acho que não é uma portaria, eu não estou segura para te responder, eu teria que dar uma olhada. Porque a nossa pró-reitoria de pesquisa tem critérios também, o que a gente faz, tem critérios mais gerais, o que a gente faz é ajustar os critérios para a realidade de cada programa e aí a gente faz isso em nível de comissão coordenadora do Programa, mas seguindo uma política da Universidade. Então, precisaria pesquisar um pouquinho os documentos para 
ver, mas a gente tem anualmente um balanço de levantamentos de professores, o prazo para isso, o prazo que também nos falta aí é o triênio, que são relatórios enviados para a Capes, ao final do triênio, então, a gente faz um balanço trienal disso e você perguntou uma outra coisa do...

Entrevistadora: Acho que se isso influencia no seu cotidiano do trabalho...

Coordenador A - PUCRS: É, enfim, influencia, por exemplo, é isso, nas rotinas de credenciamento e quando a gente faz o relatório Capes a gente tem que indicar também, na autoavaliação o que a gente considera que são pontos frágeis e o que a gente considera que a gente tem que fazer para melhorar. Então essa questão da produtividade, ela está aí também, ela vai entrar aí. Se você tem, por exemplo, a gente pode justificar, por exemplo, um período de menos produção de um professor por uma questão de saúde, até a gente teve uma situação assim bem seria. É claro que isso a gente leva em conta, mas então depois a gente busca orientar esse professor para que no momento seguinte ele se preocupe, retome e tal. Então, assim, isso é especifico e faz parte da gestão e a gente está olhando para isso. Então é claro que isso influencia no cotidiano da gestão.

Entrevistadora: Eu não sei se para chegar a esse desempenho, que a pergunta era assim: Quais foram os principais desafios para se chegar a esse desempenho? Acho que não acompanhou esse processo, mas eu poderia te perguntar assim: Para manter esse desempenho, é muito difícil? Você considera que é difícil, que é um trabalho...

Coordenador A - PUCRS: Eu acho que sim, eu acho que é difícil porque as metas estão sempre indo para cima, a Capes, ela vai ajustando tudo para cima de certa forma. Tem uma, a gente vive um, digamos, um afunilamento dos espaços de publicação, você tem um, acho que somos uns 112 programas no Brasil, a Área da Educação é uma Área numerosa, um Programa de Pós-Graduação, você imagina todos esses professores sofrendo essa pressão, a mesma pressão por publicação em periódicos qualificados, o que chega nessas revistas? Atualmente está demorando, tipo, 1 ano para você conseguir publicar. Nós temos uma revista Qualis A2, a gente sabe o fluxo que essa revista tem, é uma coisa incrível, chega muito trabalho, então eu acho que a gente vive um afunilamento, uma exigência de publicação e não temos tantos canais assim de publicação nesses periódicos qualificados, então tem um estrangulamento aí. Então claro que isso é difícil de manter. Além disso eu acho que o gestor de um programa de pós-graduação, no momento que a gente está vivendo, ele também tem que ter um pouco de bom senso porque não dá para a gente também...

Entrevistadora: Só pensar nisso.

Coordenador A - PUCRS: Só pensar nisso! Quer dizer, você também não pode deixar a política da Capes transformar, se transformar numa tirania, numa meta, num fator de stress que pode reverter negativamente para o clima organizacional, para o clima, entendeu, de funcionamento do Programa, ou seja, se as pessoas, se essa é a ideia de que todo mundo produza, você tem que ter um pouco de saúde, de um clima saudável, de um clima propício para, ninguém 
produz pelo terror, pela pressão, pela ameaça, entendeu, "vai descredenciar", "vai não sei o que", "o Programa vai perde nota"...

Entrevistadora: E a gente sabe que a área acadêmica está sofrendo muito com isso também. Acho que tem até uma pergunta mais à frente em relação a isso, mas só queria te fazer uma pergunta antes que ainda está dentro desse contexto aqui, da experiência do programa e da avaliação da Capes, que é assim: ao ser transformado em programa de excelência o que mudou para o Programa?

Coordenador A - PUCRS: Olha, mudou. Acho que muda o status do Programa dentro da Universidade, a gente pode, então, contar com um maior reconhecimento dentro da Universidade, acho que essa é a primeira vantagem interna, assim, de saída. Nós melhoramos a nossa quantidade de bolsas, isso é um beneficio direto muito importante. Você imagina que a gente foi um Programa 6, que até agora no finalzinho do triênio nós tínhamos apenas 1 bolsa de doutorado integral CNPq, uma única.

Entrevistadora: E da Capes?

Coordenador A - PUCRS: Da Capes só tinha bolsa parcial. O que eu achava, por exemplo, um absurdo isso, como é que um Programa 6 só tem uma bolsa, nós temos 1 aluno apenas, doutorando, com bolsa integral do CNPq. Então agora não, agora nós temos 9 bolsas integrais e faz toda a diferença porque o aluno que vai fazer esse perfil realmente de se transformar em um intelectual, um pesquisador, ele é um bolsista integral, entendeu, que vai fazer sanduíche, que vai fazer Pibid. Então eu acho que tem benefícios, nós não estamos ainda no Proex porque o Proex só chega eu acho no final do segundo triênio, então nós ainda não temos...

Entrevistadora: É depois de dois triênios que o programa é considerado de excelência é que...

Coordenador A - PUCRS: O programa é considerado de excelência desde a primeira nota 6. Acontece que ele precisa ser considerado um programa consolidado para poder entrar dentro desse, dessa política de gestão dos programas de excelência, que se chama Proex, que é onde a gente recebe recursos financeiros diretamente no Programa.

Entrevistadora: Os recursos de vocês ainda são do Proap, vocês recebem do Proap, não?

Coordenador A - PUCRS: Não, os nossos recursos... Aqui eu não conheço essa sigla, não sei se é coisa de Universidade Pública.

Entrevistadora: É porque lá no nosso a gente recebe, apesar de não, o nosso não ser um programa de excelência.

Coordenador A - PUCRS: Aqui o recurso da gestão cotidiana do Programa, eu recebo da pró-reitoria de pesquisa. A pró-reitoria distribui um valor anual para o Programa. 
Entrevistadora: Que é da própria Universidade? Ou é recurso da Capes também?

Coordenador A - PUCRS: Não sei. Eu não sei como que a pró-reitoria, da onde ela capta esse recurso. Eu tenho esse ano 30 mil reais, não é muito, é muito pouco porque isso é para trazer professor visitante, para incentivar professor nosso para participar de congresso, para aluno participar de congresso, para promover mesa redonda, não sei o que, é bem pouquinho tá, tem muito programa que acaba com isso rapidinho antes do final do ano. Então a gente recebe um pequeno, até para as minhas viagens de coordenadora a Capes, tudo isso sai desses 30 mil reais, bem pouquinho. $\mathrm{O}$ que mudou muito e mudou só este ano foi o produto, o novo produto da Capes, que repassou as bolsas diretamente para o Programa e por isso aumentou o nosso numero de bolsas. Antes as bolsas vinham para a pró-reitoria de pesquisa e a pró-reitoria de pesquisa distribuía para os programas. Agora a própria Capes fez essa distribuição, então teve programa que perdeu, perdeu bolsa e outros que ganharam, nós, por exemplo, ganhamos, ganhamos muitas bolsas, então melhorou.

Entrevistadora: Então, a sua opinião como professora também como coordenadora do processo de avaliação da Capes. O que teria, assim, a destacar como positivo e como negativo?

Coordenador A - PUCRS: Olha, eu acho que o processo de avaliação ele é mais positivo do que negativo, a minha posição, eu sei que isso é bem controverso, você vai ouvir diferentes posicionamentos. No corpo geral, eu acho que nós melhoramos muito com o processo de avaliação da Capes, eu acho que esse processo é responsável pela qualificação dos programas no Brasil e eu acho que ele trouxe mais benefícios que prejuízos. Então, de modo geral, eu estou de acordo e acho que foi muito importante esse programa ao longo dos anos para consolidação de uma pós-graduação no Brasil. Não é o caso da PUC, que a PUC é uma Universidade que realmente compra a ideia de ser uma Universidade de excelência, mas eu já trabalhei em outras Universidades privadas aonde a Capes nos protegia, entendeu? Graças aos critérios da Capes, nós podíamos manter certos compromissos com excelência porque se não fosse a Capes a Universidade de fato não bancaria uma série de coisas como: o aperfeiçoamento dos professores no pós-doutorado; limite de aulas; limite de horas/aula; manutenção de horas de pesquisa; esse tipo de, participação em congressos; sei lá. Se a gente não tivesse os argumentos da Capes a gente também internamente só daria aula, só ficaria em sala de aula, a pesquisa não aconteceria. Então eu acho que foi muito importante, que é muito importante. Agora, é claro, os pontos negativos eles, eu acho que está, digamos, primeiro em uma exigência de produtividade que é quantitativa e eu acho que a Capes está até repensando isso, eu acho que deveria ser a produtividade deveria ser avaliada pela qualidade das produções e não pela quantidade. A gente vive a síndrome da replicação dos artigos, ninguém, olha, pode ser os pesquisadores mais famosos, entendeu, ninguém mais tem condições de escrever trabalhos originais, completamente originais, e fazer o conhecimento avançar. Tá todo mundo replicando, integralmente/parcialmente. Por quê? Porque a produtividade vem marcando 
uma mensuração muito quantitativa. Eu acho que esses indicadores de produtividade deveriam ser menos quantitativos e mais qualitativos e a gente teria então uma produção cientifica de mais qualidade. Essa é a minha critica.

Entrevistadora: É, eu até separei porque na área acadêmica também tem esse reconhecimento, que o sistema da avaliação da Capes ele fez o sistema como um todo avançar, mas também a critica, principalmente, na própria Área da Educação, muitos críticos escrevendo sobre esse processo e criticando negativamente o processo de avaliação da Capes. Então, o primeiro é esse, que o modelo é produtivista, que a quantidade é mais valorizada que a qualidade, como você já colocou. Uma outra critica, e aí eu queria só que você se posicionasse, se você quiser em relação a isso, o que você considera, que o modelo tem um caráter homogeneizador, que equipara todos os programas, fiquem parecidos. Você concorda com isso?

Coordenador A - PUCRS: Eu concordo e acrescentaria que o problema da homogeneização é que é pautada por uma hegemonia do modelo das Ciências Exatas. Esse é o problema, eu não teria nenhum problema de pensar parâmetros, até globais, para todos os programas de Educação, são todos muito parecidos, não vejo nenhum problema de homogeneizar por aí. O problema é que essa homogeneização ela segue parâmetros de uma área que não é nossa, então, para a gente é muito importante livro, mas para as Áreas Exatas e Médicas o livro já não existe. Então aí a gente sai perdendo.

Entrevistadora: Exatamente a terceira crítica: a predominância de parâmetros das Ciências Exatas e Naturais em relação às Ciências Humanas e Sociais. Uma outra critica é que a periodicidade entre as avaliações é curta.

Coordenador A - PUCRS: Muito, inclusive há uma perspectiva da Capes de passar para 4 anos. O que eu acho correto. Eu concordo, é curta.

Entrevistadora: Há pouca valorização da dimensão social, dos aspectos sociais que o Programa pode realizar em relação à comunidade acadêmica, a comunidade do entorno mesmo do Programa, que o processo de avaliação valoriza pouco isso.

Coordenador A - PUCRS: É, mas isso já está mudando. Já foi até reconhecido pela Capes e está mudando porque mudou até o Currículo Lattes nesse sentido. O Currículo Lattes mudou a estrutura para valorizar justamente a, por exemplo, divulgação cientifica e ações de inserção social, isso já é, eu acho que é uma crítica, mas também a Capes já está caminhando nessa direção.

Entrevistadora: Você considera que os programas têm espaço de participação na elaboração e discussão das diretrizes da política de pós-graduação no país? Em que momento?

Coordenador A - PUCRS: Essa política é feita pelos pares. Por isso eu também acho que cada vez que a gente critica essa política, temos que criticar sabendo que somos nós que fazemos. 
Entrevistadora: Você se sente representada?

Coordenador A - PUCRS: Sim. Acho que nós temos representantes de Área, temos reuniões de Área, não concordo com essa critica, acho muito rasteira, muito assim simplista. Essa crítica de achar que quem está na, que a Capes é uma coisa e nós somos totalmente alijados, que vem de cima para baixo, não vem de cima para baixo, a gente tem varias instancias de participação.

Entrevistadora: Coleta Capes, quais as dificuldades... (risos).

Coordenador A - PUCRS: O Coleta Capes tem muito o que melhorar, tem muito, é um sistema que tem muito que melhorar, ele não é ajustado com o modelo do Lattes, ele não ... nossa! Ele tem que melhorar tecnicamente.

Entrevistadora: A quantidade de informações é um volume muito grande...

Coordenador A - PUCRS: É um volume muito grande, com informações muito detalhadas, que depois eu acho que elas desaparecem, sabe. A Capes nos comunicou já nesse... Que talvez esse seja o último ano que o Coleta Capes é feito com esse software, com esse sistema. Eles estão...

Entrevistadora: Criando a plataforma Sucupira.

Coordenador A - PUCRS: A plataforma Sucupira, exatamente, a gente vai ter outra plataforma.

Entrevistadora: Agora sobre o trabalho de coordenação em si, a gestão de programa de pós-graduação tem se tornado uma atividade cada vez mais complexa, tendo em vista que tem que cuidar de diferentes aspectos, a produção intelectual, a internacionalização da pesquisa, a formação dos alunos, as questões administrativo e financeira, avaliação, integração do programa com outras redes de pesquisa, enfim. Diante disso, que questões da pós-graduação considera que são prioritárias desenvolver mais, desenvolver e dar mais atenção no seu trabalho de coordenação do Programa? Quais as atividades da área de pós-graduação que seriam, assim, as principais, que você vê como mais importante?

Coordenador A - PUCRS: Eu acho que a gente não é possível estabelecer de inicio a priori, não é possível estabelecer prioridade, mas não é possível dizer a priori qual é a área mais relevante. Por quê? Porque o gestor ele tem que pensar a partir das dinâmicas do seu grupo de professores, então dependendo da dinâmica do seu grupo de professores, por exemplo, naquele grupo precisa incentivar mais a internacionalização, outro gestor em outro grupo vai priorizar a produção. Então depende das características do grupo você identifica os pontos fracos e fortes e trabalha ali.

Entrevistadora: No seu grupo, nesse grupo com qual você trabalha, tem alguma coisa que você... 
Coordenador A - PUCRS: No nosso caso, por exemplo, como a gente está no inicio desse processo de nota 6, aparece para gente como algo prioritário o reforço, a ampliação e a consolidação dos convênios internacionais. E a gente está apostando muito nisso porque isso é o que diferencia os programa 6 e 7 dos programas 5 , por exemplo, então como a gente é um 6 recente a gente está atento para consolidar isso.

Entrevistadora: Teve algum tipo de formação ou preparação para atuar como gestor de programa?

Coordenador A - PUCRS: Isso é uma grande lacuna e eu acho que deve ser em todo lugar.

Entrevistadora: Eu estou perguntando... (risos).

Coordenador A - PUCRS: Olha, isso é incrível, é abrupto, é uma passagem totalmente abrupta, você chega aqui, você é uma professora dentro da sua salinha, fazendo suas coisinhas, tudo direitinho, e de um dia para o outro você chega aqui e tem que sair decidindo, entendendo das portarias, sei lá. É um monte de informação e você tem que saber.

Entrevistadora: E mesmo nos cursos, até mesmo, porque, por exemplo, a minha formação é educação com habilitação em administração, pós-graduação em administração escolar e... Mas sobre a pós-graduação pouco é falado, a pósgraduação é uma área pouco, inclusive, estudada. Mas o foco é sempre...

Coordenador A - PUCRS: Essa é uma formação em serviço. Você entra, claro, o que a gente tem? Para não te dizer... Eu acho abrupta, acho difícil, acho que outros gestores devem ter sentido isso também, mas o que nós temos para nos apoiar? Nós temos algumas coisas, assim, a gente tem uma pró-reitoria de pesquisa que nos apoia bastante, por exemplo, nós temos uma comissão agora na pró-reitoria de pesquisa que nos apoia no relatório Capes, então a gente pode marcar uma hora e levar as duvidas, quando o relatório está pronto, inclusive nós temos uma data interna anterior a data de envio para Capes, o relatório vai para essa, para esse setor dentro da pró-reitoria de pesquisa. É lido e a gente tem a chance de ter um feedback, de poder melhorar, então isso é muito importante, deixa a gente mais seguro na gestão, entendeu? Por exemplo, a gente tem as formações que a própria PUC oferece, toda essa discussão de ética na pesquisa que agora está aparecendo e que influencia diretamente sobre a gestão do Programa. A gente tem várias iniciativas da nossa pró-reitoria de formação, de seminários voltados, isso eu acho que é importante. Então, assim, de fato a gente tem uma formação aqui dentro que vai mudando ao longo do tempo, uma formação continuada, vamos dizer assim, para os gestores, para os professores, que é uma instância interessante, agora, digamos, essa rotina do coordenador, tipo assim, não tem.

Entrevistadora: Quando você for coordenador, são os seguintes problemas...

Coordenador A - PUCRS: Sei lá, "tem uma capacitação especifica antes de assumir", entendeu, não tem. 
Entrevistadora: Aqui você já falou um pouco: O que considera que poderia ser feito pelas instituições, Universidades...

Coordenador A - PUCRS: Eu acho que aonde também se dá essa formação, um pouco, mas não é o suficiente, é na comissão coordenadora. Em geral, eu era da comissão coordenadora, em geral o coordenador sai da comissão coordenadora. Então, enquanto comissão coordenadora, você vai já se aproximando desse cotidiano da gestão.

Entrevistadora: Considera que poderia ser feito, o que considera que poderia ser feito pelas Universidades, acho que aqui já tem algumas iniciativas, pela Capes, pelo MEC para contribuir com o trabalho dos coordenadores de programa? Em relação a Capes, assim, sente algum amparo da Capes em relação ao trabalho de coordenador?

Coordenador A - PUCRS: A Capes também faz periodicamente seminários e reuniões com os coordenadores, então eu acho que sim, até porque a gente não teria tempo, entendeu? Se a gente fizer muita coisa e a Capes resolve fazer um monte de... A Capes já nos chama periodicamente para seminários e tal. E outra coisa que tá, que eu acho que também é um apoio, é que a Capes sinalizou com a possibilidade de uma bolsa de pesquisa para coordenador, que eu acho justo, uma vez que, por exemplo, aqui na PUC, que acho, não sei como é em outras Universidades, a gente não tem nenhuma mudança funcional em termos de salário quando assume o papel da coordenação, não há. Em geral, a gente tem uma quantidade de horas na planilha que eu acho muito menor do que efetivamente consome, eu acho que eu tenho 8 horas de planilha por dia para ser coordenadora do Programa. Eu gasto muito, muito, muito mais que isso.

Entrevistadora: Essa era uma pergunta que eu ia colocar, que estava mais adiante, mas você já respondeu, se tinha alguma gratificação porque a minha hipótese é que... Era de que nas Universidades particulares talvez houvesse.

Coordenador A - PUCRS: Eu já trabalhei em duas, fui coordenadora nas duas, de programa, e nenhuma delas tem, teve.

Entrevistadora: Porque na pública também não tem não.

Coordenador A - PUCRS: Tem, tem o SG em alguns lugares.

Entrevistadora: Depende, quando tem disponibilidade, por exemplo, lá na Fiocruz no Programa não tem, no caso. Então é mais difícil e o que eu acho um absurdo porque é tanto trabalho, complexo, uma responsabilidade.

Coordenador A - PUCRS: Inclusive te custa, o ônus da coordenação é aquela história do Bourdieu, você perde capital cientifico, entendeu? Você vai para o capital burocrático e isso é um prejuízo para carreira de um pesquisador.

Entrevistadora: Qual seria a parte mais interessante de estar coordenando um programa de pós-graduação, qual é o ganho disso? 
Coordenador A - PUCRS: Olha, eu acho que essas funções a gente assume por necessidade e convocação, pelo menos do meu ponto de vista. Eu não me candidatei e nem batalhei e nem era esse o intuito (risos), justamente por isso, que eu acho essa coisa do capital burocrático, enfim, me identifico como pesquisadora, não me interesso fazer carreira burocrática. Eu acho que é mais uma necessidade, é um momento que se configura como, "este é o teu momento de fazer isso". Você participa de um grupo e você tem que assumir. Acho que é mais uma tarefa do que um ônus, do que um bônus, na verdade. Claro, o que é a parte que seria, digamos assim, a "moeda de troca" que as pessoas te chamam para te convencer a pegar a tarefa é, enfim, você tem, você ganha uma circulação pelas instancias que fazem a política. Você está mais perto de um circuito de tomada de decisão que faz a política da pós-graduação no Brasil. Participar do Forpred, que é o Fórum de Coordenadores de Programas, essas instancias da Anped, participar das reuniões da Capes, onde você tem possibilidade também de interferir em alguma medida. Isso, digamos assim, acho que é uma instancia de poder e de prestigio que seria, digamos, o aspecto que quem está em uma posição dessas deve se beneficiar porque a única coisa porque como compensação, digamos assim, a essa... Você sabe que você vai ter menos tempo para pesquisa, para orientar, para fazer artigos e tal.

Entrevistadora: Acho que você já falou um pouco, assim, o provimento ao cargo, como que é? É uma indicação...

Coordenador A - PUCRS: Então, aqui na PUC ela é uma indicação do diretor da faculdade, da unidade acadêmica e passa, é uma indicação ao pró-reitor e as instâncias de pró-reitoria e reitoria...

Entrevistadora: Desculpa, me perdi. É indicação de que?

Coordenador A - PUCRS: É indicação do diretor da Faculdade porque aqui na PUC, como em muitas Universidades, acho que até talvez na Pública, a unidade administrativa não é na pós-graduação, a unidade acadêmica administrativa é a Faculdade de Educação. Então o diretor da Faculdade de Educação, ele está em uma posição de decisão mais importante do que o coordenador da pósgraduação. Então, ele é que tem o poder de indicar o coordenador da pósgraduação, é ele quem indica. Ele indica para quem? Ele indica para o colegiado, digamos, da Universidade, que são as prós-reitorias e a reitoria, e o colegiado, que, digamos, de gestão da Universidade é que reitera essa indicação ou não. É uma negociação dentro da... Não é eleito, não é eleito pelos colegas...

Entrevistadora: Em muitos lugares, até mesmo nas públicas às vezes não é eleição também. Estrutura de apoio à coordenação. Então, a primeira estrutura que eu coloquei aqui seria a comissão coordenadora, você considera mesmo que a comissão é um apoio...

Coordenador A - PUCRS: É um apoio efetivamente, é sim.

Entrevistadora: E essa comissão, eu cheguei a ler o regulamento, mas... 
Coordenador A - PUCRS: Inclusive essa comissão a gente ontem, olhando a página da PUC eu pedi para atualizar, estava velha. A gente mudou a comissão, então se você entrar hoje possivelmente já está diferente do que você viu antes.

Entrevistadora: Quantos docentes são eleitos nessa comissão?

Coordenador A - PUCRS: A gente não faz eleição, é assim: Qual é a composição estrutural? Nós temos três linhas de pesquisa dentro do Programa e cada linha indica o seu representante. Nesse sentido há uma eleição. É indicação. Cada linha de pesquisa indica seu representante na comissão coordenadora, então são três pessoas que representam três linhas e depois os membros natos da comissão são: o coordenador do Programa e o diretor da Faculdade. É assim que se compõem.

Entrevistadora: E tem alunos?

Coordenador A - PUCRS: E tem o representante discente. Isso mesmo.

Entrevistadora: O aluno representante discente é um para mestrandos e doutorandos?

Coordenador A - PUCRS: É um só para todos os alunos.

Entrevistadora: Eleito, esse é eleito?

Coordenador A - PUCRS: Eleito pelos alunos. Indicado pelos alunos.

Entrevistadora: Acho que a gente já falou da Capes, do tipo de apoio. Coordenador adjunto tem essa figura?

Coordenador A - PUCRS: Nós não temos aqui essa função.

Entrevistadora: É bom, até alguém começar a chorar um pouquinho (risos).

Coordenador A - PUCRS: O que a gente faz quando a gente precisa, sei lá, tem duas reuniões ao mesmo tempo, é um membro da comissão coordenadora que representa o coordenador quando ele não está presente ou não pode atender duas atividades ao mesmo tempo.

Entrevistadora: A secretaria acadêmica ela é do Programa ou ela é da Universidade, como é que é esse apoio de secretaria?

Coordenador A - PUCRS: Nós temos. Eu acho bem razoável, aqui nós temos três secretárias, duas em tempo integral e uma em meio tempo, só para o Programa. Aqui a gente faz a gestão do Programa e dos cursos de especialização, que são as pós-graduações lato sensu.

Entrevistadora: E quantos são? 
Coordenador A - PUCRS: São muitos, deve ter agora uns quatro, cinco cursos de especialização lato sensu.

Entrevistadora: Mas você não fica responsável por esses cursos não?

Coordenador A - PUCRS: Não diretamente.

Entrevistadora: Na PUC do Rio tem uma diferenciação: tem a parte de secretaria geral, que aonde, por exemplo, a gente faz a matricula online, diplomas e tal; e a secretaria do Programa que cuida de partes especificas, assim, dos alunos. Aqui tem essa divisão também ou elas cuidam de tudo, inclusive do sistema de registro acadêmico?

Coordenador A - PUCRS: Elas cuidam de tudo, o que a gente tem é uma secretaria da graduação e uma secretaria da pós-graduação. Mas a secretaria da pós-graduação cuida de registro acadêmico, emissão de certificados, cadastramento dos bolsistas, ajudar a gente a fazer a planilha de professores, é tudo.

Entrevistadora: Além do regulamento do Programa, você já mencionou, tem outros documentos que colaboram? Porque, assim, meu entendimento é que tendo um documento, às vezes, que norteia, isso também é uma estrutura de apoio de certa forma. Tem já muita coisa encaminhada?

Coordenador A - PUCRS: A gente tem o regulamento do Programa, mas tem várias situações em que vão ficando omissas porque a responsabilidade vai se complexificando e aí vai ficando, falta naquilo depois, no regulamento. E a gente tem todos os documentos da Capes, que é uma, um conjunto enorme de documentos, entendeu? Que não estão muito claros, mas que incidem diretamente sobre a gestão, então se você tem bolsa PNPD, você tem que dominar o edital PNPD, você tem o PEC-PG, tem que saber o que é o PEC-PG, como é que faz para inserir alunos estrangeiros aqui. Então na verdade é uma diversidade de documentos que a gente tem que manejar, o Prosup, o edital Prosup para a gente poder implementar bolsas a gente tem que dominar bem o Prosup. Agora é um novo Prosup que saiu agora, então, digamos, há uma infinidade de documentos, não só da PUC, mas da Capes e do CNPq.

Entrevistadora: Voltando um pouquinho, você falou: o regulamento deixa situações omissas. Diante dessas situações omissas, o Programa normalmente faz portarias ou...

Coordenador A - PUCRS: Exatamente, aí a gente faz portaria, aí a comissão coordenadora propõe, por exemplo, uma regulamentação.

Entrevistadora: Posso ter acesso a essa, por exemplo, as portarias do Programa? Porque, assim, eu entrei no site...

Coordenador A - PUCRS: Nós temos essas, na verdade não são muitas. Então temos essa que definiu a produção dos alunos. E depois, me deixa pensar um exemplo de portaria que a gente tenha feito, assim, mais importante, que não seja letrinhas muito miúdas. O importante acho que foi essa, por exemplo, a 
questão da bolsa, mas a questão das bolsas a gente vai bem colado nas orientações do edital, aí, não, a gente não tem uma portaria, o que a gente tem, por exemplo, esses critérios de avaliação de bolsista que a gente considera, alguns são nossos e isso gerou uma planilha, que não é uma portaria, é uma planilha, um documento de gestão, uma planilha, que acho que está no site ou pelo menos deveria estar que o próprio bolsista recebe para orientar o relatório que ele faz. Então tem lá: Quantos eventos você participou promovidos pelo Programa neste ano? Por quê? Porque a gente acha que bolsista deve participar das atividades do Programa. Então isso é uma planilha, digamos assim, com critérios de avaliação do bolsista. Isso a gente fez com a comissão coordenadora e aprovou. Não é uma portaria, é uma planilha. Por exemplo, um caso que é omisso no nosso... Por exemplo, essa semana estava vendo no nosso regulamento, o aluno tem tempo máximo para defender, mas não tem tempo mínimo. Então, por exemplo, eu tive uma demanda de um aluno que está fazendo doutorado: "Mas se eu quiser defender no segundo ano ao invés de quatro, posso?". Eu falei: "Não sei”. Aí a gente até na próxima reunião de comissão coordenadora eu vou levar essa questão para a gente ver se interessa fazer uma portaria definindo tempo mínimo. Porque eu sei que tem Universidades que tem tempo mínimo.

Entrevistadora: É, eu nunca... Engraço que isso eu nunca ouvi falar. Já ouvi falar de pessoas que defendem muito rapidamente, que já tem encaminhado alguma coisa, um caso a se pensar.

Coordenador A - PUCRS: Para o programa que conheço mais lá, que a gente colabora, eles têm tempo mínimo. E não é único e é em nível de uma regulamentação, um dos programas no regulamento geral da reitoria.

Entrevistadora: Queria que você pensasse, ah, porque também a lógica da Universidade particular pode ser outra: Por que o tempo mínimo? Porque quando a gente pensa na pública, parece que só tem vantagem uma pessoa...

Coordenador A - PUCRS: Terminar antes. Mas, por exemplo, você também, a gente tem que qualificar. Você tem que ter um tempo mínimo que seja para estabelecer um projeto, qualificar e concluir, então...

Entrevistadora: Bom, só mais uma pergunta, em relação à infraestrutura do Programa. Você considera adequada? Precisa ampliar, melhorar alguma coisa? A infraestrutura física mesmo.

Coordenador A - PUCRS: Olha, eu acho a infraestrutura física nossa, ela é boa. Todo mundo tem sala individual, climatizada, computadores. Eu acho que o que nós precisamos aqui é a reforma do nosso prédio. Isso a PUC já reconhece porque a gente tem, sei lá, situações como, esse prédio é um prédio antigo e tem problemas, por exemplo, de inundação. A gente tem alguns problemas, até agora a gente fez uma limpeza de calhas e tal, uma recuperação, mas quando chove muito tem salas, algumas salas que estão nas pontas e tem problema de infiltração. Então, assim, coisas físicas, de manutenção do prédio que a gente já comunicou e que tem um plano de reforma. Mas fora isso, que seria a manutenção do prédio, eu acho que a gente tem, as salas são adequadas, tem um 
numero suficiente, a gente tem equipamentos, tem salas que tem equipamentos permanentes de multimídia, é razoável, eu acho que, claro, sempre pode ser melhorado. É razoável, não acho precário não.

Entrevistadora: Comparando lá com a nossa situação. A briga por espaço, uma sala para cada professor...

Coordenador A - PUCRS: A gente tem uma sala só para bolsista de pósgraduação, a gente tem uma sala só com muitos terminais de computadores para bolsistas de graduação, iniciação científica. A gente tem uma biblioteca fantástica, uma das melhores da região aqui. Eu acho que a gente tem sim uma boa infraestrutura.

Entrevistadora: E aí um pouquinho sobre os documentos relativos à politica de pós-graduação de forma mais geral. Sobre o plano nacional de pós-graduação: Você já teve acesso? Conhece?

Coordenador A - PUCRS: Conheço, tive acesso.

Entrevistadora: Você acha que as diretrizes do plano interferem na coordenação do Programa, diretamente? Ou não? É só uma coisa indireta?

Coordenador A - PUCRS: Então, a gente teve até uma reunião justamente na Capes em novembro do ano passado e algumas dessas questões foram discutidas, o que... Eu acho que sim, são metas de longo prazo, entendeu? Não são metas que incidem hoje, diretamente, quer dizer, são metas de longo prazo que eu acho que dão direções para gestão. Então, tópicos como interdisciplinaridade, inovação, que eu acho que são interessantes e nós temos uma pró-reitoria muito afinada com essas, inclusive com a elaboração desse plano. O nosso pró-reitor, professor Aldir, ele participou na elaboração do plano, então, para nós isso é interessante porque a gente tenha também aqui nas reuniões como, por exemplo, essas reuniões eventualmente que a gente tem com a pró-reitoria para discutir esses documentos. Então a gente se sente informado e, digamos, isso não fica em uma responsabilidade individual do gestor, mas ela é compartilhada com a pró-reitoria de pesquisa. Então eu acho que é interessante, incide sim, mas é dentro de um projeto que é da Universidade também, não é só de cada programa.

Entrevistadora: O documento de Área da Capes, ele influencia?

Coordenador A - PUCRS: A gente lê, é claro, com muita atenção esse documento de Área. Tenta se adequar...

Entrevistadora: Ele influencia mais do que o plano.

Coordenador A - PUCRS: Ele é mais, ele é voltado para isso. O plano é outro nível, uma política pública de longo prazo. O documento incide diretamente sobre o que você vai fazer naquele ano, naquele triênio. 
Entrevistadora: Demandas, principais demandas do corpo docente em relação ao coordenador do Programa, assim, o que você sente que o corpo docente espera do coordenador, se há uma coisa única, ou não...

Coordenador A - PUCRS: Olha, eu acho que o corpo docente espera que o coordenador coordene (risos), entendeu? Porque esse é o papel, coordene as políticas e as demandas de um modo a deixar os professores trabalharem, entendeu? Era a minha expectativa também quando era professora (risos). Acho que a coordenação ela tem que amparar o professor, ela tem também que dar suporte para o professor, sabe? De alguma maneira eu acho que a coordenação ela tem que atuar também, um pouco na defesa do professor. Preservar o professor no caso de uma série de coisas, para ele produzir legal, para ele poder...

Entrevistadora: O que você está falando talvez tenha haver com a outra pergunta, que seria: Quais as dificuldades que você observa em relação aos, que os docentes enfrentam na realização do seu trabalho de pós-graduação?

Coordenador A - PUCRS: A multiplicidade de tarefas. São muitas tarefas porque, por exemplo, mesmo que a gente diga, "ah, a política de avaliação é falha porque não criou linhas de inserção social". Ok, agora vai dar para o professor fazer trabalho de ponta, com alta qualidade científica, publicar em periódico internacional, participar de, e ao mesmo tempo fazer trabalhos aplicados na escola básica, ir para a favela, ir para a Vila Fátima...? Você acha que a mesma pessoa vai conseguir fazer tudo isso? Não vai! Então, o que eu acho que todos nós estamos submetidos a um modelo de Universidade ideal, entendeu, que ele é pouco, que ele não é humano, que ele não é uma medida humana, ele é mais de uma perspectiva idealizada. Outro problema desse ideal que eu acho que eu sinto uma culpa imensa é que ele se traduz como, você tem que atingir tudo isso em um perfil de um único professor. Ele tem uma distribuição de trabalho, você tem professor cujo perfil é mais extensão, inserção social, outro que é produção cientifica de alto nível, o outro... Eu acho que o problema é que esse modelo ele deveria ser um modelo para a Universidade, mas poderia haver uma tolerância, uma compreensão de que dentro de um programa você tem perfis diferentes, mais adequados, pouca inserção social, para a produção científica, outro para a divulgação científica, aonde você não precisa cobrar tudo de todos. Todos tem que ser excelentes em tudo, da produção de alto nível ao trabalho de inserção social. É isso que não é humano, isso não é uma medida humana...

Entrevistadora: É para Super-Homem.

Coordenador A - PUCRS: Está idealizado, não é para uma pessoa real, de verdade. Por isso que eu acho também que o coordenador, ele tem que ser, ele não pode ser ingênuo, de entender essas políticas como algo que você pode traduzir imediatamente e cobrando, que você mata a sua equipe de stress, entendeu. Ninguém produz nada, fica todo mundo paralisado, adoece, pede demissão, vai fazer outra coisa na vida, as pessoas continuam sendo humanas, o dia continua tendo 24 horas, todo mundo continua tendo uma vida independente do trabalho, que é justo. Então, assim, a gente tem que traduzir, digamos, esse 
ideal. Em qualquer programa esse ideal vai se adequar a uma realidade humana, eu acho. Então, aí...

Entrevistadora: Mais uma perguntinha: Quais as maiores dificuldades dos discentes em relação aos seus estudos?

Coordenador A - PUCRS: Atualmente para nós é o trabalho. As pessoas trabalham e as pessoas como nós, eu acho que isso é uma questão maior, assim, do nosso tempo que a gente está vivendo, há uma... Eu acho que isso é uma questão do mundo do trabalho. Isso que a gente está falando, de um modelo idealizado, ele está na academia, mas ele também não está só na academia. Então, assim, todo mundo faz mil coisas. Acelerou o tempo, a internet, os meios eletrônicos puseram as pessoas na frente de muitas coisas ao mesmo tempo, essa coisa multitarefa. Eu acho que isso também atinge não só os professores, atinge os nossos alunos que também são professores. Que também estão nas Universidades e que também estão vivendo a mesma coisa que a gente. Então eu acho que esse é o problema hoje para você formar pesquisador de alto nível com pessoas que fazem mil coisas ao mesmo tempo.

Entrevistadora: (Agradecimentos finais). 
Anexo 3 - Quadro de pesos por área do conhecimento e nível Proap

\begin{tabular}{|c|c|c|}
\hline \multirow{2}{*}{ Grande Área } & \multicolumn{2}{|c|}{ PESO } \\
\hline & Mestrado & Doutorado \\
\hline $\begin{array}{l}\text { Ciências Exatas e da Terra } \\
\text { Exceções: }\end{array}$ & 4 & 5 \\
\hline Matemática & 3 & 4 \\
\hline Estatística & 3 & 4 \\
\hline Ciências Biológicas & 4 & 5 \\
\hline Engenharias & 4 & 5 \\
\hline Ciências da Saúde & 4 & 5 \\
\hline Exceções: & & \\
\hline Educação Física & 3 & 4 \\
\hline Enfermagem & 3 & 4 \\
\hline Ciências Agrárias & 4 & 5 \\
\hline Ciências Sociais Aplicadas & 2 & 3 \\
\hline Arquitetura & 3 & 4 \\
\hline Comunicação & 3 & 4 \\
\hline Ciências Humanas & 2 & 3 \\
\hline Exceção: & & \\
\hline Psicologia & 3 & 4 \\
\hline Antropologia & 4 & 5 \\
\hline Geografia & 4 & 5 \\
\hline Letras e Linguística & 2 & 3 \\
\hline Artes & 3 & 4 \\
\hline Multidisciplinar & 3 & 4 \\
\hline Ensino de Ciências & 2 & 3 \\
\hline
\end{tabular}

Fonte: Portaria Proap nº4, de 24 de março de 2010. 